\title{
Opowiadania zebrane
}

Księga z okazji Jubileuszu 70. urodzin

Profesora Andrzeja Sopoćko 



\title{
Opowiadania
} zebrane

\section{Księga z okazji Jubileuszu 70. urodzin Profesora Andrzeja Sopoćko}

\author{
Redakcja \\ Renata Karkowska \\ Katarzyna Niewińska
}

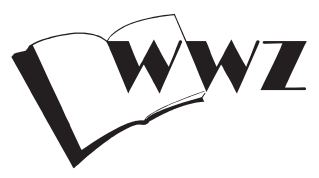

Wydawnictwo Naukowe Wydziału Zarzadzania Uniwersytetu Warszawskiego

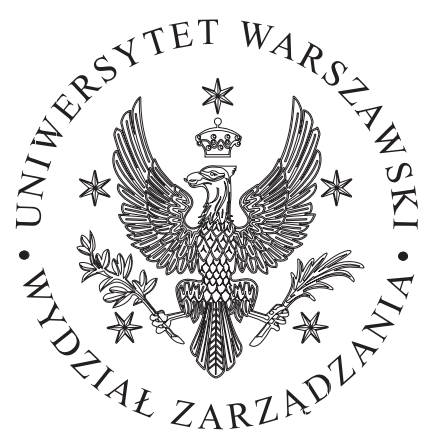


Opracowanie językowe i korekta

Anna Goryńska

\section{Projekt okładki}

Agnieszka Miłaszewicz

(C) Copyright by Wydawnictwo Naukowe Wydziału Zarządzania Uniwersytetu Warszawskiego, Warszawa 2018

Wszelkie prawa zastrzeżone. Kopiowanie, przedrukowywanie i rozpowszechnianie całości lub fragmentów bez uzyskania pozwolenia zabronione.

ISBN 978-83-65402-89-9

e-ISBN 978-83-65402-90-5

DOI: 10.7172/ 978-83-65402-90-5.2018.wwz.7

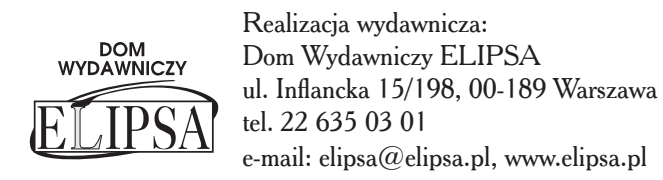




\section{Spis treści}

Renata Karkowska, Katarzyna Niewińska

Wstęp........................................ 13

Najważniejsi w życiu: rodzina i...

Przygody z Ojcem - historie widziane oczami dzieci

- Anny i Bartlomieja ............................... 19

Nauka i środowisko akademickie

Alojzy Z. Nowak

Dziekan o Jubilacie .............................. 31

Barbara Czarniawska

Wspomnienia ze Szwecji... ........................ 34

Jan Czekaj, Stanisław Owsiak

Andrzej Sopoćko: przyjaciel, uczony, dziatacz państwowy ........ 37

Jan Gajda

Gajda o Sopoćko ............................... 52 
Beata Glinka

Pokój obok.............................. 54

Ewa Krakowińska

Moje rozmowy z Profesorem.................. 57

Tomek Ochinowski

Profesorski Lubileusz z naukowemy przypisamy........... 61

Maciej Ramus

Kilka lekcji Andrzeja Sopoćko................... 68

Kazimierz Ryć

Z Andrzejem Sopoćko na eksport ................ 71

Jerzy Wierzbiński

Rzadki talent do pisania prosto o bardzo zawitych

zagadnieniach .

\section{Papier i pióro}

Sebastian Skuza

List gratulacyjny z Ministerstwa Nauki i Szkolnictwa Wyższego . . . . 79

Jerzy Jagodziński

Andrzej oczami redakcji ................... 80

Grzegorz Jędrzejczak

Andrzej Sopoćko - ekonomista myślący................ 85

Jerzy Żyżyński

Definicja kluczem do zrozumienia ................. 90 


\section{Ekonomia, świat wielkich finansów i polityki}

Teresa Czerwińska

List gratulacyjny od Ministra Finansów................ 101

Marta Postuła

Cztery miesiquce wspólnej przygody na Świętokrzyskiej . . . . . . . . . . 102

Andrzej Palczewski

Od Inter-Risk do Big Data . . . . . . . . . . . . . . . . . 108

Bogdan Szafrański

Inauguracja GPW $w$ Warszawie - $w$ Kalifornii............. 116

Stanisław Nowak, Krystyna Rychlica

Izba Gospodarcza Ubezpieczeń i Obstugi Ryzyka

o Profesorze Andrzeju Sopoćko . . . . . . . . . . . . . . . . . . . 126

\section{Pokolenia wychowane przez Profesora Andrzeja Sopoćko}

Renata Karkowska, Paweł Karkowski

Inteligencja $i$ sentymentalizm . . . . . . . . . . . . . . . . . 135

Andrzej Kurnicki

Café and capital - rozmowy przy kawie ............... 141

Katarzyna Niewińska

Dla ,ojca naukowego" ...................... 148

Anna Popiołek

Profesor nie tylko od finansów. . . . . . . . . . . . . . 152

Andrzej Rutkowski

O Profesorze Andrzeju Sopoćko . . . . . . . . . . . . . . . . 157 
Patrycja Chodnicka-Jaworska

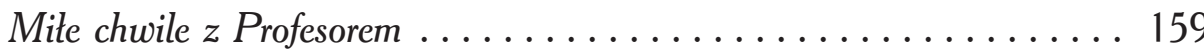

Jakub Górka

Profesor Andrzej Sopoćko w moich oczach - profesor i człowiek

o wielu talentach $i$ zainteresowaniach. .................. 162

Piotr Jaworski

Profesor Andrzej Sopoćko - kilka stów . . . . . . . . . . . . . . . . 165

Waldemar Kozioł

Moje spotkania z Profesorem Andrzejem Sopoćko ............. 167

Piotr Sokół

Trzy zdarzenia ...................... 170

Wspomnienia, idee, marzenia...

Monika Kostera

Wino $z$ Ważka ............................ 175

Leszek Jerzy Jasiński

Kraina Ekonomicznej Szczęśliwości................... 180

Paweł Kozłowski

Zawsze............................. 193

Andrzej w świetle reflektorów

Marek Monkiewicz

Andrzej $-z \dot{z}$ artobliwym dystansem do świata . . . . . . . . . . 201

Robert Pietrusiński

Dla Andrzeja. Dla Artysty . . . . . . . . . . . . . . . . . . . . . . 204 
Tadeusz Winkler-Drews

Koloryt Andrzeja ....................... 210

Julita Wójcik

Killka (?) twarzy Andrzeja S. . . . . . . . . . . . . . . . . . . . 212

Scenariusze autorstwa Profesora Andrzeja Sopoćko

Kabaret 2010 rok ....................... 217

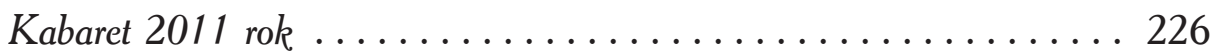

Kabaret 2013 rok ....................... 241

Kabaret 2014 rok ......................... 249

Kabaret 2016 rok ....................... 256 



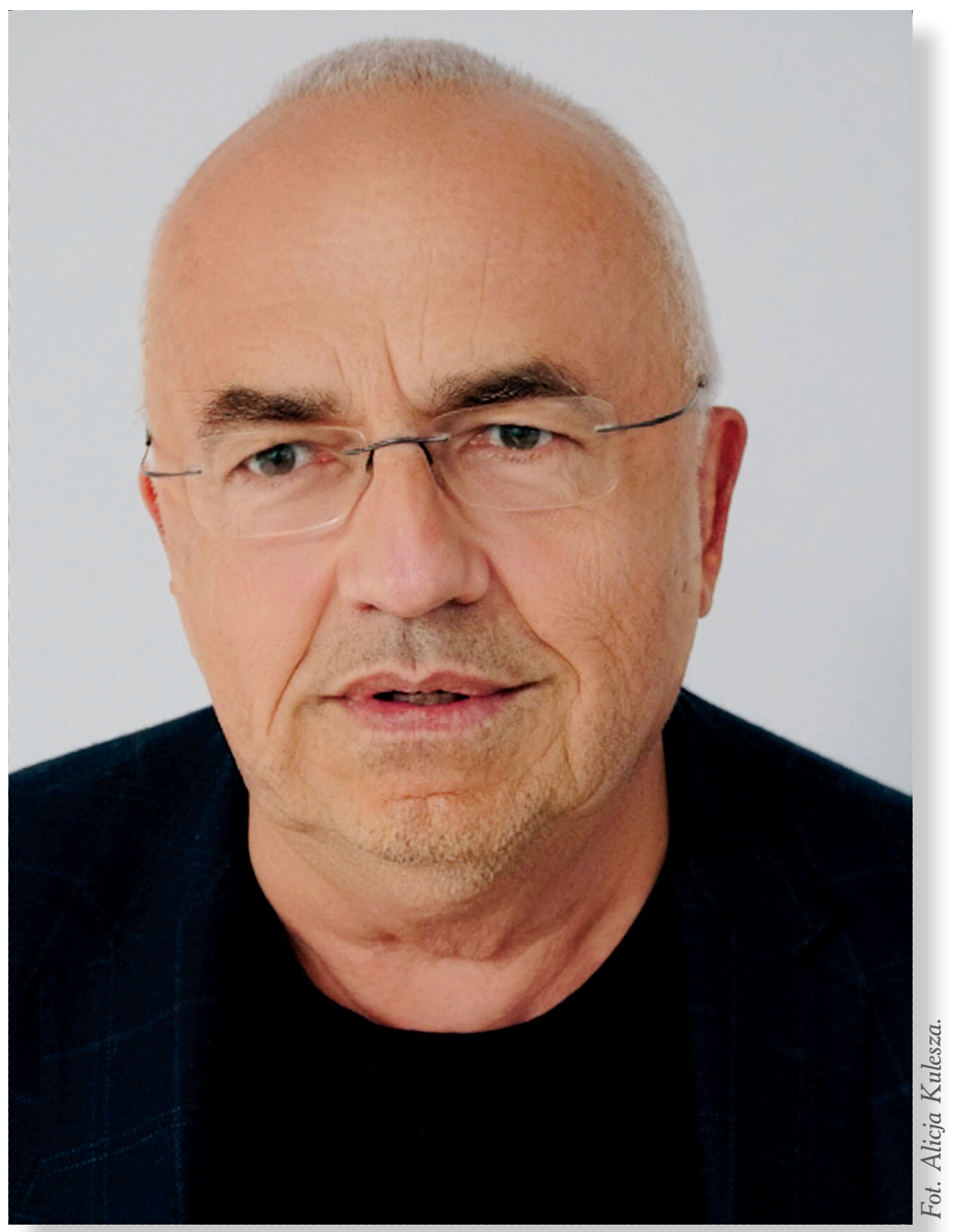

Profesor Andrzej Sopoćko 



\section{Wstęp}

Sanowny Panie Profesorze,

$\mathcal{W}_{\mathrm{w} \text { rocznicę Twoich siedemdziesiątych urodzin mamy przyjemność }}$ podarować $\mathrm{Ci}$ zbiór wspomnien i życzeń od osób najblizzszych Tobie: rodziny, przyjaciół, kolegów i wychowanków.

Kierowani porywem serca i szacunkiem do Ciebie jako Ojca, swoje słowa kierują $\mathrm{Ci}$, których kochasz najbardziej - córka Anna i syn Bartłomiej. Dla nich dzieciństwo zawsze będzie pachnieć wakacjami, spędzonymi w gronie rodzinnym w Warszawie, nad morzem czy w Sobolewie. Honorowe miejsce w księdze zajmują oczywiście Wasze psy: Bruno, Moran i Szon.

Jubileusz siedemdziesiątych urodzin zbiega się z rocznicą czterdziestu lat Twojej pracy akademickiej na Wydziale Zarządzania Uniwersytetu Warszawskiego. To piękny czas do podsumowań i wspomnień dla Tych, którzy razem z Tobą poszukują rozwiązań w zawilym świecie nauki. Dlatego z największą przyjemnością swój obraz Andrzeja jako przyjaciela i kolegi przekazują profesorowie: Dziekan Wydziału Zarządzania UW Alojzy Z. Nowak, Barbara Czarniawska, Jan Czekaj, Stanisław Owsiak, Jan Gajda, Beata Glinka, Ewa Krakowińska, Tomasz Ochinowski, Maciej Ramus, Kazimierz Ryć oraz Jerzy Wierzbiński. Sebastian Skuza, Podsekretarz Stanu w Ministerstwie Nauki i Szkolnictwa 
Wyższego, ma przyjemność złożyć Ci list gratulacyjny za Twój wkład w polską i światową naukę.

Przez lata mogliśmy cieszyć się Twoim talentem pisarskim, co zgodnie podkreślają w swoich tekstach: redaktor Wydawnictwa Naukowego Wydziału Zarządzania UW Jerzy Jagodziński, Grzegorz Jędrzejczak, oraz Jerzy Żyżyński.

W Twoim sercu zawsze drzemała dusza romantyczna. Dlatego Monika Kostera z okazji Twoich 70. urodzin napisała wiersz - pełen lirycznych wspomnień i uniesień. Z Lechem Jasińskim przeniesiemy się na Wyspę Ekonomicznej Szczęśliwości, gdzie czekają Cię nowe przygody i doświadczenia. A razem z Pawłem Kozłowskim wybierzesz się w tajemniczą podróż w nieznane.

Ekonomia i świat polityki są istotną częścią Twojego życia. W dowód uznania Minister Finansów, Teresa Czerwińska napisała list gratulacyjny. Marta Postuła przytacza wspomnienia z czasów, kiedy pełniłeś funkcję Podsekretarza Stanu w Ministerstwie Finansów i przywołuje Twój obraz jako osoby, która w tym czasie poświęciła niemal wszystko dla pracy i dla swojego kraju, aby tworzyć zmiany sprzyjające rozwojowi państwa. Andrzej Palczewski opowiada, jak powstawała Wasza wspólna firma Inter-Risk, w ramach której opracowywane były prognozy stóp procentowych i analizy ryzyka inwestycyjnego. Twój pierwszy asystent Bogdan Szafrański, wspomina, że nie zna nikogo związanego z rynkiem kapitałowym, kto nie miałby do czynienia z Twoimi książkami. Krystyna Rychlica wraz ze Stanisławem Nowakiem wracają pamięcią do chwili, kiedy kilkanaście lat temu pomagałeś im w tworzeniu Izby Gospodarczej Ubezpieczeń i Obsługi Ryzyka oraz cieszą się, że wciąż prężnie działasz na jej rzecz.

Twoi wychowankowie pierwsze spotkania z Tobą odbyli na wykładach z rynków kapitałowych. Większość z nich odbierała wtedy Ciebie jako surowego profesora, który cierpliwie i w bardzo przystępny sposób tłumaczył trudne zagadnienia finansowe, wplatając w treści wykładów dowcipy i niebanalne anegdoty. Inspirujesz i uczysz nas przy różnych 
okazjach: na wspólnych konferencjach, seminariach, będąc naszym promotorem, mentorem i wsparciem w pracy naukowej. Na swoim koncie masz całą rzeszę studentów oraz ośmiu doktorantów, którzy pisali pod Twoim czujnym okiem prace naukowe. Prywatnie, zawsze możemy liczyć na Twoją radę, pomoc i motywację. Ponizzej znajdziesz wspomnienia Twoich doktorantów: Renaty i Pawła Karkowskich, Andrzeja Kurnickiego, Katarzyny Niewińskiej, Anny Popiołek, Andrzeja Rutkowskiego, oraz byłych studentów: Patrycji Chodnickiej-Jaworskiej, Jakuba Górki, Piotra Jaworskiego, Waldemara Kozioła oraz Piotra Sokoła.

W książce znajdują się również przepełnione uśmiechem i żartobliwym akcentem teksty: Marka Monkiewicza, Roberta Pietrusińskiego, Tadeusza Winklera-Drewsa oraz Julity Wójcik. To z nimi niejednokrotnie podejmowaliście dyskusję okraszoną dobrym dowcipem.

Zwieńczeniem Twojej artystycznej twórczości jest unikatowa kolekcja scenariuszy kabaretów, których mieliśmy okazję wysłuchiwać podczas konferencji wydziałowych.

W rocznicę Twoich siedemdziesiątych urodzin pragniemy $\mathrm{Ci}$ życzyć przede wszystkim dużo zdrowia, spełnienia wszystkich marzeń i celów, dalszej owocnej pracy naukowej i dydaktycznej, kolejnych wychowanków oraz następnych wspaniałych jubileuszy.

Renata Karkowska

Katarzyna Niewińska 

Najważniejsi $w$ życiu:
rodzina $i .$. 



\section{Przygody z Ojcem}

- historie widziane oczami dzieci - Anny i Barttomieja

asz Tata. Dla Was wszystkich Nauczyciel, Kolega, Mentor, Szef,
dla nas Tata. Życie z naszym Tatą to pasmo różnych ciekawych historii. Mamy w pamięci wiele wspomnień; ciekawych, śmiesznych, czasami wychowawczych. Jako dzieci różnie pamiętamy te historie, ale jedno jest pewne - było kolorowo :)

\section{Oczami Córki}

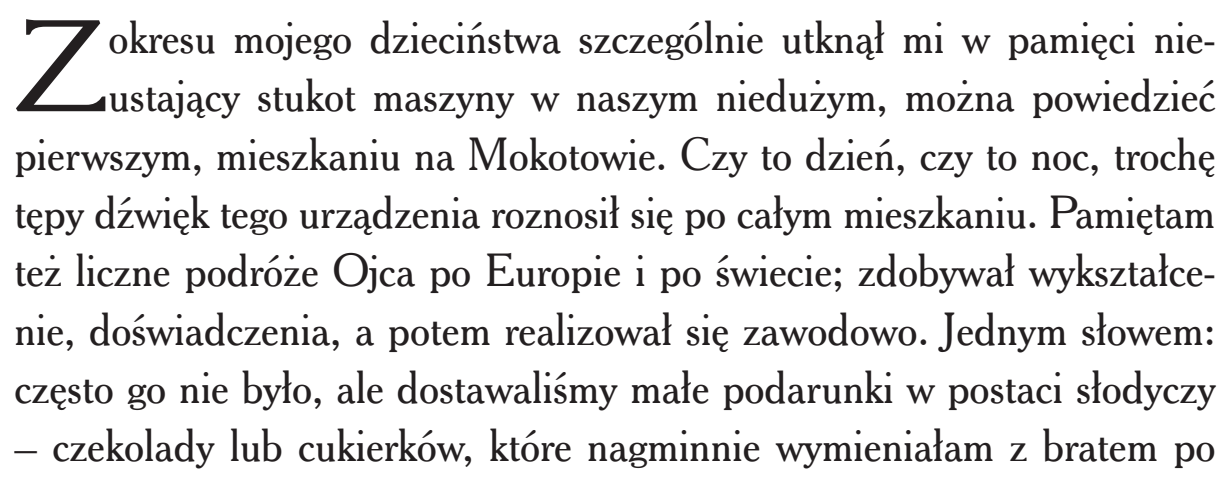


to, aby dostać to, co lubiłam najbardziej, czyli gumowe misie Haribo, w zamian za czekoladę. Mój brat zawsze był fanem czekolady, co bardzo mi pasowało w kontekście wymiany i zdobycia ulubionych „misiów”. Zresztą, w tym obszarze gust do tej pory mi się nie zmienił (:) Pamiętam też małe samochodziki metalowe od Taty, które w tamtych czasach były ogromnym hitem i nieważne, że byłam dziewczynką: taki samochodzik każdy chciał mieć i miałam je ja! Ponieważ dorastałam ze starszym bratem, zadne inne zabawki mnie nie cieszyły jak te małe samochodziki i słodycze, dlatego też Tata dawał obojgu nam takie prezenty.

W okresie całego naszego życia z Ojcem bardzo wyjątkowe było ogromne zamiłowanie do zwierząt i szanowanie ich. Zwierzęta towarzyszą nam w zasadzie od dzieciństwa. Nie zawsze mieszkały z nami, ale zawsze nas otaczały. Nieważne, czy duże czy małe zwierzę, każde, jeśli znalazło się u nas w domu, miało dla siebie kąt, jedzenie i dużą atencję ze strony domowników. Zawsze były psy. Jak miałam 6 lat, Tata przyprowadził małego kundelka. Nazywał się Kubuś i żył z nami prawie 10 lat. Był bardzo uroczym pieskiem, czarnym, lekko podpalanym. Był bardzo z nami zżyty, ale też chodził swoimi ścieżkami w poszukiwaniu nowych przygód, czy to w Warszawie, czy w Sobolewie, gdzie mieszkali moi Dziadkowie ze strony mamy i gdzie często spędzaliśmy wolny czas. Ojciec spędzał z nim dużo czasu, wychodził zawsze na poranne spacery, ale też dyscyplinował mnie i brata, abyśmy też z nim wychodzili; pewnie chodziło o codzienne obowiązki, jakie chciał w nas wpajać. $Z$ reguły nie mieliśmy z tymi spacerami problemu, bo to oznaczało kolejne wyjście na dwór, czyli pretekst do nieodrabiania lekcji...(-) Wszystko, co żywe, nie trwa wiecznie i niestety Kubuś zmarł. Po kilku miesiącach od śmierci Kubusia, którą, jak przypuszczam, Ojciec bardzo przeżywał, zdecydowaliśmy się na kolejnego pieska. Tym razem przyniosłam go ja. Był to owczarek niemiecki, nazwałam go Bruno, i wyrósł na pięknego, dużego psa, z trochę krzywymi przednimi łapkami, ale kto by na to patrzył. Liczyło się, że jest to nasz pies i był pod każdym względem najpięk- 
niejszy. Na początku Bruno, jak to szczeniak, był malutki i uroczy. Wiedziałam, że mimo to, że urośnie na dużego psa, nikt go z domu nie wyrzuci. Dla Ojca było jasne, że zaakceptuje go od początku. I tak się stało. Szybko zaprzyjaźnili się, bawili, tarzali po podłodze i robili inne śmieszne akrobacje $(;)$ Pies szybko urósł i był naszym obronnym domownikiem. Nie zapomnę podróży wakacyjnej z Tatą i Mamą, i wspólnego pływania. Mimo że nie było potrzeby, Bruno bardzo chciał ratować Ojca w wodzie, jednoczésnie łapami drapiąc po ciele. To było urocze: jedno goniło, drugie uciekało (:). Tak jak i w przypadku Kubusia, Tata wyprowadzał Bruna zawsze rano i dawał mu chrupki i coś ekstra, tzn. bułeczkę z masłem, którą uwielbiał i bez której nie kończył śniadania. Brak bułki oznaczał skarge do Mamy (-). Takie to było psisko... (;). Ten nasz przyjaciel też niestety już odszedł, żył podobnie jak poprzednik 10 lat, ale wspomnienia zostały.

Przyszedł czas na kolejnego psa. Pod kryptonimem „zabieg chirurgiczny ręki” w Poznaniu, Tata przywiózł nowy egzemplarz. Tym razem był to pies rasy eurazjer; śmieszna, pluszowa rasa, połączenie chow-chow i samojeda. Tata wyszedł z pociągu z ręką na temblaku, a na nim siedział piesek. To się brat zdziwił, odbierając Ojca z dworca... (:) Zabieg też się odbył, wszystko się udało, ale nie był to jedyny powód tej wycieczki.

Ten pies nazywał się Moran. Imię nie byle jakie, bo należało do masajskiego bojownika i Tata uznał, że idealnie nadaje się na naszego nowego domownika. Los chciał jednak, że akurat ten egzemplarz był dość płochliwy, nie lubił, jak ktoś zwracał na niego uwagę i w ogóle na niego patrzył. Wszelkie próby zmiany jego nastawienia kończyły się ucieczką psa. Szczekać też nie za bardzo lubił, ale potrafił z zaskoczenia ugryźć tego, kto mu się naprzykrzał. Tata, podobnie jak Mama, był bardzo z nim związany. Jak zwykle zawsze rano wychodzili na spacerek, zawsze pies towarzyszył rodzicom na wakacjach. W zasadzie Moran nigdy nie był sam. Na tego przyjaciela niestety też przyszedł czas i zmarł w zeszłym roku. Rodzice długo dochodzili do siebie, bo był z nimi 
13 lat. To był ewidentnie pies rodziców, my z bratem mieszkaliśmy już na swoim i nie byliśmy z Moranem aż tak bardzo związani, ale bardzo cieszyliśmy się na jego widok i on na nasz.

Ale mamy ciąg dalszy psiej historii w życiu Taty... Nastał nowy czas i wiedzieliśmy z bratem, że jest to tylko kwestia tygodni, jak kolejny pies pojawi się w domu rodzinnym. Minęło kilka miesięcy i pojawił się nasz aktualny towarzysz, tym razem Szon, pies rasy iście królewskiej, a mianowicie Corgi Welsh Cardigan. Tak, to jest ta sama rasa, co ulubiona przez brytyjskie salony królewskie, zatem imię też nie mogło być nieadekwatne. Szon jest niewysoki, ma biało-czarne umaszczenie, krótkie łapki i duże uszy. Jest niesamowicie przyjacielski, wesoły, kochający zabawę, nie usiedzi w miejscu, wynosi wszystkie buty, klapki i inne niespodzianki z domowych szuflad. Jest bardzo zaradny, sam sobie otwiera szafy, niektóre drzwiczki, niestety śmieci też chętnie wyniesie (:). Historia jego zakupu była równie ciekawa jak poprzednika, ale tym razem zadanie odbioru Szona z Łodzi dostał brat, bo Tata z Mamą wracali z wakacji znad morza i zdaje się, ze Tata niekoniecznie chciał konfrontacji z Mamą na temat psa. Tak czy inaczej: pamiętamy datę; był to 15 lipca zeszłego roku, jak dołączył do nas piąty już pies. Czas pokaże, jakie przygody czekają jeszcze Tatę w relacji z Szonem, ale zapowiada się bardzo ciekawie... (;)

\section{Oczami Syna}

Dóżnica wieku między mną a siostrą to tylko dwa lata. Oczywiście - teraz te dwa lata nie znaczą zupełnie nic, ale kiedy byliśmy dziećmi to była przepaść. Siostra zawsze była tą młodszą. Dorastaliśmy w czasach PRL, w zasadzie w jego schyłku, ale pamiętamy kolejki, kartki, stan wojenny itd. Różnice w kolorach miast na tzw. zachodzie Europy w porównaniu z naszą szarością blokowisk. 
Nie było źle. Było inaczej. Zawsze będę miło wspominał ten okres, szczególnie czasy dojrzewania.

Tata. Jak w większości domów był głową rodziny. To on zarabiał pieniądze i nas utrzymywał. Był trochę oderwany od rodzinnej rzeczywistości, ale dlatego, że był absolutnie pochłonięty zdobywaniem wiedzy. Nie było go często, pamiętam liczne jego wyjazdy. Bardzo często go nie było. Na początku były to „demoludy”, niech starsi wyjaśnią młodszym, potem „zgniły” Zachód - głównie RFN.

Pamiętam, jak Tata uczył się niemieckiego. W szufladzie jego biurka wszędzie przewalały się karteczki z odręcznie napisanymi po niemiecku słowami, a na rewersie ich tlumaczenie na polski.

Dla nas bardzo dużym wydarzeniem były imprezy w domu. To było coś wspaniałego. Mama często robiła pizzę, taką trochę inną niż te, co znamy obecnie, ale przepyszną. Imprezy były do świtu, zawsze to były takie domowe „posiadówy”... Ale te dyskusje... i my z siostrą zasypiający pod stołem. Coś pięknego.

Pamiętam, jak pewien profesor z Niemiec, podczas jednej z domowych kolacji, na pytanie, czy był wcześniej w Polsce, może mało dyplomatycznie, ale zabawnie odpowiedział, że tak, ale razem z niemiecką artylerią w 1939 roku - dość osobliwy żart :)

Samochody. Pierwszy samochód. Maluch. Piękny, nowy. Prędkość maksymalna $105 \mathrm{~km}$. Czteroosobowy bolid, którym z zawrotną prędkością $90 \mathrm{~km} / \mathrm{h}$ mknęliśmy całą rodziną $2+2$ na wakacje do Ustki. Wszyscy się zmieśsiliśmy. Nawet spaliśmy z siostrą w podróży. Ale drogi były piękne. Podejrzewam, że i tak jechało się szybciej niż teraz. W ogóle nie było ruchu.

Potem. Duży Fiat. Zakup tego Fiata to było wydarzenie, którego nie zapomnę do końca życia. Kolor orzech, wersja za walutę z oponami uwaga - Good Year. Kolor - jaki byl, czyli nam się trafił jasny orzech. W zasadzie był to kolor nieokreślony. Ale i tak to był samochód, który potrafił być prawie tak szybki jak statek Enterprise ze StarTrek. Tak go wtedy postrzegałem. 
To dwa najważniejsze auta mojego dzieciństwa. To Tata je miał. Dla mnie, chłopaka interesującego się samochodami, Tata - ich właściciel, dobry kierowca, na pewno wzmacniał swój autorytet. Nie widziałem i nie dostrzegałem jego zawodowych osiągnięćc. To mnie w ogóle wtedy nie interesowało.

W czym mój Tata jest dla mnie i dla siostry taki wyjątkowy? Jest oczytany, zna historię i mnóstwo różnych opowieści. Dla mnie, teraz 46-letniego faceta, jest ważne to, że te historie zawsze były obiektywne. Nigdy od Ojca nie słyszałem słów potępiających jakiś obcy naród, gloryfikujących nasz kraj jako ten jedyny wybrany. To od mojego Taty dowiedziałem się, że każda historia ma gdzieś swoją przyczynę, a nienawišć do inności wynika ze słabości.

Jestem częścią świata innego niz świat mojego Taty. Ale to jego postawa i nauki z opowiadanych przez niego historii kształtują moje postępowanie. Jemu zawdzięczam to, ze jestem osobą otwartą, ze łatwo nawiązuję kontakty, i zanim coś będę ocenial, wcześniej będę chciał to poznać.

Pamiętamy wspólne z Tatą i Mamą wakacje. Były to czasy komuny, zatem kierunek ograniczał się do krajów należących do poprzedniego ustroju. Nasza pierwsza zagraniczna podróż była do Bułgarii, kraju bardzo innego w naszych oczach, bardziej egzotycznego, chociażby z uwagi na klimat. Pamiętamy: było bardzo ciepło, pogoda piękna, słoneczna, ciepłe morze, dobre owoce i nasi Rodzice, bawiący się na parkiecie. I tu, uwaga, w pamięci utknęły nam sandały Taty. Już wtedy nie mogliśmy zrozumieć, jak takie obuwie można nosić, mało tego: nawet w nim tańczyć $(-)$. Jak się okazało, można: zarówno jedno, jak i drugie. Dla dorastającego chłopca, który już orientował się, co jest modne, a co démodé, ten but był porażką. Sandał teraz, a sandał za komuny to jak porównanie walonek do australijskich butów firmy Emu. Problem w tym, że dla pokolenia naszych rodziców, którzy jako dzieci latali boso, nienawiść do sandała była niezrozumiała. Dla mnie wtedy sandał 
odbierał dumę, urodę i pewność siebie. Był brzydki i aseksualny. Tak brzydki, że nawet w Bułgarii na wakacjach nikt nie ukradł pary, na którą zostałem skazany przez Tatę i Mamę. A tam, na tych wczasach była też taka piękna córka ambasadora PRL we Francji. Ale niestety sandał zniweczył moje zauroczenie.

Takie były czasy i taki asortyment w sklepach. Trudno się dziwić rodzicom, kupowali, co było dostępne. Dziś jednak pozostają miłe wspomnienia, mimo że wówczas to była katorga.

7 okazji Twoich 70. urodzin życzymy Ci Tato przede wszystkim dużo zdrowia i radości w życiu, aby kolejne lata przyniosły $\mathrm{Ci}$ tak samo dużo satysfakcji, jak we wszystkich poprzednich latach.

Ponad wszystko życzymy dużo spokoju w gronie otaczającej Ciebie rodziny i najblizszzych, i przyjaciół, i pociechy z kolejnego psiaka!

\author{
córka Anna \\ syn Barttomiej
}

Warszawa, 17 lipca 2018 


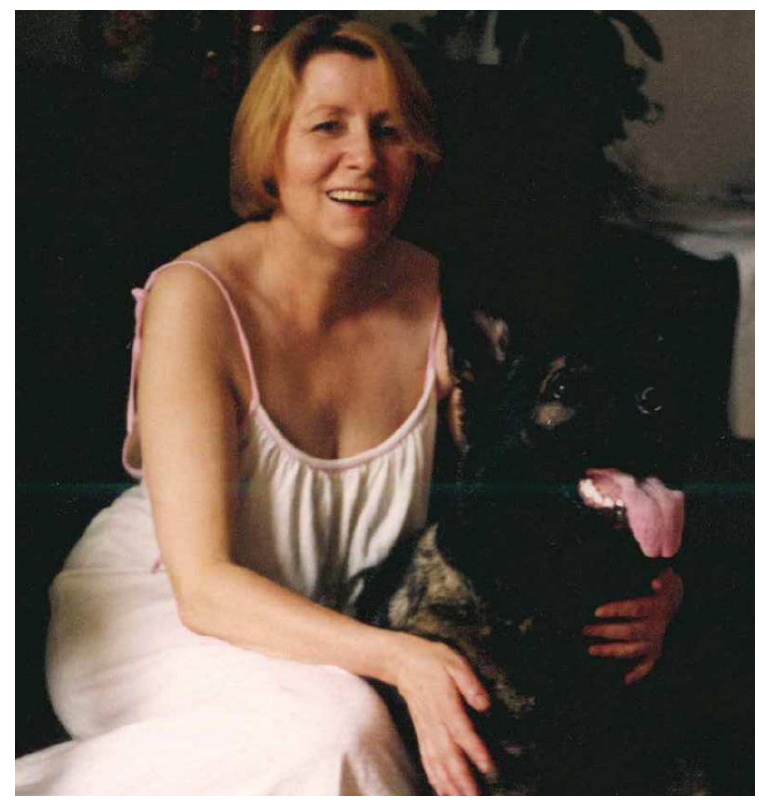

Żona Elżbieta z psem Bruno, mieszkanie na Służewcu, 1998 rok Fot. $z$ domowego archiwum A. Sopoćko.

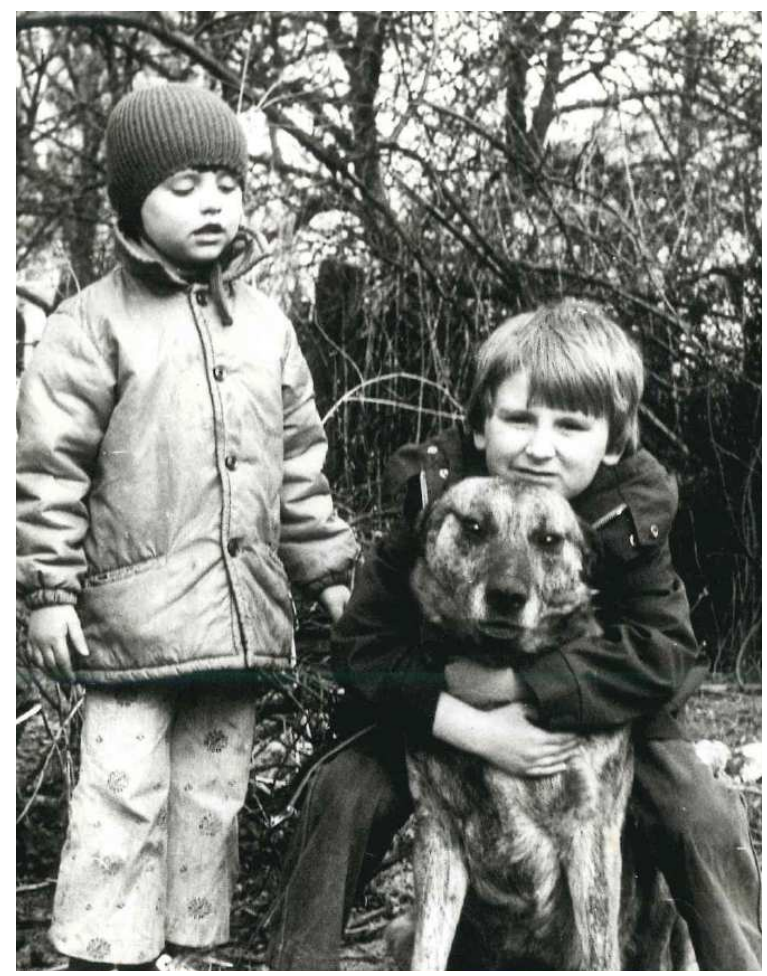

Córka Ania i syn Bartek z psem Babci Reksem, Sobolew, rok 1982 Fot. $z$ domowego archiwum A. Sopocko. 


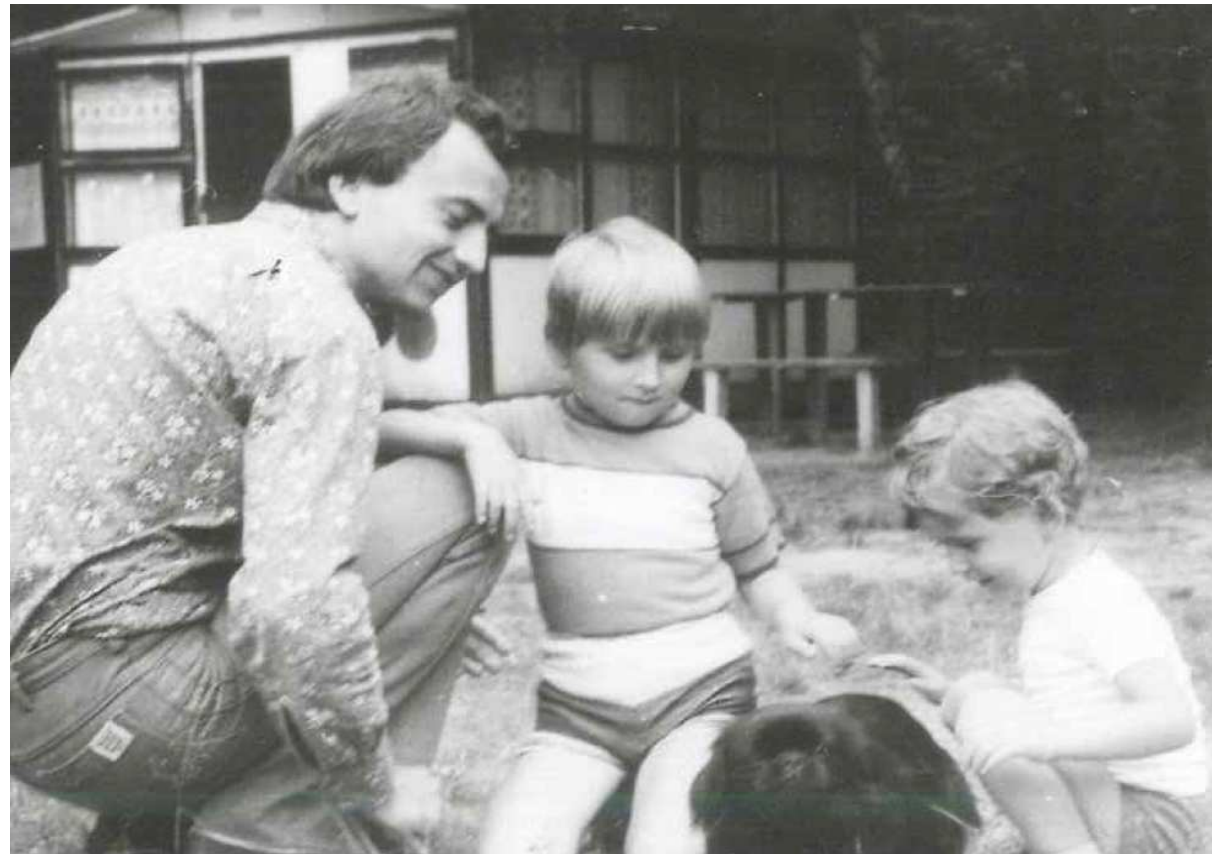

Ojciec klęczy z dziećmi (Ania i Bartek), wakacje nad morzem ok. 1978-1979 Fot. $z$ domowego archiwum A. Sopoćko.

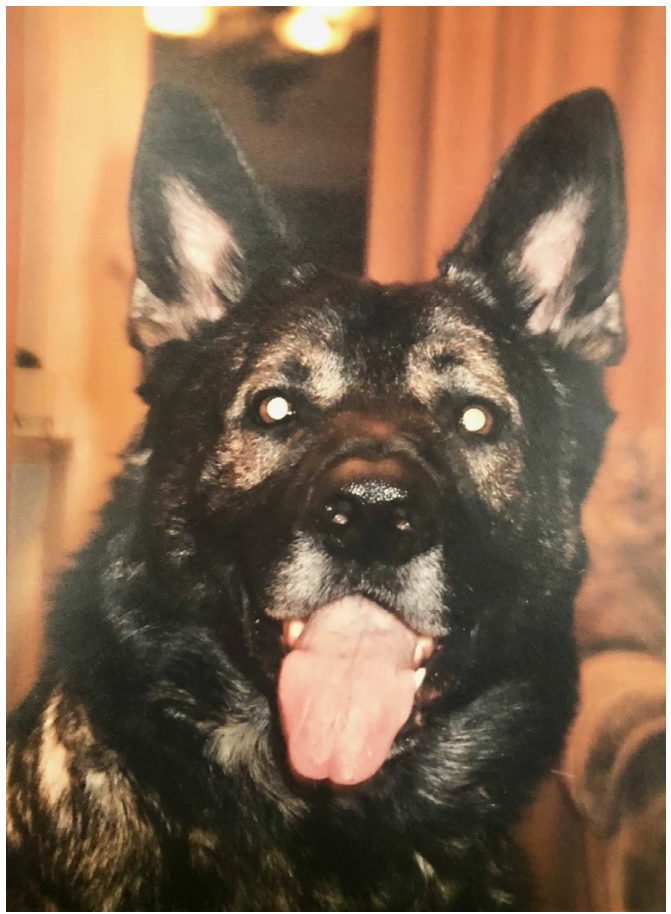

Ulubieniec Rodziny - pies Bruno

Fot. $z$ domowego archiwum A. Sopoćko. 


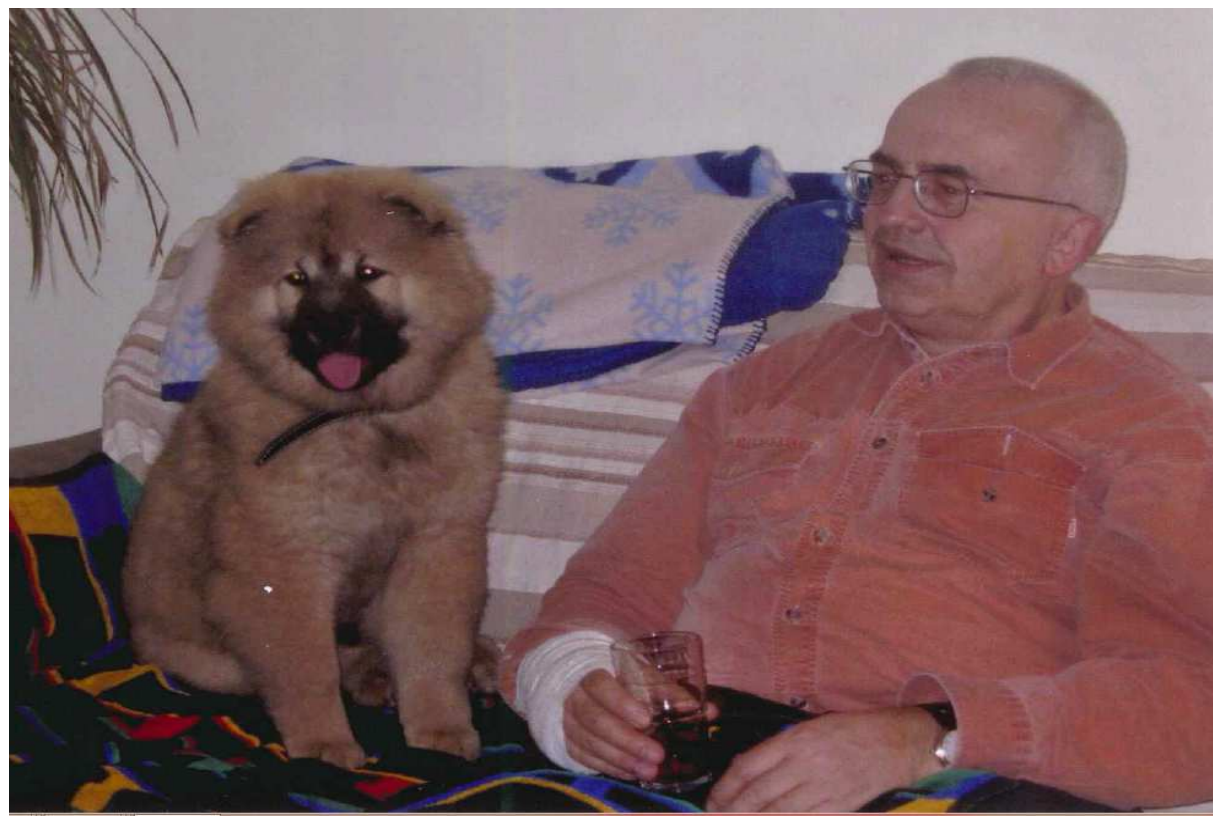

Życie ma swoje uroki, szczególnie z takim towarzyszem

(Andrzej z psem Moranem)

Fot. $z$ domowego archiwum A. Sopoćko.

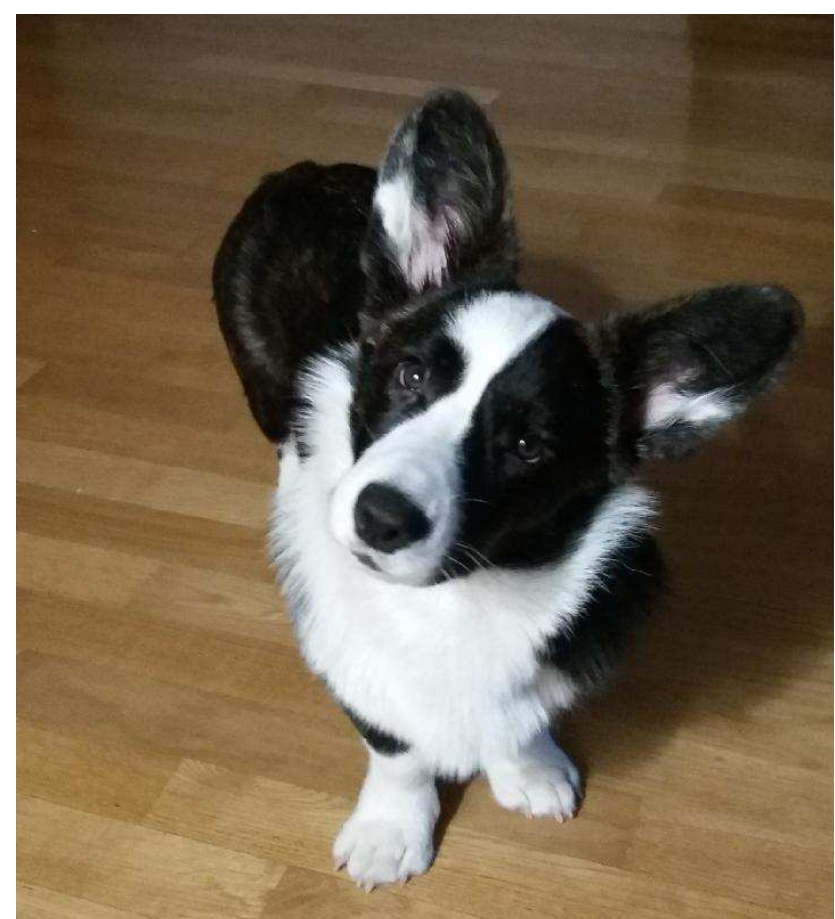

Szon - pies rasy królewskiej Corgi Welsh Cardigan

Fot. $z$ domowego archiwum A. Sopoćko. 


\section{Nauka i środowisko akademickie}





\section{Alojzy Z. Nowak}

\section{Dziekan o Jubilacie}

W

zdecydowanej większości przypadków, kiedy Profesor obchodzi swój okrągły Jubileusz, Jego koledzy, współpracownicy i przyjaciele przygotowują Mu dzieło, składające się ze specjalnie przygotowanych tekstów naukowych, będących rozwiązaniem jakiegoś problemu badawczego bądź przeglądu literatury. Czasami Jubilat wie o przygotowywanym dziele, a czasami nie. Najczęściej redaktorem takiego opracowania jest jeden z uczniów Profesora-Jubilata.

W przypadku Profesora Andrzeja Sopoćko jest inaczej. Andrzej przy aprobacie swoich uczniów, kolegów i przyjaciół zrezygnował z dzieła naukowego „na swoją cześć”, a poprosił o przygotowanie prezentacji Jego sylwetki widzianej oczami swoich kolegów, koleżanek i przyjaciól. Sam ten fakt świadczy zatem o pewnej „inności” Andrzeja.

Jest Profesor Andrzej Sopoćko osobą nietuzinkową. Postacią o renesansowym umyśle i bardzo szerokich zainteresowaniach. Poza ekonomią i finansami interesuje się historią, filozofią, sztuką i matematyką. Jego zainteresowania i wiedza w tym zakresie są głębokie i wzbudzają szacunek nie tylko dyskutantów amatorów, lecz także specjalistów z tego 
zakresu. Głęboka wiedza Andrzeja i otwartość na inne poglądy pokazują także Jego mądrość. Wynika z niej otwartość na poglądy innych i dążenie do poszukiwań prawdy. Jest przy tym Andrzej człowiekiem ciepłym, akceptującym i wspomagającym innych, zarówno tych, dla których jest Mistrzem, jak i tych, którzy są dla niego alukatorami.

Profesor Andrzej Sopoćko pełnił wiele funkcji państwowych i zarządczych. Zawsze jednak pamiętał o tym, że szacunek i mądrość nie są pochodną ani nominacji, ani pełnionych funkcji. To pomagało mu we wspomaganiu rozwoju swoich współpracowników zarówno tych zdobywających szlify naukowe, jak i tych, którzy te szlify już posiadali, a byli na drodze do awansu. Dyskusje naukowe prowadzone z Andrzejem są wielką przyjemnością. Jest to z jednej strony rezultat Jego postawy życiowej, polegającej na akceptacji inności i odmienności poglądów, z drugiej zaś wynik przyjęcia i akceptacji prymatu wiedzy i argumentacji merytorycznej nad argumentacją polityczną i ideologią.

Jest Profesor Andrzej Sopoćko dobrym kolegą i przyjacielem. Osobą przy tym skromną i niewywyższającą się. Jest odważny i wyraziście prezentuje swoje poglądy, często różniące się od poglądów innych. $\mathrm{Na}$ Radach Wydziału jest filarem dyskusji merytorycznych dotyczących zarówno strategii rozwoju wydziału, jak i programów studiów i prowadzonych badań.

Andrzej lubi ludzi, a ludzie lubią Jego. Ma wielu kolegów i koleżanek, zarówno w kraju, jak i za granicą. Jest zapraszany na liczne konferencje, seminaria i sympozja. Świadczy to wszystko o wysokim uznaniu w środowisku naukowym, gospodarczym i społeczno-politycznym. Gdziekolwiek Andrzej się znajduje, pozostawia ślad, którym podążają inni. To z kolei świadczy o jego oryginalności.

Andrzej jest dobrym ojcem, dziadkiem i mężem. Rodzina zawsze odgrywa w Jego życiu ważną rolę. Widać to zarówno w relacjach Jego z bliskimi, jak i w odniesieniu Jego Bliskich do niego.

Profesor Sopoćko kocha zwierzęta i, prawdę mówiąc, Jego oczkiem w głowie są poza bliskimi psy, których miał w swoim życiu kilka i które 
zawsze traktowane były przez Andrzeja jak bliscy członkowie rodziny i społeczności akademickiej.

Andrzeju - z okazji Twojego pięknego Jubileuszu życzę $\mathrm{C}_{\mathrm{i}}$ wszystkiego, co najpiękniejsze, zdrowia, szczęścia i dalszych oryginalnych koncepcji rozwoju społeczeństwa i ekonomii.

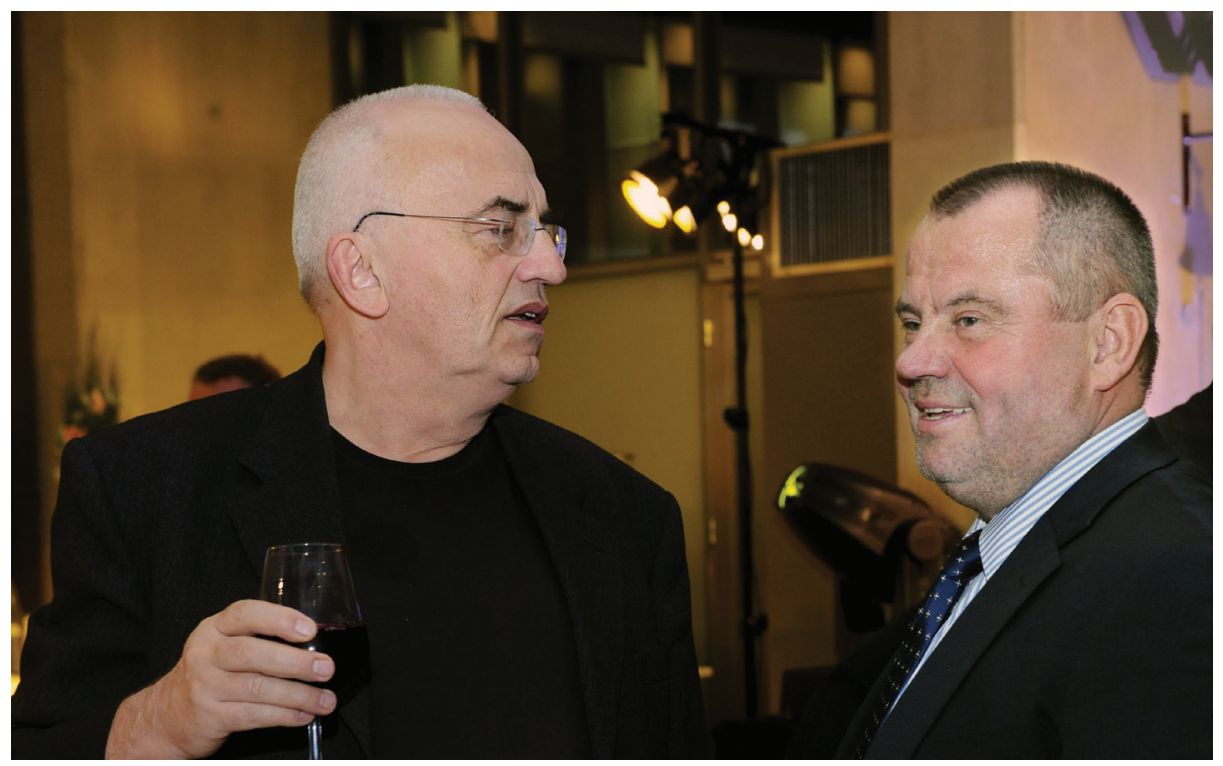

Uroczysta kolacja podczas Kongresu Rynku Kapitałowego. Profesor A. Sopoćko z Dziekanem Alojzym Z. Nowakiem Fot. Jerzy Krupowies. 


\section{Barbara Czarniawska}

\section{Wspomnienia ze Szwecji...}

Tytuł doktora nauk ekonomicznych Andrzej otrzymał 24 marca 11977 roku w Szkole Głównej Planowania i Statystyki. Same obrony odbyły wcześniej, Andrzeja w maju, moja w lipcu 1976 roku. Naszym promotorem był profesor Janusz Beksiak, dzięki któremu napisaliśmy nasze prace - moim zdaniem - wyjątkowo szybko. Trzeba pamiętać, że w tamtych czasach nie było studiów doktoranckich (choć za chwilę miały się zacząć). Praca Andrzeja analizowała regulatory rynku artykułów konsumpcyjnych, ponieważ jest on prawdziwym ekonomistą, moja natomiast lączyła psychologię z ekonomią - wtedy bowiem nie można było mieć doktoratu z zarządzania (co również się szybko zmieniło).

Obydwoje byliśmy zaangażowani w problem węzłowy Funkcjonowanie, organizacja $i$ kierunki rozwoju handlu wewnętrznego $w$ Polsce na IHWiU w latach 1972-1975, ale Andrzej nie był włączony w badania terenowe, które prowadziliśmy. Ja pełniłam funkcję doradcy metodologicznego, a Andrzej krytykował i doradzał nam, kiedy pisaliśmy sprawozdania z badań (w każdym tomie zamieszczone są dla niego podziękowania). W 1978 roku Andrzej rozpoczął pracę na Wydziale 

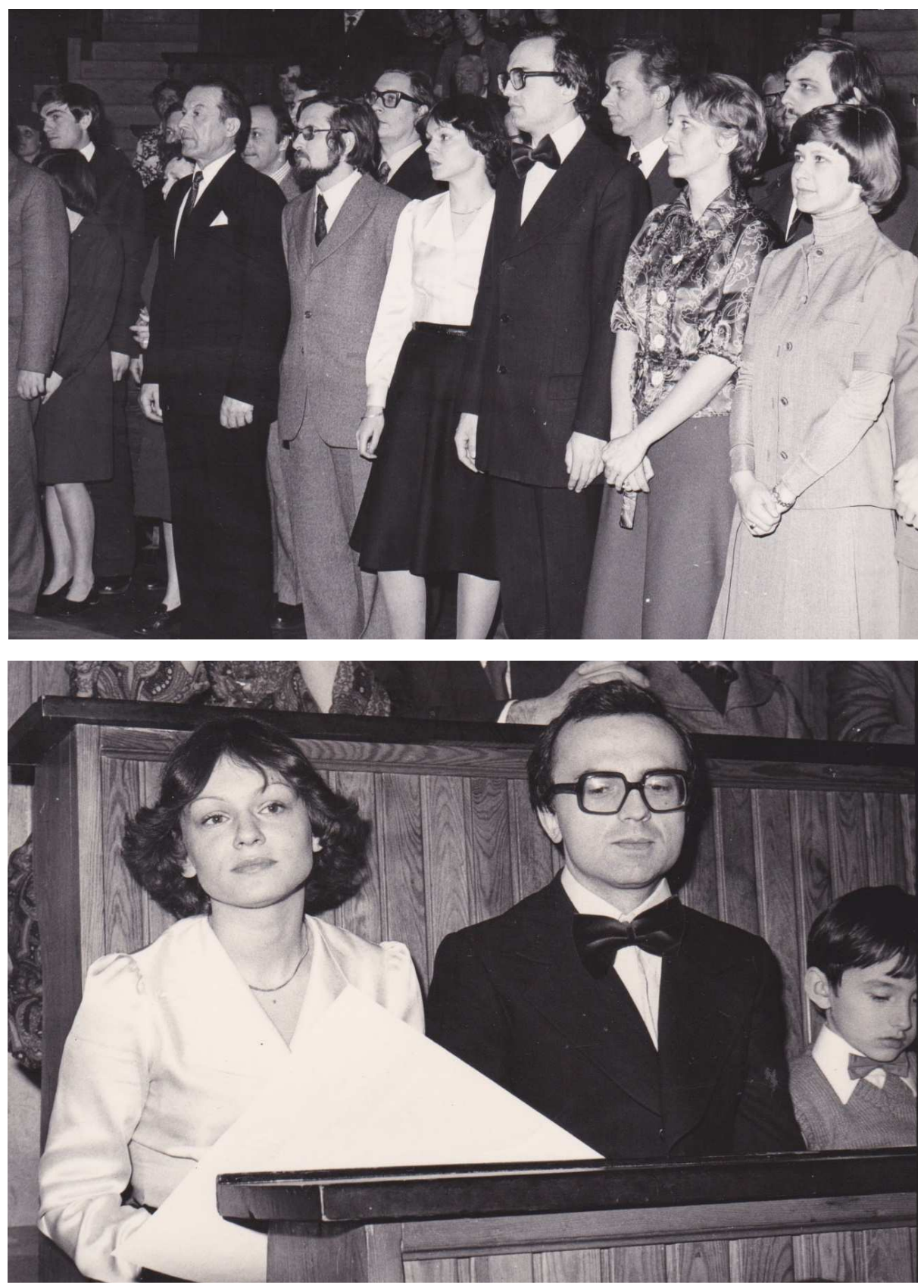

Zdjęcia z uroczystości na SGPiS-ie 24 marca 1977 r., kiedy to Andrzej i ja otrzymaliśmy nasze tytuły doktora nauk ekonomicznych Fot. Michat Dąskki. 
Zarządzania Uniwersytetu Warszawskiego, skąd ja już w roku 1979 powróciłam na psychologię. Nasz były promotor informował nas jednak o postępach (i przeszkodach) w naszych karierach. Dowiedziałam się od niego, że Centralna Komisja Kwalifikacyjna uważała, że Andrzej był za młody, aby zostać docentem, choć habilitował się już w 1979 roku. Ponieważ jesteśmy z tego samego rocznika, Beksiak poradził mi, żebym trochę zaczekała. Jednak w 1981 roku wyjechałam z Polski, i nie byłam już świadkiem dalszej fantastycznej kariery Andrzeja...

Jedno, czego żeśmy się nie spodziewali, to tego, że przyjdzie nam skończyć 70 lat... Wszystkiego najlepszego, Andrzeju, i oby tak dalej!

Barbara Czarniawska Senior Profesor organizacji i zarządzania Uniwersytet $w$ Góteborgu 


\section{Jan Czekaj \\ Stanisław Owsiak}

\section{Andrzej Sopoćko: \\ przyjaciel, uczony, działacz państwowy}

\section{Przyjaciel}

Doczytujemy sobie za zaszczyt możliwość napisania okolicznościowego
tekstu z okazji 70. urodzin prof. zw. dr. hab. Andrzeja Sopoćko. Przez prawie 30 lat naszej znajomości z Andrzejem mieliśmy możliwość wejść do grona Jego przyjaciół, czerpaliśmy z jego dorobku naukowego - czy to czytając Jego publikacje, czy też odbywając bezpośrednie dyskusje na temat ważnych problemów naukowych. Wreszcie - mieliśmy także okazję spotykać się, pracując wspólnie na rzecz różnych instytucji publicznych. Nie ulega dla nas wątpliwości, że nasze życie towarzyskie, osiągnięcia naukowe oraz działalność publiczna były i są bogatsze dzięki temu, że na naszej życiowej drodze mieliśmy okazję spotkać Profesora Andrzeja Sopoćko. 
Jeden z nas (Jan Czekaj) poznał Profesora w trakcie Capital Market Workshop, wspólnego przedsięwzięcia Georgetown University oraz Instytutu Finansów, zorganizowanego w roku 1989 w Waszyngtonie. Wspomnienie o tym seminarium jest o tyle istotne, że można je uznać za początek prac nad przebudową systemu finansowego polskiej gospodarki, w tym zwłaszcza budową rynku kapitałowego. W seminarium tym uczestniczyło wiele osób, które w następnych latach odegrały czołową rolę w budowie instytucji rynku kapitałowego w Polsce, czy też szerzej - w procesie transformacji gospodarki planowanej centralnie w gospodarkę rynkową. Do uczestników seminarium należeli m.in.: Lesław Paga, współtwórca i pierwszy przewodniczący Komisji Papierów Wartościowych i Giełd, Krzysztof Lis - pełnomocnik rządu ds. prywatyzacji, Grzegorz Jędrzejczak - późniejszy wiceminister Przekształceń Własnościowych, prof. Andrzej K. Koźmiński oraz wiele innych osób, które pełniły różne funkcje publiczne w pierwszym okresie transformacji polskiej gospodarki, przyczyniając się do stworzenia infrastruktury rynków finansowych, bądź to bezpośrednio uczestnicząc w ich tworzeniu, bądź też poprzez działalność naukową i publicystyczną. Dla nas obu udział w tym seminarium był o tyle ważny, że wpłynął na naszą późniejszą działalność naukową oraz publiczną, które, generalnie rzecz biorąc, koncentrowały się na problematyce transformacji gospodarczej, ze szczególnym uwzględnieniem budowy podstaw rynków finansowych.

Drugi z nas (Stanisław Owsiak) miał przyjemność spotykania Profesora Andrzeja Sopoćko również na początku lat 90. w związku z wspólną działalnością w Radzie Strategii Społeczno-Gospodarczej (RSSG). Profesor był częstym uczestnikiem sesji RSSG, a Jego wiedza teoretyczna z ekonomii, finansów, bankowości, znajomość mechanizmu funkcjonowania gospodarki rynkowej, pełnione wysokie funkcje w administracji rządowej, wzbogacały debaty na tym unikalnym forum teoretyków i praktyków, nadając im użyteczny wymiar. Profesor Andrzej Sopoćko, z racji pełnionej funkcji wiceministra finansów nadzorującego 
sektor bankowy, desygnował prof. Stanisława Owsiaka do Rady Bankowego Funduszu Gwarancyjnego w trudnym okresie działalności BFG, kiedy następowały radykalne zmiany w sektorze banków spółdzielczych $\mathrm{w}$ Polsce, co implikowało zaangażowanie się BFG w procesy sanowania banków spółdzielczych oraz ich restrukturyzację. Można wyrazić nadzieję, że zaufanie, którym Profesor obdarzył współautora tego tekstu nie zostało zawiedzione, gdyż powierzoną funkcję w BFG S. Owsiak pełnił do czasu powołania do Rady Polityki Pieniężnej (2004). Zaangażowanie Profesora Andrzeja Sopoćko w sprawy funkcjonowania sektora finansowego w Polsce było i jest nadal widoczne. Ostatnim tego wyrazem jest członkostwo i aktywne uczestnictwo w pracach Doradczego Komitetu Naukowego przy Rzeczniku Finansowym, którego członkami są również autorzy niniejszego tekstu.

Ta część naszego tekstu jest dla nas o tyle ważna, że o ile niezwykle wysoko cenimy wkład Profesora w rozwój nauki, w reformę systemu gospodarczego Polski, o tyle dla nas najważniejsze jest to, że możemy się zaliczać do Jego przyjaciół.

\section{Uczony i krzewiciel wiedzy o gospodarce $i$ rynkach finansowych}

Jie sposób w tekście o stosunkowo niewielkiej objętości scharakteryAndrzeja Sopoćko. Podstawą Jego późniejszej aktywności naukowej i zawodowej było solidne wykształcenie ekonomiczne w renomowanej w Polsce uczelni - obecnie Szkole Głównej Handlowej. Wyniki osiągnięte podczas studiów zostały potwierdzone stosunkowo szybkim uzyskaniem stopnia naukowego doktora (1976) i jeszcze szybszym uzyskaniem stopnia naukowego doktora habilitowanego (1979) na tejże 
uczelni. Osiągnięcia naukowe, publikacyjne i inne rodzaje aktywności zawodowej Profesora Andrzeja Sopoćko znalazły uznanie środowiska i zostały potwierdzone nadaniem $\mathrm{Mu}$ tytułu naukowego profesora (1994). Zaproponowanie Profesorowi pracy naukowej w Uniwersytecie Warszawskim (1978) było więc wyrazem uznania i docenieniem Jego potencjału intelektualnego. Profesor Andrzej Sopoćko na uczelni tej pracuje do dzisiaj, gdzie kieruje Zakładem Ubezpieczeń i Rynków Kapitałowych. Ponadto, od 2007 roku, pracuje także na stanowisku profesora zwyczajnego w Instytucie Nauk Ekonomicznych Polskiej Akademï Nauk.

Dorobek publikacyjny Profesora obejmuje ponad dziewięćdziesiąt pozycji książkowych i artykułowych opublikowanych w renomowanych czasopismach krajowych, takich jak np. „Ekonomista”, „Studia Ekonomiczne" i w innych wydawnictwach w języku polskim, angielskim i niemieckim. Z pierwszych prac zwartych na szczególne wyróżnienie zasługuje książka pt. Giełda papierów wartościowych (PWE, Warszawa 1991). Praca ta świadczy o zainteresowaniu Profesora gospodarką kapitalistyczną i jej funkcjonowaniem znacznie wcześniej, niż rozpoczęła się transformacja ustrojowa w naszym kraju. Wiedza ta pozwoliła na rychłe opublikowanie tej niezwykle potrzebnej w polskiej literaturze pozycji u progu wielkich przemian w ustroju gospodarczym. Praca ta, napisana nad wyraz przystępnie, stanowiła cenną pozycję, z której korzystało wiele roczników studentów i młodych naukowców. $\mathrm{O}$ jej walorach merytorycznych świadczy fakt, że zaprezentowana tam wiedza stanowiła argument za powoływaniem Profesora na różne funkcje na Giełdzie Papierów Wartościowych w Warszawie w latach jej tworzenia i rozpoczynania działalności (1992-1994), a następnie w latach 2003-2005 powierzeniem Mu funkcji wiceprezesa Zarządu Giełdy Papierów Wartościowych. Wkład Profesora Andrzeja Sopoćko w krzewienie wiedzy o gospodarce rynkowej powiększył się wraz z kolejną pozycją książkową pt. Rynkowe instrumenty finansowe (WN PWN, Warszawa 2010). Książka ta, ze względu na przystępność zawartych w niej, skądinąd trudnych i skom- 
plikowanych zagadnień, cieszyła się wyjątkową popularnością wśród studentów i osób zainteresowanych rynkiem finansowym.

Ważną cechą aktywności naukowej Profesora Andrzeja Sopoćko jest umiejętność łączenia osiągnięć naukowych z ich praktycznym spożytkowaniem. W'śód wielu płaszczyzn działalności na szczególną uwagę zasługuje współautorstwo i redakcja naukowa publikowanych systematycznie przez Związek Banków Polskich Raportów na temat stanu sektora bankowego w Polsce. Prace te, świadczące o doskonałym warsztacie analitycznym autorów, stanowily, obok oficjalnych dokumentów publikowanych przez Komisję Nadzoru Bankowego, Narodowy Bank Polski, ważną pozycję studialną i analityczną w okresie intensywnych przemian własnościowych, konsolidacyjnych, restrukturyzacyjnych w sektorze bankowym. Jest więc wielką zasługą Profesora Andrzeja Sopoćko, że swoją wiedzą przyczynił się do rozwoju sektora bankowego i - szerzej - sektora finansowego w naszym kraju.

Dla zainteresowań naukowych Profesora Andrzeja Sopoćko charakterystyczna jest reakcja na aktualne ważne zagadnienia $\mathrm{w}$ gospodarce blizzzzej i dalszej. Wyrazem tego jest np. artykuł pt. Speculation - the scale of danger to global and domestic monetary equilibrium („Studia Ekonomiczne" 2006/3), w którym Autor dostrzega narastające niebezpieczeństwa związane ze spekulacją na rynkach finansowych, jednakże formułuje tezę, że im większa liczba aktywnych inwestorów, tym bliżej do idealnego rynku. Wyrazem zaangażowania Profesora Andrzeja Sopoćko w bieżącą debatę ekonomiczną jest Jego głos w sprawie terminu przystąpienia Polski do strefy euro. Ówczesne stanowisko w tej kwestii wyraził na łamach „Studiów Ekonomicznych” (2008/1-2) w publikacji pt. Im dlużej bez euro, tym więcej zmarnowanych szans rozwoju polskiej gospodarki.

Z twórczością naukową Profesora Andrzeja Sopoćko w ogóle jest pewien problem, gdyż Jego prace trudno jest zaszufladkować. Prawdopodobnie są one najbliższe ekonomii i finansom heterodoksyjnym. 
Opinia taka może być pewnym zaskoczeniem, gdyż Profesor docenia realia ekonomiczne, co nie zaskakuje, skoro pełnił ważne funkcje w administracji gospodarczej państwa, gdzie jednak dominuje ekonomia konwencjonalna. Tymczasem $\mathrm{w}$ wielu swoich pracach proponuje rozwiązania, które idą wbrew obowiązującym kanonom. Prace te można natomiast śmiało zakwalifikować jako wkład w poszukiwanie nowego paradygmatu ekonomii, co stało się szczególnie intensywne po kryzysie finansowym 2008 plus. Dowodem na to jest ostatnia Jego książka pt. Mit pieniądza. Świat realny wobec iluzji polityki pieniężnej (WN PWN, Warszawa 2015). Praca ta, tylko przez przeoczenie, została zgłoszona po terminie do Konkursu Polskiego Towarzystwa Ekonomicznego im. Edwarda Lipińskiego, stąd nie mogła być brana pod uwagę, tymczasem miałaby duże szanse na zwycięstwo.

Pracę tę można traktować jako swoisty manifest naukowy Profesora, dlatego zasługuje ona na szersze omówienie. Zanim jednak przejdziemy do bardziej dokładnego scharakteryzowania Jego poglądów, zawartych w tej pracy, trudno nie zauważyć, że jej idea dojrzewała przez wiele lat. Dowodem na to są wcześniejsze publikacje, takie jak artykuł pt. Gra finansowa - stagnacja czy wzrost bogatego świata („Ekonomista” 4/2012), w którym Autor trafnie wskazał na błędy polityki pieniężnej, ograniczone możliwości wzrostu konsumpcji prywatnej w kreowaniu popytu $\mathrm{w}$ gospodarce, niedocenianie roli konsumpcji publicznej, negatywne skutki wzrastających nierówności dochodowych dla zagregowanego popytu i szerszej wzrostu gospodarczego. Kontynuacją tych wywodów był następny artykuł Profesora pt. Pieniqdz niebankowy. $C z y$ istnieje możliwość powrotu („Studia Ekonomiczne” nr 4/2012), w którym Autor m.in. rozwija argumentację na rzecz niekonwencjonalnego finansowania konsumpcji publicznej.

Powracając do pracy Mit pieniadza. Świat realny wobec iluzji polityki pieniężnej, można wyraźnie stwierdzić, że Autor zdecydowanie opowiada się za zerwaniem z iluzjami polityki pieniężnej, której skutkiem jest ograniczenie dopływu pieniądza emisyjnego dla rządu, co stanowi jedną 
$\mathrm{z}$ ważnych przyczyn hamowania popytu w gospodarce. Innymi słowy: Autorowi chodzi o zerwanie z zasadą przyjętą w traktacie z Maastricht, a zakazującej finansowania bieżących potrzeb pożyczkowych rządu przez bank emisyjny. Profesor Sopoćko proponuje taką organizację systemu emisji pieniądza, w którym istniałyby dwa kanały. Pierwszy z nich polegałby na bezpośrednim zasilaniu budżetu państwa (rządu) przez bank centralny, drugi kanał natomiast zapewniałby dopływ pieniądza do sektora komercyjnego. U podstaw tych śmiałych, a tym samym kontrowersyjnych poglądów, legły wnikliwe obserwacje, potwierdzone wieloma danymi faktycznymi, nie tylko w okresie kryzysu finansowego, ale - co ważne - także we wcześniejszych okresach, w których gospodarka wielu krajów była ograniczona popytem, a ekonomia podaży i stosowane w jej ramach narzędzia polityki pieniężnej były nieskuteczne. Nie przesądzając kategorycznie tego, czy proponowane rozwiązanie jest możliwe do zastosowania w praktyce, nie można odmówić Autorowi trafnie postawionej diagnozy o słabościach polityki pieniężnej w przyjętym modelu niezależności banku centralnego. Poglądy Autora są nam o tyle bliskie, że zostały one wyrażone w naszej publikacji na ten sam temat (J. Czekaj, S. Owsiak, O potrzebie rewizji paradygmatu o autonomii polityki monetarnej i polityki fiskalnej, w: J. Nowakowski (red.), W kierunku nowego ładu świata finansów, Oficyna Wydawnicza Szkoły Głównej Handlowej, Warszawa, 2015, s. 123-154).

Oceniając osiągnięcia poznawcze Autora, przedstawione w tej pracy, warto zwrócić uwagę na jej elegancką formę. Praca ta urzeka przejrzystością wywodu, jest napisana żywym, barwnym językiem. Autor przytacza wiele przykładów zaczerpniętych z życia pieniądza, przenosząc czytelnika w sferę zjawisk codziennych, których tworzywem jest pieniądz. Używa wielu analogii do rozpatrywanych zjawisk ekonomicznych w różnych dziedzinach życia (rzeczywistości), wydarzeń historycznych. Wszystko to bardzo ułatwia zrozumienie istoty rozważanych zagadnień. Argumentacja sformułowanych przez Autora tez (hipotez) podpierana jest trafnie dobranymi danymi empirycznymi z gospodarki wybranych 
krajów (obszarów), takich jak: Stany Zjednoczone, Japonia, Europa (Unia Europejska), Chiny, czasami Polska, co wzmacnia i uatrakcyjnia rozważania.

Chcielibyśmy wyraźnie podkreślić, że praca ma charakter oryginalny, a nie odtwórczy. Zapowiedzią takiego charakteru pracy są już same tytuły poszczególnych rozdziałów, w których zawarta jest explicite lub implicite oryginalna teza (hipoteza). Mogłoby wydawać się, że na temat pieniądza napisano i powiedziano już wszystko. Autor obala takie mniemanie i stwierdza, że dzieje się wręcz przeciwnie, a funkcjonowanie współczesnego pieniądza ma $\mathrm{w}$ sobie nadal tajemnice. Wymowny jest tytuł pierwszego rozdziału Rodowód pieniądza. Dlaczego daje się dotknać, a nie zrozumieć? Autor w sposób barwny, ale też merytorycznie głęboki, wyjaśnia genezę dzisiejszego pieniądza, etapy jego ewolucji. Stara się przy tym wyjaśnić, dlaczego wokół pieniądza wciąż istnieje wiele nieporozumień i mitów właśnie. Jest to ważki wkład Autora w toczącą się debatę nad dzisiejszym pieniądzem „tworzonym z niczego". Krytyczne i trafne są opinie Autora na temat reminiscencji i nostalgii do systemu waluty złotej, które pojawiły się w okresie kryzysu finansowego. Krytycznej analizie i ocenie poddany został obecny system tworzenia pieniądza oparty na banku centralnym, szczególnej roli banków komercyjnych, przy jednoczesnej eliminacji rządu (fiskusa) z tego procesu. Doceniając oryginalność poglądów Autora, nie można nie zauważyć, że Jego eleganckie wywody i propozycje są niekiedy nazbyt eleganckie, aby nie powiedzieć nazbyt ogólnikowe. Poszukując odpowiedzi na pytanie o rozmiary emisji (kreacji) pieniądza, Autor stwierdza, że pieniądza należy tworzyć tyle, żeby dostosować go do potrzeb gospodarki. Pogląd taki jest prawdziwy na wysokim stopniu abstrakcji. Wprawdzie w dalszych rozważaniach pośrednio wskazuje na to, pisząc o popycie wewnętrznym, konsumpcji prywatnej, konsumpcji publicznej, inwestycjach, ale kwestia ta powinna być jaśniej, ostrzej postawiona i wyjaśniona. Okoliczność ta nie umniejsza wysokich walorów prowadzonych rozważań. 
W pracy został poddany krytyce współczesny system tworzenia pieniądza i podważany jest paradygmat monopolu banku centralnego oraz systemu bankowego w ogóle na tworzenie pieniądza. W tym kontekście Autor sporo miejsca poświęcił senioratowi - zarówno w ujęciu historycznym, jak i w rozważaniach hipotetycznych, odnośnie do sytuacji, w której seniorat przywrócony byłby obecnie. Ciekawe są tutaj poglądy Autora na istotę długu publicznego, zgodnie z którymi dług publiczny nie może być rozpatrywany wyłącznie jako zagrożenie dla gospodarki. Autor trafnie wyeksponował błąd popełniany nagminnie w życiu codziennym, a także często $w$ literaturze naukowej, polegający na identycznym podejściu do długu publicznego tak jak do długu prywatnego (przedsiębiorcy, gospodarstwa domowego). Wielce odpowiada nam przedstawione przez Autora wyjaśnienie sensu długu publicznego w kontekście analizy przyczyn zaciągania długu, źródeł jego finansowania, skutków dla społeczeństwa. $Z$ analizy tej wynika, że opisywany często w literaturze, ale też $\mathrm{w}$ rozumieniu potocznym, mechanizm międzygeneracyjnego przesuwania ciężaru długu publicznego jest co najmniej dyskusyjny, jeśli nie błędny. Autor zwraca uwagę, że przy obecnym modelu tworzenia pieniądza w gospodarce rząd staje wobec dylematu: podnosić podatki czy zwiększać dług publiczny. Zgadzamy się z poglądem Autora, że $\mathrm{w}$ istocie rzeczy zjawisko długu publicznego nie jest groźne, gdyż to społeczeństwo samo sobie pożycza, a władze $\mathrm{w}$ ten sposób unikają, z powodów politycznych i ekonomicznych, konfliktu ze społeczeństwem, co groziłoby w przypadku podnoszenia obciązeń fiskalnych. Tak jest jednak przy zaciąganiu długu (finansowaniu) u podmiotów krajowych, czyli długu wewnętrznego. Nieco słabszą stroną tych rozważań jest łagodne przejście nad sytuacją, gdy dług publiczny jest zaciągany za granicą. Sprawę tę należałoby rozwinąć, gdyż mamy tutaj inną perspektywę. Japonia przy wysokim długu publicznym (około 240\% PKB) nie może być tutaj dobrym przykładem w rozważanym kontekście, gdyż kraj ten prowadzi autonomiczną politykę pieniężna, a dług jest niemal wylącznie finansowany walutą krajową. 
Główna teza Autora sprowadza się do tego, że polityka pieniężna i jej instrumenty przestały być skuteczne w dostarczaniu gospodarce pieniądza, a zwłaszcza pobudzania popytu. Zwraca uwagą dojrzałość tych rozważań w tym znaczeniu, że Autor analizuje te zagadnienia w związku ze zmianami w wydajności pracy, której tempo przewyższa wzrost konsumpcji (popytu). Zjawisko ograniczeń popytowych w gospodarce jest silnie wzmacniane przez nieustannie rosnące nierówności dochodowe, a to skutkuje tym, że zamożniejsze warstwy społeczeństwa istotną część dochodów lokują na rachunkach bankowych, w aktywach (złoto, dzieła sztuki), a nie na rynku, kreując popyt na dobra powszechne. W konstatacji Autor stwierdza pesymistycznie, że słabe są nadzieje na to, iż poprzez system podatkowy (progresywny) uda się zatrzymać ten groźny dla rozwoju gospodarki światowej trend. W tej sytuacji realistycznym wyjściem byłoby istotne uzupełnienie popytu zagregowanego wydatkami publicznymi i konsumpcją publiczną. Autor podkreśla, że o ile po stronie konsumpcji prywatnej ograniczenia popytowe są trudne do usunięcia między innymi dlatego, że system dochodów z pracy jest kształtowany przez mechanizm rynkowy, a ich korekta (podatki) napotyka wspomniane trudności, o tyle uzupełnienie popytu powinno dokonywać się przez wzrost konsumpcji publicznej, która - zdaniem Autora - powinna być finansowana (oprócz podatków) pieniądzem banku centralnego kierowanego wyłącznie do sektora publicznego (rządowego). Zgłaszając taką propozycję, Autor w wielu miejscach pracy podkreśla, że jest to ogromne wyzwanie w sensie realizacyjnym. Wymagałoby ono odejścia od zaleceń głównego nurtu, przywrócenia dochodów z senioratu w czasach współczesnych. Także praktyczna realizacja napotka bariery o charakterze normatywnym w państwach Unii Europejskiej, w których status banku centralnego i monopol systemu bankowego na tworzenie pieniądza jest uregulowany traktatami i innymi aktami prawnymi. Zgadzając się z Autorem, że jest to jeden z możliwych kierunków (środków) pobudzania wzrostu gospodarczego, nie można nie zauważyć, że przy takim rozwiązaniu pojawia się pewne zagrożenie dla równowagi ogólnej, infla- 
cji. Hipotetycznie można wyodrębnić dwa kanały dopływu pieniądza do gospodarki z banku centralnego, czyli do sektora prywatnego i do sektora publicznego, ale przecież tych dwóch sektorów nie da się hermetycznie odizolować. Przeciwnie: pieniądz kierowany do sektora rządowego szybko przemieści się do sektora prywatnego, w tym do komercyjnych banków, co może zachęcać je albo do ekspansji kredytowej (manipulowania oprocentowaniem), albo działalności spekulacyjnej.

Rozważania dotyczące możliwości dwukanałowego dopływu pieniądza z banku centralnego, czyli do sektora prywatnego i sektora publicznego, są wielce wartościowe, wyznaczają kierunek myślenia, mają jednak charakter ogólny, czemu nie należy się specjalnie dziwić ze względu na duży ciężar gatunkowy. Można je traktować jako propozycję do dyskusji, jeżeli uda się przekonać świat akademicki oraz polityków, do akceptacji wskazanych przez Autora kierunków zmian we współczesnym systemie ekonomicznym i politycznym.

Autor trafnie wyeksponował rozbieżności między zaleceniami ekonomii głównego nurtu, potwierdzonymi m.in. tzw. Konsensusem Waszyngtońskim, a pragmatycznym podejściem rządów i międzynarodowych instytucji finansowych do opanowania katastrofy wywołanej kryzysem finansowym. Gdyby nie to pragmatyczne podejście do narzędzi fiskalnych (deficyt, dług publiczny) i odrzucenie zalecanego przez ekonomię głównego nurtu podejścia do gospodarki, trudno byłoby sobie wyobrazić obecny stan gospodarki i finansów świata, Unii Europejskiej czy poszczególnych krajów. Jakkolwiek dzisiaj nie podnosi się tej kwestii głośno, to złagodzenie niebezpieczeństwa rozpadu strefy dokonało się głównie przez złamanie obowiązujących rozwiązań prawnych konstytuujących tę strefę, zapisanych w traktacie z Maastricht, a opartych na ortodoksyjnej teorii ekonomicznej. Profesor Sopoćko jest od wielu lat krytykiem tej teorii, Jego prace wskazywały na możliwość wystąpienia kryzysu.

Determinacji w głoszeniu swoich poglądów towarzyszy równie silne przekonanie Profesora o barierach, których przełamanie może okazać się trudne. Autor nie podważa niezależności banku centralnego, ale inaczej 
widzi relacje między bankiem centralnym a rządem. Zdaniem Profesora Sopoćko polityka pieniężna musi być prowadzona w związku ze wzrostem gospodarczym, równowagą ogólną, zatrudnieniem, wydajnością pracy, poziomem i strukturą wydatków publicznych, długiem publicznym, zróżnicowaniem dochodowym społeczeństwa. Takie podejście sprawia, że łatwiej jest zrozumieć główną tezę pracy, kwestionującą wyłączenie rządu z procesu tworzenia pieniądza i oparcie części wydatków budżetowych na dochodach płynących $\mathrm{z}$ senioratu.

Praca ta stanowi, naszym zdaniem, ukoronowanie dorobku i myśli Profesora Andrzeja Sopoćko, obok którego nie można przejść obojętnie. Jest inspirująca, a w niektórych miejscach prowokująca do refleksji, do debaty, do weryfikacji uznanych i zdaje się nienaruszalnych kanonów, na podstawie których funkcjonuje system pieniężny, a w konsekwencji cała gospodarska. Autor proponuje, i do czego jest absolutnie przekonany, jako wnikliwy badacz rzeczywistych zjawisk we współczesnej gospodarce, przewartościowanie poglądów (paradygmatu) polityki pieniężnej i jej skutków dla gospodarki. Praca ta dobrze oddaje cechy osiągnięć i warsztatu całego dorobku naukowego Profesora Andrzeja Sopoćko.

Ta książka, a także wcześniejsze publikacje Profesora, lokują jego poglądy w ramach teorii ekonomii, a zwłaszcza teorii pieniądza, zaliczanych do nieortodoksyjnych. W Jego pracach można znaleźć inspiracje pracami takich autorów, jak: Georg Knapp, Mitchel Innes, Abba Lerner, Hyman Minsky czy Robert Skidelsky, który w kontekście ostatniego kryzysu proponuje powrót do oryginalnych koncepcji Keynesa. Ostatnia publikacja Profesora Sopoćko, nawiązująca do poglądów tych autorów, skłania ekonomistów do sięgnięcia do koncepcji, które były nieobecne w polskiej ekonomii, a które mogą stanowić inspirację do twórczego spojrzenia na niezwykle ważne kwestie z zakresu teorii pieniądza i polityki pieniężnej, rozwijane przez tych, dziś w dużej mierze zapomnianych, badaczy. 


\section{Dziatacz państwowy}

W $\begin{aligned} & \text { ażną sferą działalności Profesora Andrzeja Sopoćko jest działal- } \\ & \text { nośc publiczna. Profesor nie tylko włączył się w proces transfor- }\end{aligned}$ macji polskiej gospodarki jako uczony, formułując koncepcje zmian czy też recenzując propozycje formułowane przez innych, lecz także uczestniczył aktywnie w procesie tworzenia nowych instytucji i instrumentów koniecznych dla właściwego funkcjonowania gospodarki rynkowej. W tej sferze działalności Jubilata mieliśmy również okazję do współpracy, którą cenimy sobie równie wysoko jak współpracę w sferze naukowej.

Pracę w instytucjach publicznych Profesor Andrzej Sopoćko rozpoczą już w roku 1973, w którym został zatrudniony w Instytucie Handlu Wewnętrznego i Usług. W instytucie tym pracował do roku 1981 na stanowiskach adiunkta i docenta. Szczególna intensyfikacja działalności publicznej Jubilata ma miejsce po roku 1989, a więc po rozpoczęciu procesu transformacji gospodarki polskiej. Posiadając głęboką wiedzę ekonomiczną przyczynit się w istotnym stopniu do stworzenia ważnych instytucji gospodarki rynkowej. Jedną z najważniejszych instytucji gospodarki rynkowej, reaktywowaną już w początkowym okresie transformacji, była Giełda Papierów Wartościowych w Warszawie. Utworzona w roku 1817 warszawska giełda, najpierw działała po nazwą Giełda Kupiecka, a od roku 1873 jako Giełda Warszawska, zawiesiła swą działalność wraz z wybuchem II wojny światowej, 1 września 1939 roku. Niemal 52 lata przerwy w działalności warszawskiej giełdy stawiały przed osobami, które podjęly się jej reaktywacji, niezwykle trudne zadania stworzenia w nowych warunkach ekonomicznych mechanizmów i zasad obrotu instrumentami finansowymi. Osiągnięcie przez giełdę warszawską statusu rozwiniętej giełdy obrotu instrumentami finansowymi wymagało wielu lat i zaangażowania wielu osób. Jedną z tych osób, która przyczyniła się do osiągnięcia tego statusu jest Profesor Andrzej Sopoćko. Był członkiem pierwszej, powołanej w roku 1991, rady nadzorczej warszawskiej giełdy, 
a więc w najtrudniejszym okresie tworzenia podstaw obrotu giełdowego. Pełnił także funkcję członka sądu arbitrażowego. W latach 2003-2005, a więc w okresie dynamicznego rozwoju warszawskiej giełdy, zarówno pod względem wartości obrotów, jak i pod względem rodzajów i liczby dopuszczonych do obrotu instrumentów finansowych był wiceprezesem w jej zarządzie. Uwzględniając okresy, w których Jubilat był związany z warszawską giełdą oraz funkcje, jakie pełnił w strukturach władz giełdy, trzeba stwierdzić, że jest bez wątpienia jednym z ważnych twórców giełdy, czy też szerzej - rynku kapitałowego w Polsce.

Innym przejawem działalności Profesora związanej z tworzeniem instytucji i instrumentów rynku kapitałowego w Polsce była współpraca ze Związkiem Banków Polskich. W latach 1993-1994 był szefem zespołu przygotowującego giełdę pochodnych instrumentów finansowych. Warto zresztą dodać, że problematyka instrumentów pochodnych należy do ulubionych dziedzin spekulacji intelektualnych i praktycznych Profesora. Jego udział w tworzeniu rynku instrumentów pochodnych w Polsce zasługuje na wysoką ocenę.

W latach 1995-1997 Profesor Andrzej Sopoćko był prezesem niezwykle ważnej dla funkcjonowania gospodarki rynkowej instytucji, a mianowicie Urzędu Ochrony Konkurencji i Konsumenta. Był to ważny okres w historii instytucji dbającej o przestrzeganie warunków uczciwej konkurencji oraz ochrony interesów konsumenta w Polsce. W roku 1996 nastąpiło gruntowne przekształcenie utworzonego w roku 1990 Urzędu Antymonopolowego w Urząd Ochrony Konkurencji i Konsumenta z równoczesną zmianą jego zadań. Zadania realizowane wcześniej przez Urząd Antymonopolowy zostały poszerzone o ochronę konsumenta oraz monitorowanie pomocy publicznej, która miała istotne znaczenie w związku z rozpoczęciem starań Polski o przyjęcie do Unii Europejskiej.

W latach 2001-2003 Profesor Andrzej Sopoćko był głównym doradcą ekonomicznym w Kancelarï Prezesa Rady Ministrów. W roku 2003 pełnił także funkcję podsekretarza stanu w Ministerstwie Finansów, odpowiedzialnego za instytucje rynku finansowego, co łączyło się 
także z funkcjami: wiceprzewodniczącego Komisji Nadzoru Bankowego oraz wiceprzewodniczącego Komisji Nadzoru Ubezpieczeń i Funduszy Emerytalnych.

Oprócz omówionych wyżej funkcji w administracji publicznej Profesor Andrzej Sopoćko pełnił także ważne funkcje w organach nadzorczych w komercyjnych instytucjach rynku finansowego. Był między innymi członkiem rad nadzorczych Banku Handlowego (w latach 1996-1997) oraz Powszechnego Banku Kredytowego (w latach 1998-2001).

Z krótkiej charakterystyki działalności publicznej Jubilata wynika, że Jego działalność w tej sferze jest ściśle związana z jego zainteresowaniami badawczymi. Główne obszary działalności publicznej są związane z instytucjami rynku finansowego, a więc pokrywają się z najważniejszymi osiągnieciami w pracy naukowej. Posiadając głęboką wiedzę teoretyczną, Profesor Andrzej Sopoćko był nie tylko kompetentnym urzędnikiem, ale także osobą, której oryginalny, twórczy charakter pozwalał wnieść wiele nowych elementów do, z natury rzeczy, konserwatywnego świata urzędów. Mając wielokrotnie okazję współpracować z Jubilatem wynosimy jak najbardziej pozytywne wspomnienia z tej współpracy. Mieliśmy, i nadal mamy, okazję korzystać nie tylko z Jego wiedzy, ale także życzliwości, chęci do współpracy, do zawierania kompromisów, co przyczyniało się też do lepszego rozwiązywania problemów, za które byliśmy odpowiedzialni.

Kończąc ten krótki przegląd dokonań Profesora, wyrażamy nadzieję, że tak, jak dotąd, będziemy mieli także w przyszłości możliwość korzystać z Jego twórczej myśli i cieszyć Jego przyjaźnią. 


\section{Jan Gajda}

\section{Gajda o Sopoćko}

dorobku, walorach i zainteresowaniach Profesora Andrzeja Sopoćko współautorzy niniejszej książki napiszą lepiej i bardziej kompetentnie ode mnie. Ze swej strony chciałbym dodać drobną ciekawostkę dotyczącą Jego gustów. Pomysł przyszedł mi podczas ceremonii nadaniu przez Uniwersytet Mikołaja Kopernika w Toruniu tytułu doktora honoris causa Bobowi Engle, laureatowi Nagrody Nobla w dziedzinie ekonomii. Gdy profesor Magdalena Osińska w swej laudacji doszła do hobby laureata, słuchacze wielkim poruszeniem zareagowali na wiadomość, że jedną z jego pasji jest jazda figurowa na lodzie. Tym, którzy nie mogli uwierzyć, że wysoki (Engle ma ponad $180 \mathrm{~cm}$ wzrostu) siwowłosy mężczyzna, który przekroczył 75. rok życia może intensywnie uprawiać jazdę figurową, zaprezentowano filmik ilustrujący jego osiągnięcia w tej dziedzinie.

Profesor Andrzej Sopoćko ma równie oryginalne hobby. Interesuje się tzw. throat singing, tj. mongolskim śpiewem gardłowym (wariant śpiewu alikwotowego spotykanego w Japonii, Tuwie, Tybecie, a nawet na Sardynii). Jest to szczególny sposób śpiewania, w którym odpowiednie 
ułożenie krtani i strun głosowych sprawia, że słuchacz ma wrażenie, że słyszy kilka dźwięków (efekt jest cokolwiek chrapliwy), podczas gdy wykonawca śpiewa pojedynczy ton. Otrzymałem nawet od Profesora płytę CD z przykładami throat singing. Dla słuchacza-amatora jest to muzyka daleka od dziewiętnastowiecznego bel canto, dla Profesora - atrakcyjne hobby. Zainteresowani znajdą w internecie (por. www. wikihow.com/Throat-Sing) instrukcję, jak nauczyć się throat singingu. Przyznam, że nie sprawdzałem, czy Profesor przeszedł od słuchania do śpiewania tym stylem, muszę Go przy okazji zapytać. 


\section{Beata Glinka}

\section{Pokój obok}

Drawdopodobnie poznałam Profesora za czasów studenckich, przy1 znam jednak, że zupełnie nie pamiętam tego faktu, chyba także nie byłam nigdy uczestniczką zajęć przez Niego prowadzonych. Profesor Andrzej Sopoćko - to nazwisko było jednak mnie i moim koleżankom i kolegom z roku dobrze znane. W czasie, gdy studiowaliśmy, kierował on przecież Urzędem Antymonopolowym, przekształconym wtedy w UOKiK. Dobrze było wiedzieć, że osoby, które pracują na Wydziale udzielają się także w takiej formie na zewnątrz, współtworząc wciąż nieokrzepłą gospodarkę rynkową.

Dodatkowo, chodzity słuchy, że Profesor Sopoćko swoje stopnie naukowe (doktora i doktora habilitowanego) zrobił w bardzo szybkim tempie. Sluchy te potwierdza teraz nawet Wikipedia... Cóź, takie to czasy, że wpisując „Andrzej Sopoćko” w wyszukiwarkę, najpierw dostajemy wynik w Wikipedii, a dopiero później - na stronach Wydziału Zarządzania. To szybkie tempo nieco mnie stresowało, gdyż słyszałam o tym w kontekście planowanego pozostania po studiach na Wydziale Zarządzania. 
Lata mijały, a ja ciągle znałam Profesora głównie z opowieści, wiedziałam jednak, że współpracował z Ministerstwem Finansów i Giełdą Papierów Wartościowych. Od strony naukowej nasze ścieżki nie przecinały się wtedy zbyt często, co było naturalne, zważywszy na to, jak różne były nasze zainteresowania naukowe. Andrzej Sopoćko podejmował i podejmuje w swoich pracach naukowych problemy rynków finansowych i kapitałowych, pieniądza, zdecydowanie bardziej interesuje go skala makro, funkcjonowanie gospodarki. Jest to obszar i perspektywa odmienna od tej, którą sama przyjmuję w badaniach. Z czasem jednak okazało się, że nie przeszkadza nam to w znajdowaniu wspólnego języka nie tylko w nauce, ale także w kwestiach bardziej codziennych i przyziemnych.

Moje ścieżki zaczęły częściej krzyżować się ze ścieżkami Jubilata, gdy zostałam jego sąsiadką. Po habilitacji dostałam pokój na czwartym piętrze z widokiem na ulicę Rzymowskiego i coś, co obecnie jest parkiem i stawem. Jeszcze gdy dostawałam w użytkowanie ów pokój, parku nic nie zapowiadało, a ja miałam w głowie całkiem jeszcze świeże wspomnienia rozmaitych zwierząt, które w moich czasach studenckich zajmowały ten teren. Wkrótce zauważyłam, że na drzwiach pokoju obok wisi tabliczka z nazwiskiem Andrzej Sopoćko. Zauważyłam także, że mój sąsiad na Wydziale przebywa często, co sprawiało, że korytarzowe spotkania były na porządku dziennym. A każde takie spotkanie oznaczało żart powitalny - liczba dowcipów, które usłyszałam od mojego sąsiada jest trudna do sprecyzowania, na pewno jednak jest to wielkość trzycyfrowa.

Wtedy też zrozumiałam, że naturalnym przedłużeniem tej strony Jego osobowości są organizowane tradycyjnie podczas konferencji Wydziału Zarządzania wystąpienia kabaretowe, w których brał udział sam Profesor Sopoćko i liczne grono współpracujących z nim przy tych okazjach pracowników Wydziału. Dla dobra całej społeczności akademickiej zawsze brałam w tych przedstawieniach udział bierny, jako członek publiki. Każdego roku wystąpienie było inne, czasami przeważały w nim odgrywane $\mathrm{z}$ wielkim zaangażowaniem scenki, czasem piosenki, a czasem - monologi. 
Tak czy inaczej przez wiele lat miałam okazję dość regularnie zaczynać dzień pracy od dowcipu opowiadanego przez mojego sąsiada. Teraz, gdy rzadziej bywam na czwartym piętrze, taki początek dnia nieczęsto jest moim udziałem.

Profesor Andrzej Sopoćko nie wie jednak zapewne, że był zupełnie nieświadomym sprawcą jednego $\mathrm{z}$ najstraszniejszych dylematów, jakie miałam podczas pracy na Wydziale. Otóź kilka lat temu jedna ze znanych mi osób poszukiwała potencjalnego opiekuna pracy doktorskiej. $\mathrm{Z}$ uwagi na obszar jej zainteresowań, poleciłam właśnie Profesora. Ku mojemu zadowoleniu dość szybko porozumieli się odnośnie do tematu, a nawet koncepcji pracy. Niestety, jak to często bywa w praktyce, nawał codziennych zajęć pokrzyżował plany potencjalnej doktorantki i spowolnit, a w końcu zatrzymał pracę nad doktoratem. W ramach przeprosin za niesolidną pracę i podziękowania za interesujące i inspirujące dyskusje, owa doktorantka za moim pośrednictwem postanowiła przekazać Profesorowi czekoladki. Z przerażeniem zauważyłam, że są to czekoladki mojego ulubionego belgïskiego producenta... Ostatecznie solidność zwyciężyła i prezent z zagranicy dowiozłam na ulicę Szturmową, ale do tej pory zastanawiam się, co by było, gdyby... Pomimo upływu kilku lat, doktorantka nadal czeka na dobry moment do powrotu do nauki i swoich planów.

Choć jak wspomniałam, Profesora i moje naukowe zainteresowania są od siebie dość odległe, wielokrotnie zdarzało się nam brać wspólnie udział w rozmaitych konferencjach czy komisjach, najczęściej doktorskich, podczas których mieliśmy okazję do merytorycznych rozmów. Bez dowcipów, choć często z charakterystycznym dla Jubilata poczuciem humoru. Nie zawsze zgadzając się, ale zawsze w końcu znajdując jakiś konsensus. Niezwykle cenię sobie te okazje, podobnie jak cenię sobie takie sąsiedztwo w budynku przy ulicy Szturmowej.

Łączenie nauki z humorem, mające wyraz choćby w nieustającym opowiadaniu dowcipów, to od lat znak rozpoznawczy Profesora. Taki humor, dystans i jednocześnie otwarta postawa wobec ludzi to relatywnie rzadkie cechy. Tym bardziej należy je doceniać! 


\section{Ewa Krakowińska}

\section{Moje rozmowy z Profesorem}

Dan Profesor Andrzej Sopoćko obchodzi w tym roku piękny Jubile-
usz. Aż trudno uwierzyć, że Osoba tak petna energii oraz życiowego optymizmu osiągnęła już wiek dojrzały, niemniej jest to okazja, aby Jego przyjaciele oraz uczniowie, właśnie teraz, mogli wypowiedzieć się na temat Jego poczynań zawodowych oraz przyblizyć Jego sylwetkę jako kolegi i współpracownika.

W 1978 roku (wrzesień), jako nowo zatrudniony pracownik Wydziału Zarządzania, poznałam Pana Profesora na konferencji Wydziału Zarządzania, o ile dobrze pamiętam odbywała się ona w Miedzeszynie. Dziekan Wydziału Zarządzania przedstawił pracownikom nowo zatrudnionego Profesora, który nieśpiesznie wstał i przywitał nas uśmiechem pełnym ciepła, co wywołało moją sympatię do Pana Profesora. Moja trema przed Profesorem, w końcu byłam tylko magistrem, nie pozwoliła mi jednak porozmawiać z Nim na tej konferencji. Pan Profesor szybko tę barierę przełamał, bo już na początku roku akademickiego, gdy spotkaliśmy się na korytarzu, rozmawialiśmy ze sobą tak, jakbyśmy się znali wiele lat.

Nasza współpraca zawodowa nabrała nieco innego wymiaru, gdy zostałam kierownikiem Magisterskich Studiów Menedżerskich - zaocz- 
nych. Na tych studiach jedną ze specjalizacji była Bankowość, Ubezpieczenia i Rynki Kapitałowe, a Pan Profesor prowadził na tej specjalizacji wykłady, które cieszyły się wśród studentów dużym zainteresowaniem. Wynikało to z faktu, że Pan Profesor nawet najtrudniejsze zagadnienia zawsze kończył omawiać anegdotą lub dowcipem, co pozwalało lepiej je zapamiętać. Egzaminatorem był jednak srogim, stąd na prośbę studentów udawałam się na dyzur Pana Profesora z prośbą o kolejny termin egzaminu i choć byłam przez Niego ciepło przyjmowana, to nie zawsze udawało się wynegocjować kolejny termin egzaminu. Dzisiaj rozumiem dlaczego - kolejny termin i puste kartki egzaminu, choć ta uwaga nie dotyczy wszystkich studentów. Pan Profesor jest osobą bardzo wrażliwą i w indywidualnych przypadkach zdarzeń losowych studentów zgadzał się na egzamin ustny. Skupieni nad notatkami studenci siedzieli pod pokojem Profesora czasami bardzo długo. $\mathrm{Na}$ moje pytanie, dlaczego tak długo trwa egzamin, Pan Profesor powiedział mi, że jest to czas dla niedouczonych studentów, aby, czekając na egzamin, przyswoili sobie niezbędny materiał.

Specjalność Bankowość, Ubezpieczenia i Rynki Kapitałowe wymagała od studentów dobrych podstaw z przedmiotów ilościowych i była jedną z trudniejszych na MSM-ach, stąd zainteresowanie nią malało, i w kolejnym roku akademickim nie została uruchomiona. Pan Profesor skontaktował się ze mną w tej bolącej sprawie i wspólnie doszliśmy do wniosku, że wiedza z zakresu rynków kapitałowych może być przekazywana studentom $\mathrm{w}$ postaci wykładów do wyboru lub wykładów ogólnouniwersyteckich, tzw. OGUN-ów, które do dziś cieszą się popularnością wśród studentów. Cała ta sytuacja pokazuje, że Pan Profesor każdy problem stara się rozwiązać przez bezpośredni kontakt z wieloma osobami.

Gdy Pan Profesor rozpoczynał pracę nad nową ksiązką, każde, nawet najprostsze zagadnienie poddawał analizie. Na jednej z Rad Wydziału wspólnie z Profesorem na czynniki pierwsze rozkładaliśmy metody liczenia makroagregatów w gospodarce, aż Dziekan zwracał nam uwagę, że rozpraszamy swoimi rozmowami osoby uczestniczące w obradach. 
W 2010 roku WN PWN wydało książkę Profesora Rynkowe instrumenty finansowe, w której we wstępie Profesor napisał, że jest ona napisana dla studentów i pracowników instytucji finansowych, zrozumieją ją także osoby ze średnim wykształceniem, a elementy statystyki teoretycznej są $\mathrm{w}$ większości wyjaśnione $\mathrm{w}$ tekście i nie ma bezwzględnej potrzeby sięgania po odrębne publikacje z tej dziedziny. Kto jeszcze tej książki nie przeczytał, zachęcam do lektury - naprawdę jest zrozumiała dla każdego.

Nawet gdy Pan Profesor w kolejnej napisanej książce Mit pieniq$d z a$. Świat realny wobec iluzji pieniężnej, wydanej przez WN PWN w 2015 roku, omawia dwustrumieniowy model emisji pieniądza, w którym - po pierwsze - przywraca się bezpośrednie zasilanie budżetu w pieniądz, po drugie - następuje całkowite oddzielenie tego pieniądza pod względem regulacyjnym od drugiego strumienia, tj. trafiającego do sektora komercyjnego, przyznaje, że cała koncepcja będzie z pewnością mocno atakowana, to zawarte w krytyce argumenty już będą osiągnięciem autora książi. Profesor w swojej pracy naukowej przyjmuje, że to, co jest zakazane przez regulacje, nie musi być przeszkodą nie do przezwyciężenia. To, co stworzono, zawsze można zmienić.

Coroczny Kongres Rynku Kapitałowego, który odbywał się w auli Rady Wydziału Zarządzania (obecnie na Krakowskim Przedmieściu - UW), kończył się uroczystą kolacją w Centrum Giełdowym, Sali Notowań GPW i były to kolejne okazje do spotkań z Panem Profesorem. Na ostatniej kolacji, przy lampce wina, przy jednym stole, pracownicy Wydziału odbyli długą rozmowę poświęconą zasilaniu budżetu państwa w pieniądz. Profesor prowokował do dyskusji niezależnie od miejsca i zawsze był ciekaw argumentów uczestniczących w niej osób, gdy robiło się "gorąco", w sposób niewymuszony, rozpoczynał opowiadanie o swoim czworonożnym pupilu, a także opowiadał anegdoty, co pozwalało zneutralizować nieco atmosferę rozmowy.

Pan Profesor wychował dwoje dzieci, miałam przyjemność prowadzić z nimi zajęcia, zawsze interesowałam się ich postępami w nauce. Gdy spotykaliśmy się, najpierw padało pytanie, czy dzieciaki „dają radę”, a potem 
rozmawialiśmy już o sprawach zawodowych i miękko rozmowa przechodziła na sprawy prywatne, letni odpoczynek, spacery z pieskiem itp.

Pan Profesor był Prezesem UOKiK, współtworzył Giełdę Papierów Wartościowych, był jej wiceprezesem, był też głównym doradcą ekonomicznym premiera, wiceministrem finansów, ale zawsze znajdował czas, żeby w przyjaznej atmosferze porozmawiać, o wszystkim, ze współpracownikami, zawsze służł $\mathrm{w}$ razie potrzeby pomocą, ale najchętniej zapraszał przy każdej okazji na kawę.

Myślę, że wieloletnia praca naukowa i dydaktyczna Profesora Andrzeja Sopoćko, jego ciekawość poznawcza, zawsze stwarzają warunki - zarówno do dyskursu naukowego, jak i do łączenia dydaktyki z praktyką gospodarczą. Praca dydaktyczna Pana Profesora odgrywa znaczącą rolę w przygotowaniu kadr dla gospodarki.

Jestem przekonana, że swoje zainteresowania naukowe Dostojny Jubilat będzie nadal pogłębiał i poszerzał, że będzie w dalszym ciągu podejmował nowe wyzwania naukowe, choćby bardzo kontrowersyjne, i że będzie publikował kolejne książki, czego mu życzę z całego serca.

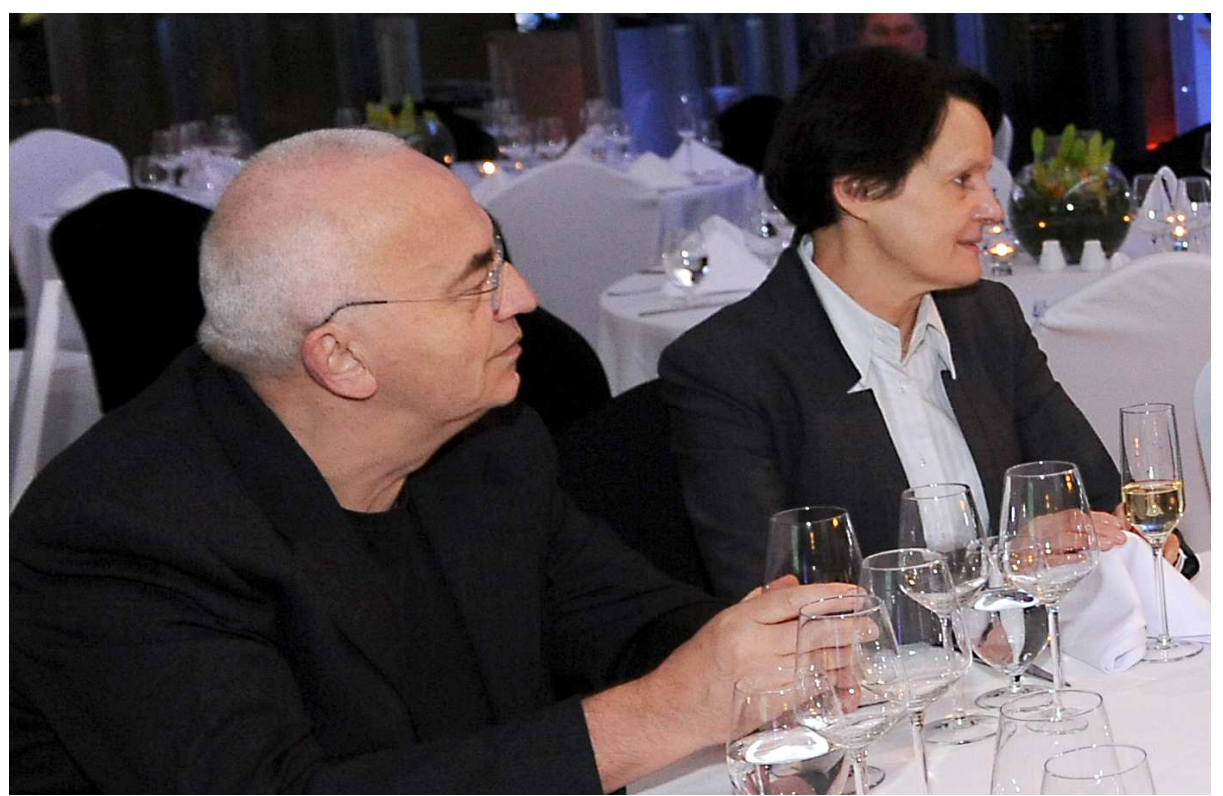

Rozmowy z Ewą Krakowińską Fot. Jerzy Krupowies. 


\section{Tomek Ochinowski}

\section{Profesorski Lubileusz $z$ naukowemy przypisamy}

o patrz Pan, Panie S. co nasz spotkało, warsiaskich rodaków,
które na Górnem Mokotowie majom przyjemnośc życia, pracy i ...inszech rzeczy używać. Spłakałem sie okrutnie ze wzruszenia jak bóbr i także samo popadłem w zadume głembokom, wypartujonc oczko wodne, co pienke budenki naszego kochanego Wydziału Zabardziarzania od starożytnech czasów odbija. A wszystko to z Pana Sianownego we własnej osobie powodu.

Jakiś czas temu nazad pewna płeć piekna, co zaszczyt minie robi, jako sionsiadka na piontem pientrze, czyli że na poddaszu, rzeczonego Wydziału się znajdując, oświeciła mnie co do jednej strasznie ważnej kwestii naukowej. I całe szenście, bo w inszem przypadku ciemnom masom bez wykształcenia salonowego mógłbym zostać słusznie nazwany.

A kwestia była taka, żeś Pan bez pucu słuszny wiek osiagnoł. $Z$ tego wienc wioskujem, jak naukowemu towarzystwu przystało, że okazaje mamy do uskutecznienia lublieusza. Na ten przykład przy kieliszku chleba możem to sprokurować. 
Najsampierw, to mnie po prawdzie wontpliowści ograneli. Bo jeszcze zeszłej jesieni, jak żeś zgodnie ze stworzonom przez Ciebie samego tradycjom w kabarecie, któren pod Twojom derekcjom na Wydziale swoje miejsce posiada, no wienc jak żeś w tem kabarecie kankana zaiwaniał, to sie zadumałem jakiem cudem takie małoletnie chłopaki za profesorów som zatrudniani ${ }^{1}$.

No ale lata lecom, choć jech nie widać jak pieniążków po wizycie na niedoległem torze konnych wyścigów. Po prawdzie to, jak przyszło co do czego, okazało sie, że w Twojem przypadku to one (lata, a także samo pieniożki na wyścigach, o czem jeszcze później zazancze) wcale tak bardzo nie polecieli. Bo przecież w porównaniu z takiem na przykład malezjeskiem premierem ${ }^{2}$, to za przeproszeniem, małoletniem pętakiem jesteś, choć rzodnowe posady to Ty już dawno masz za sobom ${ }^{3}$.

No ale płeć pienka każe, wienc i przy Twojem wieku lubileusz da się zrobić. Tem bardziej, że przy pciach pieknych, co się pod Twojem profesorskiem okiem naukowo rozwijajom trzeba być bardzo ostrożnem. Ani się nie objerzysz, a tu raz, dwa na ten przykład ministramy zostają. I to jeszcze od najbardziej czułego despektu nie tylko pożycia współmażenskiego, ale także samo i całego kraju, czyli że od pienionżków kochanych. No wienc pamientaj, Panie S. na wszelkie nieszczenście, że ja wokół tej Pani Minister to krugom na plauszkach chodziłem i po ronczkach całowałem. A także samo sie obchodze z mojom terániejszom sonsiadkom, co może sama zaświadczyć jako redahtor naczelna dzieła wiekopomnego, co z Twojej przyczyny niniejszem prokurujem. Po prawdzie to pcie brzydkie także u ciebie nieźle miewajaom, nie można powiedzieć, nawet jeśli tylko po sosniedzku majom zaszczyt Cie spoty-

\footnotetext{
1 Chodzi o kabaret od lat organizowany przez Profesora Andrzeja Sopoćko na początku roku akademickiego. Udział w nim wzięło dotąd wielu pracowników Wydziału Zarządzania UW.

2 W 2018 roku, a więc roku jubileuszu Profesora Sopoćko, premierem Malezji został 92-letni Mahathir bin Mohamad.

3 Zob. życiorys Profesora Andrzeja Sopoćko.
} 
kać. No może nie mistramy, ale póki co pod-mnistramy zostajom i to także od pieniożków, choć w mniejszem zakresie4 ${ }^{4}$.

No wienc, jak mawiali starożytne, warsiaskie przodki: „Jadziem Panie Zielonka!”. Chociaż teraz to już zaznaczać tak nie wypada. Bo w naszem czasie także samo i Zielonka ${ }^{5}$, to już nie sałata, co dryndom przez stolyce zapychał, ale płeć piekna jeśli sie rozdchodzi o Wydział Zabardziarzania. To ona nasz krótko trzyma i porzondku pilnuje, żeby profesory zawsze wszystko mieli gotowe, nawet jak sie troszkie spóźniom przez łonczenie teorii z praktykom na rzeczonych wyścigach konnych.

Lepiej wienc bedziem inne starożytne powiedzenie przytaczać: „No to, jadziem z tem koksem!". Najsampierw zmuszone jesteśmy zazanczyć, że Pan Panie S. całom swojom biografie na Górnem Mokotowie lub w jego okolicach uskuteczniasz. I to $\mathrm{Ci}$ sie bardzo chwali.

Nie liczyć tu bedziem, przy lubileuszu, niewielkich wypadów do różnych prowincjnlanych miejsc jak Paryż, Londyn czy insze amerykańskie mieściny. Bo po pierwsze i jech mieszkańcy na Twoje nauki zasłużyli, żeby wiedzieć jak z pciom pieknom i pieniążkami także samo się obochodzić. Po drugie każdemu menższczyźnie niewielkie wypady poza ukochane ojczyzne sie należom żeby jeszcze bardziej tenskił za tem miejscem, gdzie dozgonna miłość na niego oczekuje.

Znakiem tego zaczynamy od samego poczotnku. Jako małoletnie niemowle, całkiem nowe, na świat sie wyrwałeś tuż za rogiem naszego kochanego Górnego Mokotowa, w pienkem mieście Łodzi. Nie można powiedziedzieć, miasteczko odpowiedzialne, nie za małe i swój fason posiada. Precnepialna ulyca Piotrkowska tam się znajduje, gdzie różne

4 Chodzi o prof. Teresę Czerwińską z Zakładu Ubezpieczeń i Rynków Kapitałowych, kierowanym przez prof. Sopoćko, która w chwili pisania niniejszych słów (2018 r.) jest ministrem finansów i prof. Sebastiana Skuzę z sąsiedniego Zakładu, obecnie podsekretarza stanu w MNiSW.

5 Nawiązanie do gier słownych związanych z nazwiskami kadry zarządzającej Wydziałem Zarządzania UW, finezyjnie rozwijanych we wspomnianym kabarecie (zob. przypis 1). W tym przypadku chodzi o Panią Alicję Zielonkę wieloletnią kierowniczkę administracyjną Wydziału, podzielającą poczucie humoru krzewione przez prof. Sopoćko w środowisku wydziałowym. 
ławeczki inchniejszy magistrat poustawiał, żeby sławnych mieszkańców uszanować. A i przed tobom Panie S. kilku takich tam sie znajdowało, wienc $\mathrm{w}$ bardzo dobrem żeś sie towarzystwie urodził i znakiem tego towarzyska ogłada $\mathrm{Ci}$ sie już została. A także samo zainteresowania mieszane finansowo-kurturalne. Przed tobom na ten przykład Poznańszczak bawełne tam przebierał dla celów komercyjnech, Tuwimowszczak polskie kwiaty wonhał, a Rubinsztejszczczak na klawiaturze zawianiał jak tak lala. Wszystkich wymienić nie da rady. Najważniejsze, że Ty ten ogonek teraz kontynuować masz zaszczyt. Tylko łódzki magistrat z ławeczkom Sopoćko sie coś opóźnia. Ale ich krytkować nie bedziem jak na dobrych sonsiadow przystało i tego wstydu przez zaniechanie nie bedziem im wiencej wypominać. Tem bardziej, że warsiaski magistrat już jech wyprzedzil. Jak sie tylko o Twojem lubileuszu dowiedział to w trymiga oczko wodne przy naszem wydziale wykończył, choć wcześniej wieki to jem zajmało, i nie jedenom, a do jasnej anielki ławeczek poustawiał. Tylko tak się speszył, że stosownej tabliczki zapomniał sprokurować. Ale my i tak wiemy, że to wszystko ławeczki Sopoćki. Każden jeden, czy to student pentaczyna, czy któryś z szacownej kadry przed egzaminamy tam przysiada na chwile zadumy. I tak sobie odpowiedzialnie myśli, o tem, jak to dobrze, że stolyca Ciebie raz dwa przyciongła.

A dlaczego detalicznie Górny Mokotów to pewne mientkie hipoteze posiadam. Tylko, że jest ona jakościowa z natury zaznaczyć jestem najsampierw zmuszonem, żeby nasze dziewczyny i chłopaki z ilościówki teraz sie do obliczeń nie wyrwali, zamiast o Twojem lubileuszu do końca wszystko wysłuchać. Bo wtedyby za rzeczone ciemne masy sie zostali, choć z całom furom wzorów. A do tego dopuścić żadnom miarom nie możem, za bardzo ich kochamy, choć one nie zawsze o tem pamientajom.

Ta moja hipoteza to historycznom ma nature. Sprokurowałem jom w podzience Panie S., za to że, gdy właśnie historyczne podejście na naszem wydziale wskrzeszanem było, Ty żeś bardzo je wspierał, choć niejeden $\mathrm{z}$ twoich kolegów sprawe te traktował jak przysłowiowy młody wilczur jeża. $\mathrm{Za}$ to $\mathrm{Ci}$ osobiście, dozgonnie wdzienczny jestem i nigdy 
$\mathrm{C}_{\mathrm{i}}$ tego nie zapomne. Także samo dohoranty, co sie teraz starożytnościamy biznesowemi oficjalnie zajmać mogom, wiedzom, że możliwe to jest również za Twojom szanownom przyczynom ${ }^{6}$.

No to zawracamy do rzeczonej hipotezy. Bez większej wantpliowści (choć dotand to tylko moje kolegi psychologii eksperymentalne - czy, co wiesz lepiej ode mnie - niektóre ekonomisty - bez jakiegolowiek mrugnienia powieki swoje naukowe ustalenia głoszom za prawdy objawione) wychodzi na to, żeś na Górnem właśnie Mokotowie dlatego sie ustatkował, że tu, rzeczony już wiele razy w tej mowie lubileuszowej, tor wyścigów konnych jest pielengnowany. I na niem, żeś swoje kompetencje dotyczące forsy miał zaszczyt rozwijać, ze szczególnem uwzględnieniem wiedzy o niezawodności systemów finansowych. I jak żeś krugom siedemnastkom na wyścigi z wielkiem zaangażowaniem zapychał, to $\mathrm{Cie}$ dnia pewnego władze uniwersyteta naszego przyuważyli i żal odczuli, że taki zaangażowany spec od finansów na komunikacje miejskie tyle czasu marnuje. I od razu też jem się przypomniały marudzenia niektórych profesorów, że nasz uniwersytet w niekompletnem stanie się znajduje. Znakiem tego, od razu wszystkie pojeli, jak to było 200 lat temu nazad, że jak naszom uczelnie otwarli to dopiero po roku i pól pierwsze zajecnia ruszyli. Wiesz już Panie S. dlaczego tak długo się zeszło? Bo nie było podwówczas Wydziału Zabardziarzania, w ktorem honor przebywać teraz mamy. Gdyby był, to roztwarcie zajeńc po nastpench 5 latach by nastompiło, ale za to z zachowaniem procedur i dobrych praktyk które, od wieków - zawsze nowocześnie - naszych studenciaków nauczamy i które następne pokolenia także samo bendom uskuteczniać, czego jem serdecznie życzym i już sie nieco bojem.

6 Niniejszy tekst jest również niewielkim podziękowaniem Profesora Sopoćko za niezwykle miłe i skuteczne wspieranie moich skromnych działań zmierzających do reaktywowania w Polsce historii organizacji jako subdyscypliny zarządzania, która miałaby swe instytucjonalne miejsce także na wydziałach uniwersyteckich. Między innymi dzięki wsparciu Profesora Zakład Socjologii Organizacji w Katedrze Psychologii i Socjologii Zarządzania WZ UW poszerzył swoją nazwę o zwrot „i Historii Biznesu”. 
A wszytko jest możliwe dlatego tylko, że władzy uniwersyteckiej żal sie Ciebie zrobiło, bo tramwajne w tamtym czasie, to jest 40 lat temu nazad, nieregularnie posuwali. Wienc w połowie drogi miendzy Twojem mieszkaniem a wyścigamy Wydział Zabardziażania zorganizowany sie został7. Głównie po to żebyś miał gdzie swoje refleksyjne praktykie finansowe rozprzestrzeniać. I tak już zostało z czego cieszymy sie okrutnie jak norki.

A także inne kolegi na tem skorzystali rzeczony Wydział swojemy szanowanemi osobami zasilajonc. Tak, to żeś od małego dbał o innych. $\mathrm{W}$ tem temacie to już niewiele wiencej mogie napisać, bo mnie wzruszenie łzamy rzewnemy oczy zalewa.

Ale o jednej sprawie to mimo wszystko zmuszonem jestem zaznaczyć. Mnóstwo książek uczonych sprokurowałeś. Pętaki, co teraz z pieluchamy na czterech chodzom, jak niektóre jech tatusiowie przy sobocie (choć te drugie to bez pieluch), na pewno wartość Twojego pisania jeszcze nie raz bednom doceniali. Choćby dlatego, że Twoje punblikacje ładnie som wydawane, wienc na półeczce dla oka teściowej zawsze można ich poustawiać, żeby z uczonom osobom, która takie rzeczy posiada, kłócić sie nie próbowała. Ale jedna Twoja ksionżka to jeszcze ważniejsza sie okazuje, niż sennik egipski co go przed tamtom wojnom na Kierecelaku za niezłom forse upłynnić można było. Detalicznie o koncpecje mitu pieniondza się rozchodzi ${ }^{8}$. Nie masz bladego pojencia Panie S., jakie dzieło wiekopomnie tom razom uskuteczniłeś. Jak bardzo życie mokotowskich rodaków, a także samo przybyłych z innych stron, sensownem i łatwiejszem sie stało. Bo na ten przykład nad niedzielnem ranem jeden czy drugi warsisaki monż $w$ rodzinne pielesze wraca, co nieco pod tak zwanem gazem, a we wzglendzie fiansowem raczej do świetnego tureckiego podobny. Miłość dozgonna, ze sprzentem specjlistycznem na niego czeka

7 Warto przypomnieć, iz jubileusz 70-lecia życia prof. Sopoćko zbiega się z jubileuszem 40-lecia Wydziału Zarządzania i zarazem jubileuszem tyluż lat pracy Profesora na Wydziale (!). Jest więc na nim od początku.

8 A. Sopoćko, Mit pieniq̨dza, Wydawnictwo Naukowe PWN, Warszawa 2015. 
i od razu zapytauje, „Gdzie rześ łachudro nasze pieniądze roztwonił? Już ja Cie finansowej politury naucze”. A on na to: „Ubóstwo ty moje, mitamy to my nie bedziem sie zajmać, co nam niejaki profesor Sopoćko jasno wyłuszczył, lepiej dla realności pożycia małżeńskiego coś zróbmy !" I tak za jednom razom fisharmonia małżeńska jest uratowana i przyrost nautralny zadbany, a dzieciaki powstałe w takich okolicznościach musowo przyjdom z wdzięczności do Pana, Panie S. studiować, wienc o przyszłość naszego Wydziału bojać się nie musiemy. Co do sztambucha naszemu Dziekanowi łaskawemu wpisujem, ktoren zawsze z małemi przerwamy był $\mathrm{i}$ bendzie, choćby nawet nasz Wydział w zapendzie reformateroskiem kochany minister z Magnificencjom całkiem rozwiązali.

Tylko prosiemy Cie grzecznie Panie S. i Ty także samo z namy na zawsze sie zostań. O żadnej Malezji nawet nie myśl. Bo po pierwsze, jak już zaznaczałem, za młody pentak na takie ekskapade jesteś, a po drugie Wydział Zabardziażania bez Twojej sianownej osoby, to byłby jak piwo bez anholou czy też publikancje naukowe bez treści, ale za to $\mathrm{w}$ anglińskich żurnalach drukowane i punkta przynoszonce. A do tego, to już żadnom miarom dopuścić nie możem, póki żyjem. Wienc i Ty wyjścia nie masz... Żyj nam Panie S. szenśliwie i długo, a my już o nastepnych Twoiech lublieuszach naukowo dumamy. 


\section{Maciej Ramus}

\section{Kilka lekcji Andrzeja Sopoćko}

Lekcja pierwsza, czyli rzecz o cierpliwości

Koniec lat 70. ubieglego wieku, budynek SGPiS. Rzecz się dzieje Nw windzie, która z łomotem i z wyraźnym ociąganiem, bez jakiegokolwiek pośpiechu przemierza długą drogę z parteru na 3. piętro. W windzie obecni: dr Andrzej Sopoćko, osoba mi ongiś bliska, ja osobiście jako osoba towarzysząca tej osobie oraz inne osoby. Winda kołacze i stuka, więc osoby obecne $\mathrm{w}$ windzie, przestępując $\mathrm{z}$ nogi na nogę, wyraźnie się niecierpliwią, głęboko wzdychając. Wtem rozlega się głęboki głos dr. Sopoćko, który z miną sfinksa mówi - Proszę Państwa, jazda windą uczy cierpliwości.

Zapamiętałem tę lekcję o cierpliwości... 


\section{Lekcja druga, czyli rzecz o kreatywności i samodzielności}

Trzy albo cztery lata po lekcji pierwszej. Doc. dr hab. Andrzej 1 Sopoćko rozpoczyna pracę wykładowcy akademickiego w Katedrze Teorii Organizacji Wydziału Zarządzania Uniwersytetu Warszawskiego. Regularne, co tydzien, obowiązkowe spotkania pracowników (kto o tym słyszał, a gdzie wolność akademicka?) prowadzi ówczesny szef tej katedry, dziekan prof. Andrzej K. Koźmiński. Co w tym gronie ludzi zajmujących się naukowo managementem robi ekonomista Andrzej Sopoćko? Chyba to samo, co wielu innych ekonomistów w tym czasie, by wymienić wspomnianego dziekana WZ UW, nieżyących Andrzeja Zawiślaka czy Krzysztofa Lisa. Taki to był czas, że o ekonomii i gospodarce łatwiej i więcej można było mówić i pisać, używając ezopowego języka teorii organizacji...

Uczestniczę - po starej znajomości z kolegami z Zakładu Analizy Systemowej - w jednym z takich seminariów, podczas którego Andrzej dzieli się swoimi ostatnimi odkryciami. Na drodze samodzielnej analizy, nieskażonej lekturą podręczników akademickich odkrywa m.in. twierdzenia Fayola, Taylora, Adamieckiego i wielu, wielu innych. I co z tego, że uczynili to inni, wiele lat przed nim? Liczy się twórczy namysł, samodzielność i kreatywność. Przynajmniej ja tak uważam.

\section{Lekcja trzecia, czyli rzecz o cierpliwości}

zerwiec 2018 r., nowoczesny budynek B prestiżowego Wydziału
Zarządzania Uniwersytetu Warszawskiego. Rzecz się dzieje w win-
dzie, która błyskawicznie (informując roztargnionych naukowców głośno
i wyraźnie, na którym piętrze się zatrzymuje) zjeżdża z 5. piętra na 
parter. Na 3. piętrze wkracza do windy prof. dr hab. Andrzej Sopoćko. W windzie tylko nas dwóch. Andrzej, patrząc na moją zbolałą minę, pyta - Maćku, co się dzieje? Więc spuszczając wzrok na podłogę windy, z wyraźnym wstydem i głębokim poczuciem winy odpowiadam - Jestem po pisemnych zaliczeniach dla kilkuset studentów II roku, coraz trudniej mi to wszystko wytrzymać... W odpowiedzi słyszę głęboko współczujący, miękki głos prof. dr hab. Sopoćko - Maćku, studenci uczą cierpliwości.

Przypominałem sobie lekcję pierwszą...

Lekcja czwarta, czyli rzecz o kreatywności i samodzielności

W arszawa Ursynów, 2016 rok. Właśnie przeczytałem ostatnią (ale nie w dorobku Jubilata) książkę pt. Mit pieniądza. Czyta się! I zadziwia się niekonwencjonalnym podejściem oraz oryginalnością wniosków Autora. Liczy się twórczy namysł, samodzielność i kreatywność. Andrzeju Jubilacie, trzymaj się i oby tak dalej! Bieg jeszcze nieukończony... 


\section{Kazimierz Ryć}

\section{Z Andrzejem Sopoćko na eksport}

Profesor Andrzej Sopoćko jest dla mnie przede wszystkim nieoce-
nionym partnerem do dyskusji naukowych. Jest On też animatorem takich dyskusji na Wydziale Zarządzania, a Jego pozycja naukowa i działalność na wysokich stanowiskach publicznych sprawiają, że cieszy się uznaniem zarówno wśród praktyków, jak i teoretyków ekonomii. $\mathrm{Na}$ Jego zaproszenie chętnie przychodzą na Wydział, uczestniczą w dyskusjach i publikują pod Jego redakcją naukową. Życie naukowe na Wydziale bez Andrzeja byłoby uboższe.

Profesora Sopoćko znam od dawna, choć nasze relacje wzajemne były czasem z długimi przerwami w wyniku aktywności Andrzeja i mojej, również poza Uniwersytetem Warszawskim.

Poznaliśmy się we wczesnych latach 70. podczas moich odczytów na temat modelu konsumpcji i polityki rynkowej w Klubie PAX przy ulicy Wiejskiej w Warszawie. Okazał się dociekliwym młodym dyskutantem, a Jego pytania i wypowiedzi dawały prelegentowi sporo do myślenia. Mimo że podjął pracę na Wydziale Zarządzania w końcu lat 70., to nasze wzajemne kontakty były dosyć luźne z powodu wspomnianego zaangażowania nas obu poza uczelnią. 
Wyjeżdżając do pracy za granicę w Międzynarodowym Instytucie Zarządzania w Moskwie, w rozkwicie radzieckiej pieriestrojki, $\mathrm{z}$ zadowoleniem dowiedziałem się, że na stanowisku wicedyrektora w Instytucie Finansów w Ministerstwie Finansów zastąpi mnie nie kto inny, lecz Andrzej Sopoćko. Nie tylko dlatego, że stanowisko pozostanie „w rękach" Wydziału Zarządzania. Przyjeżdżając do Warszawy na macierzystą uczelnię, zawsze odwiedzałem Andrzeja w Instytucie Finansów, gdzie nasze rozmowy o tym, co dzieje się tu i tam, wymiana doświadczeń były dla mnie cenne. Chętnie czytałem Jego publikacje, sam przysyłałem materiały do publikacji w Instytucie Finansów. Po powrocie już nie z ZSRR, lecz z Federacji Rosyjskiej jeszcze przez wiele lat rosyjskiej transformacji z czasów Jelcyna byłem tam zapraszany na krótkie wizyty jako konsultant i recenzent oraz wykładowca w Międzynarodowym Instytucie Zarządzania. Jedna wizyta była szczególnie ciekawa, ponieważ dotyczyła wykładów dla rosyjskich menedżerów i biznesmenów na wycieczce statkiem z Czeboksarów, Wołgą i kanałami dorzecza Wołgi i Newy do Petersburga. Wykładałem makroekonomię i rynki kapitałowe, i w tej dziedzinie mogłem wykorzystać świeżo wydaną książkę Andrzeja: Giełda papierów wartościowych. Na statku obok mnie prowadził wykłady z etyki duchowny prawosławny.

Nasi słuchacze, mili i uprzejmi, nie byli szczególnie zainteresowani zarówno moimi wykładami, podobnie zresztą, jak i wykładami popa. Pociągało ich raczej piwo, którego duża ilość wypełniała magazyn statku. Nie było w tym nic dziwnego, bo nasi słuchacze, ludzie majętni, zapewne nie na giełdzie na początku lat 90. zgromadzili swój majątek. Tak więc, zarówno Andrzej jako autor książki, a ja jako prelegent nie przyczyniliśmy się wydatnie do rozwoju rynku kapitałowego w Federacji Rosyjskiej. Eksport myśli Andrzeja na rynek wschodni nie zupełnie się powiódt. Być może lepiej powiodło się duchownemu, wykładowcy etyki?

Nie nazbyt ukontentowany absorbcją moich wykładów przeżywałem jednak rozkosz krótkich, prawie „białych nocy” na kanałach i jeziorach dorzecza Wołgi i Newy, ciszy i słowiczych koncertów, co kompensowało 
to $\mathrm{w}$ pełni - nazwijmy - względne powodzenie przekazywania mojej wiedzy o giełdzie.

Andrzejowi w istocie wiele zawdzięczam. Jest znakomitym pisarzem, operuje dobrą polszczyzną, nie gardzi dowcipem, choć w stopniu nienaruszającym powagi publikacji naukowej. Cenię sobie z Nim dyskusje i jego erudycję. Często się spieramy, Andrzej celnie ripostuje, jednak przyjmuje też argumenty. Po każdej takiej dyskusji widzi się omawiany problem pełniej, czasem inaczej, a zawsze czuje się potrzebę dalszej wymiany opinii. Oby jak najdłużej! Tego mogę życzyć Jemu i sobie.

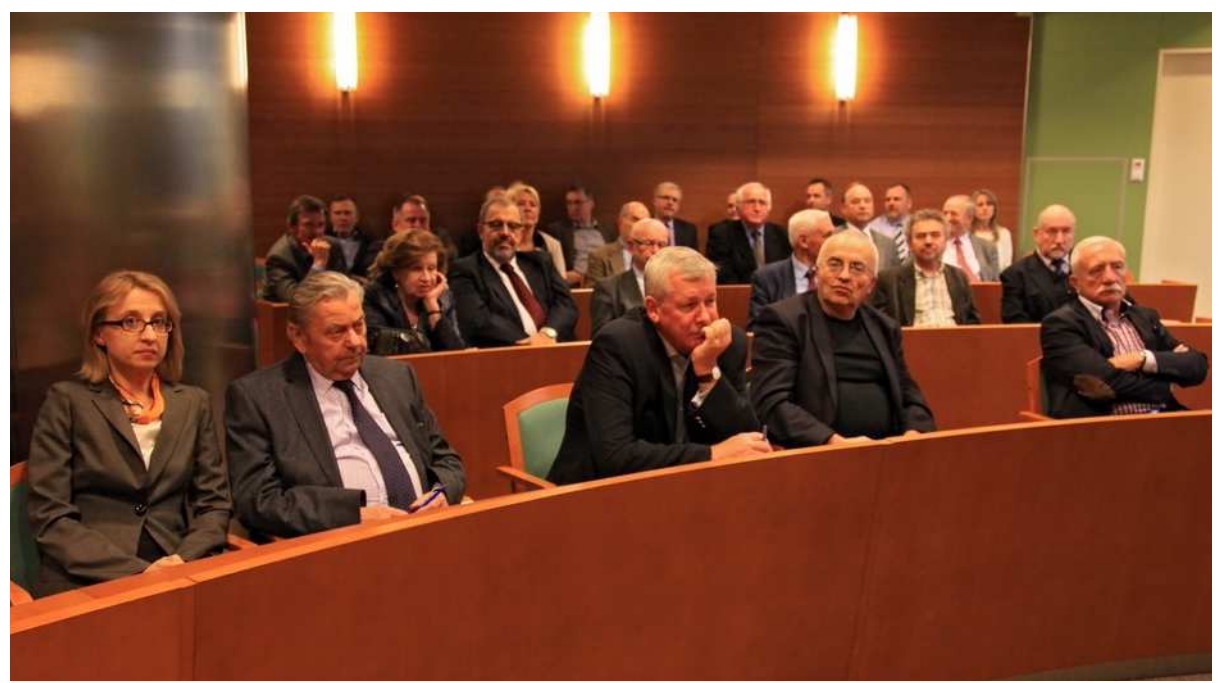

Podczas obrad konferencji w auli Rady Wydziału Zarządzania Uniwersytetu Warszawskiego. W pierwszym rzędzie od prawej: profesor A. Jaroszyński, profesor A. Sopoćko, profesor M. Górski, profesor K. Ryć, profesor T. Czerwińska, w głębi: profesorowie Wydziału Zarządzania Uniwersytetu Warszawskiego Fot. Jerzy Krupowies. 


\section{Jerzy Wierzbiński}

\section{Rzadki talent do pisania prosto o bardzo zawitych zagadnieniach}

Bertrand Russell w Portretach z pamięci, wspominając lata spędzone D $_{\mathrm{w}}$ Trinity College napisał „Wykładowcy, których moi rówieśnicy i ja sam głęboko poważaliśmy, mieli na nas wielki wpływ nawet wówczas, gdy nie mieliśmy nic wspólnego z ich pracą. Był na przykład Verrall, który specjalizował się w Eurypidesie. Miał dowcip w stylu typowo akademickim. Kiedy Granville Barter zamierzał wystawić jeden z przekładów Eurypidesa, przyjechał do Cambridge zapytać Verralla, jak wygląda chata mykeńska. Verrall miał odrzec: »Tego nikt nie wie, ale pani Harrison powie panu z pewnością«".

Dlaczego ta historia kojarzy mi się z Profesorem Sopoćko?

$\mathrm{Na}$ świecie jest wielu ludzi pokroju służącej Verralla - wypowiadających się z wielkim przekonaniem na dowolny temat.

Profesor Sopoćko jest moim starszym kolegą z innej katedry, więc niewielu jego wykładów miałem przyjemność wysłuchać, ale zawsze, gdy zabiera on głos w jego wypowiedziach, jest jakaś ciekawa i ważna myśl. 
W odróżnieniu od służącej profesora Verralla Andrzej nie waha się zadawać pytań, na które nie znamy (jeszcze?) odpowiedzi. Jest człowiekiem wielu zainteresowań i pasji, o rozległej wiedzy, nawet z dyscyplin bardzo odległych (literatura, historia).

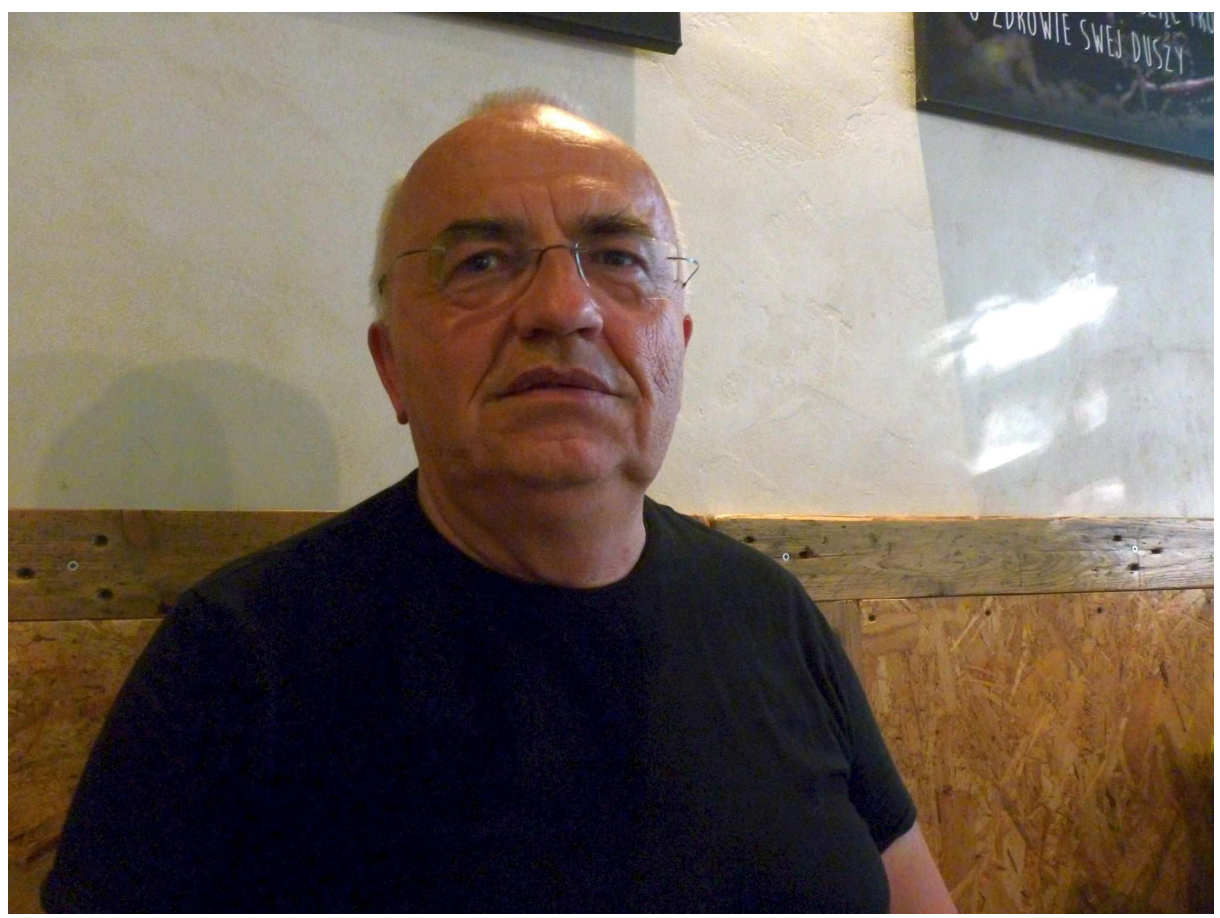

Fot. Monika Kostera.

Jest świetnym kompanem do dyskusji na bardzo różne tematy: od zastosowań statystycznych funkcji na giełdzie papierów wartościowych do kultury Wschodu.

Każdy, kto sięgnie po jego książki, zobaczy, że Profesor Sopoćko jest nie tylko erudytą, ale że posiada także rzadki talent do pisania w sposób prosty o bardzo zawilych zagadnieniach. 

Papier i pióro 



\section{Sebastian Skuza}

\section{List gratulacyjny z Ministerstwa Nauki i Szkolnictwa Wyższego}

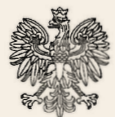 \\ MINISTERSTWO NAUKI \\ I SZKOLNICTWA WYŻSZEGO \\ PODSEKRETARZ STANU \\ Sebastian Skuza
}

Warszawa, 5 lipca $2018 \mathrm{r}$.

\section{Szanowny Pan}

Prof. dr hab. Andrzej Sopoćko

Wydzial Zarządzania

Uniwersytet Warszawski

Szanowny Panie Profesorze,

pragnę wyrazić najserdeczniejsze podziękowanie za wkład w rozwój nauki i szkolnictwa wyższego. Ponad 40-letnie zaangażowanie zawodowe Pana Profesora znajduje swoje odzwierciedlenie w Jego dzisiejszej pozycji Wydziału Zarządzania Uniwersytetu Warszawskiego, zarówno w obszarze działalności dydaktycznej, jak też naukowej.

Wkład Pana Profesora w promocję pokoleń młodych naukowców oraz pracowników rynków finansowych jest bezcenny. Osobiście jako wykładowca Akademii im. Leona Koźmińskiego oraz pracownik Ministerstwa Finansów miałem możliwość korzystania z wiedzy oraz doświadczenia Pana Profesora, szczególnie istotnego w obszarze funkcjonowania rynku kapitałowego.

Poza osiagnieciami w obszarze nauki i szkolnictwa wyższego niezmiernie istotne było zaangażowania Pana Profesora w proces transformacji ustrojowej życia gospodarczego w naszym kraju po 1989 r. Wiedza i doświadczenie Pana Profesora zdobyte podczas staży naukowych w uznanych zagranicznych ośrodkach akademickich stanowily nieocenioną wartość dodaną w tworzeniu systemu gospodarki rynkowej.

Dzisiejszy Jubileusz może stanowić okazję do refleksji i podsumowania, jednak przedwczesne byłoby stwierdzenie o uwiecznieniu kariery zawodowej Pana Profesora. Wiedza i doświadczenie Pana Profesora nadal powinny służyć nauce i szkolnictwu wyższemu, zwłaszcza w kontekście wyzwania związanego $\mathrm{z}$ aktualnie toczącym się systemowym procesem reformy tego niezmiernie ważnego obszaru.

Życzę Panu Profesorowi dalszych sukcesów zawodowych oraz wszelkiej pomyślności w życiu osobistym.

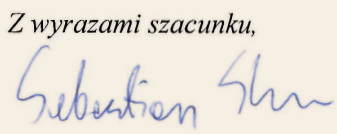




\section{Jerzy Jagodziński}

\section{Andrzej oczami redakcji}

Drofesor Andrzej Sopoćko skończył 70 lat. Takie rocznice można obchodzić w różny sposób. Jestem przekonany, iż sam Jubilat podchodzi do tej rocznicy z odrobiną charakterystycznej dla Siebie pogody ducha, dystansu i z poczuciem humoru. Chyba nikt tak jak On nie opowiada na Wydziale dowcipy, z taką lekkością i elegancją.

Tak, jako szef Wydawnictwa Naukowego Wydziału Zarządzania, pracujący do wielu lat na tym stanowisku, mogę stwierdzić z całą odpowiedzialnością, osoby z poczuciem humoru, pokonujące wszelkie dystanse z lekkością długodystansowca, a niekiedy także i bariery redakcyjne, są najbardziej pożądanymi autorami w kontekście ostatecznego efektu wydawniczego, czyli publikacji artykułu, podręcznika lub monografii naukowej. Andrzej jest jednym z tych, z którym chce się współpracować. Przede wszystkim dlatego, że jako Autor ma często coś naprawdę ważnego, oryginalnego i nieortodoksyjnego do przekazania. Opinia ta jest potwierdzana w recenzjach naukowych prac Jubilata.

Profesor Sopoćko jest wszakże uznanym badaczem i pedagogiem. Jego doświadczenie w zakresie bankowości i finansów, w dziedzinach, 
w których się specjalizuje, wykorzystał z pewnością w latach 1995-1997 jako prezes Urzędu Ochrony Konkurencji i Konsumentów, a także potem, na stanowisku wiceministra finansów czy wiceprezesa Giełdy Papierów Wartościowych. Prace naukowe, które zawierają także bagaż praktycznych, zawodowych doświadczeń, poza uczelnią, są oceniane przez czytelników bardzo pozytywnie.

Już nie pomnę, kiedy po raz pierwszy zetknąłem się z Profesorem Andrzejem Sopoćko jako autorem, współpracującym z Wydawnictwem Naukowym Wydziału Zarządzania. Jeśli myślę o zaletach, które można od razu dostrzec w Jego pracach naukowych, to z pewnością są to m.in. częste odwoływania się do literatury obcojęzycznej, głównie anglojęzycznej. Co charakterystyczne, także nierzadko odwołania krytyczne. Wydaje mi się, że w większości prac Profesor Sopoćko podejmuję tematykę trudną, ważną, ale jakże często wieloaspektową, gdzie należy poruszać się z zapałem naukowym, ale i ostrożnością sapera. Tak wyglądają Jego przemý́lenia i analizy, dotyczące tendencji na rynkach kapitałowych czy rozwoju systemów finansowych. A to wszystko dzieje się wszakże w czasie kryzysów XXI wieku. Kiedy należy szukać odpowiedzi, przecież niełatwych, dotyczących niepewności, towarzyszących rynkom i powstającym różnorodnym formom zarządzania ryzykiem.

Powstała po międzynarodowej konferencji naukowej International Conference on Management, Banking and Finance na Wydziale Zarządzania monografia pod redakcją Renaty Karkowskiej i Andrzeja Sopoćko, zatytułowana: Nowe praktyki na rynku kapitałowym, mimo że była wydana tylko w wersji e-booka, cieszy się dużym zainteresowaniem studentów i środowisk naukowych. Także dlatego, że autorzy publikacji, przedstawiając wyniki swoich badań teoretycznych i empirycznych, odnoszą się do ważnych problemów, takich jak: fuzje i przejęcia, strategie inwestycyjne, zarządzanie ryzykiem, fundusze inwestycyjne i emerytalne, czy polityka reasekuracyjna zakładów ubezpieczeń.

Profesor Sopoćko włącza się do dyskusji naukowych na temat przemian systemowych $\mathrm{w}$ warunkach globalizacji, ale także $\mathrm{w}$ odniesieniu 
do obecnych reform w naszym kraju. W publikacjach zawsze prezentuje poglądy niestandardowe, często odrębne i dyskusyjne. W księdze jubileuszowej z okazji osiemdziesiątych urodzin prof. Kazimierza Rycia w artykule Instrumenty finansowe, czy zawsze „czarne owce” prezentuje pogląd, że doświadczenia amerykańskie podpowiadają, iż tak „podejrzane" i dość powszechnie krytykowane fundusze inwestycyjne stanowią jednak istotny segment finansowania budownictwa. Jak pisze: siła narastających nieporozumień w tej sprawie stała się na tyle duża, że fundusze są raczej ofiarą, a nie źródłem nieodpowiedzialnej polityki finansowej, i moralnego hazardu jej twórców”. Jedna z konkluzji Profesora Sopoćko brzmi: finansowanie budownictwa przez fundusze inwestycyjne obniżytoby koszty finansowania budownictwa w naszym kraju. A przeniesienie przynajmniej części finansowania budownictwa z sektora bankowego na otwarty rynek finansowy, pozwoliłoby przenieść ryzyko i związaną z tym premię na rozproszony zbiór inwestorów.

W ważnej, międzynarodowej publikacji, wydanej w 2017 roku pod redakcją naukową Justina Yifu Lina i Alojzego Z. Nowaka pt. Nowa Ekonomia Strukturalna wobec krajów mniej zaawansowanych (Wydawnictwo Naukowe Wydziału Zarządzania UW), Profesor Sopoćko, odnosząc się w swoim artykule do problematyki przemian strukturalnych $\mathrm{w}$ gospodarce, dostrzega m.in. istotną wagę przewag komparatywnych w ukształtowaniu profilu gospodarki, współgrającego z globalnym postępem ekonomicznym. Wykorzystanie przewag komparatywnych daje przyspieszenie rozwoju, cały czas należy jednak ten proces kontrolować, gdyż przewagi te nie muszą być długotrwałe. Polityka gospodarcza powinna być zatem wsparciem dla tych procesów, które wzmacniają pozycję konkurencyjną kraju na rynku międzynarodowym. Służyć temu powinny działania regulacyjne i fiskalne. Ten sposób myślenia stawia Andrzeja Sopoćko w gronie tych naukowców, którzy podkreślają ważną rolę polityki gospodarczej państwa, ale już bezpośrednie wsparcie finansowe produkcji musi być bardzo ograniczone. Profesor jest więc ekonomistą o podejściu keynesowskim wobec dylematów rozwojowych, ale 
jest również ostrożny w tym, aby granice interwencji państwa nie stały w sprzeczności z efektywnością gospodarczą, racjonalnością finansową i fiskalną. Wsparcie państwa (finansowe, fiskalne, regulacyjne) powinno zatem służyć długofalowemu i zrównoważonemu rozwojowi.

W przygotowywanej przez wydawnictwo drugiej publikacji - kontynuatorce książki Nowa Ekonomia Strukturalna wobec krajów mniej zaawansowanych (tytuł tej nowej książki to New Structural Policy in an Open Market Economy) Profesor Sopoćko podejmuje m.in. problem narastających dysproporcji majątkowych i społecznych, który, jak pisze, nie daje się pogodzić z wiodącymi współcześnie wartościami, jak demokracja i solidarność społeczna. Zadaje ważkie pytanie: „Co i dlaczego w gospodarce przyczynia się do postawania dysproporcji dochodowych?". Stwierdza, że tkwią one w samym mechanizmie wytwarzania, przyczyny bogacenia się bogatych i systematycznej redukcji warstwy średniej z punktu widzenia uzyskiwanych dochodów. Szczególny nacisk w swojej analizie kładzie na badaniu udziału w narastaniu tego zjawiska procesów cyfryzacji, automatyzacji i zastosowań sztucznej inteligencji. Ale w przedstawionej analizie na podstawie danych empirycznych stwierdza: „Przemiany społeczne wydają się obecnie zmierzać dwubiegunowemu społeczeństwu, czyli takiemu, w którym istnieje grupa bogatych i reszta, bynajmniej nie uboga, jednak oddzielona od tej pierwszej istotnym przedziałem dochodów. Oznacza to redukcję klasy średniej (w statystycznym ujęciu), która w odróżnieniu od poprzednich epok staje się coraz mniej znacząca dla rozwoju cywilizacyjnego. Główną siłą sprawczą tego procesu jest trwająca obecnie rewolucja cyfryzacji i automatyzacji. Nie redukuje ona, wbrew niedawnym oczekiwaniom, liczby miejsc pracy. Następuje jednak głęboka restrukturalizacja zatrudnienia, która nadproporcjonalnie wynagradza osoby o wysokich predyspozycjach intelektualnych, znacznej wiedzy i specjalistycznych kwalifikacjach. Inni są też potrzebni, ale w tej grupie łatwo jest zastąpić jednych drugimi. Natomiast na stanowiskach o wysokich wymaganiach ten zabieg jest znacznie trudniejszy. Możliwość odejścia takich osób wywołuje zagrożenie destabilizacji procesu wytwa- 
rzania, naturalne w przypadku wypadnięcie fachowców kluczowych dla funkcjonowania fabryk i systemów świadczenia usług."

A więc Profesor Sopoćko wcale nie uważa, jak zdaje się znaczna dziś grupa ekonomistów, iż za rosnące bezrobocie odpowiadają m.in. procesy cyfryzacji i automatyzacji. Podpiera swoje konkluzje przekonującymi danymi empirycznymi. Chodzi więc Profesor Sopoćko własnymi naukowymi ścieżkami i jest w tym konsekwentny.

Chciałbym jeszcze dodać, iż studenci zagraniczni na Wydziale, ale i poza nim, korzystają z podręcznika anglojęzycznego Jego autorstwa: The Essential of Financial Markets. Handbook for Students. Żałuję, że bardzo dobre książki, takie jak: Mit pieniądza. Świat realny wobec iluzji polityki pieniężnej czy Rynkowe instrumenty finansowe Profesor Sopoćko wydał poza Wydawnictwem Naukowym Wydziału Zarządzania.

A więc, Andrzeju zaglądaj częściej z własnymi artykułami i monografiami do Wydawnictwa. You are welcome! 


\section{Grzegorz Jędrzejczak}

\section{Andrzej Sopoćko - ekonomista myślacy}

Andrzejem Sopoćko znamy się od zarania dziejów Wydziału
Zarządzania, a więc od 40 lat! Tytuł tego minieseju - Ekonomista myślacy - to w moim przekonaniu najlepsza charakterystyka Profesora Sopoćko.

„Ekonomista myślący” to jednak nie proste przeciwieństwo „ekonomistów bezmyślnych", choć niestety ten ostatni typ zdarza się nazbyt często. „Ekonomista myślący” to określenie podzbioru w ramach mojej prywatnej klasyfikacji osób zawodowo zajmujących się ekonomią:

Ekonomista analityk. Podzbiór obecnie najliczniejszy, obejmuje zdecydowaną większość ekonomistów akademickich, którzy dla budowania swojej kariery muszą regularnie publikować artykuły. To zaś oznacza wybór tematów bezpiecznych, nie kontrowersyjnych, najlepiej $\mathrm{z}$ częścią statystyczną, mieszczących się $\mathrm{w}$ jednej z wąsko określonych „ekonomik”. Ekonomista analityk jest odpowiedzią przystosowawczą do rzeczywistości współczesnego uniwersytetu z jego regułą publish or perish. 
Ekonomista teoretyk. Grupa dominująca w końcówce XX wieku, obecnie osłabła głównie w wyniku blamażu w obliczu kryzysu 2008. Okazało się bowiem, że nawet najbardziej rozbudowane i sformalizowane modele są bezradne w uwzględnieniu takich zjawisk jak regulacyjny lobbying, owczy pęd czy naiwność inwestora. Ekonomista teoretyk to wynik ambicji newtonowskich - opisania funkcjonowania gospodarki za pomocą równań, najlepiej różniczkowych, jako wielkiego mechanizmu zegarowego. Ekonomia teoretyczna czeka na swoją „rewolucję kwantową" jaka pchnęła fizykę na nowe tory w latach 20 .

Ekonomista polityk. Jest to grupa ilościowo zmienna, szczególnie liczna w czasach przełomu, kiedy starzy politycy zostają odsunięci od władzy, a nowych trzeba szukać na uczelniach. Wydział Zarządzania miał i ma istotny udział w zasilaniu szeregów posłów, ministrów, szefów instytucji państwowych oraz ich doradców. Istnieje szeroki wachlarz motywacji dla stania się ekonomistą politykiem - od szlachetnego poczucia służby, przez urok władzy, do samochodu z kierowcą. Zniechęca do tej funkcji wyjście poza ramy komfortu nauki, a w szczególności konieczność podejmowania jednoznacznych decyzji, a (nieraz) odpowiedzialności za ich rezultaty.

Ekonomista celebryta. Grupa dynamicznie rosnąca w wyniku popytu tworzonego przez gwałtowny rozwój mediów. Motywacją stania się ekonomistą celebrytą jest niewątpliwie rozpoznawalność i pieniądze, przy jednocześnie małych wymaganiach - marynarka, krawat i umiejętność przekrzykiwania innych celebrytów zaproszonych do studia (Doda, ksiądz, aktor...)

Ekonomista myślący. Grupa dosyć marginalna, choć uparcie odtwarzająca się. Ekonomista myślący wierzy w „drogę Adama Smitha” zadawania fundamentalnych pytań i dostarczania odpowiedzi na podstawie obserwacji różnorodności świata, a nie tylko wąsko rozumianych zjawisk gospodarczych. Droga ta może co prawda prowadzić na spekulacyjne manowce, jak w przypadku Marksa, ale może też prowadzić do prawdziwie istotnych i intelektualnie zapładniających stwierdzeń o gospodarce. 
Zdrowy ekosystem ekonomii wymaga istnienia wszystkich powyższych grup, we właściwej proporcji i umiejętności wspólpracy (ale to temat na odrębny esej).

Jak można umiejscowić bohatera tego minieseju w tej klasyfikacji? W przypadku Profesora Sopoćko można - w moim przekonaniu odrzucić kategorie analityka, teoretyka i celebryty.

W przypadku analityka, generalnie profesor po to jest profesorem, aby nie musieć żmudnie zbierać i przetwarzać danych, aby w końcu otrzymać trywialne, acz publikowalne rezultaty.

W przypadku drugim, teoretyka, jest to zajęcie wymagające biegłości w podręcznikowej matematyce przy jednoczesnym braku wyobraźni i chęci wyjśsia poza uproszczone założenia homo economicus.

W przypadku trzecim, celebryty, trzeba mieć krawat.

Profesor Sopoćko kilkakrotnie stawał się ekonomistą politykiem. Według Wikipedii, w latach 1995-1997 był prezesem Urzędu Antymonopolowego, przekształconego w trakcie jego urzędowania w Urząd Ochrony Konkurencji i Konsumentów. W roku 2003 pełnił funkcję podsekretarza stanu w Ministerstwie Finansów, następnie do 2005 r. zajmował stanowisko wiceprezesa Giełdy Papierów Wartościowych w Warszawie. Ta ostatnia funkcja jest mi, jako wspótzałożycielowi GPW, szczególnie bliska. Był to dobry okres dla Giełdy.

W moim jednak przekonaniu jest On z zamiłowania, temperamentu i konstrukcji intelektualnej ekonomistą myślącym. Stawianie dużych pytań i próby niekonwencjonalnych out of the box odpowiedzi jest tym what makes him tick.

Na dowód, w ostatniej ksiażce Mit pieniq̨dza Andrzej Sopoćko zmierza się, ni mniej, ni więcej, ale z pytaniem o istotę pieniądza!

W opisie wydawcy: „Pytanie »Czym jest pieniądz? «, nie jest zmartwieniem zwykłego człowieka. Dopóki nie chce zmieniać systemu finansowego, wystarczy, by go miał. Demokracja polega jednak na tym, że każdy może ten pieniądz kształtować. Każdy powinien więc znać drogę, jaką pieniądz przeszedł, od rąbanych kawałków srebra do międzynaro- 
dowego pieniądza bankowego, opartego wyłącznie na zaufaniu. O tym, jak rzadka jest to wiedza, świadczą kryzysy, wynikające z subiektywnych wizji pochodzenia sily pieniądza. Książka opisuje globalny kryzys finansowy. Profesor Andrzej Sopoćko próbuje znaleźć odpowiedź na pytanie, dlaczego stagnacja gospodarcza rozwiniętych gospodarek sięga poza system finansowy. Jego zdaniem rozwiązania, które wydawały się niedawno jedyne i ostateczne, zawiodły. Pora więc szukać nowych modeli oraz przyjrzeć się bliżej paradygmatom, które wydają się niewzruszalne. Autor proponuje wprowadzenie nowego, dla wielu kontrowersyjnego, dwustrumieniowego modelu emisji pieniądza, w którym przywraca się bezpośrednie zasilanie budżetu $\mathrm{w}$ pieniądz oraz następuje całkowite oddzielenie tego pieniądza pod względem regulacyjnym od drugiego strumienia, tj. trafiającego do sektora komercyjnego. Tego rodzaju model i wspierająca go analiza nie były dotąd stosowane $w$ literaturze monetarnej w kraju i na świecie. Autor liczy się z tym, że jego rewolucyjna koncepcja może spotkać się z krytyką, ale ma nadzieję na wartościową dyskusje."

Niezależnie od tego, czy ktoś podziela szczególowe poglądy i propozycje Profesora Sopoćko, nie ulega dla mnie wątpliwości, że powstanie nowych technologii takich jak pieniądz bezgotówkowy (plastic money) i big data; ale również nowych form gospodarowania, takich jak crowd financing i pieniądz prywatny (bitcoin), rewolucyjnie zmieni nasze rozumienie pieniądza jako środka płatniczego i przechowywania wartości.

Dyskusja na tematy podnoszone przez Profesora Sopoćko jest potrzebna chociażby dla właściwego ukierunkowania dyskusji nad przyjęciem (lub nie) przez Polskę euro. Obecnie, niestety, problem ten jest dyskutowany na poziomie marginalnie istotnych problemów technicznych i sztucznych problemów politycznych, a nie w centralnym kontekście poruszanej przez Andrzeja Sopoćko zdolności państwa do pobudzania gospodarki przez nieortodoksyjną politykę pieniężną. 
$* * *$

$\mathrm{Na}$ zakończenie osobista anegdota z Andrzejem w roli głównej. Lata temu Andrzej miał odwiedzić nas po sąsiedzku. Pukanie do drzwi i oczom moich zdziwionych, małych wtedy córek ukazuje się widok pana z wielkim psem w ramionach. Okazuje się, że pies Andrzeja bał się schodów i zamiast przymuszać go do wejścia, Andrzej przyniósł go na rękach. Ta historia została w naszej rodzinie jako przykład, jak człowiek może okazać swoje poszanowanie dla innej istoty żywej!

Andrzeju, żyj nam i myśl sto lat! 


\section{Jerzy Żyżyński}

\section{Definicja kluczem do zrozumienia}

W podtytule pierwszego rozdziału (Rodowód pieniądza) swej inspirującej, bo w pewnym sensie obrazoburczej, obalającej mity książce Mit pieniądza, Andrzej Sopoćko stawia pytanie: „Dlaczego daje się dotknąć, a nie zrozumieć?" - a wcześniej, we Wstępie, trafnie zauważa, że „Mit jest pewną nieudokumentowaną wizją pochodzenia i natury czegoś społecznie ważnego"l. Znamy się z Andrzejem szmat czasu, od pół wieku (dokładnie 51 lat). Pamiętam go jako szczupłego, wysokiego i zawsze mającego własne zdanie - lata minęty, ten okrutnik czas pozostawił mu tylko dwie z tych trzech cech - zabierając tę pierwszą. Mający własne zdanie podważa tu głęboko zakorzeniony mit: twierdzi, że nie ma żadnych przeciwwskazań dla finansowania budżetu emisją pieniądza, czyli z szerszym, jak to mówią ekonomiści, wykorzystaniem „senioratu”, czyli dochodu państwa z emisji pieniądza.

Dla niektórych jest to sprzeczne z „obowiązującą teorią”. Ale przecież w ekonomii jest tak, że na każdy temat jest pięć teorii, z których...

\footnotetext{
1 A. Sopoćko, Mit pieniądza - Świat realny wobec iluzji polityki pieniężnej, WN PWN, Warszawa 2015, s. 10.
} 
żadna nie jest prawdziwa. $Z$ prostego powodu: wszystkie przyjmują za swą podstawę jakieś założenia, które w rzeczywistym świecie czasem są, a często - na ogół - nie są spełnione. Teoria jest tylko spojrzeniem na ekonomiczną rzeczywistość z określonego punktu widzenia; można powiedzié́, że teorie ekonomii są jak dzieła sztuki, z których każde jest - jak wyraził się uczony artysta z filmu Barei - niczym zwierciadło, które można ustawiać pod różnymi kątami - te różne kąty widzenia są wyznaczone przez założenia poszczególnych teorii. Każda teoria jest zatem tylko pewnym modelowym przybliżeniem rzeczywistości; rzeczywistość zawsze bardziej lub mniej oddala się od tych założeń, a to oznacza, że teoria jest zawsze w jakimśs stopniu fikcją. Dlatego ekonomiści rozumieją, że różne szkoły ekonomiczne i wypracowane przez nie teorie dają różne spojrzenie na rzeczywistość, ale żadna nie jest do końca słuszna, żadnej nie można absolutyzować... Nie rozumie tego niestety wielu polityków i różni nawiedzeni publicyści, którzy po przeczytaniu jednej, dwóch książek autorów jakiejśs szkoły ekonomicznej przywiązują się do jednej teorï, czyniąc z niej obowiązującą ideologię - tak powstała w ekonomii swoista „poprawność polityczna".

Skoro mamy kilka teorii, to nasuwa się pytanie, która z nich jest słuszna, prawdziwa? Wynika z tego, że tak naprawdę żadna. Każda jest tylko bardziej lub mniej udaną próbą przybliżenia się do rzeczywistości. I w rezultacie, gdy przyjdzie co do czego, to okazuje się, że tej rzeczywistości tak naprawdę nikt, przynajmniej do końca, nie rozumie - i w efekcie uczeni przecierają oczy ze zdziwienia, że fakty przeczą teorii: wzrosła ilość pieniądza - a tymczasem mamy deflację; kreuje się olbrzymie ilości pieniądza w ramach QE - luzowania ilościowego a mimo to nie ma inflacji; rosną płace - i znowu wbrew teorii nie ma inflacji; "Na to pieniędzy nie ma i nie będzie” - a pieniądze jednak się znajdują.

Tak też jest z różnymi teoriami pieniądza - aż dziw bierze, że ekonomiści od lat nie potrafią uzgodnić stanowiska co do tak podstawowego 
pojęcia. Frank Decker ${ }^{2}$ wymienił trzy sposoby rozumienia pieniądza, z których wywiedziono pięć koncepcji reformy walutowej proponowanych dla systemu euro. Są to: (1) koncepcja pieniądza państwowego, gdzie pieniądz powstaje $\mathrm{w}$ wyniku decyzji o wydatkach podejmowanych przez państwo i bank centralny; (2) reguła 100\% pokrycia depozytami, która zakazuje bankom kreowania pieniądza przez tworzenie depozytów w procesie udzielania kredytów, co zwiększa rolę państwa w kreowaniu pieniądza; (3) pieniądz mający pokrycie $\mathrm{w}$ towarze, powiązany z szczególnym towarem, na przykład złotem, przez co państwo byłoby pozbawione wpływu na kreację pieniądza - iluzję takiego systemu dają tzw. kryptowaluty; (4) konkurencyjny pieniądz fiducjarny, kreowany przez niezależne banki komercyjne; (5) pieniądz oparty na własności, tworzony wtedy, gdy wierzyciel, np. bank (zarówno komercyjny, jak i centralny), emituje pieniądz dla dłużnika w zamian za zabezpieczony kredyt; w ten sposób pieniądz byłby monetyzacją (pochodną) własności, opierałby się na kapitale wierzyciela i zabezpieczeniu wniesionym przez dłuznika.

Tymczasem, tak naprawdę, kluczem do zrozumienia czegokolwiek jest właściwe zdefiniowanie danego pojęcia - dotyczy to także pieniądza. Definicja ma oddać istotę tego, co badamy, ma odpowiedzieć, czym ta rzecz jest. Jeśli teoria posługuje się właściwie rozumianym pojęciem, to dopiero wtedy mamy szansę przybliżyć się do połączenia teorii z rzeczywistością.

Tak więc źródłem, przyczyną tego, o czym pisał Sopoćko, zmitologizowania pojęć, jest brak ich właściwej definicji. Definicja pieniądza musi zatem odpowiadać na pytanie, czym pieniądz jest. Gdy sformułujemy definicję oddającą rzeczywistą naturę pieniądza, możemy określać

2 F. Decker, Proponowane reformy walutowe i eurosystemu, Biuletyn Instytutu Zachodniego, Seria Specjalna „Euro - szanse i zagrożenia”, Nr 348/2018, 20.06.2018; por. F. Decker, Central Bank or Monetary Authority? Three Views on Money and Monetary Reform, „Economic Affairs” 2017, Vol. 37, No. 3, s. 343-356. 
jego ekonomiczne funkcje i badać procesy związane z jego przepływem i gromadzeniem.

Zdefiniujmy zatem pieniądz następująco: pieniądz to prawo do nabywania dóbr i usług.

Jest to zatem nic innego jak specyficzne narzędzie, które temu, kto je posiada w określonej ilości, daje możliwość, prawo, do nabycia dóbr i usług o wartości równej ilości tych posiadanych praw. Wartość jest określona w ilości tych praw, które ktoś musi posiadać, by przejąć na własność dane dobra czy otrzymać określoną usługę. Prawo do nabywania dóbr i usług, czyli pieniądze, otrzymujemy w zamian za to, że sami daliśmy coś społeczeństwu - teraz (pieniądze są wtedy wynagrodzeniem za naszą prace) lub w przeszłości (emerytura).

Pieniądz jest więc niczym innym jak specyficznym narzędziem, które temu, kto go posiada, daje możliwość, prawo, do otrzymania określonej ilości dóbr i usług. Otrzymujemy to prawo w zamian za to, że coś daliśmy społeczeństwu. Dostajemy je w cyklu miesięcznym, tygodniowym, po każdym dniu pracy, albo bezpośrednio za wykonanie jakiegoś dzieła. Realizując swoje wydatki, czyli dokonując zakupów, przekazujemy je sprzedawcom i producentom nabywanych dóbr. W ten sposób wprowadzamy te instrumenty do dalszego obrotu: sprzedawca płaci swym pracownikom, część zachowuje dla siebie, dokonując zakupów przekazują tę część praw dalej - i tak prawa do nabywania dóbr i usług cyrkulują w gospodarce. Ilość tych cyrkulujących praw musi odpowiadać ilości wytworzonych dóbr i usług - w jaki sposób pokazał Irving Fisher w swej sławnej formule na ilość pieniądza $\mathrm{w}$ gospodarce: $\mathrm{MV}=\mathrm{PQ}$.

Ale co w gruncie rzeczy najważniejsze, uświadamiając sobie, że pieniądz jest niczym innym jak prawem do nabywania dóbr i usług, dochodzimy do oczywistego wniosku, że jego forma nie ma żadnego znaczenia - byle była skuteczna w tym sensie, że nie daje się sfałszować. Kiedyś miał formę krążków szlachetnego metalu; mógł to być woreczek 
zwany sakiewką, wypełniony złotym piaskiem lub kawałkami srebra. I dzisiaj różni nawiedzeni, a niedouczeni dyletanci kołaczą o przywrócenie pieniądza opartego na złocie albo wprost $w$ formie złotych monet - nic nie rozumiejąc, że to $w$ dzisiejszym świecie to kompletnie nie miałoby sensu.

Gdy pieniądz miał charakter kruszcowy, ludzie pozyskiwali go w najróżniejszy sposób - od zarania gospodarki rynkowej, dla przeżycia w systemie wymiany opartej na pieniądzu trzeba było w jakikolwiek sposób pozyskać te akceptowalne powszechnie prawa do nabywania dóbr i usług - pracą albo i rabunkiem. Przezorność skłaniała ludzi do odkładania tych praw na przyszłość - gromadzono monety w kuferkach i chowano w piwniczkach, zakopywano w sekretnych miejscach - i w ten sposób pieniądz wypadał z obiegu, stale ubywała z obrotu pewna ilość praw do nabywania dóbr i usług. Dla przywrócenia ich obiegowi dawne państwa wynalazły różne formy przymusowego poboru - od dziesięciny poczynając, której akceptację znajdziemy nawet w ewangeliach. Pamiętacie z sienkiewiczowskich Krzyżaków, jak pierwszym domysłem, gdy ktoś zaginął, było, „czy nie porwali go dla okupu”? - A sensem ekonomicznym było przecież nic, tylko przywrócenie obiegowi skrywanych w zakamarkach domowych pieleszy praw do nabywania dóbr i usług.

Kruszcowy pieniądz wymagał kruszcu, zatem czyż potrzeba pozyskania go nie była przyczyną wojen, akceptowanych przez państwa pirackich grabieży, niewolenia narodów, by zmusić je do płacenia lenna, a wreszcie kolonialnych wypraw po skarby wschodu i południa?

Ale, jak opisał obyczaje pieniężne na wyspie Yap Milton Fried$\operatorname{man}^{3}$, pieniądzem mógł być też zapis na wielkim kamieniu. Ten zapis dawał przecież prawa do na bywania zaspokajających potrzeby tubylców dóbr i usług. Prostym ludem byli ci wyspiarze, ale jakże innowacyjnym. Za to Chińczycy przed wiekami zauważyli, że pieniądzem może być

3 M. Friedman, Intrygujący pieniądz, Wydawnictwo Łódzkie, Łódź 1994. 
kawałek papieru i wynaleźli pieniądz papierowy... a poza tym wynaleźli proch, rakiety i fajerwerki oraz mnóstwo innych rzeczy na czele z kompasem i drukiem - tak, bo Gutenberg tylko zaadaptował chiński wynalazek dla stworzenia pierwszej przemysłowej metody druku ksiąg i gazet.

Wielkim ekonomicznym wynalazkiem okazały się banki - upowszechnione pozwalały zrezygnować z gromadzenia odłożonych praw do nabywania dóbr i usług w kuferkach i zakopywania ich w ogrodzie. Budzacy zaufanie bank mógł je przechować i wprowadzał do obrotu, udzielając kredytu na bazie zdeponowanych aktywów swych klientów. Dopiero to uwolniło państwa od problemów wynikających z ubytku pieniądza z obiegu i pozwoliło gospodarkom rozkwitać.

No i współczesność przyniosła nam pieniądz elektroniczny - czyli, jak informuje Portal Edukacji Ekonomicznej NBP, „elektroniczny zasób wartości pieniężnych w urządzeniu technicznym (...), który może być wykorzystywany do dokonywania płatności na rzecz podmiotów innych niż emitent bez konieczności angażowania w transakcję rachunków bankowych, lecz funkcjonujący jednocześnie jako z góry opłacony instrument na okaziciela". Warren Mosler ${ }^{4}$ zauważył sprytnie, że pieniądz elektroniczny jest jak dane cyfrowe na tablicy wyników meczu baseballowego. "Rząd federalny nigdy »nie ma« ani »ma« żadnych dolarów. Jest jak stadion, który »nie ma« czy »ma« worka punktów do rozdania. Gdy chodzi o dolary, nasz rząd, działając poprzez swoje agencje federalne, Bank Rezerwy Federalnej i Departament Stanu, zapisuje jedynie wynik. (...) Teraz macie już odpowiedź na pytanie: »jak za to zapłacimy? «. A brzmi ona: tak samo jak rząd płaci za wszystko, czyli zmieniając cyfry na naszych kontach bankowych." Forma pieniądza nie ma zatem znaczenia, prawa do nabywania dóbr i usług można udzielać, zmieniając cyferki na czyichś kontach - i tak przecież czyni

4 W. Mosler, 7 śmiertelnie niewinnych oszustw polityki ekonomicznej, Boiling Frog Publishing House, Warszawa 2014. 
mój pracodawca, gdy dokonuje przelewu na mój rachunek oszczędnościowo rozliczeniowy. Mosler ma rację, że „rządowi federalnemu nie zabraknie pieniędzy (...). Nie oznacza to oczywiście, że nadmierne wydatki rządowe nie spowodują wzrostu cen (inflacji). Oznacza jednak to, że rząd nie może zbankrutować i znaleźć się bez grosza." Można dopowiedzieć: jak było wtedy, gdy pieniądz był kruszcowy. Mosler, zrozumiawszy, czym tak naprawdę jest współczesny pieniądz, wyciąga oczywisty wniosek, że w systemie pieniądza elektronicznego „czeki wystawione przez rząd federalny zawsze mają pokrycie (...) i nie ma kwestii niewypłacalności."

Prawo do nabywania dóbr i usług potrzebujemy odłożyć na później i wykorzystujemy do tego banki i inne instytucje finansowe, które zapisują nasze wierzytelności, a to szczególne narzędzie potrzebne gospodarce, by wytworzone dobra i usługi zostały wykupione, przekazują w ramach swej działalności kredytowej. Ale robimy też jeszcze jedną ważną rzecz: przekazujemy je podmiotom funkcjonującym w ramach tzw. sektora publicznego, czyli państwa i innych instytucji - a więc płacimy podatki. To jest szczególnie ważny element powszechnej działalności. Oddajemy część naszych praw do nabywania dóbr i usług tej części naszej społeczności, która jest zatrudniona przez państwo i jego instytucje. To się jednak nie różni od każdej innej czynności zakupu dóbr i usług: jest to wprowadzenie do pieniądza do cyrkulacji tak jak wtedy, gdy kupujemy chleb czy kiełbasę, z tą różnicą, że o ile przy ich kupowaniu korzyść uzyskamy bezpośrednio, możemy zrobić kanapkę i zjeść śniadanie, to korzyść z płacenia podatków jest bezpośrednio niezauważalna, korzyści z istnienia państwa są bardziej - można powiedzieć - subtelne.

Ale Sopoćko zauważa jeszcze jedną ważną kwestię w rozdziale 3 swej książki: „Bogacenie się najbogatszych redukuje popyt”5. To niby trywialne, bo przecież wynika z jednego z podstawowych praw ekono-

5 Podrozdział 3.2, s. 149. 
mii - prawa malejącej, w funkcji dochodu, stopy konsumpcji. To, co trywialne jest przez wielu niedostrzegane, tak jak patrząc na las, nie widzi się rosnącego pięć metrów od nas krzaka pełnego jagód. Bogaci, bogacąc się coraz bardziej, nie wydają swych krańcowych dochodów, bo gdy na przykład komuś dochody miesięczne wzrosną z 100 tys. do 120 tys., to wydaje tyle, ile wydawał poprzednio, a z obiegu gospodarczego mogło wypaść 20 tys. zł, zwłaszcza jeśli zostały one ulokowane za granicą lub w zakupach majątkowych, które nie przełożyły się na wydatki tych, którzy ten majątek zbywali. Dzieje się coś bardzo podobnego do tego, co przed wiekami było odkładaniem majątku do kuferka: prawa do nabywania dóbr i usług wytwarzanych przez społeczeństwo wypadają z obiegu i ten szkodliwy proces powinien być jakoś skompensowany. Potrzeba wypracowania mechanizmów takiej kompensaty jest tym bardziej pilna, im bardziej powiększa się luka między wydajnością pracy a płacami - konsekwencją tego jest to, ze ilość przekazywanych społeczeństwu w formie wynagrodzeń praw do nabywania tego, co ono wytworzyło, nie nadąża za tempem wzrostu ilości dóbr wytworzonych i zdolności do zaspokajania potrzeb usługami.

I trzeba było przebłysku intuicji i zdolności do niepoddawania się stereotypom, by wpaść na to, że remedium na te szkodliwe tendencje współczesnej gospodarki może być finansowanie deficytu budżetowego emisją pieniądza. Andrzej potwierdza, że zdolności do niezależnego sposobu myślenia nie utracił i pod tym względem jest wciąż młodym człowiekiem. 



\section{Ekonomia, \\ świat wielkich finansów \\ i polityki}





\section{Teresa Czerwińska}

\section{List gratulacyjny od Ministra Finansów}

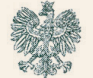 \\ RZECZPOSPOLITA POLSKA \\ MINISTER FINANSÓW
}

\author{
Warszawa, dnia 24 sierpnia $2018 \mathrm{r}$.
}

Szanowny Panie Profesorze,

$z$ okazji jubileuszu 70-lecia urodzin, proszę przyjąć serdeczne gratulacje $i$ życzenia dalszych sukcesów w pracy naukowej i dydaktycznej.

Przy tej okazji pragnę złożyć podziękowanie za trud i zaangażowanie w działania podjęte przez lata na rzecz naszej Alma Mater.

W trakcie dotychczasowej drogi naukowej i zawodowej wnióst Pan Profesor nieoceniony wkład w rozwój nauk z zakresu ekonomii. Stąd też, pozwalam sobie wyrazić nadzieję, że Pańska wiedza i doświadczenie stużyć będą kolejnym pokoleniom.

Wielce dostojny Jubilacie! Jeszcze raz proszę o przyjęcie najszczerszych życzeń zdrowia, wszelkiej pomyślności, radości i satysfakcji w życiu osobistym i zawodowym.

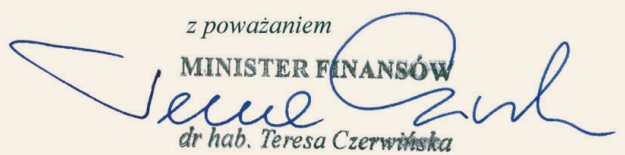

ul. Świẹtokrzyska 12,00-916 Warszawa | tel.: +48 226945555 | e-mail: kancelaria@mf.gov.pl 


\section{Marta Postuła}

\section{Cztery miesiace wspólnej przygody na Świętokrzyskiej}

W $\begin{aligned} & \text { połowie lutego } 2003 \text { r. gmach Ministerstwa Finansów przy Świę- } \\ & \text { tokrzyskiej obiegła najpierw, jak to bywa, korytarzowa, następ- }\end{aligned}$ nie oficjalnie potwierdzona 12 lutego 2003 r., nominacja od Premiera informacja, że Profesor Andrzej Sopoćko został podsekretarzem stanu. W tym czasie byłam dyrektorem Biura Pełnomocnika Rządu ds. Reformy Finansów Publicznych. Odpowiadałam za przygotowanie we współpracy i dla kierownictwa Ministerstwa Finansów na czele z wicepremierem, ministrem finansów prof. Grzegorzem W. Kołodko kompleksowy plan reformy. Była to jedna z największych przygód w moim życiu wspólnej pracy z wybitnymi ekspertami i wspaniałymi ludźmi, wśród których był Andrzej.

Osoby znające charyzmę, pracowitość i pomysłowość prof. G.W. Kołodko, wiedzą, że jak coś się dzieje pod Jego nadzorem ma się coś dziać: dobrze, szybko i z użyciem wszystkich możliwych sposób, chwil i momentów. W takim zespole pracowaliśmy wspólnie z Profesorem Sopoćko. Praca nad Programem Naprawy Finansów 
Rzeczypospolitej (PNFR) trwała nieomal non stop i nasze spotkania stawały się coraz częstsze i poznawaliśmy się coraz bardziej, aczkolwiek respekt i lekki „strach” przed wybitnym Profesorem gdzieś unosił się w powietrzu. Tak było aż do pewnego mroźnego, niedzielnego poranka. Był to kolejny weekend, który Kierownictwo Ministerstwa Finansów i osoby zaangażowane w prace nad PNFR spędzily, pracując w Skarbczyku. Po cięzkich sobotnich dyskusjach, w trakcie których omawiane były zagadnienia, za które odpowiadał Andrzej (m.in. sekurytyzacja) w niedzielny poranek wybraliśmy się na spacer ze śp. Panią Minister Haliną Wasilewską-Trenker oraz właśnie z Andrzejem. Byłam wówczas skromnym magistrem, zaledwie po studiach; uczyłam się, jak wygląda rzeczywistość nie tylko ekonomiczna, ale też polityczna, ponieważ nie można uciec od niej, pracując w sektorze publicznym na kierowniczym stanowisku.

Warto dodać, że być zaproszoną na wspólny spacer wśród tak wspaniałych ludzi, prywatnie lubiących się i myślących o zmianach w Polsce jak o przyjemnym obowiązku na rzecz wszystkich jej obywateli było ogromnym zaszczytem. W trakcie naszego leśnego spaceru dyskutowali o bardzo ważnych sprawach dotyczących szczególnego okresu, jakim był początek procesu transformacji. Opowiadali, jak istotny był to czas, jak starano się przebudować rolę państwa, a więc również zmienić spojrzenie na budżet. Chodziło o odejście od przekonania o omnipotencji państwa, zgodnie z którym, ujmując to słowami Pani Minister Wasilewskiej-Trenkner: „państwo wszystko może i dostarcza obywatelowi wszystko, co potrzebne i pożądane". Andrzej opowiadał zabawne na pierwszy rzut oka historie, pokazujące, jak stopniowo starano się przekonać polskiego obywatela, a także instytucje państwowe, że zadaniem państwa jest tworzenie warunków, w których obywatel może sam zadbać o swoje potrzeby. Państwo miało wspomagać obywatela tylko w niektórych, specjalnych sytuacjach, a ludzie tacy jak Andrzej i inni propaństwowcy, którzy w tym czasie poświęcili nieomal wszystko dla pracy dla kraju, tworzyć i wdrażać sprzyjające temu procesowi rozwiązania. 
Jednym z takich proponowanych w PNFR instrumentów była bardzo przemyślana właśnie przez Profesora Andrzeja Sopoćko część dotycząca wprowadzenia nowych instrumentów finansowych, takich jak:

- sekurytyzacja, która mogłaby być instrumentem przesuwania dochodów w czasie i przestrzeni,

- poręczenia i gwarancje nowego typu, które mogłyby wspierać małą i średnią przedsiębiorczość,

- długookresowe instrumenty finansowe, umożliwiające sięganie, na zasadzie komercyjnej, do zasobów otwartych funduszy emerytalnych po to, aby wspóffinansowały one długoterminowy cykl realizacji inwestycji infrastrukturalnych.

W tym czasie Andrzeja szczególnie interesowały zagadnienia związane z sekurytyzacją jako metodą monetyzowania przyszłych oraz zaległych przychodów i aktywów. Sekurytyzacja oparta na posiadanych aktywach polega na przekazaniu określonych należności z podmiotu inicjującego do specjalnej jednostki (spółki celowej - Special Purpose Vehicle/Special Purpose Entity), która na bazie otrzymanych należności emituje i sprzedaje papiery dłużne reprezentujące te należności.

Jeśli chodzi o sekurytyzację, to jest to niestety instrument, który nie został uruchomiony w Polsce ani w 2003 roku, ani wiele lat później. Do sprawy przyjdzie zatem powrócić w innym kontekście i czasie, gdyż jest on potrzebny. Sekurytyzacja może służyć bowiem, z jednej strony, jako instrument pozyskiwania nowych, dodatkowych środków poprzez bezpieczne formy zadłużania się pod przyszłe przychody (na przykład w okresie zmieniających się perspektyw finansowych w UE), z drugiej zaś strony może być w miarę sprawnym instrumentem oddłużania niektórych instytucji użyteczności publicznej. Moim zdaniem jednym z podstawowych problemów w zarządzaniu pieniędzmi publicznymi jest znalezienie takich rozwiązań, w których środki publiczne są wykorzystywane jak najbardziej efektywnie, czyli zgodnie z rachunkiem ekonomicznym.

Wszystkie te działania, w których tworzeniu uczestniczył Profesor Sopoćko, miały posłużý́ rozwiązaniu jednego z podstawowych proble- 
mów w zarządzaniu pieniędzmi publicznymi i znalezieniu takich rozwiązań, w których środki publiczne są wykorzystywane jak najbardziej efektywnie, czyli zgodnie z rachunkiem ekonomicznym.

Mając to na uwadze, Profesor Sopoćko skupiał się przy procesie programowania sekurytyzacji na obniżaniu kosztu emisji dla stron transakcji, np. przez wprowadzenie możliwości uzyskania gwarancji Skarbu Państwa na emitowane obligacje. Wówczas zaproponowano, że gwarancje te można będzie łączyć z rolowanymi gwarancjami instytucji europejskich, obecnie odzwierciedlonymi w ramach rozwiązań Europejskiego Funduszu Inwestycji Strategicznych (potocznie zwanego Planem Junckera). Zaproponowany na początku XXI wieku taki nowy instrument finansowy jak sekurytyzacja mógł wywrzeć znaczny wpływ na funkcjonowanie polskiego sektora finansowego, co jednak w odniesieniu do sektora publicznego się nie stało. Pomysłem Andrzeja było, aby sekurytyzacja przyniosła efekt ekonomiczny dla całej gospodarki. Udało się to dzięki działaniom Andrzeja w pionie budżetowym Ministerstwa Finansów (szczerze mówiąc była to misja „samobójcza”) i Jego znakomitym kontaktom i intelektualnemu porozumieniu z Panią Minister Wasilewską-Trenkner. Spędzali ze sobą godziny, dyskutując (ja gdzieś tam z boku temu się przysłuchiwałam), co byłoby dla Polski najbardziej korzystnym rozwiązaniem, myśląc o sekurytyzacji.

Po pierwsze, sekurytyzacja wykreuje bezpieczne, długoterminowe instrumenty finansowe, które mogą być odpowiedzią na rosnące potrzeby inwestycyjne instytucji finansowych w Polsce, a w szczególności otwartych funduszy emerytalnych (OFE). Dziś wiemy, że nie wykorzystano tak dobrego pomysłu, tylko zdecydowano się w sposób bezpośredni dokonać transferów z OFE. Nie wykorzystano ich jako swoistego rodzaju dźwigni finansowej - a szkoda.

Po drugie, sekurytyzacja powinna sprzyjać upłynnieniu kredytów, a w konsekwencji obniżeniu ich kosztów. Ponadto uruchomienie sekurytyzacji wpłynie korzystnie na rozwój i poprawę warunków działalności banków, które będą musiały w większym stopniu skoncentrować się na 
udoskonalaniu produktów bankowych oraz zdobywaniu nowych klientów. Tradycyjnie sekurytyzacja jest stosowana do obsługi zobowiązań kredytowych. Jednak w wielu krajach, zarówno w Unii Europejskiej, jak i Stanach Zjednoczonych, wypracowano również inne sposoby jej wykorzystania. W PNFR zaproponowano następujący mechanizm: specjalnie utworzonym spółkom celowym przekazuje się prawo do aktywów będącego we własności sektora publicznego, w tym prawo do przyszłych dochodów, np. przyszłych wpływów z akcyzy, opłat drogowych, a także spodziewanych transferów z funduszy Unii Europejskiej, czyli robi się swoistego rodzaju cesję przyszłych należności. Dzięki takiemu manewrowi jednostki sektora finansów publicznych otrzymałyby środki pieniężne, które mogłyby zostać przeznaczane są na inwestycje publiczne i być impulsem rozwojowym dla całej gospodarki. Zastosowanie sekurytyzacji może stać się zatem dodatkowym impulsem do ożywienia inwestycyjnego, a jednocześnie pozwalałoby zatrzymać narastanie długu publicznego, który był zmorą tamtych czasów. Rozwiązanie takie było już stosowane przez kilka krajów o wysokim poziomie długu publicznego. Sekurytyzacja była wykorzystywana jako metoda osiąnięcia dodatkowych wpływów finansowych i krótkookresowego finansowania deficytu budżetowego w okresie przed akcesją do Unii Europejskiej i w pierwszych latach członkostwa. Austria, Grecja, Finlandia i Włochy dokonały sekurytyzacji należności i aktywów takich jak wpływy z loterii (Grecja, Włochy), wpływy ze środków UE (Grecja), nieruchomości (Grecja, Austria, Finlandia) oraz nieopłacone składki na ubezpieczenie społeczne i wypadkowe (Włochy). W tym miejscu uwidocznił się bardzo mocno duch Andrzeja jako Profesora, który zarządził poszukiwać wzorów i rozwiązań stosowanych w różnych krajach oraz badać możliwość ich wdrożenia do polskich realiów.

Mamy rok 2018. Transakcje sekurytyzacji aktywów stanowią istotną część współczesnego instrumentarium inżynierii finansowej, szczególnie w rynkowym systemie finansowym. Stało to się narzędziem upowszechnianym w dobie globalizacji rynków finansowych, przyczyniając się do finansowania prywatnych i publicznych potrzeb pożyczkowych. Warto 
jednak zaznaczyć także, że transakcje sekurytyzacyjne przyczyniły się do eskalacji skutków kryzysu finansowego w latach 2007-2008, zainicjowanego na amerykańskim rynku kredytów subprime.

A co zostało z PNFR? Już w drugiej połowie 2003 r. okazało się, że mimo iż program nie zyskał zrozumienia i poparcia wśród rządzącej części klasy politycznej, wiele jego fragmentów udało się wdrożyć. Udało się też - $\mathrm{i}$ to jest jeden $\mathrm{z}$ jego skutków może niewymiernych i niemożliwy do odzwierciedlenia we wskaźnikach PKB, stworzyć grupę ludzi, którzy po 15 latach, będąc już zupełnie w różnych miejscach swojego życia zawodowego (niektórych już niestety nie ma wśród nas), potrafią dyskutować i spierać się o sprawach ważnych dla Polski, a przy tym darzą się ogromnym szacunkiem i sympatią. Miałam ogromny zaszczyt znaleźć się w tej grupie i poznać kogoś takiego jak ANDRZEJ. 


\section{Andrzej Palczewski}

\section{Od Inter-Risk do Big Data}

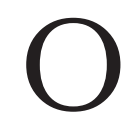

d kiedy znam Andrzeja?

To jest zwykle bardzo trudne pytanie, kiedy się zna kogoś bardzo długo. Odpowiedź na takie pytanie jest łatwiejsza, jeśli początek znajomości wiąże się $\mathrm{z}$ istotnym wydarzeniem we własnym życiu. Łatwo jest odpowiedzié, od kiedy zna się osobę, która była kolegą na studiach albo koleżanką w szkole. W przypadku mojej znajomości z Andrzejem nie jest to jednak takie proste. Nie studiowaliśmy razem, chociaż w tym samym czasie. Dodatkowa trudność w ustaleniu początku znajomości wynika z naszej wieloletniej znajomości z niedawno zmarłym Andrzejem Wieczorkiem. Odwoływanie się do wspólnego dobrego znajomego zaciera bowiem moment pierwszego spotkania, ponieważ zawsze jest pewna obawa, że poznaliśmy się znacznie wcześniej, właśnie przez tego wspólnego znajomego, a tylko ten fakt zatarł się w pamięci. Taki początek naszej znajomości z Andrzejem jest jednak bardzo prawdopodobny. Kiedy w połowie lat 90 . zacząłem interesować się matematycznymi problemami ekonomii, w tym szczególnie finansami, uznałem za konieczne pogłębienie swojej wiedzy ekonomicznej. Zwróciłem się wtedy do Andrzeja 
Wieczorka, mojego dobrego kolegi z czasu studiów matematycznych, z propozycją prowadzenia wspólnego seminarium z matematycznych podstaw ekonomii. W ramach tego seminarium zapraszaliśmy na odczyty wielu aktywnie pracujących naukowo ekonomistów. Nie mogło wśród nich zabraknąć Andrzeja Sopoćko, znanego ekonomisty a jednocześnie dobrego znajomego Andrzeja Wieczorka. Kiedy to jednak miało miejsce, dokładnie nie potrafię sobie przypomnieć. W każdym razie było to dobrze ponad 20 lat temu.

\section{Nasze wielkie wspólne przedsięwzięcie}

Moja znajomość z Andrzejem miała przez pewien czas charakter czysto towarzyski - wspólna kawa lub lunch. Ale w pewnym momencie, gdzieś w drugiej połowie lat 90., Andrzej postanowił wciągnąć mnie do współpracy nad problemem zarządzania portfelem obligacji Skarbu Państwa.

Pomysł analizy rynku instrumentów stopy procentowej oraz wykorzystanie tej analizy do zarządzania inwestycjami w obligacje skarbowe Andrzej rozważał już od pewnego czasu. Efektem było opracowanie przez niego programu w systemie Excel, który miał wspomagać takie zarządzanie. Andrzej chciał, aby takie narzędzie wspierania decyzji inwestycyjnych zaimplementować w banku PBK, w którym był wtedy głównym ekonomistą. Rozmowy z dilerami z banku sugerowały rozbudowę programu o dodatkowe moduly analizy. Andrzej uznał, że moja wiedza matematyczna może być przydatna w pracy nad stworzeniem tych nowych modułów. Dalsze rozmowy z potencjalnymi uzytkownikami systemu pokazały, że celowe jest budowanie samodzielnego systemu (a nie nakładki na Excel), który mógłby być integrowany z innymi systemami informatycznymi pracującymi w banku. W efekcie powstał pomysł stworzenia samodzielnego systemu analizy polskiego rynku 
instrumentów dłużnych. Od tego momentu stało się jasne, że nie jest to przedsięwzięcie, które może zrealizować dwóch uniwersyteckich profesorów. Należało stworzyć firmę, której zadaniem byłoby rozbudowanie początkowego pomysłu Andrzeja do rozmiarów samodzielnego systemu decyzyjnego. Tworzenie firmy wymagało rozwiązania dwóch podstawowych problemów: znalezienie środków na działalność oraz znalezienie ludzi, którzy by tę działalność prowadzili. Te zadania podzieliliśmy między siebie: Andrzej nakłonił dr. Stanisława Nowaka, prowadzącego firmę Towarzystwo Usług Ubezpieczeniowych TUR, do uruchomienia firmy jako firmy córki tego Towarzystwa, a ja znalazłem młodych informatyków, którzy byli gotowi pracować nad budowaniem systemu zarządzania inwestycjami na rynku papierów dłużnych.

Tak powstała Korporacja Badań nad Ryzykiem Inwestycyjnym Inter-Risk, której Profesor Andrzej Sopoćko został prezesem. Potem były dwa lata intensywnej pracy nad budową systemu. Ze strony Andrzeja wymagało to przełożenia wiedzy ekonomicznej na język na tyle precyzyjny i jednoznaczny, aby nasi informatycy mogli stworzyć odpowiednie algorytmy oraz zaimplementować je do systemu. Moim zadaniem było znajdowanie właściwych narzędzi matematycznych pozwalających prowadzić efektywne obliczenia potrzebne w różnych analizach. Wymagało to od nas obu zgłębienia różnego typu konwencji funkcjonujących na rynku finansowym, a następnie przełożenia ich na język, który byłby zrozumiały dla zatrudnionych informatyków. Na tym wczesnym etapie rozwoju polskiego rynku finansowego wiele $\mathrm{z}$ obowiązujących konwencji było wprost przenoszonych z rozwiniętego rynku europejskiego, czasem z dokonywanymi ad hoc adaptacjami. Wszystko to było słabo udokumentowane - po prostu praktycy działający na rynku wiedzieli, jakie zasady obowiązują. W efekcie tylko dzięki temu, że Andrzej pracował jednocześnie w banku mogliśmy dotrzeć do osób, które realnie znały aktualnie obowiązujące konwencje (na dodatek znały daty, w których obowiązujące konwencje były zastępowane innymi). 
Zasadniczym pomysłem Andrzeja było stworzenie systemu optymalnych decyzji inwestycyjnych na rynku instrumentów dłużnych, który pozwalałby na uwzględnienie prognoz inwestora dotyczących przyszłego zachowania rynku. Takie systemy optymalnych inwestycji były od pewnego czasu tworzone na rynku akcyjnym. Były to modele, które rozszerzały klasyczny model Markowitza o możliwość włączenia prognoz inwestora - można tu wymienić model Treynora-Blacka czy też powstały w firmie Goldman-Sachs model Blacka-Littermana. Na rynku instrumentów dłużnych podstawowym modelem optymalnego inwestowania był jednak model oparty na czasie trwania (duration), czasem rozszerzany o wypukłość (convexity). Modele takie bazowały wyłącznie na historycznych danych rynkowych i nie było w nich miejsca na włączenie prognoz inwestora na temat przyszłego zachowania rynku. Pomysł Andrzeja polegał na wprowadzeniu do modelu możliwości tworzenia przez inwestora scenariuszy zachowania przyszłych stóp procentowych. Istotą modelu było prognozowanie rzeczywistej rentowności instrumentów dłużnych w oparciu o wybrany scenariusz. Ten zasadniczy pomysł wymagał $\mathrm{w}$ wielu punktach szczególowego dopracowania lub dostosowania do oczekiwań inwestorów. Wiele potrzebnych analiz wymagało też znalezienia nowych narzędzi matematycznych (to była najczęściej domena mojego udziału w projekcie). Wreszcie chodziło o wygodne dla użytkownika przedstawienie wyników analiz (tym zajmowali się nasi informatycy).

Po około dwóch latach pracy powstała pierwsza robocza wersja Systemu Planowania i Weryfikacji Inwestycji LIBRA. Celem systemu było zarządzanie inwestycjami na rynku papierów dłużnych oraz poszukiwanie najlepszych możliwości inwestycyjnych. Już wstępna wersja systemu pozwalała analizować inwestycje na międzybankowym rynku polskich papierów dłużnych o stałym kuponie $\mathrm{i}$ inwestycje $\mathrm{w}$ bony skarbowe w oparciu o kwotowania na rynku wtórnym. System działał $\mathrm{w}$ połączeniu online z dystrybucją informacji rynkowych, co pozwalało uzyskać bogaty zestaw analiz pojedynczych papierów, otwartych pozy- 
cji oraz całego rynku. Istotnym komponentem systemu była możliwość tworzenia scenariuszy zachowania rynku i rozważanie różnych wariantów inwestowania. System pozwalał na bieżąco analizować zachowanie stóp procentowych oraz monitorować i analizować ryzyko inwestycyjne. Zewnętrznym elementem w stosunku do systemu informatycznego były systematycznie uaktualniane prognozy podstawowych parametrów finansowych oferowane przez naszą firmę.

Jak zostało wspomniane, firma Inter-Risk razem z systemem informatycznym oferowała także zestaw standardowych prognoz stóp procentowych na polskim rynku. Prognozy te miały być przykładem tworzenia scenariuszy, a jednocześnie pozwolić mniej doświadczonym użytkownikom na pełne wykorzystanie możliwości systemu. Problem tworzenia wiarogodnych prognoz był dla nas bardzo ważnym elementem oferowanego produktu. Było sprawą całkowicie oczywistą, że odpowiedzialność za tworzenie prognoz spadła na Profesora Andrzeja Sopoćko. W końcu on był jedynym w naszym gronie w pełni profesjonalnym ekonomistą. Muszę przyznać, że Andrzej przez długi czas wywiązywał się z tego zadania nadspodziewanie dobrze. Aby zadania tego nie czynić nadmiernie skomplikowanym, Andrzej ograniczył się do prognozowania stóp procentowych ustalanych przez Radę Polityki Pieniężnej. Uznaliśmy, że znając stopy ustalone przez RPP, można z dużą dozą dokładności przewidzieć ruch pozostałych stóp procentowych na rynku. Te prognozy Andrzej opracowywał przez około rok, osiągając zaskakującą wręcz zgodność z decyzjami RPP (odchylenie prognozy od rzeczywistej decyzji nie było nigdy większe niz 0,5\%). Zasługuje to na szczególne podkreślenie, bo prognozy były przedstawiane zwykle z miesięcznym wyprzedzeniem w stosunku do decyzji RPP (czytelnikowi należy przypomnieć, że w tamtym okresie, czyli latach 2000-2002 stopy procentowe w Polsce były na poziomie rzędu $10 \%$, więc błąd $0,5 \%$ był rzeczywiście bardzo mały).

Po opracowaniu roboczej wersji systemu LIBRA rozpoczęliśmy poszukiwanie potencjalnych użytkowników zainteresowanych imple- 
mentacją systemu. Było to związane także z koniecznością pozyskania dalszych środków na rozwój firmy. Wymagało to wielu rozmów z potencjalnymi zainteresowanymi, połączonych z prezentacją systemu. Był to rodzaj zajęcia dość nietypowy dla uniwersyteckich profesorów. Staraliśmy się robić to jak najlepiej, czasem razem, czasem osobno, często wspierani przez pracujących nad systemem informatyków. W ramach tej działalności odbyliśmy dziesiątki rozmów handlowych i wykonaliśmy podobną liczbę prezentacji. Pokazywaliśmy system w wielu bankach, państwowych i prywatnych, firmach ubezpieczeniowych, a także różnych państwowych agencjach. System spotykał się ze sporym zainteresowaniem ze strony naszych rozmówców, ale finalnie nie udało się nam nikogo zainteresować jego wdrożeniem (chociaż niektóre negocjacje były już dość zaawansowane). Kiedy patrzę na te starania z perspektywy czasu, wydaje się, że nasze przedsięwzięcie było trochę przedwczesne z punktu widzenia rozwoju przedsiębiorczości w Polsce. Nasza firma była typowym przykładem start-up’u, czyli jedną z takich firm, które dzisiaj traktowane są jako potencjalny nośnik innowacyjnych rozwiązań. Ale blisko 20 lat temu było to zjawisko zupełnie nieznane na polskim rynku. Wiele dużych instytucji nie miało świadomości, że mała firma bez doświadczenia może im zaoferować coś, czego nie dostaną od dużego dostawcy. Jednocześnie mniejsze firmy oraz agencje rządowe nie w pełni rozumiały jeszcze korzyści wynikające z efektywnego zarządzania własnymi środkami. Z drugiej strony na rynku brakowało firm typu venture capital, które były gotowe inwestować własny kapitał w rozwój start-up'u, licząc na przyszły potencjalny zysk. Wreszcie, w przypadku firm córek dużych firm zagranicznych, brakowało odwagi polskich menedżerów na inwestowanie w powstałe na polskim rynku innowacje.

W efekcie po dwóch latach intensywnej pracy firma Inter-Risk zakończyła działalność. $Z$ mojego punktu widzenia nie był to jednak czas stracony. Nie tylko nauczyłem się wiele na temat praktycznych aspektów funkcjonowania rynku finansowego, ale także zyskałem spore doświadczenie w kontaktach z biznesem. Dla Andrzeja nie było to 
zapewne aż tak nowe, ponieważ miał już doświadczenie w pracy na rynku finansowym. Okres działalności firmy był także okazją do znacznego zacieśnienia kontaktów z Andrzejem. Nasza codzienna współpraca w ramach firmy zamieniła się w bliskie relacje także poza firmą, które utrzymujemy ze sobą do tej pory.

\section{0 lat później}

Po okresie intensywnej współpracy w ramach firmy Inter-Risk nasze kontakty zawodowe stały się mniej intensywne. Bezpośrednio po zakonczeniu działalności firmy Andrzej objął szereg stanowisk w administracji rządowej, w tym stanowisko wiceministra finansów, a następnie został wiceprezesem Giełdy Papierów Wartościowych w Warszawie. Siłą rzeczy nasze kontakty ograniczyły się do sporadycznych spotkań towarzyskich. Kontaktom zawodowym nie sprzyjała także moja intensywna praca nad kolejnymi grantami związanymi z modelowaniem rynku finansowego. Ale nawet w tym okresie pozostawaliśmy w ciągłym kontakcie. Pamiętam, jak Andrzej z radością korzystał z kalkulatora dla pochodnych instrumentów finansowych, jaki opracowywałem wspólnie ze studentami matematyki finansowej na UW. Jego związek z tym projektem nie ograniczał się tylko do korzystania z możliwości obliczania cen, jakie stwarzał kalkulator, ale także obejmował analizę poprawności jego działania. Ta zewnętrzna kontrola poprawności okazała się zresztą bardzo owocna, bo doprowadziła do wykrycia błędów w programie. Wykrycie, a potem usunięcie tych błędów, było niewątpliwą zasługą Andrzeja. Z kolei kilka lat później Andrzej starał się wciągnąć mnie w projekt grantowy dotyczący równowagi monetarnej. Główna idea Andrzeja polegała na częściowym odejściu od sterowania równowagą systemu finansowego przez regulację płynności sektora bankowego na rzecz bezpośredniego zasilania konsumpcji publicznej. Przymierzaliśmy się przez pewien okres 
do uruchomienia tego projektu, ale ponieważ jednocześnie miałem na głowie kierowanie projektem dotyczącym rozbudowania modelu optymalnego inwestowania na rynki, na których stopy zwrotu nie mają rozkładu normalnego, w efekcie przestałem uczestniczyć w tym projekcie. Do ponownej bliskiej współpracy zawodowej wróciliśmy dopiero ostatnio. Stało się to za sprawą projektu związanego z badaniem hipotezy efektywnego rynku na bazie danych z GPW. Trudno na razie przewidzieć, jakie będą efekty naszej pracy. Ponieważ badamy dane obejmujące wszystkie składane zlecenia, oznacza to przetwarzanie ogromnych zbiorów danych. W efekcie istotnym składnikiem podjętej działalności jest informatyczna obróbka uzyskanych danych. Ponownie, jak w przypadku firmy Inter-Risk, Andrzej jest odpowiedzialny za ekonomiczny sens prowadzonych analiz, a ja odpowiadam za aspekty informatyczne projektu, co oznaczało między innymi pozyskanie współpracownika biegłego informatycznie. $\mathrm{Na}$ razie patrzymy w przyszłość z optymizmem, licząc, że uda się nam coś ciekawego w tym projekcie uzyskać. Jest to też dla mnie dodatkowa okazja, aby częściej spotykać się z Andrzejem i dyskutować o różnych interesujących nas sprawach (nie tylko dotyczących ekonomii i rynków finansowych). 


\section{Bogdan Szafrański}

\section{Inauguracja GPW \\ $w$ Warszawie $-w$ Kalifornii}

$\triangle_{\text {jeden z pierwszych zajął się odtwarzaniem wiedzy o podstawach }}^{\text {ndrzej Sopoćko, po politycznym przełomie roku } 1989 \text { w Polsce, jako }}$ funkcjonowania i mechanizmach rynku kapitałowego. Była to wówczas dziedzina kompletnie zaniedbana, niepotrzebna w czasach gospodarki centralnie planowanej. Blisko pięćdziesięcioletnia przerwa w istnieniu polskiego rynku kapitałowego $\mathrm{w}$ rezultacie spowodowała nieuniknioną pustkę prawno-instytucjonalną. Brakowało zarówno doświadczeń, jak i kompetentnej i aktualnej wiedzy fachowej. Aby sprawnie przejść od socjalizmu do kapitalizmu - systemu gospodarki wolnorynkowej, należało stworzyć od podstaw jego podstawowy filar i regulator - giełdę papierów wartościowych.

W celu wspomożenia kształcenia przyszłych pracowników tej instytucji, a co ważniejsze, również przyszłych jej użytkowników, tj. inwestorów oraz obsługujących ich zlecenia maklerów i wspomagających w możliwie trafnym wyborze doradców inwestycyjnych, Andrzej Sopoćko podjął się 
napisania książki pt. Giełda papierów wartościowych, której pierwsze wydanie ukazało się na początku 1991 roku. Autor opisywał w niej miejsce giełdy w strukturze gospodarki rynkowej, podstawowe kategorie papierów wartościowych, podstawowych uczestników rynku kapitałowego, organizację giełdy, strategie inwestycyjne, a również podstawy transakcji terminowych. W dniu dzisiejszym, trudno jest spotkać wśród pierwszych uczestników rynku kapitałowego w Polsce kogoś, kto nie czytałby tej pracy Andrzeja Sopoćko. Dla wielu było to źródło podstawowej wiedzy o raczkującym rynku kapitałowym, pomimo swej zwięzłości czy czasem niezamierzonych niedokładności. Były one wynikiem, jak autor przyznał, braku możliwości kompetentnej dyskusji z innymi znawcami tematu w Polsce, bo ich jeszcze po prostu nie było. A samo tłumaczenie zagranicznych źródeł niewiele pomagało, bo w tłumaczeniu pojawiały się też niedokładności wynikające choćby z braku jednolitej i powszechnie rozumianej terminologii, która dopiero się tworzyła, właśnie m.in. poprzez pisanie tych nowatorskich książek, jak ta napisana przez Andrzeja Sopoćko.

Doceniając wkład Andrzeja Sopoćko w odtwarzanie wiedzy o rynku kapitałowym, powołano go do składu pierwszej rady nadzorczej warszawskiej Giełdy Papierów Wartościowych. Tworzenie, a właściwie odtwarzanie zrębów polskiego rynku kapitałowego odbywało się błyskawicznie. W dniu 22 marca 1991 r. została uchwalona przez Sejm ustawa Prawo o publicznym obrocie papierami wartościowymi i funduszach powierniczych. Ustawa regulowała podstawy prawne do organizacji i funkcjonowania głównych instytucji rynku kapitałowego: giełdy, domów maklerskich, funduszy powierniczych oraz Komisji Papierów Wartościowych - organu administracji rządowej regulującego i promującego rynek papierów wartościowych. Podstawową instytucją miała być giełda, która według ustawy powinna zapewniać: koncentrację podaży i popytu na papiery wartościowe dopuszczone do obrotu giełdowego w celu kształtowania powszechnego kursu, bezpieczny i sprawny przebieg transakcji 
i rozliczeń oraz upowszechnianie jednolitych informacji umożliwiających ocenę aktualnej wartości papierów wartościowych dopuszczonych do obrotu giełdowego.

Niecały miesiąc później, 12 kwietnia 1991 r., Minister Przekształceń Własnościowych i Minister Finansów reprezentujący Skarb Państwa podpisali akt założycielski Giełdy Papierów Wartościowych w Warszawie. Już cztery dni później, 16 kwietnia odbyła się pierwsza sesja giełdowa z udziałem 7 domów maklerskich, na której notowano akcje 5 spółek Tonsilu, Próchnika, Krosna, Śląskiej Fabryki Kabli i Exbudu. Transakcji było niewiele, bo wpłynęło jedynie 112 zleceń kupna i sprzedaży, a łączna wartość obrotu giełdy wzrosła do 1.990 zł.

Ten obfitujący w ważne wydarzenia dla rozwoju polskiego rynku kapitałowego miesiąc kwiecién, Andrzej Sopoćko spędził jednak w dalekiej południowej Kalifornii. Pierwotnym motywem jego pobytu tam była możliwość wsparcia pomysłu utworzenia wówczas na terenie Polski kopii tajwańskich Stref Produkcji Eksportowej (Export Processing Zones EPZs). Pomysłodawcami tej idei, posiadającymi dodatkowo konkretne plany i wiedzę, jak takie strefy efektywnie utworzyć; co więcej mającymi robocze kontakty z tajwańskimi źródłami nie tylko wiedzy praktycznej, ale i dużego kapitału, byli emigranci wietnamscy w USA - byli ministrowie ostatniego rządu w Sajgonie. Po ewentualnym zakończeniu wojny tam, chcieli odbudowywać kraj za pomocą stworzenia EPZs. Planu tego nie udało się zrealizować, bo wojna została przegrana w 1975 r., ale po roku 1989 zidentyfikowali szansę w Polsce i na Węgrzech. Później utworzone (od 1994 r.) i istniejące do dziś w Polsce Specjalne Strefy Ekonomiczne sa pewnym wariantem tego pomysłu.

W rozważanie szans i możliwości takiego projektu w Polsce zaangażowany był też profesor Andrzej K. Koźmiński, który corocznie przyjeżdżał do Los Angeles wykładać na UCLA (University of California Los Angeles), a potencjalnym patronem mógł zostać ówczesny Minister Przemysłu profesor Andrzej Zawiślak. Pomysł pozostał na papierze, ale 
pobyt w południowej Kalifornii Andrzej Sopoćko miał ciekawy, również z naukowego i poznawczego powodu.

Po pierwsze, udaliśmy się na UCI (University of California Irvine), na którym wcześniej studiowałem zarządzanie, a konkretnie zarządzanie finansami na Merage School of Business i uzyskałem tytuł MBA (Master of Business Administration) w 1990 roku. Kilku profesorów, z którymi mieliśmy okazję się spotkać, miało istotny, a mało znany wpływ na transformację gospodarczą w Polsce. Profesor Judy Rosner w roku 1988 prowadziła zajęcia dotyczące prywatyzacji. Na pierwszym wykładzie zapytałem ją, czy dla mnie, jako studenta z Polski, z Warszawy taki przedmiot ma sens. Odpowiedziała, że dla Amerykanów to tylko ciekawostka, ale dla kogoś z Bloku Wschodniego to może wkrótce być bardzo pożyteczna wiedza. Podręcznikiem była książka pt. Privatization. The Key to Better Government E.S. Savasa z 1987 r. (przetłumaczona i wydana w roku 1992 po tytułem Prywatyzacja. Klucz do lepszego rzadzenia). Prywatyzacja w Polsce niewiele jednak przypominała amerykański wzorzec, niemniej dyskusja o różnicach i ich przyczynach wzbogacała wiedzę.

Gdy Krzysztof Lis został Pełnomocnikiem Rządu ds. Przekształceń Własnościowych w roku 1989, poinformowałem o tym fakcie profesor Judy Rosner. Zapytała, jak UCI mógłby pomóc. Krzysztof Lis, któremu przekazałem pytanie, bez wahania odpowiedział - wysyłając książki o finansach, rynku kapitałowym, instrumentach finansowych. Razem z Judy Rosner udaliśmy się do Dziekana Merage School of Business (wtedy jeszcze pod nazwą Graduate School of Business UCI) Dennisa Aignera. Ten ku mojemu zaskoczeniu pokazal, że w jego gabinecie jest kilka tysięcy podręczników przysłanych przez wydawców do zapoznania się z nimi. Wybrałem około pięćdziesięciu, które zostały wysłane do Krzysztofa Lisa na Świętokrzyską. Lis wezwał swoich pracowników, aby wybrali dla siebie książki. Tak wiedzę m.in. zdobywali Lesław Paga, Wiesław Rozłucki i inni polskiego rynku kapitałowego. Jeden z pierw- 
szych współpracowników Krzysztofa Lisa pamiętał o tej przesyłce i tak ją skomentował: „Wtedy to Rozłucki nie rozróżniał jeszcze shares, od stock i equity". Gdy niedawno opowiedziałem to, jako anegdotę, Rozłuckiemu, przyznał, że do dzisiaj nie czuje różnicy pomiędzy tymi pojęciami. A Andrzej Sopoćko, na miejscu, tj. na UCI, mógł skonfrontować swoją wiedzę z ekspertami w tej dziedzinie, co z pewnością korzystnie wpłynęło na kolejne poprawione i uzupełnione wydania książki pt. Giełda papierów wartościowych.

Na GSM UCI profesorem w dziedzinie strategii biznesowej był wówczas Peter Navarro. W dniu dzisiejszym jest to wpływowy doradca ekonomiczny Prezydenta USA Donalda Trumpa. To on wraz ze znanym inwestorem giełdowym Wilburem Rossem (dzisiejszym Ministrem ds. Handlu w rządzie Trumpa) byli głównymi autorami planu ekonomicznego Trumpa, który dobrze przez niego sprzedany wyborcom, przyczynił się do jego wyborczego zwycięstwa w 2016 roku.

Nie mniej interesująca była wizyta Andrzeja Sopoćko na Wydziale Ekonomii na UCLA. Byliśmy tam gośćmi u profesora George'a Murphy'ego. Pamiętał on ze swojego pobytu w Stanford University w latach 60. spacery z profesorem Oscarem Lange, a z czasów studiów na UCLA późniejszego noblistę w ekonomii Williama Sharpe'a - twórcę modelu wyceny aktywów kapitałowych (Capital Assets Pricing Model - CAPM). Po uzyskaniu doktoratu na UCLA Sharpe pierwszą pracę wykładowcy dostał na UCI. Profesor Murphy opowiadał nam o tych wspomnieniach, ale również o swojej ostatniej wizycie w Polsce, gdzie był kilka miesięcy wcześniej, towarzysząc Prezydentowi George'owi Bushowi. Profesor ilustrował swoje wspomnienia różnymi naukowymi opracowaniami, które prezentował ekonomistom i urzędnikom rządowym w Polsce, a to o rynku mieszkaniowym, a to o instrumentach dłużnych, które mogłyby wspierać rozwój Polski.

Opracowania te były zlokalizowane na podłodze gabinetu w stertach papierów o wysokości około dwudziestu centymetrów. Gdy weszliśmy do gabinetu profesora, do jego biurka i dwóch krzeseł prowadziła na 
podłodze równo wytyczona ścieżka wśród tych stert. Profesor w tej masie papierów bezbłędnie identyfikował odpowiednie opracowanie naukowe, o którym mówił. Gdy zauważył nasze zakłopotanie, gdy obserwowaliśmy jego poszukiwanie odpowiedniego dokumentu w stertach leżących na podłodze, ale i na biurku papierów, tak to skomentował: „Pewnie się dziwicie, widząc ten pozorny bałagan i pewnie myślicie, że mam taki bałagan w głowie, ale co byście pomyśleli o stanie mojego umysłu, gdyby tu nie było żadnej kartki papieru, że w jego głowie też nie ma żadnej myśli i wiedzy?". Oczywiście tak nie myśleliśmy, ale to spostrzeżenie było bardzo dla nas pouczające.

O UCLA warto powiedzieć jeszcze kilka słów. Sama uczelnia, obok UC Berkeley, jest czołową uczelnią publiczną na świecie. Od lat klasyfikowana jest na liście szanghajskiej na pozycji od dziesiątej do piętnastej. UCLA było jednym z pierwszych - spośród czterech węzłów protoplasty internetu - sieci dla celów militarnych APANET. To z komputera na UCLA wysłano pierwszy e-mail. To na UCLA studiował jeden z najważniejszych współtwórców internetu Paul Baran amerykański informatyk polskiego pochodzenia (urodzony w 1926 roku w Grodnie w rodzinie żydowskiej), twórca idei komutacji pakietów, która jest podstawowym mechanizmem działania m.in. internetu.

Niemniej interesujące były spotkania Andrzeja Sopoćko z moimi ówczesnymi pracodawcami, polskimi naukowcami z wcześniejszym doświadczeniem w Narodowym Centrum Badań Jądrowych w Świerku. Polscy fizycy, Andrzej Dąbrowski i Jan Iwańczyk, gdy trafili do USA z głowami pełnymi innowacyjnych pomysłów, postanowili utworzyć własny biznes pod nazwą Xsirius, Inc. - nazwa pochodzi od Syriusza - najjaśniejszej gwiazdy na nieboskłonie. Pierwszy i najważniejszym klientem było NASA - Amerykańska Agencja Badań Kosmicznych. Wkrótce okazało się, że rozwijane w Xsirius technologie mogą być kluczowe dla najważniejszego projektu militarnego prezydenta Ronalda Reagana Strategic Defense Initiative (SDI, popularnie zwanego wojnami gwiezdnymi, czyli Star Wars), czyli protoplasty dzisiejszej tarczy antyrakietowej, 
której elementy mają również znaleźć się na terenie Polski w Redzikowie na Pomorzu. Pierwszą i najważniejszą rozwijaną technologią była krzemowa fotodioda lawinowa dużej powierzchni (Large Area Avalanche Photodiode - LAPD). Pozwalała na detekcję najmniejszej jednostki energii, czyli „widzieć” w ciemności. Druga technologia to egzotyczny półprzewodnik jodek rtęci o unikalnych właściwościach. Instrumenty do analizy elementarnej zbudowane $\mathrm{z}$ wykorzystaniem tego galaretowatego kryształu $\mathrm{HgI}_{2}$ poleciały w misjach kosmicznych na Marsa. Trzecia technologia to nadprzewodnictwo wysokich temperatur - naukowcy Xsirius opracowali pierwszy prymitywny układ scalony w tej technologii.

Zapewne znaczenie tego projektu i technologii rozwijanych w Xsirius spowodowało, że do zarządu i rady nadzorczej tej w sumie małej firmy trafiły osoby o wysokim statusie w polityce amerykańskiej. Prezesem i przewodniczącym rady nadzorczej został dr William Graham - wcześniej Doradca ds. Naukowych Prezydentów Reagana i Busha. W radzie nadzorczej byli Richard Allen - wcześniej Doradca ds. Bezpieczeństwa Prezydenta Reagana (poprzednikiem był Zbigniew Brzeziński, w czasach Prezydenta Cartera) oraz Generał John A. Wickham Jr. - w latach 80. Szef Sztabu Generalnego Armii USA.

Xsirius nie tylko był czołowym w ówczesnej Ameryce inkubatorem supernowoczesnych i przełomowych technologii, ale również był niezwykle innowacyjny w dziedzinie finansowania i szybkiej komercjalizacji tych rozwiniętych już wewnętrznie technologii. Współpracując z najlepszymi firmami venture capital i patentowymi prawnikami, Xsirius wprowadził na giełdę trzy spółki. Było to dzieło polskiej kreatywności i przedsiębiorczości. W sumie na kluczowych pozycjach pracowało tam siedmiu Polaków. Główny pomysłodawca i kreator przedsięwzięcia, dr Andrzej Dąbrowski wzbogacił się na tyle, że stał się właścicielem okazałej posiadłości w Beverly Hills. Profesorowie Andrzej Sopoćko i Andrzej K. Koźmiński, a przy innej okazji Dariusz Rosati byli gośćmi w tym prestiżowym miejscu. 
Zarządzanie i organizacja innowacyjnych prac badawczo-rozwojowych przez rozproszone zespoły naukowców i inżynierów, finasowanie tych prac przez venture capital z jednej strony, a przez rządowe granty z drugiej, wreszcie umiejętność zarabiania na tych innowacjach i szybka komercjalizacja rozwiniętych już technologii, to wiedza, która jest istotą budowania innowacyjności i konkurencyjności gospodarki polskiej w ramach Strategii Odpowiedzialnego Rozwoju Premiera Mateusza Morawieckiego, a wiedzę taką zdobył bezpośrednio już wówczas Andrzej Sopoćko, wizytując Xsirius, Inc.

W wyniku prac naukowców w Xsirius i powiązanych z nią spółek, których rezultaty oryginalnie miały mieć zastosowania militarne lub kosmiczne, później powstały technologie i innowacyjne produkty o cywilnym przeznaczeniu. Wśród najważniejszych był niewielki, a więc i dużo tańszy skaner komputerowy dla neurochirurgii mózgu czy superczuły i wydajny detektor do skanerów w bramkach w portach lotniczych.

$\mathrm{Na}$ koniec może jeszcze kilka słów, jak zostałem pierwszym asystentem Andrzeja Sopoćko na Wydziale Zarządzania UW i potencjalnie pierwszym jego doktorantem, oraz jak i dlaczego Andrzej Sopoćko trafił później do Południowej Kalifornii. W połowie roku 1982 (początek stanu wojennego) obroniłem pracę magisterską w zakresie zastosowania metod matematycznych $\mathrm{w}$ zarządzaniu złożonymi przedsięwzięciami. Wtedy pojawił się nowy Zakład Cybernetyki Organizacji. Nazwa ta bardzo mnie zafrapowała i zainspirowała do spotkania z jej szefem. Przedstawiłem kilka swoich pomysłów o możliwości i potrzebie utworzenia para-giełdy w gospodarce centralnie planowanej, która by pomagała lepiej organizować i równoważyć funkcjonowanie tej gospodarki. Inny pomysł dotyczył rozwoju i wzrostu najbardziej efektywnych przedsiębiorstw, które $\mathrm{w}$ ten sposób zasługiwałyby na przejmowanie innych podmiotów o słabszych wynikach ekonomicznych. Tego typu myślenie nie było zbyt powszechne, zapewne m.in. dlatego dostałem propozycję, abym został asystentem. 
Gdy zaczęła się nasza współpraca, niektórzy inni młodzi pracownicy naukowi trochę mnie żałowali, sądząc, że nie jest ona taka łatwa. Po jednym z długich i erudycyjnych wystąpień Andrzeja Sopoćko na forum kadry naukowej wydziału, jeden z kolegów zadał mi pytanie, jak udaje mi się porozumiewać z szefem, bo on, słuchając go, szybko się gubi i przestaje rozumieć wywód. Trochę zaskoczony tym pytaniem, zażartowałem, że słucham pierwszych zdań, gdzie postawiona jest teza wywodu, później nie jestem zbyt skupiony na słuchaniu, aby się zbytnio nie męczyć, ale uważam, czy szef już nie kończy wywodu, czyli go nie podsumowuje. Jednym słowem wystarczy słuchać tylko początek i koniec, a wtedy wszystko jest klarowne i zrozumiałe. Po kilku miesiącach ten sam kolega przyznał mi się, że korzysta z mojej rady i od tej pory wywody Andrzeja Sopoćko stały się dla niego rzeczywiście jasne.

Andrzeja Sopoćko zawsze intrygowały tematy trudne i złożone w teorï ekonomï, organizacji, finansach. Moje dość naiwne pomysły wpisywały się do pewnego stopnia w jego ówczesne zainteresowania naukowe. $\mathrm{Na}$ początku lat 80 . zajął się teoretycznym opisem i próbą wyjaśnienia podstawowego problemu gospodarki polskiej - systemowym brakiem równowagi. Wynikiem tych przemyśleń była wydana w 1983 roku książka Równowaga - powiąania poziome - struktura gospodar$c z a$. Pod wpływem tej pracy oraz moich studiów teorii Janosa Kornaia gospodarki niedoborów, wpadłem na następujący pomysł. Brak własności prywatnej powoduje, że gospodarka socjalistyczna musi być organizowana za pomocą systemu planowania. A realna gospodarka według Kornaia wszędzie jest w nierównowadze, a kolejki są powszechne. Dlatego plany powinny z założenia być niezrównoważone, a w ten sposób bardziej realistyczne. Andrzejowi Sopoćko pomysł się podobał, ale na temat pracy doktorskiej sugerował wybrać coś niekontrowersyjnego.

W roku 1985 zainicjowałem utworzenie (przez studentów) na Wydziale Zarządzania UW organizacji AIESEC, tak jak funkcjonowało to np. na SGPiS. Udało mi się dostać praktykę AIESEC na peryferiach Los Angeles. Gdy już miałem wracać, rok później 
w sierpniu, udałem się na UCLA, aby się zorientować, czy mógłbym kiedyś w przyszłości tam studiować. Zostałem skierowany do Profesora George'a Murphy'ego, który zajmował się gospodarką socjalistyczną. Opowiedziałem mu o swoim pomyśle niezrównoważonego planowania. Pomysł mu się spodobał na tyle, że zaproponował przyjęcie mnie na studia bez żadnych egzaminów, listów rekomendacyjnych czy pieniędzy. Trudno było odmówić. Tak zostałem w Kalifornii. A kilka lat później zaprosiłem do siebie Andrzeja Sopoćko.

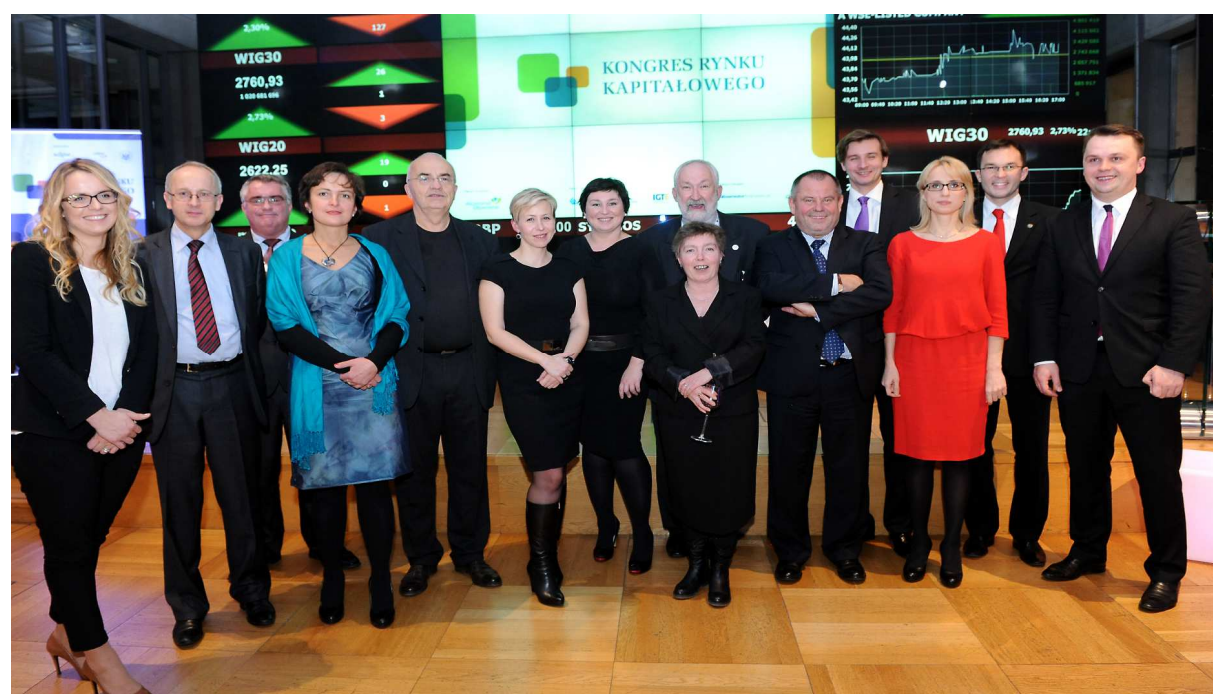

Profesor Andrzej Sopoćko po latach w Sali Notowań Giełdy Papierów Wartościowych w Warszawie. Gala finału Konkursu Kongresu Rynku Kapitałowego, listopad 2013.

Fot. Jerzy Krupowies. 


\section{Stanisław Nowak}

Krystyna Rychlica

\section{Izba Gospodarcza Ubezpieczeń i Obstugi Ryzyka o Profesorze Andrzeju Sopoćko}

Szczerze przyznajemy, że informację Pani dr hab. Renaty Karkowskiej, o zamierzonym, a specjalnym wydaniu okazjonalnym dla Profesora Andrzeja Sopoćko, przyjęliśmy z dużą niewiarą typu „O już?”. Dopiero po przypomnieniu sobie rzymskiej maksymy tempus fugit, przede wszystkim wobec własnej osoby, z pokorą przyjęliśmy jej oddziaływanie także wobec Andrzeja.

Znając niechętny stosunek do wszelakich uroczystości chwalebnych, ewentualną formę „laurki” pod jego adresem, uznaliśmy za oczywistą niestosowność, ale po naradzie w gronie kolegów z Izby Gospodarczej Ubezpieczeń i Obsługi Ryzyka, w której Profesor Andrzej Sopoćko działa nieprzerwanie od kilkunastu lat, uznaliśmy, że warto będzie przypomnieć tę jego działalność i zasługi dokonywane na rzecz wiedzy o ryzyku i kształtowaniu polskiego rynku finansowo-ubezpieczeniowego, także w ramach prac Profesora jako działacza tejże Izby. 
O ile znamy Jego skromność, przypomnienie to uświadomi Jemu samemu i innym adresatom naszej wypowiedzi, znaczący dorobek zarówno Profesora, jak i Izby, i da Mu poczucie dobrze spełnionego obowiązku.

\section{Stowo o Izbie}

Przyjęta, na konferencji naukowo-praktycznej pt.: Problemy $i$ kierunki rozwoju rynku ubezpieczeniowego $w$ Polsce, odbytej dnia 22 marca 2002 r., w gościnnych progach ówczesnej Wyższej Szkoły Przedsiębiorczości i Zarządzania im. Leona Koźmińskiego (obecnie Akademia im. Leona Koźmińskiego), Uchwała Programowa Izby Gospodarczej Ubezpieczeń i Obsługi Ryzyka, pokazała konieczność powołania organizacji wspierającej rozwój tegoż rynku.

Przywoływana uchwała programowa, współgrająca z wnioskami z dyskusji konferencyjnej wskazywała ówczesne problemy, z którymi przyszło borykać się tworzącemu się rynkowi ubezpieczeń'. Przyjęliśmy stanowisko, że: „Podstawowym zadaniem Izby jest działanie na rzecz integracji środowiska wszystkich uczestników rynku ubezpieczeń, dla rozwoju tegoż rynku oraz gospodarki narodowej [...]. Rozwój tego rynku, odpowiednio szybki dla zadośćuczynienia naszym aspiracjom, nie będzie możliwy bez wydatnego przyrostu wiedzy o ryzyku, we wszystkich jego przejawach i dostępnych formach obchodzenia się z nim. Izba wspierać

\footnotetext{
1 Wymienia się tu m.in. niebezpieczeństwo zdominowania polskiego rynku przez kapitał zagraniczny, wadliwej legislacji prawa ubezpieczeniowego oraz potrzeby zmian kodeksu cywilnego w sprawach umowy ubezpieczenia, konieczność wsparcia przez państwo rozwoju sektora ubezpieczeń wzajemnych czy zatrzymania trendów pogorszenia praw ubezpieczonych w stosunkach prawnych umów ubezpieczenia i uporządkowania systemu ubezpieczeń obowiązkowych. Już wtedy zwracano uwagę na postępujący proces dekomunizacji ubezpieczeń.
} 
będzie edukację całego społeczeństwa $\mathrm{w}$ tym zakresie oraz popierać kształcenie profesjonalistów."

Apel spotkał się z życzliwym zainteresowaniem władz ówczesnego Ministerstwa Finansów, w którym Profesor Sopoćko pełnił funkcję Podsekretarza Stanu, odpowiedzialnego za sektor bankowości i ubezpieczeń. Odpowiadając na potrzeby rynku ubezpieczeń, Profesor Andrzej Sopoćko na kolejnej konferencji naukowej, odbytej 25 kwietnia 2003 r. $\mathrm{w}$ wystąpieniu wprowadzającym wskazał na najważniejsze problemy polskich ubezpieczeń, wymieniając wśród nich: europejskie ich korzenie, konieczność kontynuacji przebudowy polskiego prawa ubezpieczeniowego problem organizacji rynku ubezpieczeń, system polskiego pośrednictwa ubezpieczeniowego oraz edukacji ubezpieczeniowej.

Uznanie w statusie Izby, zadań edukacji ubezpieczeniowej za jeden z najważniejszych kierunków działań oraz szeroki oddźwięk problematyki pierwszych konferencji naukowych stały się przesłanką dla władz Izby do kontynuacji tej formy edukacji ubezpieczeniowej jako corocznego zadania podejmowanego przez Izbę, wspólnie z grupą czołowych szkół akademickich w kraju oraz podmiotów regionalnych, czy branżowych.

Jednym ze szczególnych przykładów organizacyjno-merytorycznego zainteresowania Andrzeja jest problematyka regionu świętokrzyskiego, jego bogata historia społeczna i przemysłowa, oraz niewykorzystane piękno Ziemi Świętokrzyskiej. Należy podkreślić Jego aktywny udział w kilku konferencjach naukowych, współorganizowanych przez Izbę, Wydział Zarządzania Uniwersytetu Warszawskiego oraz Uniwersytet Jana Kochanowskiego w Kielcach. Były one poświęcone problemom tej Ziemi, tradycji, ale także jej przyszłości w ramach programów UE. Namacalnym dorobkiem tych konferencji było wydane w 2012 roku zbiorowe opracowanie: Regionalny program rozwoju ${ }^{2}$, którego Profesor Sopoćko jest współredaktorem naukowym.

2 Regionalny program rozwoju na tle strategii UE „Europa 2020”, z uwzględnieniem roli ubezpieczeń - na przykładzie Województwa Świętokrzyskiego, Wyd. IGUiOR, Warszawa 2012. 
Z zainteresowania rozwojem regionów wyrosła idea cyklu wydawniczego poświęconego problematyce Ziemi Świętokrzyskiej pt.: Almanach Świętokrzyski, w którym Profesor Andrzej Sopoćko występuje zarówno jako członek Rady Programowej cyklu, autor, czy redaktor naukowy.

Kolejne dowody Jego zainteresowania tematyką branżową (przemysł górnictwa i hutnictwa czy rolnictwa) stanowi wydanie zbiorowe Izby o tytule: Przemyst wydobywczo-przetwórczy węgla i rudy żelaza a rozwój gospodarczy (elementy historii, rola ubezpieczeń, potrzeby $i$ kierunki rozwoju), w którym Andrzej zajmuje się złożoną problematyką instrumentów pochodnych w górnictwie. We współpracy z Izbą w publikacji: Ubezpieczenia na rzecz gospodarki globalnej, sektorów i regionów umieścił artykuł: Nowe rynkowe instrumenty reasekuracji.

Andrzej, po uwolnieniu się z gorsetu pracownika centralnej administracji państwowej, już jako wykładowca akademicki, szczególnie od czasów objęcia profesury na Wydziale Zarządzania UW, podejmuje współpracę z Izbą, także jako jeden z wiceprzewodniczących zarządu Izby.

Z bogatej tradycji kilkudziesięciu różnorakich zgromadzeń naukowo-praktycznych Izby, a w tym 20 konferencji naukowych, co najmniej kilkanaście z tych ostatnich, odbyło się dzięki inspiracji, współorganizacji, moderowaniu, wykładom, czy dyskusji z Jego udziałem.

Współpraca Izby ze środowiskami wielu uczelni krajowych i zagranicznych ośrodków naukowo-akademickich doprowadziła do wydania kilkudziesięciu pozycji wydawniczych, znów z wielokrotnym, aktywnym ich wspóttworzeniem przez Profesora Sopoćko.

Dla Izby szczególnie cenne w tym obszarze są pozycje wydawnicze powstałe $\mathrm{w}$ trakcie wieloletniej jej współpracy z Wydziałem Zarządzania Uniwersytetu Warszawskiego, szczególnie, w warunkach patronatu wydawniczego prof. Alojzego Z. Nowaka - dziekana Wydziału. Skalę owej współpracy można uznać za znaczącą, jeśli weźmie się pod uwagę 
choćby liczbę współorganizowanych konferencji naukowych oraz innych przedsięwzięć.

W przekazanym do rąk czytelników, w połowie 2018 roku, zbiorowym wydaniu książkowym o tytule: Polski obszar europejskich rynków finansowo-ubezpieczeniowych $A D$ 201733, w którym Profesor A. Sopoćko zamieścił artykuł pt.: Gtówne czynniki ryzyka systemowego $w$ Polsce, autorzy Wprowadzenia otwierającego opracowanie zbiorowe, przywołują w Bibliografii do tegoż wprowadzenia blisko 30 artykułów i pozycji zwartych, które na przestrzeni ostatnich 10 lat współpracy Izby z Uniwersytetem Warszawskim (głównie Wydziałem Zarządzania) ukazały się jako pokłosie wspólnych przedsięwzięć poświęconych najważniejszym problemom rynków finansowo-ubezpieczeniowym Polski, jako członka UE. W większości przywoływanej literatury pojawia się nazwisko Andrzeja Sopoćko, łączącego pasję profesora akademickiego z potrzebą społecznego spełnienia się, także w działaniach Izby.

W miejsce podsumowania pragniemy w imieniu kolegów z Izby i własnym, zwrócić uwagę na fakt, że Profesor Andrzej Sopoćko jest od kilku już lat laureatem nagrody honorowej Izby Gospodarczej Ubezpieczeń i Obsługi Ryzyka - w kategorii Lider Edukacji Ubezpieczeniowej oraz, że wielokrotnie był powoływany w skład kapituły honorowej owej nagrody, także jako jej przewodniczący.

Jako PS zamieszczamy odbitkę zdjęcia, na którym Profesor Andrzej Sopoćko pełni honory gospodarza, przyjmującego delegację rynku ubezpieczeniowego USA oraz uczestniczy w uroczystości rozdania nagród na Uniwersytecie J. Kochanowskiego w Kielcach.

3 Polski obszar europejskich rynków finansowo-ubezpieczeniowych AD 2017, red. A.Z. Nowak, S. Nowak, J. Jagodziński, Wyd. Naukowe UW WZ (we współpracy z IGUiOR), Warszawa 2017. 


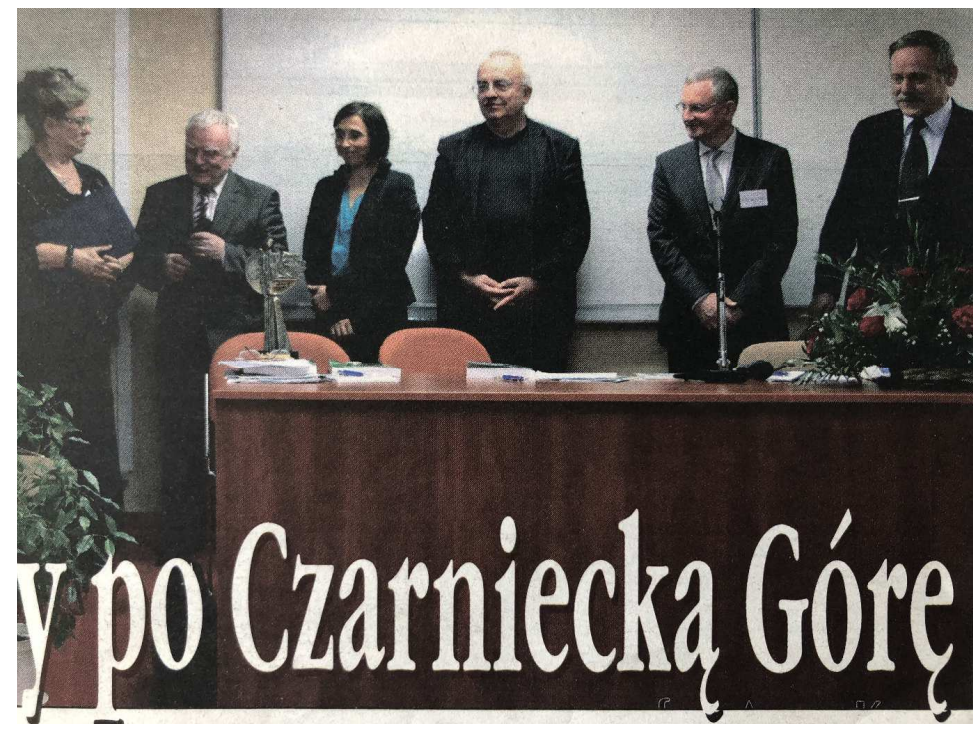

Rozdanie nagród IGUiOR podczas konferencji na Uniwersytecie

J. Kochanowskiego w Kielcach, 25 kwietnia 2012

Fot. Gazeta Ubezpieczeniowa nr 19(682). Materiat archiwalny IGUiOR

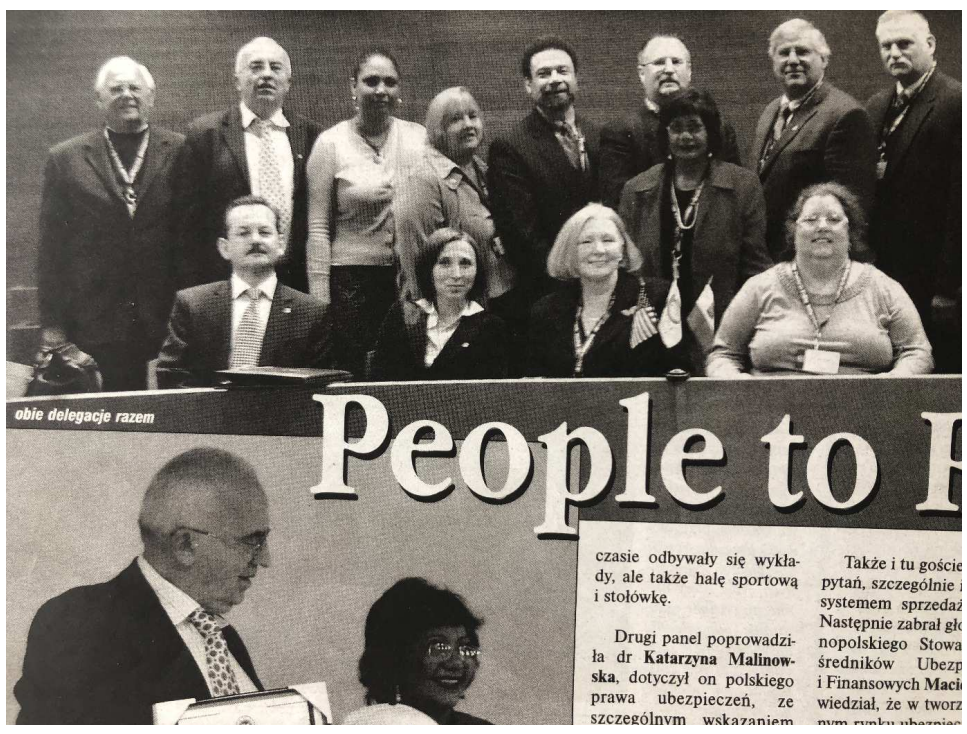

Delegacja amerykańskich specjalistów w dziedzinie zarządzania ryzykiem i ubezpieczeniami w Polsce

Fot. „Gazeta Ubezpieczeniowa”, nr 49(504). Materiat archiwalny IGUiOR 



\section{Pokolenia wychowane przez Profesora Andrzeja Sopoćko}





\section{Renata Karkowska \\ Paweł Karkowski}

\section{Inteligencja i sentymentalizm}

$\mathrm{J}$

eżeli ktokolwiek uważa, że sukces polskiego rynku kapitałowego odbył się bez udziału Profesora Sopoćko, to trwa w blędzie poznawczym w jego odmianie zwanej heurystyką zakotwiczenia. Po pierwsze, sukces ten już się zdarzył i nie zanosi się na powtórkę, po drugie trudno nam poznać jego praprzyczynę, a jeszcze trudniej zdiagnozować przyczynę jego stabilnej geriatryzacji i podać dokładną datę jego upadku. Trudno postawić diagnozę, ponieważ może się znaleźć kolejny taki idealista, który naukowo będzie udowadniał, że rynek kapitałowy ma w Polsce szanse funkcjonować i który potraktuje chciwość nie jako zdobycz cywilizacyjną ponowoczesnej ekonomii, ale jako infantylną przyczynę działania, a w uczestników rynku kapitałowego tchnie ożywczy wstyd. Wtedy nastąpi inwentaryzacja portfeli i ze zdumieniem wyrzuci się z niego po niskiej (ale bez przesady) cenie na rynek zdywersyfikowane aktywa zdobyte przeciwko siódmemu przykazaniu. A więc rynek wydawniczy należy śledzić z uwagą, bo książa może mieć mylący tytuł np.: Pochodne, droga do fortuny. Oby tak było; na razie główny idealista rynku kapitałowego, 
bohater niniejszych wspomnień, nie pisze o nim; mam nadzieję, że zbiera siły. A pisze bardzo przystępnym i obrazowym językiem, który poznałem już podczas wykładów Andrzeja. Ogólnie materia rynku kapitałowego jest nudna, zawiera np. pochodne, które kojarzą się laikom z rachunkiem różniczkowym Leibniza bądź Newtona, a oni na muzealnych obrazach mają bardzo smutne twarze. Mając tego świadomość, Andrzej opierał się na edukowaniu przez przykłady wzięte z życia i istotę kontraktu „forward" tłumaczył mniej więcej tak:

Mojsze z Ickiem idą przez łąkę i spotykają żabę.

- Icek, a zjadłbyś żabę?

- Coś Ty!

- A za 1000 dolarów?

- A za 1000 dolarów to bym zjadł.

I Icek zjadł żabę. Idą dalej i spotykają kolejną żabę i tym razem Icek pyta Mojsze:

- A Ty za 1000 dolarów zjadłbyś żabę?

- Zjadłbym!

I Mojsze zjada żabę. Potem idą dalej i Icek pyta Mojsze:

- Słuchaj, ja zjadłem żabę i Ty mi dałeś 1000 dolarów, potem Ty zjadłeś żabę i ja ci dałem 1000 dolarów, czy to miało sens?

- Może i nie miało, ale żeśmy pohandlowali!

$\mathrm{Na}$ taką konkluzję padło pytanie z sali, jak można zarobić na pochodnych, skoro są one grą o sumie zerowej? I tu Andrzej stwierdził, że trzeba ze zwykłego inwestora stać się filozofem, wtedy da się zarobić również na pochodnych, a różnicę zilustrował następującym dowcipem o główkach śledziowych:

W przedziale kolejowym jadą kupiec i szlachcic, i ten pyta:

- Panie Kupiec, niechże Pan mi powie, skąd wy kupcy macie taką dobrą głowę do interesów? 
Kupiec, który właśnie jadł śledzia, uśmiecha się i mówi:

- Widzi Pan, Panie Dziedzicu, my Kupcy jadamy bardzo dużo ryb, i to razem z głowami. W ciele ryby, a zwłaszcza w jej głowie, znajduje się dużo fosforu. Fosfor rozwija komórki mózgowe i sprawia, że jesteśmy tak dobrzy w interesach.

- Panie Kupiec, odsprzedaj mi kilka śledzi.

Kupiec odmawia. Szlachcic proponuje mu po pięć rubli za sztukę, potem dziesięć, potem piętnaście, a nawet dwadzieścia... Wreszcie, po długich targach, Kupiec zgadza się sprzedać mu dwa śledzie za pięćdziesiąt rubli. Szlachcic zjada je z apetytem, ale niebawem odczuwa pragnienie. Na najbliższej stacji wychodzi więc z pociągu i idzie do bufetu, aby napić się piwa. Po chwili wraca do przedziału i mówi do Kupca:

- Ale ze mnie głupiec, że zapłaciłem Panu tyle pieniędzy za te śledzie. Przecież mogłem poczekać do tej stacji i kupić je tutaj za trzydzieści kopiejek.

- O widzi Pan, Panie Dziedzicu! - woła Kupiec. - To już działa!

Ze studiów zapamiętałem, że Profesor nigdy nie lubił źle przygotowanych studentów, szczególnie płci pięknej. Uważał, że wdzięk i wiedza dadzą się pogodzić i tego wymagał. Wymagające i skrupulatne było przeprowadzanie egzaminów: podział na grupy, nowy podział przestrzenny ławek i uważny monitoring ściągających, dla których nie było pobłażania. $Z$ tego, co pamiętam, oprócz części pisemnej, była też część ustna.

W międzyczasie, zachęcony do rynku kapitałowego z innymi studentami zdałem egzamin maklerski i rozpocząłem weryfikację wiedzę przekazanej przez Profesora. I w 1999 r. wielkie zaskoczenie: wszechobecne procedury, system informatyczny GPW, zmowy, insiders trading itd. A gdzie ludzie? Gdzie giełda, o której mówił Profesor, gdzie zaufanie i powszechny dobrobyt mający mieć źródło w rynku kapitałowym? 
Wszyscy chyba zrozumieliśmy po plajcie programu $500+$ (spieszę wyjaśnić, że chodzi o powszechne świadectwa udziałowe, fundusze NFI i 512 prywatyzowanych spólek), że rynek kapitałowy w kształcie przedstawionym przez Profesora, choć mógłby nadal trwać, nadaje się bardziej dla antropologów antycznych niz dla nowoczesnych inwestorów. W zasadzie każdy, kto naprawdę dbał o domowy budżet, odchodził z giełdy, a czas potwierdził słuszność tej decyzji. Mógł ze spokojem obserwować, jak rekiny z braku mniejszego narybku rozpoczynają wzajemny kanibalizm.

Czy znajdzie się jeszcze jeden taki Profesor, który przywróci studentom wiarę w idee rynku kapitałowego? W dystrybucję kapitału z pominięciem banku od prywatnego inwestora, który chce odłożyć na lepszą emeryturę do uczciwej, organicznie rozwijającej się spółki, niekoniecznie handlującej elektrycznymi dronami i samochodami w PowerPoincie?

Andrzej został promotorem mojej pracy doktorskiej, a także promotorem pracy doktorskiej pewnej Renaty, która pracowała z nim w banku PBK. Jego plan poznania i zeswatania nas udał Mu się doskonale; za rok byliśmy małżeństwem, za co jesteśmy wdzięczni (z wyjątkiem krótkich chwil spędzonych na rodzinnych sprzeczkach).

Które cechy Andrzeja są najbardziej wyróżniające? Stwierdziłbym, że są to: idealizm, inteligencja, sentymentalizm i stałość poglądów.

\section{* * *}

Tako żona autora dotychczasowej wypowiedzi chciałabym się od niej odciąć grubą kreską :) (zgadzam się tylko co do wdzięczności za poznanie Pawła i z tym, że tak zabawnie i stosownie do zaistniałej sytuacji opowiadają dowcipy jedynie Profesor Andrzej Sopoćko i mój mąż. Ten drugi zapewne dlatego, że pilnie uczęszczał na wykłady Profesora).

Moja opowieść z Profesorem Sopoćko (od wielu już lat Andrzejem) w roli głównej zaczęła się w departamencie skarbu wspomnianego wcześniej banku. Chociaż nie współpracowaliśmy ze sobą, to zajmowaliśmy jeden pokój. Łączyła nas również jedna pogodna, ale zakręcona postać 
wiceprezesa banku. Andrzej był jego głównym ekonomistą, ja asystentką. Spotykaliśmy się głównie na zebraniach członków zarządu banku, na których nie tylko ja uczyłam się, jak funkcjonuje bank - dla naszego wiceprezesa, z pochodzenia Austriaka, realia młodego rynku kapitałowego w Polsce też były nowym wyzwaniem. Czasami zdawało mi się, że polska rzeczywistość go przerastała. Pewnego dnia przyszedł do pracy bardzo podirytowany faktem, że skradziono mu radio z jego bankowej limuzyny, którą, nie zamknąwszy, zaparkował w centrum Warszawy. Trzeba było wtedy widzieć zdziwienie w oczach tego starszego Pana, dlaczego warszawska policja nie ruszyła natychmiast w pogoń za złodziejem...

Zafascynowana pracą w bankowości szybko nabrałam przekonania, że nie jest to mój cel życiowy. Zbiegło się to z propozycją Andrzeja dotyczącą studiów doktoranckich na Wydziale Zarządzania. Nie zastanawiałam się długo, bo zawsze drzemała we mnie dusza naukowca. Pod opieką Andrzeja napisałam pracę doktorską, dotyczącą rozwoju rynku kredytowych instrumentów pochodnych w Polsce. W sumie postawiona teza o istotnych barierach rozwoju tego rynku w Polsce nadal jest aktualna, mimo że minęło już ponad 10 lat. Pod czujnym okiem Profesora powstawały wówczas dwie prace doktorskie. Na szczęście nie takie same! Drugą, o zasadności przejęcia zarządzania ryzykiem przedsiębiorstw przez bank, pisał mój mąż. Obroniliśmy się w jednym roku akademickim 2005/2006: 14 listopada 2005 była moja obrona, natomiast Pawła już 11 stycznia 2006. Na recenzentów naszych doktoratów Andrzej wybrał tych samych profesorów: profesora Leszka Dziawgo z Uniwersytetu Mikołaja Kopernika w Toruniu, oraz profesora Mariana Górskiego z Wydziału Zarządzania UW. Celem takiego rozwiązania było również wykluczenie podejrzeń o podobieństwo treści i rzekome pisanie doktoratów przez jednego z małżonków. Trudno powiedzieć, kto wtedy miał więcej czasu na napisanie dwóch doktoratów? Ja czy Paweł? Obydwoje pracowaliśmy w bankach, a nasza córeczka Alusia stawiała pierwsze kroki. Był to okres bardzo intensywnej pracy, ale i nie pozbawiony przyjemności, w końcu dzięki wsparciu naukowemu Andrzeja obroniliśmy 
doktoraty, a jego plan matrymonialny nadal się realizował... za rok urodziła się nasza druga córka Małgosia.

Jako młoda pani doktor trafiłam do Zakładu Ubezpieczeń i Rynków Kapitałowych na Wydziale Zarządzania i od tego czasu Andrzej został oficjalnie moim szefem. Może zabrzmiało to poważnie, ale w rzeczywistości był to okres miłych wspomnién. Profesor ma proste zasady: określania grubych celów, traktowania swoich współpracowników po partnersku i obdarzania ich zaufaniem. To ostatnie chyba najbardziej budowało nasz zakład i pozwalało bez cienia wątpliwości kontynuować współpracę przez tak długi okres. Najwyraźniej jest to cecha istotna nie tylko dla efektywnie funkcjonującego rynku kapitałowego, jak często powtarzał Profesor swoim studentom, ale i relacji międzyludzkich. Jej brak powoduje destrukcję i niechęć. Ale nie rola Andrzeja jako szefa jest tu najważniejsza. Raczej wrodzona troska o drugiego człowieka i empatia, jaką przejawiał na co dzień powodowały, że często traktowałam go jako ojca (przynajmniej chrzestnego). Po latach współpracy wydaje się, że zawsze między nami pozostawały „drzwi” - otwarte, jeśli tylko po jednej stronie rozległo się pukanie i zamknięte w czasie wolnym od problemów akademickich. Wydaje się, że wzajemny szacunek, bez uporczywego pukania i wyważania tych drzwi przez jedną ze stron, był istotną cechą wzajemnych relacji między nami.

$\mathrm{Na}$ co dzień Andrzej zwykle nie przyodziewa maski, więc śmieje się z rzeczy śmiesznych i roni łzy nad ludzkim nieszczęściem. Taki naturalny sposób bycia powoduje, że gromadzi wokół siebie ludzi w różnym wieku, niezależnie od posiadanych tytułów akademickich. W tym, co robi i czym się interesuje rzadko ulega modom, dlatego nie ocenia rzeczy pochopnie, a z naukowym zacięciem poszukuje prawdy. Nie liczą się dla niego wysokie wskaźniki punktacji publikacyjnych, czy licznie odbyte konferencje, ale rzetelność i merytoryczna wartość pisanego tekstu naukowego. Dla mnie pozostanie zawsze sentymentalnym idealistą.

Andrzeju, żyj nam jak najdłużej, zdrowie niech $\mathrm{Ci}$ dopisuje, szczęście nie omija, każda muza obfitością służy! 


\section{Andrzej Kurnicki}

\section{Café and capital - rozmowy przy kawie}

V iałem przyjemność spotykania się z Panem Profesorem wiele razy, 1978-1984, ale także jako wykładowca akademicki prowadzący wykłady dla studentów zagranicznych w programie IBP na wydziale. Już w latach późniejszych, jako doktorant WZ UW, uczestniczyłem w wielu konferencjach organizowanych przez środowiska akademickie, naukowe, biznesowe czy stowarzyszenia związane z polskim rynkiem kapitałowym, którego Pan Profesor był nie tylko jednym z pionierów, ale i aktywnym intelektualnie oraz organizacyjnie uczestnikiem, tworząc ramy instytucjonalne, prawne i społeczne polskiego systemu finansowego.

Przed przyjazdem do Polski, a była to moja pierwsza wizyta w kraju po wyjeździe w 1984 r., zadzwoniłem do Pana Profesora, proponując spotkanie w Warszawie. W czasie rozmowy krótko powiedziałem o tym, co robię w USA, jakie mam doświadczenie (właśnie w tym okresie zmieniłem pracę z firmy ubezpieczeniowej na bank inwestycyjny) i od razu padła ze strony Pana Profesora propozycja, abym na planowanym 
spotkaniu przedstawił zasady funkcjonowania rynku amerykańskiego, ale, jak zaproponował Profesor w kontekście udziału banków inwestycyjnych, jako głównych i instytucjonalnych filarów mechanizmu rynku pieniężnego oraz kapitałowego. Jak sięgnę pamięcią, to Pana Profesora szczególnie interesował mechanizm wyceny akcji przed IPO i, dodatkowo, jak wygląda procedura w ujęciu prawnym i technicznym tzw. market maker w okresie po debiucie firmy na giełdzie. Profesora interesowała także tematyka polityki stabilizacyjnej FED-u i rola Rezerwy Federalnej w stabilizacji systemu finansowego z wykorzystaniem rynku kapitałowego. Tak się złożyło, że byłem akurat po egzaminach na doradcę inwestycyjnego (serie 7, 63, wcześniej 6 i 22) oraz po zaliczaniu prawie 60 godzin wykładów i ćwiczeń z zakresu Corporate Finance prowadzonych na University of Maryland na Wydziale Prawa przez jednego z prawników (prof. Both), eksperta w kwestii prawa giełdowego i funkcjonowania rynku kapitałowego. Wykłady z polityki monetarnej z dr. Bobem McTeerem też wyjątkowo wzbogaciły moją wiedzę o praktyczne działania i zasady funkcjonowania Rezerwy Federalnej.

Miałem już za sobą kilkuletnie doświadczenie w pracy w sektorze finansowym i w miarę solidne przygotowanie akademickie na jednym z uniwersytetów w Baltimore. Temat zaproponowany przez Pana Profesora też wydał mi się dość ciekawy, szczególnie, że moje zainteresowanie skoncentrowane było na polityce monetarnej i rynkach kapitałowych. Polityka monetarna i reakcje rynku kapitałowego w kontekście oczekiwanych(lub nieoczekiwanych) zmian stóp procentowych w USA wywoływały zawsze sporo dyskusji - zarówno ze strony keynesistów, neokenesistów, nowej szkoły keynsowskiej, jak i wreszcie akademików z czołowych uniwersytetów amerykańskich broniących wolnego rynku odwołujących się do Rothbara czy Miltona Friedmana. Spory na poziomie akademickim były dość intensywne, w różnych okresach, ale linia podziału nie przebiegała jednak tak wyraźnie, jak można byłoby wyartykułować na podstawie dostępnych publikacji w książkach akademickich. Ekonomiści środowisk bankowo-inwestycyjnych podkreślali znaczenie przewidywanych zmian 
długoterminowych stóp procentowych(10 yield TBonds) jako wypadkowej zmian stóp krótkookresowych. Z kolei w samym FED-dzie istniała także (i nadal istnieje) zauważalna linia podziału między ekonomistami stanowiącymi zaplecze analityczne i doradcze poszczególnych prezesów wchodzących w skład Rezerwy Federalnej. Wypowiedzi samych prezesów banków centralnych z Rezerwy Federalnej dotyczące roli FED-u w okresie fazy załamania czy kryzysu finansowego, też niekiedy odbiegały od standardowego szablonu, przyjętego przez FED, „systemu komunikacji z rynkami".

Sześć tygodni przed wyjazdem do Polski postanowitem skoncentrować się na sprawach szczególnie interesujących Pana Profesora. Wiedza z wykładów wydawała mi się dość świeża, a amerykański system kształcenia przyszłych finansistów i bankierów inwestycyjnych według tzw. case'ów nie tylko zawsze sprzyjał poznaniu nowych pojęć, lecz także wyrabiał dobry praktyczny nawyk utrwalania nabytej wiedzy i podejmowania decyzji w sytuacji zbliżonej do realnych warunków mechanizmu rynkowego. Jeszcze raz przejrzałem swoje materiały dotyczące rynku giełdowego, oraz przestudiowałem podręcznik z zakresu prawa obowiązującego (SEC i NASD) na rynku podstawowym NSE, oraz rynku transakcji elektronicznych (NASDAQ).

$\mathrm{Na}$ wstępie spotkania opowiedziałem kilka słów na temat swojej przygody emigracyjnej i o swoich doświadczeniach jako broker w USA. Już po kilku minutach rozmowy dość sprawnie przeszliśmy do dyskusji na temat polskiego rynku kapitałowego, z wcześniejszym wprowadzeniem, Pana Profesora na temat tworzenia się pierwszych prawnych i instytucjonalnych podstaw obrotu instrumentami finansowymi. Zreferowałem krótko regulacje federalne dotyczące transakcji określanych jako tzw. discresionary transaction. Profesora szczególnie zainteresował tzw. inside rules, które, mówiąc w skrócie, polega na wewnętrznym regulaminie instytucji finansowej o zaostrzonym rygorze przestrzegania zasad etycz- 
nych i zawodowych w relacjach z klientami i instytucjami (raportowania) niż wymagają tego przepisy federalne czy stanowe.

Druga część spotkania odbyła się po południu w kawiarni hotelu Marriott, gdzie przy dobrej kawie i znakomitym cieście dołączył do nas pan prof. Jan C. i prezes znanej firmy nieruchomości, także absolwent WZ UW, ekspert w dziedzinie europejskiego rynku w tym zastosowania instrumentów finansowych na niemieckim rynku nieruchomości, znany warszawski deal shaker. Profesor najpierw przedstawił dyskutantów, tematy do omówienia oraz ustalił kolejność wypowiedzi, czas i formułę dyskusji. Mówiąc szczerze, byłem nieco zaskoczony tym formalnym przyjęciem formuły spotkania, ale, mając już doświadczenie amerykańskie, chętnie przystałem na zaproponowany porządek, przyjumując, że nie jest to spotkanie weteranów wojny wietnamskiej czy afgańskiej, ale czterech osób, z których każda ma doświadczenie i chce wnieść do dyskusji wiedzę na tematy nas interesujące. Wszyscy zgodnie przyjęli zaproponowany przez Pana Profesora porządek i każdy z nas przez ok. 3 minuty musiał opowiedzieć coś o sobie i swoich doświadczeniach praktycznych i akademickich. Od razu zauważyłem, że osoby reprezentują odmienne doświadczenie i zainteresowania i że każdy z nas mógł wnieść do dyskusji inne doświadczenie i spojrzenie na problematykę rynku kapitałowego w kontekście instytucjonalnym oraz instrumentalnym. Całe spotkanie, tematyka i osoby wydawały się nieprzypadkowe, przy okazji jakiejś tam pogawędki o zeszłorocznej aukcji koni rasowych w Janowie (choć temat dla mnie osobiście bardzo fascynujący). Były przemyślanym i usystematyzowanym ciągiem zdobywania wiedzy o rzeczach i sprawach, które interesowały naszego głównego dyskutanta.

Przez cały ten kilkugodzinny maraton dyskusyjny ton nadawał Profesor Sopoćko, moderując, zachęcając i stawiając pytania których każdy $\mathrm{z}$ nas $\mathrm{w}$ miarę możliwości przedstawiał swoją argumentację, tezę czy wyjaśniał coś, na czym zależało Profesorowi. W pewnym momencie dyskusji, kiedy omawialiśmy instytucjonalne podstawy funkcjonowania rynku kapitałowego, temat rozmowy wszedł nieco na rolę banku cen- 
tralnego jako tzw. lender of last resort i rolę FED-u jako stabilizatora systemu finansowego. Otóż Profesor postawił tezę, z której z grubsza rzecz ujmując, wynikało, iz bank centralny, jako instytucja „ostatniej szansy" nie tylko powinien się zajmować stabilizowaniem inflacji poprzez tzw. cel inflacyjny w ujęciu monetarystów i dogmatu friedmanowskiego, lecz także powinien dbać o stabilizację całego systemu finansowego. Profesor Sopoćko podkreśli, że jedynie FED jest bankiem wszystkich banków centralnych ze względu na rolę dolara jako światowego pieniądza transakcyjnego, portfelowego i jako rezerwy innych banków centralnych. Profesor podkreślił, z jedynie FED, mający nieograniczone możliwości emisji dolara, jest w stanie dostarczyć wymaganej płynności w sytuacji „wyparowania gotówki” z rynku transakcyjnego. Dzisiaj wydaje się to dość powszechny pogląd (ale nie we wszystkich kręgach w EU i Polsce), szczególnie po kryzysie z lat 2007-2009, ale wtedy, w pierwszej połowie lat 90., dominował jeszcze neokolonialny plan narzucony przez IMF, określany w Polsce jako Plan B i plan Saxsa, oraz poglądy bliskie szkole ortodoksyjnych ekonomistów o konieczności ograniczonego udziału państwa w systemie regulacyjnym i nadzorczym (najlepiej bez nadzoru) i powtarzających regułki niedouczonych ekspertów o „niewidzialnej ręce rynku" i samoregulującym się systemie rynku kapitałowego.

Temat poruszony przez Profesora wydał mi się nie tylko znany z wykładów i seminariów organizowanych przez National Economist Club w Waszyngtonie, którego od roku 1988 byłem członkiem, ale na który poświęciłem sporo czasu, korzystając z zasobów bibliotecznych Johna Hopkinsa U. i z publikacji FED-owskich. Do wywodu Profesora Sopoćko na temat banku centralnego dodałem, iż przypominam sobie, że dr Robert McTeer (były Prezes FED-u w Dallas), chyba w 1989 roku, stwierdził, iz bank centralny w USA (właściwie system banków centralnych) zajmuje się inflacją wtedy, kiedy nie ma nic do roboty, a na pytanie jednego z kolegów (wiceprezydent T. Rowe Price w Baltimore), „To co ma do roboty FED?”, odpowiedział, że niewiele poza rutynową pracą, oraz wykonywaniem tych zadań i funkcji, do których zobowią- 
zuje konstytucja amerykańska. Ponadto podkreślił, że zadaniem FED-u, a takie były intencje ustawodawcy powołującego Rezerwę Federalną, jest dbanie o stabilność systemu finansowego i stabilność cenową. Zupełna zbieżność poglądów Profesora z tym, co na wykładzie przedstawił dr Robert McTeer w 1989 roku.

Byłem zdumiony poglądem Profesora A. Sopoćko w kwestii tak istotnej jak rola banku centralnego w całym systemie finansowo-bankowym, w tym, jak podkreślał Profesor, wyjątkowej roli w zmniejszeniu kosztów i ryzyka funkcjonowania systemu transakcyjnego w sytuacji, kiedy banki wycofują się z rynku pieniężnego. Zatem, kontynuował Profesor, jeżeli mamy zbudować sprawnie funkcjonujący rynek kapitałowy, to rola banku jako stabilizatora systemu finansowego i gwaranta tzw. dostarczyciela płynności musi być uregulowana na poziomie prawnym i instytucjonalnym. Przy okazji dyskusji wyartykułował, że rolą banku centralnego nie jest absorbcja ryzyka rynkowego i działania na rzecz pompowania „taniego pieniądza”, ale jedynie podejmowanie działań w sytuacjach kryzysu systemowego w sektorze bankowym. Na moje pytania, czy bank centralny powinien uczestniczyć w czasowym przejęciu banku komercyjnego w sytuacji pojawienia się bankructwa dużej instytucji finansowej mogącej spowodować efekt „kuli śnieżnej” sugerował, że takie wyjątkowe sytuacje należałoby rozważyć w polskim systemie prawnym. Pan Profesor argumentował, iż ze względu na duże konsekwencje destabilizacji systemu bankowego, utraty społecznego poparcie dla reform państwa, ale także dużych konsekwencji natury społecznej i politycznej taka interwencja byłaby uzasadniona, z punktu widzenia interesu społecznego. Otóż taki dokładnie punkt widzenia reprezentował dr Bob McTeer na wykładzie z polityki monetarnej w 1989 r., podkreślając istotną wagę ryzyka systemowego w sektorze bankowym, oraz ryzyka przenoszenia lub transmisji tego ryzyka na bilanse innych instytucji finansowo-bankowych funkcjonujących na rynku kapitałowym. Tak też postąpił Sekretarz Skarbu USA Timothy Gartner, decydując się na tzw. parasol ochronny i de facto nacjonalizację City Group w 2007 roku. Warto dodać, iz 
na przełomie lat 2007-2008 FED musiał de facto przyjąć na swój bilans firmę giełdową AIG w formule trzech wydzielonych zasobów kapitałowych jako zobowiązania FED.

Interesująca rozmowa trwałaby jeszcze dłużej, ale miałem jeszcze tego dnia inne zobowiązania w Warszawie i poza nią.

Po 4-godzinnym spotkaniu, w dobrych nastrojach, rozstałem się z profesorami, którzy ciągle prowadzili ożywiony dyskurs, na temat giełdy i rynku kapitałowego, ryzyka politycznego i konsekwencji społecznych reform w Polsce.

Dyskusja w tak wybitnym gronie uświadomiła mi, iz Polska ma wybitnych ludzi ze środowisk akademickich i naukowych, którzy z pasją zajęli się przebudową polskiej gospodarki, w której rynek kapitałowy i jego instytucjonalne podstawy zostały dostrzeżone jako czynniki sprzyjające budowie nowoczesnej gospodarki opartej na prywatnym kapitale i na mechanizmach wolnorynkowych wykorzystujących potencjał wszystkich obywateli. Droga ta w praktyce okazała się jednak dość kręta i nie zawsze usłana sukcesami, ale w świadomości wielu z nas pozostaje fakt, iż osoby takie jak Profesor Andrzej Sopoćko i wielu innych, blisko związanych z WZ ( z którymi mogliśmy prowadzić otwarte dyskusje), spełnili swoją pionierską i wyjątkową rolę w przebudowie naszej gospodarki i naszego systemu społecznego w trudnych latach po upadku komunizmu. 


\section{Katarzyna Niewińska}

\section{Dla „ojca naukowego”}

ochany Panie Profesorze,
Do tej pory mam w głowie i pamiętam jakby to było wczoraj... Byłam wówczas doktorantką na drugim roku, jak podczas konferencji przedstawił mnie Pan swojemu koledze jako „córkę naukową”. Ten niezwykły komplement cały czas brzmi w moich uszach i codziennie mnie motywuje do pracy.

Przypadł mi niezmierny zaszczyt bycia Pana studentką, doktorantką i pracownikiem. Jest Pan człowiekiem nieszablonowym, pełnym poczucia humoru, a zarazem o ogromnym sercu. Naszą historię opisałam w krótkim prostym wierszyku, wiedząc jak bardzo Pan nie lubi, kiedy jest zbyt sztywno i formalnie.

Profesor Sopoćko jubileusz dziś obchodzi, cieszy się cała akademicka rodzina, a w szczególności „córka naukowa” Katarzyna, oprócz niej cieszy się cudowna żona, dwójka dzieci oraz wnuczka Sonia. 
Choć na pierwszy rzut oka jest surowy,

To trzeba przyznać, że człowiek to wspaniały i wesoły.

Najlepsze Andrzejki organizuje,

Wróżby wymyśla i wciąż dowcipkuje.

Przez całą karierę poważne stanowiska zajmował, a ludzi i swoich pracowników zawsze szanował Ciekawe książki nam wszystkim proponuje i w języku niemieckim zawsze „króluje”.

Jak lew o swoich ludzi walczy, kocha kabarety i żarty.

Dowcipy z rękawa wytrzepuje, Zawsze wszystkich bawi i w towarzystwie bryluje.

Kocha zwierzęta, a pies jest najważniejszy.

Choć sam mięsa nie kosztuje,

Gdy pies chory cielęcinę przygotowuje.

Rynek kapitałowy każdemu studentowi wbija do głowy.

Mój pierwszy z nim egzamin był przełomowy.

30 osób oblanych, kryzys w wiedzy przyswajania...

Szczerze przyznać muszę, że złą passę przełamałam

I ocenę pozytywną wówczas dostałam.

Później pracę magisterską u Profesora pisałam,

A propozycję doktoratu e-mailem otrzymałam.

Wspólnie z Patrycją mnie motywowali...

I co najgorsze krótkie terminy zaliczeń mi wyznaczali.

Teraz już wspólnie pracujemy...

Od kilku lat także wspólnie egzaminujemy 
$\mathrm{Na}$ początku studenci od profesora uciekali,

A na egzaminy do mnie i Renaty się zapisywali.

Dziśs role się odmieniły,

to profesora wybierają

i od nas uciekają...

Taki szef to skarb.

Naukowiec wielki

i wspaniały człowiek.

Cieszę się bardzo, że z profesorem pracuję

i za wszystkie wspólne lata mu dziękuję...

Katarzyna 


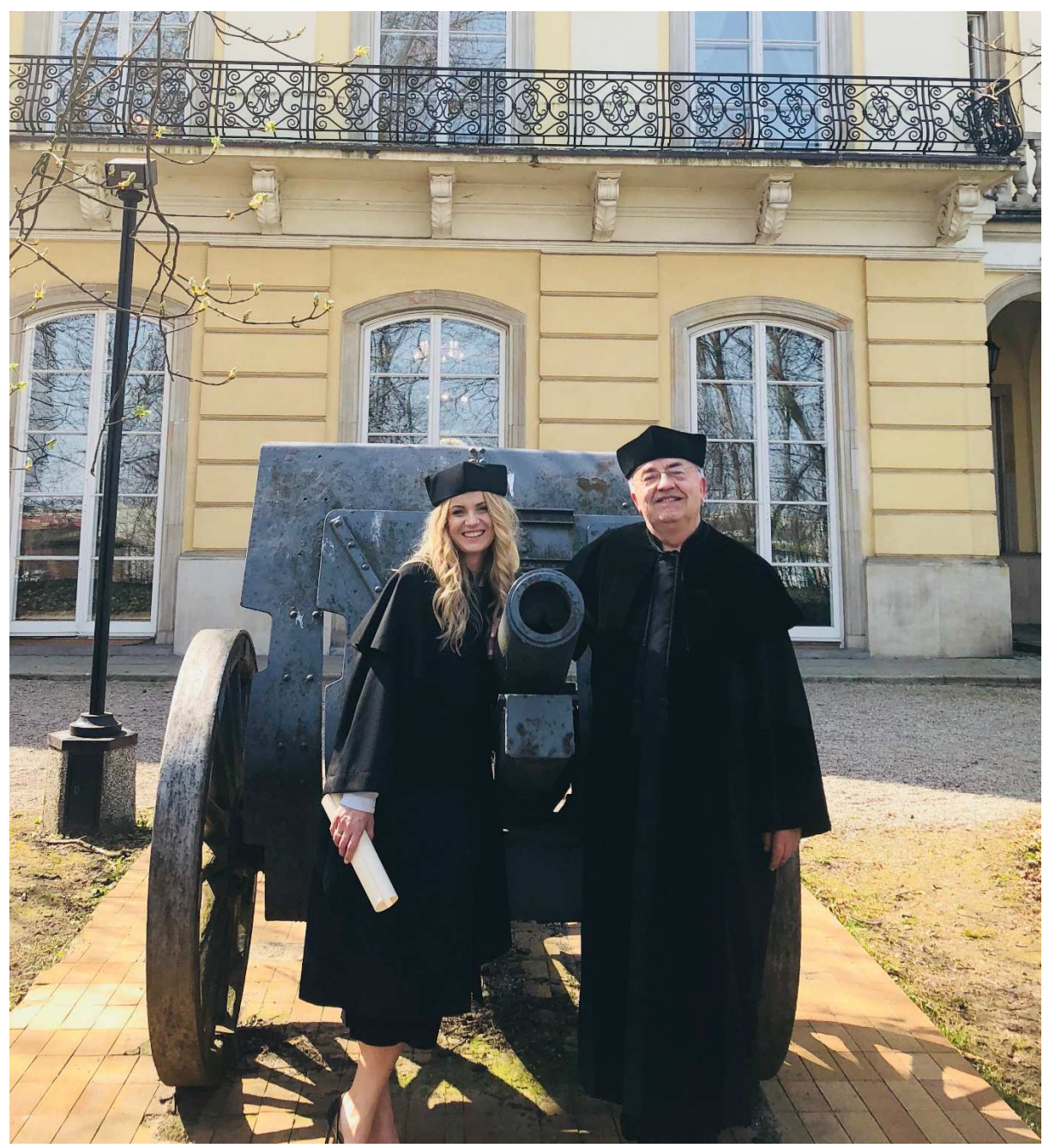

Rozdanie dyplomów na Uniwersytecie Warszawskim, Krakowskie Przedmieście, Warszawa.

Profesor Andrzej Sopoćko z Kasią Niewińską

Fot. A. Niewiński. 


\section{Anna Popiołek}

\section{Profesor nie tylko od finansów}

Teszcze w studenckich czasach, podczas wykładów z bankowości i rynków kapitałowych, Pan Profesor dał się poznać jako świetny fachowiec.

Dla nas, dopiero poznających akademicki świat, bogate doświadczenie zawodowe Profesora niektórych wręcz paraliżowało. Wydział Zarządzania ma wybitną kadrę, ale mało kto mógł się pochwalić prezesurą w Urzędzie Ochrony Konkurencji i Konsumentów, wiceprezesurą Giełdy Papierów Wartościowych, pełnieniem funkcji doradcy ministra, potem premiera, a w końcu oddelegowaniem na stanowisko wiceministra finansów.

To robi wrażenie.

Profesor Andrzej Sopoćko miał opinię profesjonalisty, surowego, ale sprawiedliwego pedagoga. Podczas egzaminów nie można było liczyć na taryfę ulgową, a braki w przygotowaniu Profesor rozpoznawał bezbłędnie już po kilku chwilach. Wtedy egzamin trwał zaledwie 2 minuty i student od razu wiedział, że czeka go „kampania wrześniowa”.

$Z$ drugiej jednak strony nie trzeba było być erudytą, wystarczyło trzymać się mocno faktów - to zupełnie inaczej niż u niektórych innych 
wykładowców, gdzie braki w przygotowaniu można było markować elokwencją i wygadaniem.

Kiedy jesienią 2015 r. zdecydowałam się złożyć aplikację na studia doktoranckie na Wydziale Zarządzania, Profesor Sopoćko zasiadał w komisji egzaminacyjnej.

- A u kogo chce pani pisać ten doktorat? - zapytał członek komisji.

- U Profesora Sopoćko - odpowiedziałam, co wywołało niemałe zaskoczenie członków komisji i samego Profesora, który zupełnym przypadkiem znalazł się akurat w tej komisji rekrutacyjnej.

Chciałam zająć się czymś, czego nikt inny przede mną nie zrobić - prześwietlić konstrukcję ubezpieczeń dołączanych do kredytów konsumpcyjnych, a tak się szczęśliwie składa, zee Profesora jest przecież specjalistą w tej dziedzinie.

Profesor już podczas rozmowy rekrutacyjnej wyraził zgodę. I tak z powrotem zasiadłam już tym razem w doktoranckich ławach Wydziału Zarządzania.

Podczas kolejnych spotkań przygotowawczych do pisania dysertacji (już bez obecności pozostałych członków komisji rekrutacyjnej) ustalaliśmy szczegółowy plan pracy i badań. Obawiałam przestawienia na język naukowy, akademicki - fachowy, ale mało wciągający, hermetyczny. Dla Profesora jednak najważniejsze było to, żeby pisać językiem prostym, zrozumiałym, przejrzystym. Z tym problemu nie było, mogłam wykorzystać mój warsztat dziennikarski, czyli to, czego nauczyli mnie redaktorzy „Gazety Wyborczej”.

- Trzeba pisać prosto, jeśli rozumie się dany mechanizm, to jest się w stanie wytłumaczyć jego działania w bardzo przystępny sposób, zrozumiały również dla tych, którzy nie są specjalistami w tej dziedzinie - przekonywał mnie Profesor Sopoćko.

I rzeczywiście, identyczną zasadę stosował podczas pisania swoich artykułów. Mimo że poruszał skomplikowane kwestie - jak w ostatniej 
publikacji Mit pieniądza zaproponował wprowadzenie dodatkowego strumienia przepływu pieniędzy dla inwestycji rządowych - całą teorię potrafił przedstawić w tak przystępny sposób, że bez trudu zawiłe meandry polityki monetarnej zrozumiałyby czytelnik - za przeproszeniem - zółtej prasy, czyli sensacyjnych i niewymagających gazet. To jest dopiero sztuka!

W trakcie pracy nad kolejnymi rozdziałami, ich poprawkami, szlifowaniem, Profesor cały czas przypominał mi, że na doktoracie świat się nie kończy. Przez cały czas inspirował mnie innymi zagadnieniami gospodarczymi, że wspomnę tylko kwestię automatyzacji rynku pracy. To wyzwanie na miarę XXI wieku, które kto wie, może skończy się wprowadzeniem bezwarunkowego dochodu?

O tym, że za drzwiami auli też jest świat, Profesor przypominał mi, kiedy $\mathrm{w}$ trakcie dyżuru zamiast rozprawiać o roli bancassurance $\mathrm{w}$ rozwoju rynku ubezpieczeń, potrafił ni z tego, ni z owego otworzyć album malarstwa XIX w. i dyskutować o sztuce. Albo zachwalał swoją włoską alfę romeo, co ja, miłośniczka angielskiej motoryzacji, przyjmowałam z całkowitym niezrozumieniem...

Ghandi powiedział, że stopién rozwoju cywilizacji wyraża się stosunkiem człowieka do zwierząt. Jeśli to prawda, to Profesor Sopoćko wyprzedza naszą cywilizację. U niego $\mathrm{w}$ domu - jakże by inaczej nie mogło zabraknąć pupila, który ma status równoprawnego członka rodziny.

Do dziś zżerają mnie nerwy na myśl o moim pierwszym egzaminie w życiu. Ale nie tym, kiedy odpowiadałam, ale kiedy to ja przepytywałam. Egzaminowanie kilku pierwszych studentek z operacji otwartego rynku było dla mnie z pewnością bardziej stresujące niz dla nich. Emocje opadły dopiero, kiedy Profesor Sopoćko wrócił do sali i dał do zrozumienia, że nie ma co się bać: sprawa jest prosta - albo ktoś umie i zdaje, albo nie ma co się starać za niego. 
Profesor jednak potrafi też zaskoczyć. - Aniu, czy możesz podjechać na egzamin z finansów na konferencję Wydziału Zarządzania? - zapytał mnie. W ciemno odpowiedziałam, że oczywiście. Dopiero później okazało się, że wydziałowy kongres co roku odbywa się w innym miejscu, a tym razem padło na zupełnie nieznane mi Smardzewice. Dopiero za pomocą mapy zorientowałam się, na co się zgodziłam - całkiem niebliski wypad aż pod Tomaszów Mazowiecki.

Jak się później dowiedziałam, historia o pewnej studentce, która to pokonała $120 \mathrm{~km}$, na krótki egzamin wzbudzała zaintrygowanie i wesołość sporej części wykładowców.

Pamiętam to dokładnie - odpowiadanie na pytania dotyczące budżetu i rachunkowości w oparach stołówki Centrum Konferencyjno-Rekreacyjnego „Molo”, wśród stuku talerzy i kubków z kompotem - to niezapomniane doświadczenie, nie tylko dla mnie, ale zapewne dla całej komisji. Jest to wspomnienie tym bardziej miłe, że przez egzamin przebrnęłam wzorowo.

I tak - dzięki takiej niekonwencjonalnej determinacji Profesora obroniłam się jako pierwsza ze wszystkich studentów z mojego rocznika. Ba, jako pierwszej na Wydziale udało mi się zdobyć tytuł doktora nauk ekonomicznych w dziedzinie finanse. Gdyby nie upór i doping Pana Profesora, to podobnie jak moje koleżanki i koledzy, z obroną mogłabym zwlekać kolejne miesiące, jak nie lata i zostać wieczną studentką.

Sukces wcale nie przyszedł łatwo, ale był okupiony ciężką pracą i wieloma wyrzeczeniami. W końcu musiałam połączyć pisanie pracy doktorskiej z codzienną pracą w „Wyborczej”. Bez jego zapału i pewności, że to, co robię, jest dobre, nie znalazłabym motywacji do zarywania kolejnych nocy na pisanie doktoratu. 


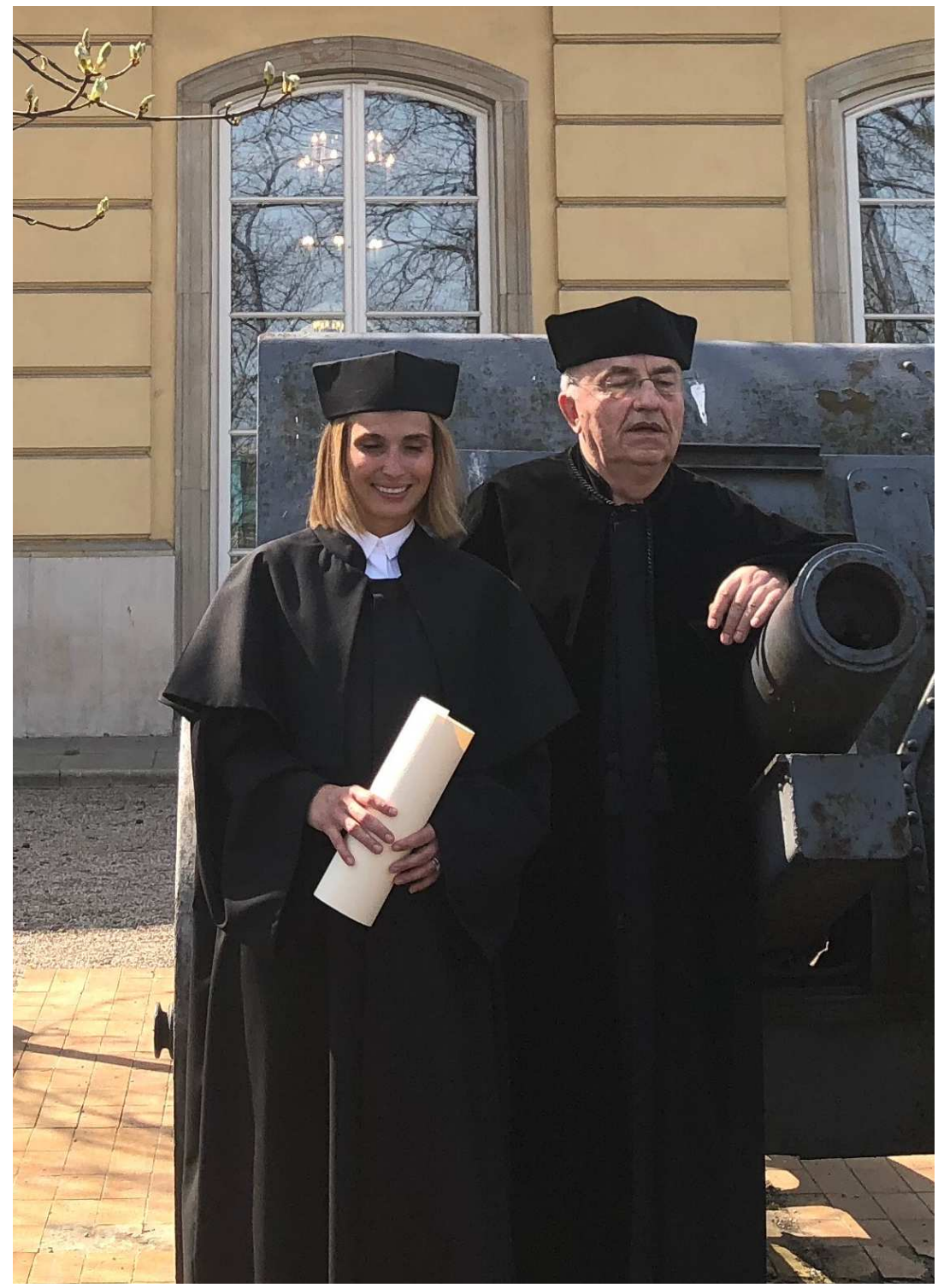

Rozdanie dyplomów na Uniwersytecie Warszawskim, Krakowskie Przedmieście.

Profesor Andrzej Sopoćko z Anią Popiołek Fot. K. Niewińska. 


\section{Andrzej Rutkowski}

\section{O Profesorze Andrzeju Sopoćko}

Drofesor Andrzej Sopoćko był promotorem mojej rozprawy doktorskiej. W trakcie jej przygotowania udzielił mi wręcz nieocenionego wsparcia. Dużo czasu spędziliśmy, dyskutując zagadnienia finansów i inwestycji przedsiębiorstw.

W swojej pracy akademickiej Andrzej jest otwarty na problemy młodych adeptów nauki, doktorantów oraz tych aspirujących do kolejnych stopni naukowych. Z ogromną życzliwością odnosi się do ich pomysłów. Próbuje znajdować w ich pracach pozytywne aspekty, które należałoby uporządkować i rozwinąć. W pewnych sytuacjach nie unika jednak zdecydowanych zdań krytycznych. Korzysta ze swojej specjalistycznej wiedzy i interdyscyplinarnego doświadczenia. Ma dar syntetycznego i naukowego opisu badanych zjawisk i dyskutowanych problemów.

Andrzej był i jest zaangażowany w wiele różnych przedsięwzięć. Zachęcał nas życzliwie do podjęcia z nim wspólpracy w wielu miejscach. Stanowiło to doskonałą okazję do zdobycia wiedzy i doświadczenia potrzebnego do prowadzenia działalności akademickiej. 
Andrzej jest osobą bardzo serdeczną, chętnie rozmawia o sprawach osobistych naszych rodzin, o naszych codziennych troskach. Przyznam się, że z pewnym zdziwieniem dowiadywałem się od Niego o problemach związanych z wychowywaniem dorastających dzieci. Chwilę później sam je przeżywałem i z rozbawieniem wspominałem wówczas jego uwagi. Dopiero później je zrozumiałem. Doszło do mnie, że w pewnym okresie, $\mathrm{w}$ sposób naturalny trudno jest porozumieć się z dziećmi. Trzeba to cierpliwie przetrwać.

Andrzej jest miłośnikiem zwierząt, a w szczególności psów. Wymienialiśmy się uwagami, jak należy je traktować. Ja w pewnym czasie miałem jamnika, a on dużego wilczura. Andrzej odkrywał przede mną tajniki psychologii dużych i małych czworonogów. Zgodnie z jego radami, duże psy należy traktować jak małe pieski wymagające szczególnej troskliwości. Natomiast do małych należy się zwracać jak do dużych groźnych psów. 


\section{Patrycja Chodnicka-Jaworska}

\section{Mite chwile $z$ Profesorem}

Dan Profesor Andrzej Sopoćko, Andrzej... wiele można byłoby pisać o tej postaci. Pierwszy raz poznałam Profesora jako pracownika naukowego Wydziału Zarządzania Uniwersytetu Warszawskiego, gdy prowadził z moim rokiem zajęcia nt. „Rynki finansowe”. Zawsze niezwykle uśmiechnięty, pogodny, życzliwy człowiek z ogromną wiedzą, a przede wszystkim umiejący zarazić chęcią do pracy. Pamiętam, jak większość moich kolegów i koleżanek trzęsła się ze strachu przed egzaminem ustnym. Cały hol, wchodziliśmy trójkami, trzy pytania. Moje były następujące: Co to jest rynek zorganizowany?; Akcje i ich rodzaje?; Wycena opcji metodą Blacka-Scholsa?. Tyle lat a ja jeszcze pamiętam (-). Odpowiedziałam, po czym dostałam pytanie, czy nie zastanawiałam się nad studiami doktoranckimi na Wydziale. Szczerze mówiąc, wtedy jeszcze się nie zastanawiałam, ale z pewnością rynek finansowy zaczął mnie interesować. Kolejnym miejscem, gdzie spotkałam Profesora, była Giełda Papierów Wartościowych w Warszawie. Zajęcia prowadzone bowiem przez Andrzeja skłoniły mnie do rozpoczęcia pracy na GPW. Pamiętam, pracując w gabinecie Prezesa, któregoś pochmurnego dnia 
dostałam dokumenty do weryfikacji. Przed ich otwarciem otrzymałam od koleżanek informację, że to, co zobaczę bardzo mnie przytłoczy. Okazało się, że jest to dokumentacja Fundacji, w której zebrano wnioski złożone przez rodziców bardzo chorych dzieci. Zdjęcia w niektórych przypadkach makabryczne. Zaawansowane przypadki różnych chorób. Ujęły mnie wtedy notatki Andrzeja, napisane odręcznie, z wyrażonymi pozytywnie decyzjami, w niektórych przypadkach ze wskazaniem dodatkowego źródła finansowania. Na Andrzeja zawsze można liczyć... Gdy sama zachorowałam, wielokrotnie oferował mi swoją pomoc, pamiętam, jak chciał chodzić za mnie na ćwiczenia, gdzie przecież Profesorowi nie wypadało...

Andrzej to również człowiek bardzo rozrywkowy, chyba wszyscy pamiętają kabarety z jego udziałem. Tradycją Wydziału stało się coroczne wystąpienie Andrzeja wraz z grupą teatralną $:$.

$\mathrm{Na}$ polu zawodowym miałam okazję wspólpracować z Andrzejem w kilku kwestiach. Po pierwsze jako promotor pomocniczy pracy ówczesnej mgr Katarzyny Niewińskiej, która notorycznie przeżywała zawał, gdy widziała telefon od któregoś z nas, a miała powody, bo aby ją zmobilizować, dzwoniliśmy z następującym rodzajem informacji „Kasiu masz dwa tygodnie za zakończenie pracy doktorskiej, bo chcemy postawić pracę pod głosowanie Rady Wydziału celem ustalenia recenzentów”; „Kasiu za dwa tygodnie masz egzamin doktorski” itp. Podobno w tamtym czasie wspomniana Kasia żywiła się przede wszystkimi lekami uspokajającymi, ale dała radę $:-$. Brałam też udział wraz z Andrzejem w kilku konferencjach, np. WROFIN czy Konferencji Katedr Finansów. Okazało się, że Andrzeja wszyscy znają, cenią i bardzo lubią. Zazwyczaj krążyła opinia, że to między innymi z jego książek uczono się na temat rynku kapitałowego. Z kolei na konferencji w Bilbao organizowanej przez UPV i University of Cambridge stał się przyjacielem wszystkich, a ze Stephany Griffith-Jones, Hasse Ekstedtem, Haraldem Sanderem i Philipem Arestisem przegadaliśmy cały wieczór. Pamiętam również, że przed samym wylotem do Polski, nie myśląc o sobie, myślał o żonie, 
że musi kupić jej torbę, bo on to żyje skromnie, ale lubi sprawiać przyjemność swojej żonie. I mimo że zaraz miał samolot, poleciał do sklepu w poszukiwaniu rzeczonej torby $(;)$.

Andrzeju, zawsze będę miała same dobre skojarzenia z Twoją osobą, jako człowiekiem bardzo życzliwym, kochającym swoją rodzinę, elokwentnym, z ogromnym poziomem wiedzy, a przede wszystkim ludzkim. Ogromną przyjemnością jest z Tobą pracować. Mam nadzieję, że następne lata będą równie udane.

SERDECZNOŚĆ... :) 
Jakub Górka

\section{Profesor Andrzej Sopoćko w moich oczach - profesor i czlowiek o wielu talentach $i$ zainteresowaniach}

U Tkwił mi w pamięci obraz Pana Profesora Andrzeja Sopoćko, który dystyngowanym krokiem przemierza podium w auli głównej Wydziału Zarządzania Uniwersytetu Warszawskiego, opowiadając w ramach wykładu o giełdzie i rynkach kapitałowych. Byłem wówczas studentem studiów magisterskich. Profesor Sopoćko przychodził na wykłady rankami w środy, mimo że w owym czasie pełnił funkcję wiceministra finansów i z pewnością obowiązków mu nie brakowało. Wykłady były ciekawe również dlatego, że Profesor z właściwym sobie temperamentem okraszał je licznymi komentarzami na temat swojej bieżącej działalności i aktualnej sytuacji gospodarczej. Obrywało się na przykład Radzie Polityki Pieniężnej i Narodowemu Bankowi Polskiemu, który w mniemaniu Profesora mógł skuteczniej wspierać politykę rządu. Co ciekawe, mimo że niekonwencjonalne narzędzia polityki pieniężnej, takie jak luzowanie ilościowe, banki centralne zaczęły stosować dopiero po upadku Lehman 
Brothers w 2008 r. i w następstwie kryzysu finansowego, to już pięć lat wcześniej Profesor Sopoćko wysuwał postulat, że bank centralny w razie potrzeby może skupować papiery skarbowe z rynku wtórnego i w ten sposób zasilać gospodarkę w pieniądz i wspierać wzrost gospodarczy.

Znamienne dla Andrzeja Sopoćko, że jego zainteresowania badawcze były zawsze szerokie. Wprawdzie specjalizował się w giełdzie i rynkach kapitałowych (a po okresie urzędowania jako wiceminister finansów przeszedł do zarządu Giełdy Papierów Wartościowych w Warszawie), niemniej jednak zgłębiał także materię finansów publicznych, ubezpieczeń i kwestie monetarne.

W tym ostatnim obszarze miałem możliwość uczestniczyć w kilku ciekawych seminariach organizowanych przez Pana Profesora Sopoćko, na które zapraszał najlepszych polskich ekonomistów. Owocem jednej z nich była moja publikacja z 2008 r. pt. Przystapienie Polski do strefy euro $w$ kontekście programów SEPA i SECA, która znalazła się w redagowanej przez Profesora Sopoćko monografii pt. Polska $w$ strefie euro? Nowe perspektywy wzrostu.

Zainteresowanie Profesora Sopoćko ubezpieczeniami spowodowało wzrost znaczenia tej gałęzi pośrednictwa finansowego na naszym wydziale. Nawet nazwa kierunku studiów „Finanse i Rachunkowość" została poszerzona o człon „ubezpieczenia” i brzmi aktualnie „Finanse, Rachunkowośc i Ubezpieczenia" - dowód na moc sprawczą Profesora Sopoćko także w programach kształcenia na Wydziale Zarządzania UW.

Moja znajomość z Profesorem Sopoćko rozwinęła się na niwie nie tylko naukowej w ramach pracy Katedry Systemu Finansowego Gospodarki, ale także... rozrywkowej.

Andrzej Sopoćko jest profesorem nauk ekonomicznych, ipso facto, ale i człowiekiem o wielu innych talentach i zainteresowaniach. Może imponować jego rozległa wiedza o starożytnym Egipcie i umiejętności towarzysko-rozrywkowe. Profesor stworzył niezapomniane kabarety, które przez ostatnie lata po całodniowych dysputach merytorycznych dorocznych konferencji Wydziału Zarządzania UW bawiły nas na imprezach 
wieczornych. W jednym z kabaretów w 2013 r. sam występowałem, witając się na misia z Profesorem jako Przywódca Sklawinii Bolesław w scence „Zjazd Gnieźnieński”. Profesor Sopoćko wcielił się w rolę Ottona III Przywódcy Germanii.

Śmiechu było co niemiara, gdy z Robertem Pietrusińskim i Adamem Chmielewskim przygotowaliśmy się na próbach do skeczów: „Casting na posadę”, „Szmonces”, czy „Reprezentant Polski”. Profesor Sopoćko dyrygował, sam wcielał się w niektóre role, ale przede wszystkim pisał scenariusz i przygotowywał teksty. Teksty, w których uwidaczniał się Jego niesamowity talent do aranżacji faktów historycznych z sytuacją polityczną, sportową i gospodarczą w Polsce i Europie. Profesor Sopoćko potrafi wspaniale grać językiem i znaczeniami, żonglować słowami, ironizować, rozśmieszać porównaniami. Ale żeby zrozumieć niektóre żarty, trzeba było dobrze rozeznawać się w ich kontekście, a puenta nie była niekiedy podawana na tacy, lecz wymagała refleksji i wysiłku intelektualnego.

Andrzeju, z okazji jubileuszu 70. urodzin życzę $\mathrm{Ci}$ zdrowia i takiej formy, jaką masz obecnie! Żebyś był pełen pomysłów i werwy, działał naukowo i wciąż żartował! 


\section{Piotr Jaworski}

\section{Profesor Andrzej Sopoćko - kilka stów}

Drofesor Andrzej Sopoćko, znany jako człowiek instytucja, jeden z prekursorów podręczników i praktyk rynkowych w zakresie rynku kapitałowego, ale przede wszystkim człowiek osobny, który w swym postępowaniu kieruje się jasnymi kryteriami intelektualnymi, naukowymi i etycznymi. Niekwestionowany autorytet, budzący wiele sympatii wśród szerokiego grona naukowców oraz finansistów funkcjonujących na rynku. Jako człowiek - niezwykle życzliwy i wspierający, rozumiejący ludzkie problemy. Prywatnie osoba o ogromnym poczuciu humoru. Dusza towarzystwa.

Pasja podróżowania i wpleciona w nią ciągła chęć poznawania tego, co nowe i jeszcze nieznane zarówno na niwie naukowej, jak i w innych obszarach, znalazła swoje odzwierciedlenie w powadze, jaką Profesor nadaje współpracy naukowej. Jego docenianie tejże współpracy przekłada się również na troskę i zainteresowanie, którymi otacza swoich studentów 
i doktorantów. Zawsze mogą oni liczyć na jego wsparcie i pomoc, bez względu na kraj i kontynent ich pochodzenia.

Z okazji Jubileuszu wszystkiego co najlepsze, co dobre i miłe, co budzi uśmiech na twarzy, co kryje się w maleńkim słowie - szczęście oraz tradycyjnych 100 lat, 
Waldemar Kozioł

\section{Moje spotkania z Profesorem Andrzejem Sopoćko}

Drofesor Andrzej Sopoćko to jedna z legend Wydziału Zarządzania. Osoba, która w dużej mierze kształtuje jego oblicze. Jest powszechnie szanowana przez studentów i przez pracowników. Jest to wynikiem zarówno osobowości Profesora Andrzeja Sopoćko, jak i jego olbrzymiej wiedzy.

Mówiąc o osobie Profesora Andrzeja Sopoćko, trudno jest wskazać jakieś jedno zdarzenie, anegdotę, która najlepiej by go charakteryzowała. Spróbuję więc posłuzyć się krótkimi impresjami czy może raczej fotografiami.

\section{Profesor}

Pierwszy kontakt z Profesorem Andrzejem Sopoćko to oczywiście moje czasy studenckie. Zajęcia $\mathrm{z}$ rynku kapitałowego $\mathrm{z}$ jednym z założycieli rynku to było przeżycie. Zajęcia z wiceprezesem giełdy 
w okresie, kiedy każdy, no może prawie każdy, chciał być maklerem, doradcą inwestycyjnym, to było wydarzenie... no i autorem pierwszego polskiego podręcznika o giełdzie. Wiedza, anegdoty i dystans do samego siebie, to budowało autorytet wśród studentów. No i co oczywiste sam egzamin też... Każdy do dziś pamięta. A Profesor Andrzej Sopoćko to wymagający, ale sprawiedliwy egzaminator...

\section{Kolega}

W trakcie studiów doktoranckich prof. Alojzy Z. Nowak, jeszcze jako prodziekan, zaangażował mnie do pracy przy uruchomieniu programu studiów w języku angielskim, które znane są dziś pod nazwą IBP (słabej znającym Wydzial - angielska nazwa studiów to International Business Program - właśnie IBP). Nie było zbyt wielu chętnych do prowadzenia zajęć w tym języku. I właśnie Profesor Sopoćko był tym, który jako jeden z pierwszych zaofiarował się prowadzić zajęcia z rynku kapitałowego. Nie było wtedy żadnych specjalnych zachęt finansowych, a domyślam się, że przygotowanie się do 30-godzinnego kursu było solidnym dodatkowym wysiłkiem... Ale wtedy, gdy mieliśmy 8-10 przedmiotów po angielsku rocznie (w tym prowadzonych przez visiting profesorów) było to szczególnie ważne. Budowało podstawy pod umiędzynarodowienie Wydziału, które dziś jest jednym z największych w Polsce i w całym regionie Europy Środkowej. To dzięki tym działaniom w konsekwencji mogliśmy po 15 latach uzyskać prestizowe akredytacje. A wtedy na początku XXI w. Wydział Zarządzania bardzo tego potrzebował i Profesor Sopoćko chciał i potrafił na tę potrzebę odpowiedzieć. Więcej: zaoferował gotowość prowadzenia zajęć w języku niemieckim i do dziś żałuję, że z oferty tej nie udało się skorzystać. Jak bardzo można liczyć na Profesora Sopoćko pokazuje kolejna aktywność... 


\section{Organizator}

Rok po obronie doktoratu prof. K. Ryć i prof. A.Z. Nowak powierzyli mi kierowanie programem angielskim i rozwój współpracy międzynarodowej, w tym wymiany studenckiej. Oferta dla studentów zagranicznych była wtedy bardzo mizerna. Wsparcie otrzymywaliśmy tylko od pracowników naukowych i administracyjnych tak Wydziału, jak uniwersyteckiego Biura Współpracy z Zagranicą. Nie było jeszcze programów opiekunów dla studentów zagranicznych, tzw. buddies, i Profesor Sopoćko wpadł na pomysł organizowania wycieczek do różnych firm i instytucji, przede wszystkim do Warszawskiej Giełdy Papierów Wartościowych. Budowało to też szacunek dla Profesora ze strony studentów zagranicznych. A jednocześnie podnosiło w ich oczach, i oczach władz uczelni partnerskich, pozycję Wydziału. Wtedy byłem tym bardzo zaskoczony. Z dzisiejszej perspektywy wydaje mi się to właśnie dla osoby Profesora Sopoćko bardzo naturalne. I kiedy wydawało mi się, że wiem już prawie wszystko, pewnego wiosennego dnia kilka lat temu zostałem zaskoczony...

\section{Pasjonat}

Profesor Sopoćko zapytał, czy w ramach wyjšć ze studentami może ich zabrać do... Muzeum Motoryzacji i Techniki w Otrębusach koło Brwinowa. Jak się domyślam, bo nigdy nie było okazji o tym porozmawiać, to jedna z pasji Profesora... Jedna z licznych... rynek kapitałowy, historia, Wydział Zarządzania...

Wiem, że nie powiedziałem wszystkiego. Ale czy można o takiej osobowości powiedzieć wszystko? $\mathrm{Na}$ pewno nie. Przecież od kilku lat sąsiadujemy drzwi w drzwi. I zawsze, kiedy się widzimy na korytarzu, to niezależnie od okoliczności można liczyć na życzliwe i dobre słowo od starszego i szanowanego Kolegi. Oby jak najdłużej. 


\section{Piotr Sokół}

\section{Trzy zdarzenia}

Drzypominanie sobie o zdarzeniach $z$ lat ubiegłych jest bardzo trudne. Z perspektywy czasu przychodzi taka myśl - warto robić notatki. Jednak w natłoku wydarzeń jest to praktycznie niewykonalne.

Profesora Andrzeja Sopoćko pamiętam w trzech sytuacjach.

Pierwsza związana była z moimi studiami. Profesor był w końcówce lat 70. wykładowcą przedmiotu „Metody i techniki organizatorskie”. Przypominam sobie wykłady prowadzone jeszcze przy ulicy Długiej. Ciekawy temat, sala pełna rozgadanych studentów (na roku było wtedy 120 studentów) i panujący nad tym wszystkim Profesor A. Sopoćko.

Druga dotyczy lat 80 . i związana jest z budynkami Wydziału Zarządzania przy ulicy Szturmowej. Wtedy zimy były zimami nie tylko z nazwy. W czasie jednej z nich przestało na Wydziale działać centralne ogrzewanie. Zrobiło się zimno i z punktu widzenia niektórych studentów mogło to być pozytywne, bo jest powód do odwołania zajęć. Wówczas wkracza Profesor Andrzej Sopoćko i uruchamia swoje kontakty z elektrownią i nagle staje się cud - na Wydziale robi się ciepło. 
Trzecia dotyczy klasycznej cechy kadry profesorskiej - roztargnienia. Był taki okres, kiedy w czasie spotkań Profesor zadawał mi masę pytań z problematyki zarządzania finansowego. Przyznaję, że nie jest to dziedzina moich zawodowych zainteresowan, ale starałem się na wszystkie odpowiadać. Perspektywa następnych spotkań dawała mi impuls do bliższego zgłębienia obszaru finansów przedsiębiorstwa. Mogło by to trwać dłużej, gdyby nie to, że Profesor w pewnym momencie powiedział, że pomylił się, bo brał mnie za Andrzeja Rutkowskiego (obaj mieliśsmy wtedy wąsy, no i mogliśmy być trochę do siebie podobni), z którym te problemy chciał konsultować. 



\section{Wspomnienia, idee, marzenia...}





\section{Monika Kostera}

\section{Wino z Ważka}

Q łońce prażyło, wydobywając z ziemi zapach obietnic i snów, prawie bezchmurne niebo otwierało się nad nimi śródziemnomorskim błękitem, kolorem, którego żadne z nich nie umiało nazwać, ale który rozpoznaliby zawsze i wszędzie, nawet gdyby dotknęła ich amnezja albo obudzili się nagle $\mathrm{w}$ innym stuleciu, innym wymiarze. Pies z puszystą kitą wskoczył do przewróconego pojemnika na śmieci i z taką czystą i szczerą radością buszował w środku, entuzjastycznie falując na zewnątrz ogonem. Spojrzała na niego i uśmiechnęła się. On też się uśmiechnął. Pies pomachał im raz ogonem na odchodne i pobiegł w poszukiwaniu następnego śmietnika i kolejnej przygody.

Opuścili jasną ulicę i schronili się w jednym z bocznych zaułków wielkiego targowiska, przysłoniętego od góry płachtą dającą miły półmrok. Weszli do kawiarenki ukrytej za wielką ladą uginającą się od towarów, przywitani przez starszego pana w tunice sprzedawcy wina. Usiedli w niewielkim, ale pustym o tej porze pomieszczeniu i po chwili już pili pyszną herbatę pachnącą korzeniami i czymś jakby wnętrzem rzadko otwieranej starej szafy. 
„Przydałby się lód do tej herbaty”, powiedział i parsknął śmiechem.

Zaśmiała się. Odgłosy bazaru w tle, za miękką ścianą z tkanin i musujących mrocznym kurzem dywanów mieszały się z dobywającą się skąd’́ cichą muzyką. Tej muzyki chyba najbardziej jej brakowało. Bo na pewno nie dywanów. Dywany mogłaby spokojnie zapomnieć.

„Przepraszam”, powiedziała, już poważniejsza, „przepraszam, że wtedy nawaliłam. Zagadałam się z kotami i jak wreszcie dotarłam z tą książką dla ciebie, to ciebie już nie było... pani herbaciarka powiedziała, że dosłownie, że przed chwilą..."

Uśmiechnął się i pokiwał głową:

„Jak mawiał nasz przyjaciel Symonides: „Człowiekiem będąc, nie wie, co przyniesie jutro, ani jak długo szczęściarz pozostanie szczęściarzem, nasz los tak szybko się odwraca - nawet ważka mniej nagle zawraca«."

„Ważka była bardzo piękna”, powiedziała i wskazała dłonią flakon z winem pod ścianą, „ale to z psem też jest dobre”.

Znów się zaśmiał, kiwając energicznie głową.

„Powiem mu to. Ucieszy się. Też myślę, że to niesamowity pomysł z tymi ikonami na wino. Teraz wszyscy mówią, że pies ma kły i że sprawia, że ludzie wyją do księżyca. Tak jakby to zawsze było oczywiste."

„O, ja też lubię te oczywistości”. Niby była poważna, ale oczy się jej śmiały. „Wiesz, czasami sobie myślę, że cała ta zabawa polega na oczywistościach. W każdym miejscu i czasie wszystko jest oczywiste przez jedną chwilę. A potem już nie jest."

„Potem jest oczywiste, że nigdy nie było oczywiste. Zamówimy sobie po kieliszku tego z psem? Czy wolisz ważkę?"

Sprzedawca, wezwany przez nich zza straganu, zachwalał długo walory obu win. Nie mogła się zdecydować. Do pomieszczenia odgrodzonego ciemnymi stojakami i stołem pełnym towaru, zwróconym w kierunku bocznej uliczki bazaru, wszedł leniwie wielki, czarny kot. Handlarz przerwał swój monolog i zwrócił się do kota, przykucając i wydając z siebie ciąg onomatopeicznych dźwięków. Kot popatrzył 
intensywnie żółtym okiem, nie zdradzając uczuć, ale jednak z wyraźną przyjemnością, otarł się całym ciałem o wyciągniętą w jego kierunku otwartą dłoń starszego mężczyzny.

"No patrzcie państwo, jaki mądry”, sprzedawca znów zwrócił się do swoich gości, promieniejąc dumą, ,patrzcie, gdyby nie Orestes nie miałbym ani tego straganu, ani nawet winnicy. On mi wszystko doradza. On wie i mówi mi we śnie, co uprawiać, co sprzedać."

„Księgarz tam za rogiem ma chyba z pięć kotów i śnią mi się na wyścigi”, powiedziała. Zaśmiali się wszyscy troje. „Myślę, że kot radzi, żeby ważkę."

„O, świetna rada”, ucieszył się handlarz i poderwał w poszukiwaniu kieliszków i otwartej amfory. Po chwili wrócił z tacą pełną smakowitości i dwoma ceramicznymi kieliszkami. Kot otarł się o jego nogi i poszedł położyć się na jednej z puf pod przepierzeniem.

Wypili w milczeniu.

„Wiem, jaka jest ostatnia zwrotka. Przypomniałam sobie”, powiedziała nagle.

Jej rozmówca i kot spojrzeli obaj na nią z wyraźną wdzięcznością. Kot aż podniósł czujnie głowę, choć wydawało się, że już głęboko śpi. Koty mają bogate życie oniryczne i umieją je cenić, wiadomo, że byle co nie wytrąca ich ze snu. Po drugiej stronie półki z winami sprzedawca obsługiwał klientkę, śpiewając jej pieśń o przyprawach. Tak się wczuł, że zaczął kichać. Kot położył z powrotem głowę na łapach i zapadł w sen.

„Strasznie dobre to wino”, powiedziała, a jej towarzysz zamruczał w odpowiedzi i sięgnął po ciasteczko.

Siedzieli tak, pili wino i pogryzali słodycze przez dłuższy czas, wcale im się nie spieszyło, bo dokąd miałoby? Kot spał. Sprzedawca od czasu do czasu podśpiewywał klientom, niektórzy wtórowali, ale większość targowała się tylko o cenę. Taki upadek kultury, co to będzie dalej? Jak będzie się żyć w świecie, gdzie pieniądz straci swą wartość w melodii i wierszu? Zadała to pytanie na głos. Popatrzył na nią z uwagą. 
„Wtedy będziemy musieli się spotkać i zaśpiewać cały wiersz. Razem z ostatnią linijką."

„No tak”, powiedziała, uspokojona. „Bo tylko ta linijka nie jest oczywista."

Popatrzcie na jaskółki na niebie...

i znaki ostrym skrzydłem nakreślone

znaki snu i znaki czuwania, znaki marzeń, znaki nadziei

Czytasz, a rozum pismo $\mathrm{C}_{\mathrm{i}}$ przesłania wraz z lękiem przed mądrości oślepieniem czy zostać więc tylko w pokłonie zapytania?

Kto ma na tyle światła w sobie, że potrafi pojąć? wewnętrzne światło, jak czerwone wino, które zarazem rozjaśnia i ucho nastraja

I kto po żar mądrości sięgnie

bez lęku przed spaleniem duszy, co nie dość świata doznawała wspomni znaki jaskółek, zrozumie ich mowę, tak jak rozumie się muzykę, bo znając język ptaków czytasz mądrości nieba

Błysk oka, błysk nieba, jasność i mrok, wszystko jest częścią wielkiej opowieści, którą snuje czas nierównym rytmem klęsk i nadziei, więc życia oddechem czasami westchnieniem, zawsze tajemnicą a serce puka każdym uderzeniem $\mathrm{w}$ tajemnicy tej bramę 
Stopy tracą przyczepność - gdzie góra, gdzie dół?

Płynę tylko za myślą podaną jak ręka z otchłani, prowadzi, czy w wir mnie pociągnie następnym pytaniem?

Co dla człowieka jest wirem - dla jaskółki jest tańcem, pytania i odpowiedzi jak tancerze na falach i jak pokażesz mi drogę, wirujący drogowskazie?

Jaskółka zwraca, patrzy śmiejącym się okiem, mówi: Pierwszym drogowskazem będzie drzewo.

Drzewo to kochająca ręka Bogini.

Nie patrz na kwiaty. Kwiat jest tylko przynętą pragnących słodyczy, co jej nie zaznali, a teraz są ślepi z pragnienia. Patrz w zieleń grającą ze świattem o klucz do tajemnic zamkniętych przed myślą oczywistością skażoną. Pozwól lotnej zieleni spleść warkocz z ogniem i wodospadem, posłuchaj wiatru, gdy z melodyjnej modlitwy przechodzi w ryk.

Wody świezoośc i światła pląsanie, dusze tworzą radosne, co w przestrzeni płyną Boskim zawołaniem z gwiezdnego pyłu tocząc bałwanki.

Czasami słychać muzykę gwiazd, wtedy dusza śpiewa i zna już odpowiedź, ale czasem pył burzy się i splata jakby świat tonął, jakby śmiał się i tonął. 


\section{Leszek Jerzy Jasiński}

\section{Kraina Ekonomicznej Szczęśliwości}

Tę położoną na wyspie cudowną krainę powinien poznać każdy 1 ekonomista. Niestety, wielu z nich o niej nie pamięta, a gdy jej nazwa powraca w rozmowach, rzadko kto stara się nią bliżej zainteresować. To duży błąd! Maleńka Idealnia jest wyjątkowa: uchodzi za krainę ekonomicznej i społecznej szczęśliwości.

Dociera się tam promem, można też wybrać się helikopterem lub niedużą awionetką. Duże samoloty tam nie lądują, pas startowy na lotnisku jest zbyt krótki. Każdy lot trzeba zgłaszać z dużym wyprzedzeniem. Dlatego najwygodniej podróżuje się promem. Kursuje dwa razy dziennie i dociera do portu, z którego do centrum stolicy tej krainy i jedynego jej miasta jest pół godziny drogi pieszo.

Przystań promowa sąsiaduje z niewielkim portem handlowym i rybackim. Wymiana towarowa Idealnii ze światem istnieje. To, co miejscowe, jest dobrej jakości i w konkurencyjnej cenie. Przyległa do portu dzielnica jest całkiem rozległa i stale tętni życiem.

Już w porcie zobaczycie na maszcie flagę tego kraju. Widnieją na niej trzy kolory: brązowy, zółty i czerwony. Jak głosi wykładnia oficjalna, 
ich wybór nawiązuje do różnych światowych tradycji budowania tego, co życiu gospodarczemu jest szczególnie potrzebne. Co gdzie indziej nie w pełni się udało, przyjęło na Idealnii postać rozwiniętą, stało się rzeczywistością. Trzy barwy odwołują się do trzech zasad, które udało się tutaj pomyślnie wdrożyć; symbolizują one zamożność, efektywność i sprawiedliwość. Nie jest tylko jasne, który kolor należy wiązać z określoną zasadą.

Zaraz za dzielnicą portową zaczyna się centralna część miasta. Układ tworzących ją ulic jest bardzo prosty. Ulica główna zajmuje pozycję podobną do średnicy koła, od niej odchodzą prostopadle ulice krótsze i znacznie węższe. Na ulicy środkowej, noszącej nazwę Wielka Oś, znajdują się eleganckie sklepy, luksusowe restauracje, kino, teatr, redakcja miejscowej gazety; koniec ulicy wyznacza stylowy kościół z wieżą. Boczne uliczki tworzą dzielnicę mieszkaniową, w której osiadła klasa średnia.

Koniec Wielkiej Osi stanowi początek niedużej dzielnicy rządowej. Przedłużenie tej ulicy zmienia nieco dotychczasowy kierunek, arteria komunikacyjna ulega zwężeniu i przyjmuje nową nazwę: Mała Ós.

Struktura idealinijskiego rządu jest bardzo prosta. Nie ma podziału na władze centralne i lokalne. Trzynastotysięczna Idealnia była za mała, by wprowadzić coś takiego. Dwupiętrowy, ciemnoszary budynek mieści biuro i rezydencję prezydenta, obok niego znajduje się dom, w którym pracują ministrowie. W niedużej Idealnii jest ich raptem czterech: spraw zagranicznych, spraw gospodarczych, spraw społecznych i spraw wewnętrznych. Minister spraw zagranicznych nie narzeka na nadmiar pracy: Idealnia prowadzi politykę niezaangażowania, pozostając poza wszelkimi organizacjami międzynarodowymi. Nie pomaga żadnemu mocarstwu, żadnemu nie wchodzi w paradę, w konsekwencji wszyscy zostawiają ją w spokoju. Idealnia nie stanowi raju podatkowego ani pralni brudnych pieniędzy. Minister spraw wewnętrznych też się nie przepracowuje. Do codziennej roboty ma komendantów żandarmerï i policji. Minister spraw socjalnych musi być bardziej aktywny, obo- 
wiązuje bowiem hasło „W Idealnii nikt nie chodzi głodny i obdarty”. Najwięcej zajęć spada na ministra spraw gospodarczych. Gospodarka idealnijska jest w całości sprywatyzowana, ale o dobre warunki funkcjonowania biznesu dba włásnie on. Również on kroi z narodowego bochna chleba środki dla akcji ministra spraw społecznych.

Nie istnieje minister obrony. Jedynym wojskiem tego państwa jest żandarmeria pilnująca dzielnicy rządowej oraz bezpieczeństwa portu i lotniska. Wspiera ją policja działająca na całym obszarze kraju. W sumie żandarmów i policjantów jest stu, o dziesięciu więcej niż urzędników prezydenckich i rządowych, wliczając personel techniczny.

Dzielnica rządowa sąsiaduje z niewielkim obszarem mieszkalnym. Mają tutaj domy wysocy, chociaż nie najwyżsi, urzędnicy i funkcjonariusze państwowi. Do pracy mogą chodzić na piechotę, przyjęło się jednak, że niedługą drogę, choćby liczyła pół kilometra, należy pokonać samochodem.

Dalej zaczyna się park przechodzący w nieduży las. Za nim rozlokowała się dzielnica osób o dochodach niższych. Nie powstała tu żadna strefa biedy. Wszędzie jest czysto, domy są dobrze utrzymane, nie brakuje sklepów, szkół i przeszkoli, zgrabną sylwetką wyróżnia się w pełni wymiarowy stadion sportowy.

Ostatnią część stolicy Idealnii stanowi obszar przemysłowy. Dominuje nad nim różnobarwny, zbudowany w fantazyjnym kształcie zakład produkcyjny: wytwórnia pudełek firmy Marvelous Boxes. Idealnijskie pudełka znalazły odbiorców w wielu krajach i dostarczają krajowi wielu dewiz. Nie ma w tym niczego dziwnego, każdy człowiek potrzebuje co najmniej kilku pudełek: na narzędzia, do kuchni, na dokumenty i ważne papiery, na zabawki, na lekarstwa, na pendrive'y, na bizuterię, na wycinki prasowe. Potrzebuje pudeł dużych i małych, zrobionych z tworzywa sztucznego lub z tektury, zamykanych na klucz mechaniczny, magnetyczny, cyfrowy lub pozbawionych wieczka. Marvelous Boxes, duma narodu idealijskiego, dostarcza pudełka o najróżniejszych rozmiarach, przeznaczeniu, kolorach i fakturze. 
Firma stanowi spółkę akcyjną, której akcjonariuszami są wszyscy obywatele. Noworodki otrzymują jedną akcję, deponowaną u rodziców. Naturalnie rozkład własności nie jest równomierny, między innymi dzięki możliwości handlu akcjami. Ostatniej z nich Idealnijczyk nie miał prawa sprzedać nikomu.

Granica stolicy tego niedużego kraju wyznacza początek terenów wiejskich. W Idealnii są dwie duze wsie i niemała liczba słabo zaludnionych, czasem schowanych w lesie, osad. W niektórych z nich mieszkają ludzie pracujący $\mathrm{w}$ stolicy, codziennie dojeżdżają do miasta prezydent i kierownicy przedsiębiorstw, banków i centralnych instytucji.

Rolnictwo idealnijskie stoi na dobrym poziomie. Uprawia się zboże i warzywa, częściowo na eksport. Dwie winnice dostarczają surowca do produkcji win. Zdaniem znawców miejscowy terroir jest niezwykle obiecujący. Istnieje niewielka hodowla zwierząt. Rybołówstwo morskie i akwakultura w zbiornikach słodko- i słonowodnych dostarczają ryb i mięczaków, znowu możliwy był pewien eksport towarów. Rolnikom i rybakom wiedzie się dobrze, należą do dochodowej elity kraju.

Ostatnim, co nie znaczy, że mało ważnym, odcinkiem życia gospodarczego Idealnii jest turystyka. Piękna, piaszczysta i długa plaża zachęca do opalania się, pływania, surfingu i spacerów. Kilka hoteli i pensjonatów w nadmorskiej, niedużej, a urokliwej miejscowości zapewnia w nocy wygodny wypoczynek, a w dzień nadmorskie rozrywki i świetne wyżywienie.

Nie trzeba dużo czasu, by Idealnię przejechać, a nawet przejść, wzdłuż i wszerz. Coś atrakcyjnego dla siebie znajdą tu amatorzy uroków morza i krajobrazu wiejskiego, szukający turystycznego gwaru i zakochani w ciszy, jaką daje izolacja od cywilizacji. Przemieszczając się po wyspie, wszędzie spotyka się ludzi pogodnych, życzliwych i otwartych na przyjezdnych. Idealczycy mają w sobie wiele uroku i wyglądają na ludzi szczęśliwych. Wszystko jest przyjazne mieszkańcom i gościom, na Idealnii każdy czuje się dobrze. W szczególności nie widzi się wysokich płotów, drutów kolczastych i wszędobylskich kamer monitorujących. Pracownicy 
ochrony pojawiają się rzadko, żaden obiekt nie robi wrażenia oblężonej twierdzy. Jedynie mała część wyspy odległa od stolicy i miejscowości nadmorskiej została zamknięta tworząc poligon dla żandarmów i policjantów. Trudno zresztą, by podczas szkolenia wolno im było przeszkadzać.

* * *

Andrzej dotarł na Idealnię promem. Wysiadł razem z dużą grupą wczasowiczów kierujących się do hoteli i pensjonatów. Prawdopodobnie był jedynym przybyszem, który miał przed sobą do wykonania zadanie służbowe.

Szybko opuścił port i wsiadł do taksówki. Po dwudziestu minutach zatrzymał się przed hotelem „Sunflower” w miejscowości nadmorskiej. Miał tam zarezerwowany pokój. Jak się okazało duży, wygodny i z widokiem na morze.

Przed przyjazdem Andrzej zapoznał się $\mathrm{z}$ topografią Idealnii, wiedział więc, że ma do pokonania ledwie sześć kilometrów. Podróż taksówką, która nie okazała się tania, była dużo droższa niż autobusem, ale z pewnością znacznie wygodniejsza. Do pierwszego umówionego spotkania miał cztery godziny czasu, wystarczająco dużo, by odświeżyć się po podróży i rozejrzeć się w nowym miejscu.

Wziął prysznic, wykąpał się w morzu, przebrał się i zaszedł na kawę do hotelowej restauracji. Obiad planował zjeść po odbyciu rozmów. Kawa, ani trochę różna od tej, jaką pił codziennie na kontynencie, pomogła mu przypomnieć sobie, o co ma pytać swoich rozmówców. Nie odczuwał żadnej tremy.

Punktualnie dotarł do siedziby prezydenta, który nie kazał czekać na siebie ani minuty. Był człowiekiem o pogodnym usposobieniu, wysokim, ubranym w świetnie skrojony garnitur, w żaden sposób nietraktującym gościa z góry. Po krótkiej wymianie grzeczności i wyrażeniu przez Andrzeja podziękowania na możliwość odbycia spotkania panowie przeszli do konkretów. Prezydent opisywał swój kraj jako dobrze zorga- 
nizowany, stabilny, bogaty, pozbawiony ubóstwa, rządzony umiejętnie i sprawiedliwie. Andrzej interesował się najbardziej, w jego przypadku było to najzupełniej zrozumiałe, sprawami gospodarczymi, ten temat nie stanowił jednak silnej strony prezydenta. Dużo więcej niż o budżecie państwa, systemie finansowym lub strukturze $\mathrm{PKB}$ miał do powiedzenia o zaletach plaży i zmieniającym się, zależnie od pory dnia, kolorze morza. Cieszył się, że jego gość zamieszkał blisko morskiego brzegu, co pozwoli mu doświadczyć niezapomnianych uroków królestwa Neptuna stykającego się z Idealnią.

W planie Andrzeja była wizyta następna, u ministra spraw gospodarczych. Urzędował on w sąsiednim budynku, równie dużym, co gmach prezydenta. Zważywszy na większą liczbę pracowników robił on wrażenie nieco ciasnego. Andrzej przekonał się szybko, że biuro ministra spraw gospodarczych zajmowało połowę budynku, biuro ministra spraw socjalnych jedną czwartą, dział ministra spraw zagranicznych trzy ósme, a przestrzeń ministra spraw wewnętrznych jedną ósmą. Oddział spraw zagranicznych tonął w marmurach i dywanach, spraw socjalnych $\mathrm{w}$ boazerii, ściany oddziału spraw gospodarczych były kolorowe niczym sławne idealnijskie pudełka, a ściany sekcji spraw wewnętrznych zakrywały mundury żandarmów, policjantów, strażaków, pracowników sanepidu, strażników granicznych i strażników więziennych.

Minister spraw gospodarczych był człowiekiem niskim, średniej tuszy, wesołym oraz, co dało się odczuć od razu, energicznym. Powitalne uprzejmości trwały krócej niż u prezydenta. Andrzej był człowiekiem konkretnym, a więc swój trafił na swego. W spotkaniu uczestniczył dyrektor generalny ministerstwa, również człowiek rzutki i zdecydowany.

Andrzej poprosił najpierw o ogólną ocenę sytuacji gospodarczej, zainteresowanie którą było czymś naturalnym, zważywszy na jego miejsce pracy na kontynencie. Minister opisał strukturę idealnijskiej gospodarki, stan budżetu, politykę pieniężną, bilans płatniczy, wzrost PKB, problemy socjalne i aktualną sytuację przedsiębiorstw. Zaznaczył, że politykę pie- 
niężną prowadzi niezależny bank centralny, ale przy tej okazji opisał jej założenia na rok nadchodzący, zaznaczając, że rada banku tej sprawy jeszcze nie rozstrzygnęła.

Gość ministra zainteresował się efektami wprowadzenia w życie zasady pieniądza suwerennego, która w opinii pomysłodawców miała chronić przed niewypłacalnością banków. Przewidywała, że banki komercyjne będą udzielać kredytu do wysokości posiadanych depozytów, przez co o dynamice podaży pieniądza zacznie w pełni rozstrzygać bank centralny. Dyrektor generalny zwrócił uwagę, że projekt ten powstał na kontynencie, ale został wdrożony w Idealnii, jak zwykle tutaj z dużym powodzeniem. Zapytany o szanse uniknięcia w tych warunkach niewypłacalności banku komercyjnego, minister zwrócił uwagę, że ryzyko takie dalej istnieje, ale gdzie jak gdzie, na Idealnii jest znikome. Tutaj ostrożna polityka gospodarcza jest regułą żelazną, dzięki czemu kraj rozwija się pomyślnie.

W miarę upływu czasu rozmowa stawała się bardziej swobodna. Minister chwalił zalety miejscowych pudełek, plaży, przetworów rybnych, serwetek, które zyskują coraz większe wzięcie na świecie i coraz skuteczniej penetrują globalne rynki, oraz znakomitego lokalnego wina.

Spotkanie dobiegło końca. Andrzej podziękował za wyjaśnienia, wyraził pogląd, że Idealnia jest na świecie niestety mało znana, oraz stwierdził, że jego Biuro będzie w stanie przekazywać bogatszą wiedzę na temat osiągnięć Idealnijczyków.

Minister poprosił dyrektora generalnego, by towarzyszył gościowi do wyjścia. Zaznaczył, że taki jest tutaj zwyczaj w przypadku wizyt osób ważnych.

Żegnając się w drzwiach budynku, Andrzej ponownie podziękował za wizytę i informacje. Uścisnął dłoń dyrektora generalnego. W tym momencie poczuł w ręce jakiś drobny przedmiot. Spojrzał uważnie na dyrektora, jego twarz wyrażała jedynie uwagę i grzeczność skierowane w stronę przybysza z kontynentu. Panowie z powagą kiwnęli do siebie głowami. 
W bramie budynku poza dzielnicą rządową Andrzej dyskretnie spojrzał na przekazany mu przedmiot. Karteczka zawierała krótką treść: „Dzisiaj 20, tawerna Złota Kotwica”.

$$
* * *
$$

Była godzina trzecia po południu, do wieczora było jeszcze daleko. Andrzej postanowił zjeść obiad.

W kantorze wymienił dużą kwotę w euro na tutejsze topy. Kurs wynosił dziewiętnaście euro za jednego topa. Zamierzał płacić gotówką, użycie karty w kraju cywilizowanym, ale nienależącym do międzynarodowych organizacji i ugrupowań, mogło oznaczać przeliczanie należności przez kursy wyjątkowo niekorzystne.

„Najpierw obiad” - pomyślał. - „A potem zorientuję się, jakie tu są ceny. Ile kosztuje dobry obiad, krawat, para butów, gazeta, kilogram kiełbasy, para skarpetek? Jakie są relacje cen?”

Spacerem powoli doszedł do Wielkiej Osi i wybrał dobrą, chociaż niewyglądającą na rekordowo drogą, restaurację „Olymp”. Zamówił zupę cebulową oraz smażonego tososia z pomidorami i ryżem. Do tego wypił duży kieliszek najlepszego idealnijskiego wina. $\mathrm{Na}$ deser zjadł kajmakowe teramisu, który uzupełniła filiżanka czarnej kawy.

Obiad okazał się znakomity. Cena: dwadzieścia cztery topy, Andrzej zapłacił dwadzieścia pięć. Czyli jest tu strasznie drogo.

Wrócił do hotelu, przebrał się i wrócił do stolicy. Aby poznać lokalny handel, zaszedł do kilku małych sklepików, a na koniec dotarł do niedużego domu towarowego oferującego produkty niemal dowolnego rodzaju. Wszędzie było drogo, ale też nigdzie nie było pusto. Ludzie robili zakupy, nie bali się wysokich cen.

$\mathrm{Na}$ wystawie ekskluzywnego sklepu zobaczył zegarek marki Patek Philippe Nautilus. W'śród szwajcarskich zegarków zajmuje on pozycję numer jeden. Do towaru dołączona była cena: dwa i pół tysiąca topów. Andrzej bardzo się nią zdziwil, była to kwota ogromna. $\mathrm{Na}$ kontynencie 
taki sam zegarek można było kupić znacznie taniej. Pomyślał, że żyją tu ludzie dostatecznie bogaci, by pozwolić sobie, bez wyjeżdżania z kraju, na taki luksus i za takie pieniądze.

Do wieczora Andrzej zebrał jeszcze więcej obserwacji o miejscowych cenach, handlu, usługach, ruchu ulicznym, architekturze, sztuce ulicznej oraz umiejętnościach policjantów patrolujących stolicę kraju. Nadszedł wieczór i zrobiło się nieco ciemno. Tawerna „Złota Kotwica” znajdowała się w dzielnicy portowej. $Z$ zewnątrz prezentowała się schludnie, wewnątrz też było czysto. Wiele stolików zajęli goście, głównie mężczyźni. Raczyli się winem lub piwem, jeżeli byli głodni pałaszowali fish and chips, tawerna uzupełniała konsumpcję o bezpłatną muzykę w wykonaniu grupy instrumentalistów i czarnowłosej śpiewaczki o atrakcyjnym wyglądzie.

Była godzina dwudziesta. Dyrektor generalny z ministerstwa już czekał. Miał na sobie kolorową flanelową koszulę i żeglarską czapkę na głowie, popijał wino. Andrzej również zamówił wino. Uważnie rozejrzał się po sali. Nie była to żadna portowa mordownia. Wszystko wskazywało, że było tu bezpiecznie.

- Jak się panu u nas podoba? - zapytał dyrektor generalny. - Czy miał pan czas rozejrzeć się po stolicy?

- Tak, zajęło mi to kilka godzin. Wrażenia są bardzo korzystne, chociaż muszę powiedzieć, że jest tu drogo. Przed południem wykąpałem się w morzu - odpowiedział uprzejmie Andrzej.

- Jak pan ocenia hotel? Czy jest wygodny?

- Bez wątpienia tak.

- A jak długo zamierza pan tu pozostać?

- Wyjeżdżam pojutrze w godzinach rannych.

- Proponuję jeszcze raz skorzystać z naszej plaży. Jeżeli ma pan ochotę zobaczyć od środka fabrykę pudełek, zaaranżuję odpowiednie spotkanie - zaoferował dyrektor.

- Z wielką chęcią. To byłoby niezwykle ciekawe. Chcę po powrocie cós napisać o Idealnii, która ciągle pozostaje u nas mało znana - Andrzej ucieszył się z takiej propozycji. 
- W takim razie może przyjedzie po pana do hotelu ktoś z Marvelous Boxes po południu. Szczegóły przekażę jeszcze dzisiaj do hotelu.

- Będę bardzo zobowiązany.

Dyrektor generalny przerwał rozmowę i poważnie spojrzał na Andrzeja. Stało się jasne, że chce zmienić temat rozmowy.

- Pan wie, z czego nasz kraj żyje? - zapytał ściszonym głosem. Przecież nie tylko z pudełek.

- Zapewne. Chociaż pudełka robicie naprawdę świetne. Mam jedno w domu.

- Sprzedajemy metale ziem rzadkich - dyrektor nadal mówił cicho. Część wyspy zajmuje poligon i równocześnie stanowisko górnicze. Andrzej dobrze wiedział, czym są metale ziem rzadkich. Jest to grupa siedemnastu pierwiastków chemicznych: cer, dysproz, erb, europ, gadolin, holm, iterb, itr, lantan, lutet, neodym, prazeodym, promet, samar, skand, terb i tul. Wbrew nazwie dwa pierwiastki ziem rzadkich, cer i itr, występują w przyrodzie dużo częściej niż niektóre pierwiastki spoza tej grupy. Znaczenie ekonomiczne ich wszystkich jest ogromne. Są niezbędne - czasem w małych ilościach - do produkcji zaawansowanych urządzeń technicznych, na przykład baterï słonecznych, laserów, wzmacniaczy optycznych, urządzeń rentgenowskich. Nie trzeba ich dużo, ale bez nich produkcja staje.

- Przecież na światowym rynku metali ziem rzadkich dominują Chiny - stwierdził Andrzej. - Bardzo niechętnie je eksportują, bo chcą zatrzymać u siebie produkcję wielu urządzeń. Nie wchodzicie im $\mathrm{w}$ paradę?

- Nie! W stosunku do nich sprzedajemy małe ilości. To nie zaburza im rynku, a my mamy swoich wybranych odbiorców, którzy u nas kupują trochę taniej niż gdzie indziej. Jesteśmy mali i dlatego nikt nie traktuje nas jako kłopot.

Dyrektor spojrzał uważnie na Andrzeja i dyskretnie rozejrzał się po tawernie. Goście interesowali się zawartością swych talerzy i szklanek, orkiestra grała, śpiewaczka stała odwrócona do nich plecami. 
- Tu ma pan numery kont w zagranicznych bankach. Niech pan się przyjrzy przepływom pieniądza, a zrozumie skąd ta zamożność, efektywność i sprawiedliwość.

- Każe mi pan oglądać rachunki bankowe - powiedział z dużym spokojem Andrzej. - To nie jest możliwe. Istnieje tajemnica bankowa. Wypowiadając ostatnie dwa słowa wykonał wieloznaczny ruch ręką. Ale kartkę papieru schował.

- Dlaczego pan o tym wszystkim mi mówi? - zapytał po chwili.

- Minister mi podpadł. Dobrze byłoby wreszcie się go pozbyć.

Andrzej kiwnął głową i nic nie powiedział. Pomyślał tylko „Pewnie chcesz, żebym u siebie coś opublikował, a wtedy minister spraw gospodarczych wyleci ze stanowiska".

- Dużo mi pan pomógł. Mam dzięki panu szerszy obraz zjawisk. Dziękuję za spotkanie. A firmę Marvelous Boxes chętnie odwiedzę. Mężczyźni podali sobie ręce i powoli, najpierw jeden, potem drugi, opuścili tawernę. Na dworze było już całkiem ciemno.

$$
* * *
$$

Andrzej wysiadł z promu, na brzegu czekał na niego Leszek, kierownik Biura Ocen Ekonomicznych. Panowie przyjaźnie przywitali się. Leszek zaproponował kawę lub piwo, by bez zwłoki omówić zadania czekające na wysłannika wracającego na kontynent. Andrzej zdecydował się na dużą dobrą kawę. Zrezygnował ze wspólnego śniadania, zjadł je wcześniej za ostatnie topy na promie.

Mężczyźni wybrali kawiarnię „Blanc et Noir”. Stała obok wysokiego masztu z flagą w kolorach białym, niebieskim i zielonym. Były to barwy inne niż na fladze Idealnii. Państwo na kontynencie nie gwarantowało swoim obywatelom zamożności, efektywności i sprawiedliwości, jego sztandar symbolizował wartości skromniejsze: pokój, kreatywność i nadzieję. - Potrzebuje sprawozdania z twojej podróży, ale to nie wszystko Leszek szybko przystąpił do konkretów. 
- Czego więcej ci potrzeba? - zapytał Andrzej.

- Podczas twojej nieobecności pojawiły się dwa fakty. Musimy je skomentować. Zbliżają się wybory i wygłasza się wiekopomne obietnice. Podlasiński proponuje szybką budowę największego na świecie ośrodka lotów kosmicznych. Ośrodki amerykański i rosyjski takie nowe już nie są, Podlasiński więc twierdzi, że mamy szansę zaistniéc na skalę globalną. Jeżeli powstanie ośrodek wielki, znajdą się chętni latać w kosmos i na Marsa. Sukces finansowy murowany.

- Tak rozumuje Podlasiński? - zadał pytanie Andrzej. - A za czyje i jak duże pieniądze chce pobić rekord świata?

- Jeszcze nie powiedział. On zawsze chce rzeczy wielkich. Problem większy, przynajmniej dla ciebie, będziesz miał z Juzweckim.

- A ten co namalował? - Andrzej zaczął drapać się po głowie.

- Chce wprowadzić pieniądz suwerenny. Mówi, że skoro sprawdza się na Idealnii, musimy ją naśladować. Biuro powinno wypowiedzieć się w tej sprawie - odparł Leszek.

- Przecież w naszych warunkach pieniądz suwerenny to kompletna bzdura. Ludzie nie wiedzą, jak ten suwerenny pieniądz się je, więc może ktoś to kupi. Ale to czyste szaleństwo! Na Idealnii to funkcjonuje, bo są tam specyficzne warunki. Rozgryzłem ich. To jest gospodarka pałacowo-surowcowa. Oni wcale nie żyją z tych pięknych pudełek i piaszczystej plaży, o których ciągle mówią. Mają zasoby metali ziem rzadkich, które sprzedają po cichu i po cenach lekko obniżonych tak, by łatwo znaleźć nabywcę i nikomu się nie narazić. Nie należą do organizacji międzynarodowych, informacje gospodarcze udostępniają wybiórczo. Wystarcza im, by świetnie żyć. Idealnia liczy raptem trzynaście tysięcy mieszkańców, dlatego metali nie trzeba sprzedawać bardzo dużo. Trudno to wypatrzeć osobom z zewnątrz, Idealijczycy potrafią się tajniaczyć. Zarobionych pieniędzy starcza im dla wszystkich. Nawet najbiedniejszy dostaje sporą kość do zgryzienia.

Andrzej na chwilę przerwał wypowiedź i upił duży łyk kawy. 
- Gospodarka pałacowo-surowcowa powiadasz - Leszek powoli wypowiadał słowa. - Pasożytująca na reszcie świata.

- Za mocne słowa. Sprytnie się ustawili i żyją dzięki reszcie świata. Tak trzeba powiedzieć. Miniaturowa Atlantyda, która nikomu nie szkodzi i nikt się nią nie przejmuje. Jest tam zamożność, a o efektywność i sprawiedliwość się nie martwią. Zawsze znajdzie się pokaźna garść okruchów, by zrobić politykę społeczną.

Leszek słuchał z wyraźną uwagą. Widać było, że analizuje i rejestruje każde wypowiedziane słowo.

- Mam numery ich kont bankowych u nas, na kontynencie - ciągnął dalej Andrzej. - To są, jak dla nich, ogromne sumy. Forsa płynie ostro. Dobrze byłoby poznać, jak krąży za granicą ich pieniądz, który oni u siebie zamieniają na tak zwany pieniądz suwerenny.

Ostatnie zdanie wygłosił tonem drwiącym.

- Słyszę, że dużo się dowiedziałeś. Same ciekawe rzeczy- skomentował Leszek. - Czeka cię teraz robota. $\mathrm{Na}$ potrzeby publikacji trzeba zrobić oceny mrzonek Podlasińskiego i Juzweckiego. No i opis tego, co zobaczyłeś na Idealnii. Wszystko prędko, Alojzy na mnie naciska.

- Rozumiem - Andrzej pokiwał głową z lekkim uśmiechem. - Nie dasz mi odpocząć.

- Jest jeszcze jeden temat dla ciebie. Trzeba zrobić ocenę nowych warunków wchodzenia przedsiębiorstw na giełdę. Coś chcą zliberalizować, coś zaostrzyć.

Słysząc to, Andrzej poczuł się w swym żywiole.

- To będzie zadanie trudniejsze - zauważył.

- Tak. I bardziej poważne - dodał prędko Leszek przyglądając się reakcji kolegi.

- Za tym też kryje się Alojzy? - zapytał Andrzej.

Leszek wysunął nieco dolną szczękę do przodu i zrobił minę potwierdzającą.

- Tak! 


\section{Paweł Kozłowski}

\section{Zawsze}

W Jczoraj, czyli w czwartek. Trzy lata temu, a nawet wcześniej W spotkaliśmy się u podstawy. Postanowiliśmy zdobyć szczyt. Był u góry. Andrzej zaproponował drogę. Najkrótszą. Pionową. Ucieszyłem się i trochę zainteresowałem. Kiedyś już spadłem, co zrobiło na mnie pewne wrażenie. Zapytałem, czy są liny. Powiedział, że tak. Nie wziąłem rękawiczek. Zaniedbałem przygotowania. Na dole jest ciepło. Dlatego. Zdjąłem więc skarpetki i włożyłem na dłonie. Zauważyłem, że stopy zrobiły mi się bose. Włożyłem więc jedną skarpetkę na dól, a druga na górę. Co dało połowę tu i połowę tam. Kiedyś Andrzej mi wyjaśnił, że dwie połowy stanowią całość. Nie mogłem uwierzyć. Doświadczenie uczy czegoś innego. Teraz zaryzykowałem. Jeżeli jest tak, jak on twierdzi, to będę miał dwie całości. Po zaokrągleniu.

Staliśmy. Nacisnął jakiśs guzik. Z prawej strony. Zapalił się na czerwono. Przygotowałem się na atak. Przed nami otworzyły się niewielkie wrota. Przesmyk. Powstało zamieszanie. Nie uzgodniliśmy uprzednio, kto będzie z przodu. Zaproponowałem siebie. Jestem nizzszy, nieznacznie, mniej niż o metr. Jeden. W przybliżeniu. I wystarczająco zasłaniam widok. Przystał na taką kolejność. Dałem mu plecak. On swój nosi 
z przodu, a więc z tyłu ma miejsce. Wypełniłem je. Znowu coś nacisnął. Zamknąłem oczy. Zapytałem ponownie, gdzie są liny. Nic nie powiedział. Domyśliłem się, że będą potrzebne w drodze powrotnej. W dół. Po chwili zabrakło mi powietrza. Atak choroby wysokościowej. Miewam ją pod wodą, zwłaszcza w wannie. Stanęliśmy. Zobaczyłem na pionowej ścianie cyfrę cztery. Oznaczał stopień trudności. Na mnie wrażenie robi dopiero dziewiątka. Wkrótce byliśmy na szczycie. Góry dają spokój. Ta dała. Nie wiało. Helikopter nie latał. Obok przemknęła kobieta, lat około 109. Z połową. Łączyła doświadczenie z siłą utrwaloną. Zorientowałem się, że jest tu już od jakiegoś czasu. Dałem jej chorąiewkę. Razem weszliśmy do pomieszczenia bazy. Dokonaliśmy tego od razu, bez klimatyzacji. Nie działała. Posłużyliśmy się stylem taternicko-alpejskim, w którym zdobywa się Kilimandżaro.

Rzuciłem okiem na planszę obok drzwi. Informowała, że będą instrumenty po coś chodzące. Zrozumiałem to w lot. Kiedyś byłem w filharmonii. Zabrała mnie koleżanka, która miała nową sukienkę i chciała pokazać. Pokazała. Wolę, jak sukienka jest obok i koleżanka obok. Oprócz niej widziałem tam trąby. Dwie. Takie same, jakie mają strażacy - gdy idą, to w nie dmuchają W każdym razie wiem, co to są instrumenty i po co. Występują także u dentystki. Lubię u niej bywać. Kiedyś chciała jakiś instrument i patrzyła mi w oczy. Zastanawiałem się, co robić dalej. Na razie leżałem. Długo, bo się speszyłem. Szybciej koleżanka dała jej jakiśs drut. Dosyć srebrny. Włożyła mi w usta. Za karę. Odgryzłem go w połowie i połknąłem.

Teraz patrzyłem jeszcze raz na ogłoszenie. Było też w nim napisane, że to konferencja. Przed laty byłem na czymś takim. Ktoś coś mówi, a reszta siedzi i czeka. Niecierpliwie. Bardziej wprawni śpią. Za to dostaje się wyższe stopnie. Później impreza się kończy i wszyscy idą jeść. Podali wtedy gołąbki oraz ciastka. Też kawę. Następnie ponownie wszyscy usiedli. Odpoczywali. Jeden mówił, ale nowy, bo tamten się zmęczył. Po kilkunastu minutach widzowie wychodzili. Stopniowo, ten, kto poczuł się na siłach, wstawał pierwszy. 
Byliśmy w środku. Kolega zajął lewe skrzydło, ja prawe. Czekaliśmy na herbatę lub kakao i obwarzanki. $\mathrm{Na}$ razie siedzieliśmy. Krzesła, a może fotele byly pod nami. Nie skrzypiały, bo na konferencjach nie wolno. Wysłałem mu kartkę, w postaci samolotu. Odrzutowego, żeby było szybciej. Złapał i przeczytał. Samolot miał zagadkę, czyli rebus. Rysunek przedstawiał wysoką wieżę z zegarem. Budowla ceglana. $Z$ boku dwie litery, jedna nad drugą. Chciałem, żeby mi wyjaśnił, dlaczego ten rebus jest śmieszny. Rozwiązał natychmiast. Po niemal dwóch godzinach. Powiedział głośno, o co chodzi. Wskazał, że jestem autorem. Wtedy wszyscy wstali, od razu. Był najwyższy czas na coś. Poszliśmy na kawę. Inni się rozglądali i czegoś szukali. Andrzej skorzystał z okazji i opowiedział mi historię. O krokodylu w cyrku. Ktoś mu włożył rękę do paszczy, następnie drugą ręką uderzył go w głowę i tę pierwszą wyjął! Zapytałem, po co wyjął. Nie odpowiedział. Człowiek w cyrku obie ręce miał całe. Następne próby były podobne. Chwycilem sens momentalnie. Ja miałem obie ręce całe i słuchaczka, która stała obok, również. Wynika z tego, że nie trzeba krokodyla, żeby było przyjemnie. Andrzej zawsze opowiada śmieszne dowcipy. Oraz mądre.

Instrumenty zakończyły występ i znaleźliśmy się w szatni. Urocze miejsce z lustrem. Umówiliśmy się na spotkanie następnego dnia. $\mathrm{Na}$ picie herbaty i wymianę myśli. Miejsce wybrał kolega. On przyzwyczaił się do różnorodności i dlatego zawsze wychodzi mu to samo. Kawiarnia była bułgarska, utrzymana w stylu rosyjsko-hiszpańskim. Zamówiliśmy wino węgierskie, kiedyśs z takim stykałem się w pociągu. Lubiłem jeździć. Zaczęliśmy omawiać sprawy społeczne. Kolega jest humanistą prawdziwym. Także głębokim. Skoncentrowaliśmy się na połowie zbiorowości, wyszło, że na kobietach. Operowaliśmy zdaniami nierozwiniętymi. W trzecim przeszliśmy do zagadnienia kluczowego. Istoty najbližszej życia mężczyzny. Psa. Piliśmy nadal herbatę, żeby nam nie zaschło. W szklankach. Były dwie i stały na kolumnach. Każda z nich miała bazę. W sumie wychodzi sześć. Przy siódmej butelce zajęliśmy się losem jednego. Andrzej u niego mieszka. Wychodzą razem się przewietrzyć 
i rozejrzeć. Kolega ma swój kąt oraz miewa odrębne pomieszczenie. Czasami, jak zamknie drzwi, których nie może zamykać. Kiedyś zasugerowałem mu, żeby razem chodzili na trening kulturalno-gimnastyczny. Upadło, bo pies się nie zgodził. Było za daleko, a on jeździ tylko samochodami sportowym, kabrioletami. Kolega nie ma, ale zbiera pieniądze. $\mathrm{Na}$ razie klapa. Samolotem może, lecz tam nie zrobili jeszcze lotniska. Już zaplanowali, sołtys załatwił. Związek kolegi i psa staje się kłopotliwy zimą. Pies ma cztery nogi i w związku z tym są one krótkie. Gdy leży śnieg, to pies zamarza. Od dołu. Wtedy drugiemu, czyli Andrzejowi, robi się gorąco. Od góry. $Z$ przejęcia. Starają się więc nie wychodzić. Spędzają czas w domu i razem śpiewają.

Bohaterski pies ma inteligencję oraz urodę. Ta druga jest uchwytna, ta pierwsza nie. Jedno i drugie działa mobilizująco na jego opiekuńczego partnera. Stara się i dużo pracuje. Nad sobą. Kilka lat temu zaczął czytać książkę. Jest alegoryczna, bo odnosi się do czegó́ innego niz z pozoru. Przedstawia człowieka, istotę tylko dwunożną. Osiadł na bezludnej wyspie. Na skutek życiowego rozbicia, do którego doszło na morzu. Każdy wie, że w gruncie rzeczy, jakiś autor, podobno angielski, ukazał psa Andrzeja. Jego dramatyczny los. Rozbitka lądowego. Znalazł się gorzej niż osamotniony. Bo w obcym, na ogół wrogim, środowisku. Andrzej chce mu ulżyć, bo go rozumie. Wieczorem opowiada mu dowcipy. Wtedy pies się rozluźnia i ziewa. Siedzi sobie w fotelu, który jest wygodny i rodowy. Nie ma kominka, co niepokoi i tworzy pustkę. W mieszkaniu są książki. Przeszkadzają. Poza jedną, która leży pod nogą stołu. Utrzymuje stabilność całości. Pozostałe trzy stoją w regale i zajmują miejsce butom oraz zdjęciom. Andrzej zbiera fotografie, zwłaszcza z czasów młodzieńczych. $\mathrm{Ma}$ ich coraz więcej. Trzecie ziewnięcie jest sygnałem do rozpoczęcia części lirycznej. Pan zmienia tiszert z zielonego na czarny, wieczorny. Czyta wiersz. Własne słowa, rymy wspólne. Pies zasypia. Szybko. Śni mu się nowy świat i lokal z cygarami. Można na wynos lub wypalić na miejscu. Raz na jedenaście dni wysyła tam opiekuna po zakupy. Przebiera czterema łapami i marzy, że kolega mu przynosi łiskacz. Specjalny środek 
odżywczy. Bardzo wskazany. Dobrze wiąże się z fotelem i się nie psuje. Panuje cisza, bo pies lubi skupienie. Pan niekiedy go rozprasza.

Rozmawialiśmy ciągle, gdy nie było przerwy. Zapragnęliśmy coś zjeść. Andrzej zamówił kotlet schabowy i golonkę. $Z$ soi i pietruszki. Bardzo dba o linię. Niczym jaguar, szczególnie E. Ja zdecydowałem się na to samo, tylko odwrotnie zjadłem. Pietruszka z golonki była bardzo delikatna. Soja mniej, miała za kruchą panierką. Skoordynowanymi ruchami zmierzaliśmy do końca. Na ulicy zgasili latarnie, włączyli centralne oświetlenie. Górne. Przemknął tramwaj. Przejechała polewaczka, która miała z przodu pług. Andrzej zamówił jeszcze coś dla podopiecznego. W lokalu nie było kawioru irańskiego, więc wziął rosyjski. Przepakował $\mathrm{w}$ słoik z napisem perskim. Pies na inne nie patrzy. Wybrał też pasztet z truflami. Wyrób z gęsi w przeciwieństwie do trufli. Dobrał szampana. Jakiś francuski. Dla siebie wziął wodę. Niegazowaną. Pies nie lubi, jak ona ma bąbelki, bo podejrzewa podróbkę bądź naśladownictwo. Andrzej włożył wszystko do kieszeni i skierowaliśmy się do wyjścia. Nie mogliśmy trafić, zwęziły się ostatnio. W końcu wyjście nam wyszło.

Każdy poszedł w swoją stronę. Po czterech krokach okazało się, że w tą samą. Zadzwoniłem. Andrzej też. Mój numer był zajęty. Zawsze tak jest, gdy dzwonię do siebie. Aparat ma jakieś uszkodzenie. Jego też nie odbierał. Uzgodniliśmy bezpośrednio, że udamy się do biblioteki. Odpocząć. Nie wiedziałem, gdzie coś takiego jest w naszym mieście. Słyszałem, że kiedyśs taką zbudowali na południu. Zdałem się na przyjaciela. On wiedział. Podnieśliśmy ręce, w sumie dwie. Stanęła taksówka, która była limuzyną. Zawiozła nas do pałacu. Toczyła się konferencja, z góry na dół. Bez instrumentów. Popatrzyłem wymownie, żeby nic nie mówić. Wtedy on skorzystał z okazji. Przeszedł do nauki i oznajmił: jak się nie ma, to trzeba oszczędzać. Ja polemicznie rozwinąłem: jak się nie ma, to należy wydawać. Więcej. Bo wtedy jest przyjemnie bardziej. AS podsumował: pies jest najważniejszy. W prowadziłem precyzję i ścisłość: zawsze.

Po zachodzie, przed wschodem Stońce 


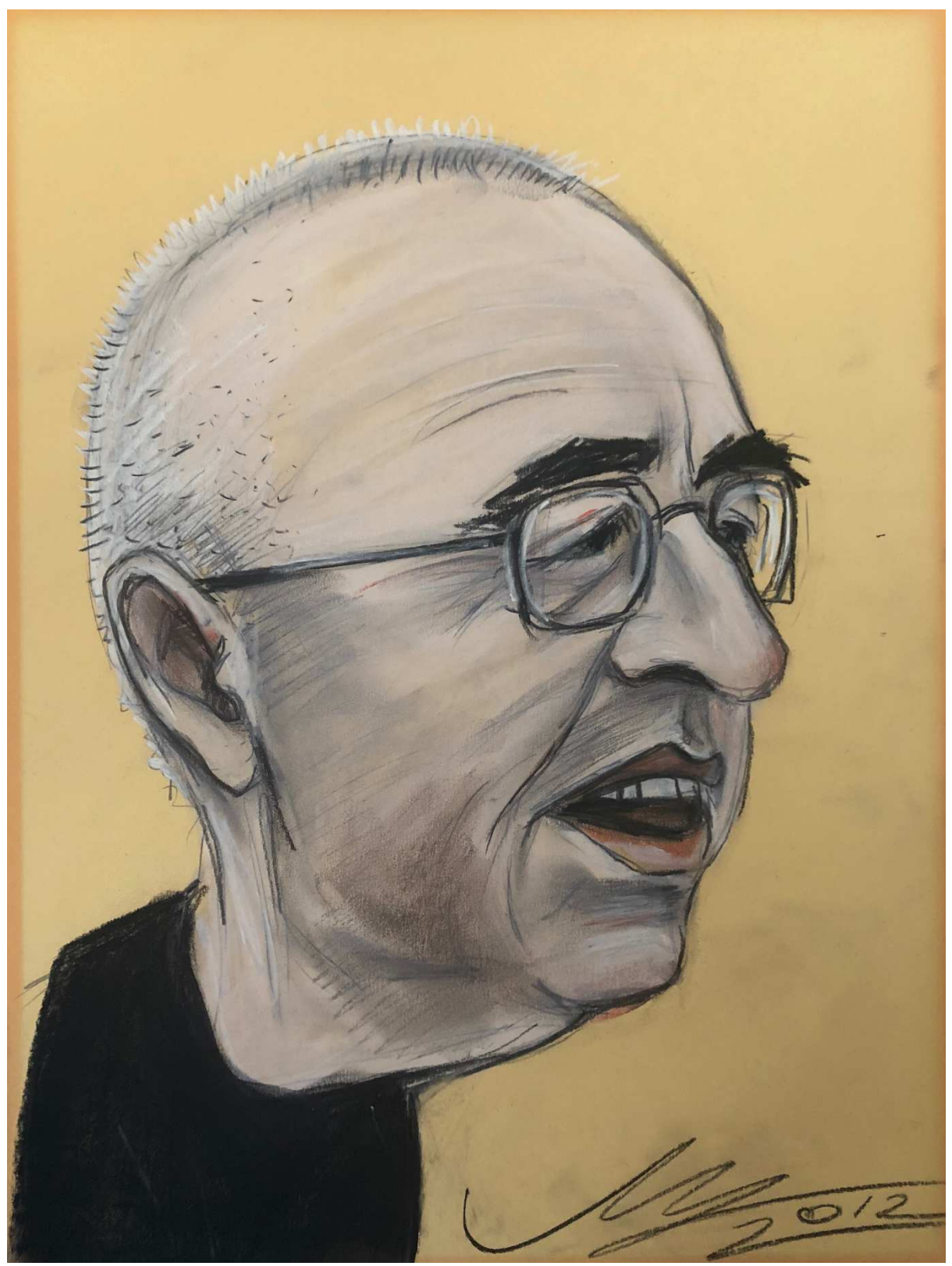




\section{Andrzej w świetle reflektorów}





\section{Marek Monkiewicz}

\section{Andrzej \\ - z żartobliwym dystansem do świata}

7 Profesorem Sopoćko (odtąd: z Andrzejem - ponieważ Pan Prodystans" i poprosił mnie, żebym zwracał się do niego po imieniu) znamy się od dość dawna. Powiedziałbym nieprawdę, gdybym stwierdzil, że jest to znajomość bardzo głęboka, niemniej jednak niejednokrotnie miałem sposobność spotkać się z Andrzejem przy różnych okazjach.

$\mathrm{Na}$ płaszczyźnie naukowej nasze kontakty były najbardziej bliskie $\mathrm{w}$ trakcie pisania przeze mnie rozprawy habilitacyjnej. Co ciekawe, nie widywaliśmy się aż tak często, natomiast nasze dwustronne spotkania pozwalały mi nabrać pewności, iz efekty moich wysiłków, chociaż wymagają pewnych korekt, to jednak idą we właściwym kierunku. Andrzej przy tym nie występował w roli mentora, wskazującego, że ma być „tak i tak", lecz raczej traktował mnie po partnersku, nie dając mi odczuć, że jest starszy, bardziej doświadczony i ma większą wiedzę. Obdarzył mnie zaufaniem, za co mu jestem bardzo wdzięczny. Nawiasem mówiąc, warto zwrócić uwagę na szerokie spektrum zainteresowań naukowych 
Andrzeja. Mieści się w nim choćby zarówno tematyka szeroko rozumianej konsumpcji, konsumentów, ale też polityki pieniężnej, finansów publicznych, jak i rynków finansowych, ze szczególnym uwzględnieniem rynku kapitałowego. Oczywiście częściowo jest to pokłosie ciekawej i znaczącej kariery zawodowej także poza murami uczelni, natomiast w dużym stopniu moim zdaniem świadczy to także o swego rodzaju ciekawości poznawczej, która jako naukowca-badacza z charakteru, prowadzi go do zgłębiania kolejnych nurtujących go zjawisk i mechanizmów mających wpływ na złożoną krajową i globalną rzeczywistość społeczno-gospodarczą.

Również na płaszczyźnie służbowej, mogę powiedzieć, że jako mój szef w Zakładzie Ubezpieczeń i Rynków Kapitałowych, pozostawia swoim współpracownikom dużo swobody. Nie jest typem człowieka ustawicznie mobilizującego podległych pracowników do podejmowania rozmaitych aktywności, natomiast chętnie wspiera ich rozwój i ich pomysły, sam niekiedy angażując się osobiście $\mathrm{w}$ realizowane przez nich przedsięwzięcia. W ten schemat dobrze wpisuje się choćby coroczna konferencja ubezpieczeniowa „Obszar Polski Europejskiego Rynku Ubezpieczeń”, zainicjowana dobrych kilka lat temu przez naszego wieloletniego wydziałowego kolegę dr. Stanisława Nowaka. Między innymi dzięki staraniom Andrzeja, od kilku lat na stałe odbywa się ona na Wydziale Zarządzania Uniwersytetu Warszawskiego, zaś on sam regularnie i aktywnie w niej uczestniczy, występując jednocześnie w różnych rolach: jako współorganizator, moderator, prelegent i współautor pokonferencyjnych publikacji książkowych.

W bezpośrednim kontakcie Andrzej sprawia wrażenie człowieka, z którego emanuje niewzruszony spokój. Przy bliższym poznaniu, mogę potwierdzić, że odczucie to pozostaje aktualne. Andrzej faktycznie obdarzony jest niezwykle spokojnym usposobieniem, natomiast takie podejście do życia (jednocześnie poparte ogromnym doświadczeniem życiowym i wiedza) pozwala mu odnosić się do bieżących wyzwań z pewnym żartobliwym „czeskim” dystansem do świata. Wspomniane poczucie 
humoru jest chętnie wykorzystywane przez jego właściciela w rozmowach prywatnych; jest też zgrabnie przemycane w opracowaniach naukowych lub wywiadach. Aby nie być gołosłownym, a jednocześnie dać próbkę możliwości Andrzeja, pozwolę sobie przytoczyć kilka przykładów: "Jeśli jemy tylko biały ryż, to jesteśmy skazani na śmierć, dlatego że nie zawiera on koniecznych substancji odżywczych. Czyli albo zmienimy sposób odżywiania się, albo umrzemy. $Z$ gospodarką jest podobnie, nie może ciągle funkcjonować tak jak teraz i na dłuższą metę nie może być takich relacji między bogatymi a resztą”, „Nie jestem jego zwolennikiem (podatku bankowego - wyjaśnienie moje, MM), ale powiem tak: kiedyś choroby weneryczne leczono rtęcią, która jest pierwiastkiem toksycznym. Jeśli nie ma niczego innego, stosuje się to, co jest (oba przykłady z wywiadu Banki udaja ubogich, „Przegląd”, 13 V 2012), „Wydawałoby się, że pieniądza, jak konia, nie trzeba opisywać. Wszystko wydaje się takie oczywiste. Każdy jakiś pieniądz widział" (na temat, skąd się wziął pieniądz - wyjaśnienie moje, MM), „Gdyby chcieć znaleźć szerszą kategorię pojęciową, w której mieści się pieniądz, niewątpliwie można ją określić jako prawo do korzyści: materialnych (dobra i usługi), duchowych (dostęp do dzieł sztuki), zdrowia (zabiegi lecznicze) itp. Kiedyśs nawet można było dzięki niemu mieć korzyści o charakterze metafizycznym. Odpusty za popełniane grzechy nie kosztowały przesadnie drogo" (oba przykłady z książki Mit pieniądza. Świat realny wobec iluzji polityki pieniężnej autorstwa A. Sopoćko, WN PWN, Warszawa 2015). Korzystając ze sposobności, z okazji okrągłej rocznicy urodzin chciałbym życzyć Andrzejowi utrzymania optymistycznego podejścia do życia oraz zdrowia. Jeśli będzie to pierwsze (co nie jest wykluczone zważywszy na powyższe), to jestem spokojny o to drugie. 


\section{Robert Pietrusiński}

\section{Dla Andrzeja. Dla Artysty}

Waukowiec, wykładowca, autor tekstów, reżyser, aktor. Czyli człowiek

Ciekawe jak Go traktują młodsi i starsi koledzy. Mam nadzieję, że jako reżysera, aktora, autora tekstów. Twórcę trupy kabaretowej WZ UW.

Podziwiam Go za to, że robi coś, co nie jest szablonowe. Poświęca swój czas i energię na organizację przedsięwzięcia, które nie przynosi pieniędzy. Może przynosi coś więcej nizz pieniądze. Przynosi: śmiech, radość, uśmiech, kpinę. Jak wiadomo śmiech przedłuża życie. Andrzeju dziękuję $\mathrm{Ci}$ za to. Jak śpiewał Andrzej w reżyserowanym przez siebie przedstawieniu: „Niech żyje bal, bo to jest najważniejsze”.

Byłem zaszczycony propozycją przystąpienia do kabaretu Andrzeja. Przypomniały mi się czasy moich studiów na Wydziale Prawa i Administracji Uniwersytetu Warszawskiego, gdzie już na pierwszym roku studiów założyliśmy kabaret „Bździungwa” i występowaliśmy w klubie Wydziału Prawa „Pod szafotem”. Dawni aktorzy są dzisiaj znanymi prawnikami. Kabaret trwał dwa lata, potem niestety trzeba było się uczyć. 
Podziwiam Andrzeja i dedykuję Mu ponižszy tekst całkowicie oniryczny' ${ }^{1}$.

Przecież każdy z nas jest samotną indywidualnością.

\section{NIEDŁUGO JUŻ WIECZÓR}

Każdy jest sam pośrodku ziemi,

Przebity słonecznym promieniem:

niedługo już wieczór. ${ }^{2}$

Maria Czubaszek pisała o kabarecie:

Nie lubię, jak się mówi, że polityka to kabaret. Znam świetne kabarety.

Co mnie przekonało, że polityka to nie kabaret. ${ }^{3}$

Znany jest w środowisku naukowym skomercjalizowany system publikacji i punktów, które się za nie uzyskuje. System działa sprawnie. Cała koncepcja jest, jak sądzę, zaczerpnięta z książki Marka Twaina - Przygody Tomka Sawyera 4 . System ten wyglądał następująco. W szkółce niedzielnej, do której uczęszczał Tomek Sawyer za wygłoszenie dwóch wersetów z Biblii otrzymywało się niebieską karteczkę. Dziesięć niebieskich karteczek stanowiło równowartość jednej czerwonej i mogły być na nią wymienione; dziesięć czerwonych równało się jednej żółtej; za dziesięć żółtych dyrektor dawał skromnie oprawioną Biblię. Tomek wymieniał kartki na: miętówki, haczyk do wędki, kule bilardowe i inne drobiazgi. Czatował na chłopców wychodzących do kościoła i przez kwadrans skupował w ten sposób kartki w różnych kolorach. W końcu

1 Oniryczny - taki jak ze snu, mający charakter marzeń sennych, Stownik wspótczesnego języka polskiego, Warszawa 1996, s. 683.

2 S. Quasimodo, Poezje, PIW, Warszawa 1961, s. 21.

3 M. Czubaszek, Kwiatki, Warszawa 2017, s. 9.

4 M. Twain, Przygody Tomka Sawyera, Warszawa 1993, s. 24 i nast. 
zebrał odpowiednią liczbę kartek, które stanowiły możliwość otrzymania Pisma Świętego.

Będąc uczestnikiem wielu konferencji (w tym naukowych), nigdy nie stroniłem od alkoholu, który, jak wiadomo, poprawia znacznie samopoczucie. A czerwone wino, pite z umiarem, obniża zły cholesterol. Może warto zacytować klasyków:

Radości wynikające z picia w żadnym razie nie ograniczają się jedynie do nieokrzesanych żołdaków. W przededniu urodzin Oktawiana Augusta rzymski poeta Horacy wygłasza w liście do Torkwata następującą pochwałę:

Czegoż winko nie sprawi? Rozwiąże języki, Nadzieję wyróżowi, tchórza roześmieli, Prostaczkom w tbach rozjaśni, smutnych rozweseli.

Kogóż mownym obfite nie zrobią kielichy?

Wrzeszczy i dokazuje biedak, przedtem cichy. ${ }^{5}$

Utożsamiam się z tekstem Marii Czubaszek:6

W życiu trzeba mieć miarę.

Żeby nie wypić za mało.

Warto zacytować również znanego satyryka Mariana Załuckiego, którego córka, była żoną naszego kolegi z Wydziału Zarządzania; Leszka Stępniaka.

Tak pisał w 1985 r. Marian Załucki:

\section{Bracia!}

W polityce inny wiatr dziś zawiał!

5 Kwintus Horacjusz Flakkus, Dzieła wszystkie, tom II, Wrocław 1988, s. 274, opisuje Barbara Holland, Radość picia, Warszawa 2009, s. 28.

6 M. Czubaszek, op. cit., s. 34. 
Do innego wiatru

już nas się wystawia... ${ }^{7}$

Przedstawiam tekst z innej epoki. Z kabaretu Bździungwa ${ }^{8}$. Byłem wtedy na studiach magisterskich.

Dynamiczny wzrost zapotrzebowania na magisterium obserwuje się nieomal na całym świecie. Powoduje to oczywiście intensyfikację badań złożonego problemu magistra jako takiego i jego uprawy. Trzeba stwierdzić, że kraj nasz w owych badaniach zajmuje pozycję bardzo wysoką. Dokonano już u nas rejestracji wszystkich istniejących egzemplarzy, a dzięki wykorzystaniu w akcji „magister” dziesiątków tysięcy odpowiednio przeszkolonych pracowników, znamy już dokładnie nasze zasoby i mamy wystarczająco dużo danych do dalszych analiz.

Uprawą magistra (nazwa łacińska: magister wulgaris) zajmują się utworzone w tym celu instytucje. Metoda tradycyjna polega na tym, że kiełkującego magistra przez około 5 lat nawozi się intensywnie i naukowo, a następnie przesadza na inny grunt. Uzyskane w ten sposób młode okazy zwiększają umagistrowienie kraju, a mogą również służyć jako element zdobniczy.

W dużym uproszczeniu można powiedzieć, że metoda druga polega na szczepieniu. Pewne przyczynki można znaleźć w pracach medycznych, poświęconych np. nerwicom lub chorobom wrzodowym układu pokarmowego. Znawcy problemu stwierdzają, że zarówno jedną, jak i drugą metodą udaje się czasami uzyskać piękny okaz magistra na zwykłym pniu.

Magister jest w rzeczywistości mało wymagający. Może $\mathrm{z}$ powodzeniem rozwijać się nawet $\mathrm{w}$ słabo przewietrzanych

7 M. Załucki, Kpiny i kpinki, Wydawnictwo Literackie, Kraków-Wrocław 1985, s. 8.

8 Kabaret Bździungwa w Klubie Pod Szafotem. Wydział Prawa i Administracji Uniwersytetu Warszawskiego $1975 \mathrm{r}$. 
pomieszczeniach biurowych i pokojach nauczycielskich. Zakwita na krótko, w pierwszej kwadrze miesiąca (po pierwszym).

Wiąże się z nim wiele starych wierzeń i przesądów. I tak na przykład na Mazowszu mawiało się dawniej „Boże, Boże, ach magister nam pomoże". Nie tak dawno jeszcze grupa studentów etnografii i Akademii Wychowania Fizycznego, przebywająca na praktykach, spotkała się z interesującym reliktowym już, a jakże pięknym wierzeniem ludowym. Młode dziewczęta z miejscowości oddalonych od głównych szlaków komunikacyjnych uważały, że korzeń magistra da im szczęście w zamążpójściu.

Czy magister może być szkodliwy dla zdrowia? Pewne światło na to zagadnienie rzucają wypowiedzi uczniów szkół średnich, którzy byli na prelekcji magistra K. Po opuszczeniu sali młodzież stwierdziła spontanicznie „Ale truł”.

Uczeni nie wypowiedzieli się definitywnie co do użyteczności magistra. Wpływ magisterium na rozwój inteligencji i dobrego samopoczucia wydaje się jednak niewątpliwy. W literaturze przedmiotu można znaleźć przypadek niejakiego W. Człowiek ten, nie uważany przez nikogo za odznaczający się szczególną bystrością, po uzyskaniu magisterium oświadczył publicznie „cogito, ergo sum”. Dla ścisłości trzeba jednak dodać, że według innej wersji wypowiedź ta brzmiała „bynajmniej myślę, więc jestem”.

Co do wieku zacnego Jubilata Profesora można zacytować jeszcze jeden wiersz Mistrza Załuckiego.

Jestem już w wieku,

By tak rzec, przeciętnym.

Ten wiek ma swoje wygody,

bo choć dla młodych jestem stary,

za to dla starych ciągle młody. 
Na zakończenie coś od siebie:

Życzę Andrzejowi:

Stałej pogody ducha,

Tekstów kabaretowych, których każdy słucha,

Uniesien słuchaczy i odbiorców skeczy,

Śmiechu, który jak wieść niesie wszelkie schorzenia leczy.

„W Krakowie

Najlepiej czują tu się

Centusie i docentusie"9

9 J. Sztaudynger, Wiórki, Wydawnictwo Śląsk, Katowice 1966, s. 84. 


\section{Tadeusz Winkler-Drews}

\section{Koloryt Andrzeja}

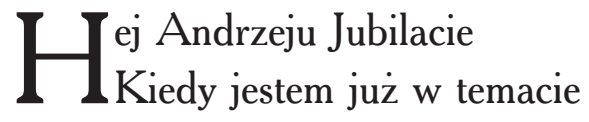

Twej Osoby kolorycie

W mym pryzmacie osobistym

Barwy widzę dość soczyste

Widzę barwy kolorowe

Twojej tęczy zawodowej

Twych dokonań naukowych

Jasno mienią się odcienie

Od barw ciepłych aż po chłodne

Spektrum dosyć różnorodne

Przebadałeś instrumenty

Zwykłe, dziwne i pochodne

Dotykałeś giełdy rdzenia

Zgłębiłeśs ubezpieczenia

Mitologię pchnąłeś z cienia

Spoglądając na Midasa 
Chciałeś dotknąć całą masą

By przeniknąć i zrozumiéc

Jak naprawdę jest $\mathrm{z}$ tą kasą

Tu wymyka się optyka

Tu potrzeba alchemika

Hej Andrzeju Jubilacie

Cieszmy się przy destylacie

Pijmy toast za nieznane i za nowe

Aby zawsze było jasne, kolorowe. 


\section{Julita Wójcik}

\section{Killa (?) twarzy Andrzeja S.}

Wiech mi wolno dzisiaj będzie, złożyć Ci Drogi Profesorze wyrazy I szacunku i uznania dla Twojego dorobku...

... wiem, Drogi Profesorze - takiego tonu nie lubisz... już piszę normalnie:

Korzystając z tego pięknego Jubileuszu, jedno zdanie o mnie: urodziłam się w Warszawie. Czy to ma związek z naszym Jubilatem? Pośrednio.

Pierwszy raz o Profesorze Andrzeju Sopoćko usłyszałam (ok. 30 lat temu) od moich rówieśników, kolegów, którzy po maturze dostąpili zaszczytu wstąpienia w szeregi studentów Wydziału Zarządzania Uniwersytetu Warszawskiego. Wtedy właśnie poznałam pierwsze, ze znanych mi oblicz Andrzeja:

Andrzej Groźny, Wymagający, Andrzej Srogi, ale W Porządku, Andrzej Niepobłażliwy, Andrzej Sprawiedliwy, Andrzej Dokładny, a nawet Andrzej Brzydko Piszący na Tablicy, brakowało tylko określenia:

Andrzej Wszechmogący. 
Śmiało mogę powiedzieć - wzbudzał trwogę u biednych studentów, którym na przełomie lat 80 . i 90. zdawało się, że, zdając egzaminy wstępne na WZ, przeszli przez bramy raju wprost do Krainy Nigdy-Nigdy, polecieli na Księżyc, wszystko mogą i niczego nie muszą się obawiać. Tak było, dopóki nie trzeba było zdać egzaminu u Profesora S.

Wracając do tematu:

Andrzej S. wielki miłośnik psów - szczególnie swoich własnych. Kiedy kupił Szona - obecnie najważniejszego czworonoga w życiu, zapytałam, dlaczego wybrał akurat tę rasę.

Odpowiedział, że gdy Polskę odwiedzi królowa Wielkiej Brytanii, to podczas spotkania (które nie jest przecież wykluczone) będą mieli doskonały temat do rozmów.

Andrzej S. scenarzysta, obdarzony wyjątkowym poczuciem humoru, sprawny organizator, wreszcie - reżyser przedstawień na konferencjach wyjazdowych naszego Wydziału. Podczas spotkań dusza towarzystwa. Skarbnica anegdot, żartów i dowcipów niejednokrotnie opowiadanych w różnych językach. Często powoduje to zresztą sytuacje, w których żart opowiedziany np. po rosyjsku nie zawsze zostaje zrozumiany przez słuchaczy, ale tylko nieliczni potrafią się do tego przyznać...

Andrzej S. - wegetarianin, smakosz, znawca dań i trunków. Kto by przypuszczał, że ten wysoki, postawny mężczyzna jest wegetarianinem. Paliwem Profesora Sopoćko są sałatki, warzywa, owoce, sery, jaja, smalec (to nie pomyłka), ryby i... oczywiście espresso, na które zawsze chętnie daje się zaprosić. $Z$ mojego punktu widzenia wegetarianizm Profesora ma taką zaletę, że biesiadując przy wspólnym stole, nie wyjadamy sobie z talerzy.

Andrzej S. - człowiek bezpośredni, otwarty, szczery, szanujący ludzi za to, jacy są, a nie kim są. Pierwszy raz rozmawiałam z nim i oficjalnie 
przedstawiłam się na konferencji wydziałowej w 2016 roku. Teraz, po 2 latach pracy na jednym wydziale mogę z nieskrywaną dumą powiedzieć: mój kolega z wydziału - Andrzej.

Andrzej S. były Wykładowca/Nauczyciel mojego syna, a może w przyszłości i córki :) $\mathrm{Na}$ tym kończę, żebym nie była posądzona o lizusostwo.

Na zakończenie życzę Ci Andrzeju nieustającego zdrowia, szczęścia, bogactwa duchowego i materialnego, kolejnych, nie mniejszych sukcesów oraz wiele mitości na dalszej drodze życia. 
Scenariusze

autorstwa Profesora

Andrzeja Sopoćko 



\section{Kabaret 2010 rok}

$Z_{\text {szkolenie }}^{\text {espół Pieśni i Tańca przy Wydziale Zarządzania przeprowadzi }}$

\section{Przywitanie AS i RP}

\section{RP. Jak wakacje?}

AS. Wiesz, byłem taki zapracowany, nie miałem wakacji.

RP. No właśnie widziałem Cię na mieście, z jedną panią. Trzymaliście się za rączki i nie tylko. To była żona?

AS. No właściwie nie, żona wyjechała. To tak w zastępstwie, powiedziałbym... duplikat... żony. No ale my tu nudzimy kolegów jakimiś własnymi sprawami, a przed nami całe szkolenie. Swoją drogą jak tu pięknie, jakie krajobrazy. Ach nic mnie tak nie wzrusza jak prosta fujarka młodego pastuszka, jak mawiał Iwaszkiewicz.

Chciałem tylko wyjaśnić, że zespól, choć ma to w nazwie, dzisiaj nie będzie prezentował tańca. Choć miał to być najważniejszy punkt programu. Podeszliśmy do tego ambitnie, postanowiliśmy zaprezentować „Pade catr” z Jeziora Łabędziego, oczywiście z najlepszą obsadą: Nowak, Wierzbiński, Ryć i ja. Bardzo dobrze nam szło. Mielísmy te spódniczki, jak je złożyliśmy, to z nas były zupełne cherubinki. Jeszcze 
te baletki, tzn. puenty. No ale po wielogodzinnych, udanych próbach poszliśmy napić się wody. Tak wody. Mocna była ta woda, to znaczy - mocno zmineralizowana. Zresztą co by nie było, to tyle tego poszło. No może za dużo, bo zgubiliśmy te pantofle do dzióbania na scenie, tzn. te puenty. No i teraz nie damy rady. Ja wiem, że to źle wyszło. Nie będzie tu żadnej puenty.

Ale przecież nie o to chodzi. Najważniejsze, żeby się ciągle dostosowywać do wyzwań współczesności. Potrzeby polskiego rynku pracy skłoniły nas do nadania Wydziałowi profilu inżynierskiego. Niestety nie mamy ani sal ani wykładowców, w związku z tym ów profil zostanie ukształtowany przez pieśń, znaną i śpiewaną przez tysiące inżynierów. Jej słowa nie są skomplikowane, jak nie jest skomplikowana natura inżyniera.

Ja Ci śrubke whręcę...

Skecz 1. Wybory samorzadowe

RP. Oto proszę Państwa znany w naszym powiecie działacz polityczny, znany z najlepszych barów i restauracji, jak też nabożeństw za ojczyznę. A obecnie przebywający, przed niewątpliwie wyczerpującą kampanią, w znanym kurorcie. A może sam nam powie, $w$ jakim celu tu przyjechał?

AS. No, na podryw, tzn. poderwać naród polski z klęczek przed zachodnim kapitalizmem.

RP. To bardzo trudne i na pewno napotyka pan liczne przeszkody.

AS. Oczywiście, sam tego doświadczyłem. Raz, jak właśnie podrywałem się z klęczek to tam nade mną był taki wystający biust. No i podrywając się, utknąłem. 


\section{RP. Na jak długo?}

AS. No tak, na jakieś dwa tygodnie.

\section{RP Wcześniej się nie dało?}

AS. Pewnie by się i dało, ale spadł śnieg i pomyślałem sobie, że jak w tych warunkach poderwę naród, to mi się jeszcze poślizgnie i nie wiadomo, przed kim znowu padnie.

RP. Rozumiem wciśnięty przez los między ograniczenia przestrzeni politycznej (niech Pan powie, duże...?, a jak by tak..) pracował Pan nad programem politycznym. Jakie są jego główne wątki?

AS. Przede wszystkim wartości rodzinne. To jest najważniejsze. W związku z tym pragnę, że by mi oddali nasze wartości rodzinne, to jest młyn pod Poznaniem i emeryturę pradziadka, co odebrano nam za współpracę z NATO. Innym to ordery dawali, a nam zabrali.

RP. A kiedy to wam zabrali?

AS. W 1919.

RP. A przecież wtedy nie było NATO.

AS. Jeszcze nie, ale jego główne filary były i nasza rodzina z takim filarem przez pokolenia pracowała, od samego rana do wieczora. I nawet ją chwalili: sehr Gut, ein gutes Kehrl.

\section{RP. A co na to IPN?}

AS. No właśnie, złożyliśmy papiery, ale oni na razie mają tłumaczy tylko z rosyjskiego.

RP. Rzeczywiście trudna sytuacja, ale miejmy nadzieję, że wszystko będzie dobrze (to znaczy gut będzie) i społeczeństwo pomoże. Na razie pomoże piosenką.

Ja Ci śrubkę whręcę... 


\section{Skecz 2. Mecz}

\section{AS. Teraz zapraszamy na wielkie wydarzenie sportowe, mistrzostwa Europy 2012, mecz Polska-Niemcy. Tu ze studia łączymy się ze stadionem narodowym, halo Robert, jak mnie słyszysz?}

RP. Proszę Państwa, mniejsza o to, jak mnie ten gość ze studia słyszy, My mamy tu co oglądać. Jesteśmy na stadionie narodowym. Jest cała drużyna Premiera Tuska, mimo że dzisiaj nie będzie grała. Ale jest $\mathrm{w}$ towarzystwie licznych masażystek i sponsorów. Widzimy też licznie zgromadzone duchowieństwo. Powiewają szaliki, tak tak, polscy szalikowcy postanowili wesprzeć naszą drużynę. A nie nie, to tylko stuły tak powiewają. Powiewają na całym stadionie. Na pewno przyda się to do podniesienia ducha, czy tam duszy. Ale zawodnicy wybiegają na boisko, Polacy w strojach biało-czerwonych, Niemcy jak zwykle z krzyżami na koszulkach. Nie, nie oczywiście pomyłka, Polacy są z krzyżami, to przecież nasz symbol narodowy, Niemcy są biało-czerwoni, to przecież flaga Hesji, skąd jest większość zawodników naszych gości. No i zawodnicy ruszają, Niemcy opanowali piłkę, nie podają Polakom, nie wiemy dlaczego, znowu podziały na starą i nową Unię, Polacy się bronią jak zwykle przed przeważającą siłą wroga, liczebnie przeważają na naszym polu karnym. Proszę Państwa podanie na główkę, zawodnik niemiecki wyskakuje do góry, Polak nie jest w stanie skoczyć tak wysoko, łapie go za spodenki. Ale jaja, ale jaja. Ale jaja. Proszę Państwa gumka wytrzymała, no jednak solidny wyrób niemiecki. Ale teraz strzał na bramkę, nasz obrońca gdzieś biegnie. No gdzie on biegnie, gdzie on biegnie. No tak, ma telefon od żony, oczywiście, przede wszystkim wartości rodzinne. Gramy dalej w dziesiątkę. I gol, proszę Państwa gol. Tak, strzelił go Polak, a nie, jednak Niemiec. Te niemieckie nazwiska takie podobne do polskich. Tak ale tę sprawę trzeba wyjaśnić, ktoś zbudował ten stadion tak, że nasza bramka znalazła się na wprost strzału zawodnika niemiec- 
kiego. Coś się za tym kryje, tu nam podpowiadają, że na tym stadionie pracowały firmy niemieckie. Trzeba będzie to zbadać, słyszę w dodatku że żona dyrektora była na wakacjach w Izraelu. No gdzie proszę Państwa te nasze służby. Oczywiście trzeba będzie powołać komisję sejmową. A już powstała. Tak tak, idzie teraz do restauracji. No proszę Państwa a tu kolejny skandal, miejsca zajęli posłowie partii niebędącej w komisji. To już brakuje słów na taką bezczelność. Proszę Państwa, komisja nie ma możliwości w restauracji porządnie się narąbać, znaczy nie narąbać, naradzić. $\mathrm{Na}$ razie łączymy się ze studiem

Ja Ci śrubkę wkręcę...

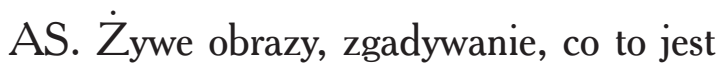

* Kaczka na platformie

* Wierzba płacząca

* Wysoka woda

* Król Jagiełło

AS. Wiersz 1

Gdzie góra, gdzie dół?

Ulewa łączy płynnie

niebo i piekło

$*$

Zielone lato

zaszumiało, wzleciało

błysło, zniknęło... 
Zgubiłam lato

Uczciwego znalazcę

Czeka nagroda

*

Wrzesień wpadł nagle

Pohulał po ulicach

Chyba pijany?

Piosenka 1

Skecz 3. Sylwetka absolwenta.

Wyrabianie ciasta na sylwetkę. Z licznymi komentarzami na temat surowca, gdzie opieprzyć, gdzie smarować miodem, ucisnąć, odpuścić... A potem gotowe ciasteczka w formie ludzików rozdajemy. $\mathrm{Na}$ pożarcie. RP. Jesteśmy teraz w takim poważnym nastroju to i przechodzimy do rzeczy poważnych, to jest do wzorcowej obrony pracy doktorskiej.

Skecz 4. Obrona pracy doktorskiej

RP. Przystępujemy, proszę Państwa do ostatniego etapu pracy doktorskiej, to znaczy do obrony rozprawy, tu pt. „Tunele czasoprzestrzeni na Suwalszczý́nie”. Autorem jest mgr Leszek Kornik, promotor dr hab. Przemysław Kocioł, recenzenci: prof. Henryk Dzięcioł, prof. dr hab. Lucyna Sarna. Recenzje są pozytywne, choć krytyczne. 
Autoreferat: Praca moja zaczęła się od spostrzeżenia, że w pewnym rejonie Polski pojawiają się elementy innego czasu, jak np. plakat koła gospodyń wiejskich „Dziarskim kroczem (krokiem) w nowy ustrój”, czy „Ruski potrafi” (dział rzeczy zagubiony KP), a nawet „Bądź czujny, reakcja się rozwija" (na terenie bimbrowni obywatela Zdzicha F.). Dowiedziałem się też w pobliskim sklepie GS, że kilku obywateli tej miejscowości było niedawno na orbicie. W związku z tym próbowałem przeprowadzić wywiad. Niestety, nie otrzymałem wyczerpujących odpowiedzi, a jedynie ostrzeżenie, że kontynuacja tych prób spowoduje trafienie mnie jakimś ciałem stałym. Wskutek tego mógłbym udać się nieprzygotowanym w podróż kosmiczną. Dokładnie brzmiało to „aż tym łbem w gwiazdy zaje...(chyba zajedziesz?)

RP. Teraz prosimy o odczytanie recenzji przez prof. Sarnę.

MK. Ja nie będę czytać całej recenzji, przejdę do wniosków końcowych. Otóż ja cenię to jak Kornik pisze, bo wtedy się nie rozmnaża, a po co nam tyle Korników (glos z glębi - ale on ma tylko wtedy ręce zajęte).

RP. Proszę nie zakłócać. Rozumiem, że konkluzja jest pozytywna. A teraz prosimy profesora Dzięcioła.

Profesor Dzięcioł: Takimi jak Kornik to ja się zajmuje od dawna i ja takich wyciągnę z każdego tunelu, razem z wnioskami.

Profesor Kocioł: Nie możemy dopuścić, by Dzięcioł znęcał się nad Kornikiem...

RP: Może jako pierwszej damy głos kobiecie, pani profesor Sarna. No nie ma Sarny, przez tę awanturę powiedziała, że jest taka spłoszona. No nie, tu sam anioł nie da rady.

Anioł: Oto jestem.

RP: Jesteśmy zaszczyceni, ale co Anioł z taką pałą... Ach to przecież Anioł stróż.

Anioł: No, chodźcie dzieci do mnie. Chodźcie, bo jak przyp... 
Wszyscy tula się do Aniota

Anioł: No dobra, rachunek prześlę jutro, a teraz muszę... Mam drugi etat, ja wiem, że to dziwnie wygląda, ale chłopaki nie mają tam minimum kadrowego. Trzeba pomóc, robimy przecież w tej samej branży.

\section{Piosenka 2}

AS. Teraz dalsza część szkolenia. Bo proszę Państwa, ci młodzi to tak wpatrzeni w te komputery, że jak na przykład przychodzi taki jeden do takiej jednej to mówi: wiesz bardzo mi się podobasz, no tak mi się podobasz, że chciałbym mieć z Tobą... publikację.

No nie, publikacje piszemy samodzielnie, a to, co trzeba, we dwoje, to lepiej tak po prostu. W związku z tym sięgamy po klasykę. Wé́my np. jak Cyrano de Bergerac. O nim trochę pisano, sam zresztą sam też pisał. Ostatnio znaleziono taki jeden jego tekst. Oczywiście w archiwach IPN. Okazało się, że i na niego bezpieka szukała haków. Francuz bo Francuz, ale ważny.

Bój prochu duchotą zamiera

$\mathrm{Na}$ murach już kończą pacierze

Przez mgłę gdzieś Twój obraz przebiega

I z wiatrem Twój zapach się mierzy

Wieczór jest cichy i słodki

Jak Twej modlitwy przed spaniem dotyk

Niech sen mnie ku niej zabierze

A myśli niech $\mathrm{Ci}$ pod stopy

Pójdą wiosenną tąkę rozśsielić

Wystrzały zamilkły w zmierzchaniu

I ciszę jak księgę otwarly

W tej księdze jest tylko Twe imię

Roxano, Roxano, Roxano 
Przekładam jak kartki tygodnie

$\mathrm{Na}$ każdej tak świat się odmienia

Lecz pamięć Twych oczu niezmienna

Codziennym przychodzi świtaniem

Ten list kawał świata przemierzy

A kiedy już ręce Twe dotknie wargami

Pył Flandrii i skwary Owernii

$Z$ mych oczu się wzniosą tumanem

Twój obraz ponownie odsłonić

To nic, że widziani jesteśmy osobno

Któż serce dostrzeże w ukłonie

Lub radość w spojrzeniu przelotnym

A przecież są one tym mostem tęczowym

$\mathrm{Na}$ którym spotkamy się kiedyś

Państwo patrzycie, czyj to obraz był dla mnie natchnieniem. No niestety, obrazu Roxany jeszcze szukają. Postanowiliśmy więc znaleźć jakiś obraz kobiety, o której nawet najmniejszej przychylności marzą wszyscy mężczyźni. Łatwo się domyśleć, o kogo chodzi. Nie, nie Dorotę Rabczewską też braliśmy pod uwagę. Ale kto inny okazał się bezkonkurencyjny. Oczywiście. Rektor Katarzyna Chałasińska-Macukow.

I tym wzniosłym akcentem przechodzimy do części nieoficjalnej... 


\title{
Kabaret 2011 rok
}

\author{
C rupa bojowa „Taki żart” \\ zaprasza na program obronny
}

Wprowadzenie

RP. Co ty masz tam, za sobą?

AS. No, karabin. Taki mój znajomy, Vincent...

RP. To ktoś z zagranicy?

AS. No on był z zagranicy, teraz nie jest, ale jak mówi to przeważnie z zagranicy.

RP. W tym kraju to nawet jak coś jest proste, to i tak pokręcone.

AS. No i on mówil, że będzie wojna.

RP. Z kim?

AS. Tego nie powiedział, ale patrzył za słońcem.

RP Z zachodu na wschód?

AS. Nie, całkiem odwrotnie. 
RP. No to rozumiem. Musimy się przygotować, jakieś ciepłe kufajki, słonina i trochę spirytusu, żeby $w$ lufach nie zamarzało. Ale ten Twój karabin to z plastiku.

AS. No bo on nie jest do strzelania, tylko do rozbrajania. Trochę sobie z nimi pogadamy, pożartujemy. Może damy sobie w Gazprom, dziewczyny potańczą przy rurze. I dojdzie do rozbrojenia.

RP. To taki program ma nasz Sztab Generalny?

AS. Tajemnica państwowa. Nie potwierdzam, ani nie zaprzeczam. Ale ludzie podobno widzieli, jak tarczę antyrakietową przerabiają na stół. Szwedzki. Wiesz śledzik i tam dalej. Więcej jednak nie możemy powiedzieć. Pogadajmy o czym innym. Wakacje się skończyły. Styszałem, że byłeś u Ojca Dyrektora. Jak tam - ilu tam spaliliście na stosie?

RP. Nie, ja byłem z ojcem Dyrektorem Lasów Toruńskich. Na grzybach. I znaleźliśmy jednego rydzyka. Marynowanego. I pół litra. Tak się rozkręciliśmy, że nadawaliśmy na całą okolicę. Zbiegła się cała służba leśna, każdy coś przyniósł. Jak się tak parę razy chlapnie pod jagódkę, to ta przyroda tak pięknie potrafi zaszumieć... Tylko potem już nie mogłem rozpoznać jagódek i zakąszaliśmy, co się nawinęło. Zdaje się że połknąłem..., a co tam, nieważne. No ale żeby aż tyle koni chodziło po lesie...

AS. Tak to jest z tymi mediami. Ja już jestem obojętny na to, co podają.

Nawet jak czytam instrukcję pożarniczą, to się nie zapalam.

RP. A ty byłeś na wsi, no jak tam nasz wiejski lud pracowity? Cóż on teraz porabia?

AS. Jak zwykle dominują tradycyjne wiejskie zajęcia: kłusownictwo, bimbrownictwo, przemytnictwo.

RP. Ach ta piękna nasza ludowa tradycja. No i oczywiście uprawa roli. 
AS. Nie widziałem, może gdzieś pokątnie, jakieś konopie indyjskie, no tak, żeby dostać dopłaty.

No tak, my tu ze sobą gadamy, ale trzeba wrócić do spraw poważnych.

O uzbrojeniu już mówiliśmy, ale trzeba przecież przeanalizować nasz potencjał ludzki. Przecież, jak to mówią górale, nie człowiek jest dla szabasu, ale szabas dla człowieka.

RP. Górale?

AS. Górale. Górale ze Wzgórz Golan.

\section{Skecz. Student}

Oto student. Tu ma nogi do podchodzenia do egzaminu (podchodzi i wraca kilka razy). Student podchodzi do egzaminu wielokrotnie.

Potem jest pasek albo szelki.

No, ale poniżej.

Poniżej nie ma nic ważnego, no może - intersującego, no lepiej, tak bym powiedział, te dowcipy, które ich najbardziej cieszą

Tu są ręce. Służą one do okazywania poziomu wiedzy studenta. No, jaka jest różnica między... - rozkłada ręce

To jest Komórka. Służy do przekazywania najważniejszych komunikatów „ty wiesz, jaka wczoraj była impreza, normalnie... Nie mogą teraz mówić, bo ten, co przy tablicy będzie się czepiał”.

To jest Głowa. W głowie znajduje się mózg. Funkcje tego organu na Wydziale nie zostały dotąd zidentyfikowane.

Tu jest serce. Jak serce matki, dba, by wykładowca się nie przemęczał, zawsze chciałby skrócić zajęcia.

Tu jest pierś. No, czasem dwie. Przydatne, o przydatne, ale po zajęciach. 


\section{Piosenka. Kadecik}

\section{Wiersz. Wielkanoc '2011}

Nastała wiosna, ptaków śpiew,

Unosi błękit nad głowami, Las zielenieje - Wisły brzeg,

Radości czas witamy.

Mówisz mi - Bocian w niebie lśni,

Zawilców biel ziemię ściele,

Słonecznie długie będą dni,

A nam w nich - coraz weselej.

Wiewiórka ruda, po zimie znów,

$\mathrm{Na}$ sośnie szyszki goni,

Każdego pozdrów w drodze swej,

Uśmiech mu daj na dłoni.

Poniosą je w rodzinny dom,

Z nim siądą wokół stołu,

Jajeczkiem się przełamią,

I będzie im wesoło!

Za stołem pełnym potraw stu,

Wraz będą się weselić,

Bo to jedyne, co w ten dzień,

Powinni ludzie dzielić.

A na obrusie białym pisanki kolorowe,

Do polek i mazurków, jak zawsze są gotowe, 
Podobnie jak baranek i lukrowane baby,

W radosne ruszą tany, po Poniedziałek Lany.

Nastała wiosna, dzień już trwa,

Od rana do wieczora,

A Święta Wielkiej Nocy,

To wszak radości pora!

Więc życzę Wam wesela moc,

Z nim zdrowie przyjdzie samo,

Śmiechem witajcie każdy dzień,

Budząc się wcześnie rano.

\section{Piosenka. Ula Gulan}

\section{Skecz. Szpagat}

Wpada gość w sportowym stroju, robi rozgrzewkę i z nitek skręca szpagat. Mocny. Brawa

Piosenka. Jagienka

Wiersz. Haiku majowe (2011)

W sklepie grupa manekinów

Odśrodkowo stoją gotowi

Pęd obcasów skierowany w górę

Wnet wniebowzięcie 
To samo miejsce

Inny obrót Ziemi

W białej filizance

Czarny krąg kawy

*

Domy puszczają zajączki

Oknami do siebie

Powolny przepływ światła

Haiku miasta

$*$

\section{Summerglim (2011)}

In the canion of garbage

All roads are more taken

Nothing new under the blazing sun

Lonely in Naples

$*$

At the end of the labirynth

There is an empty space

Where you and your shadow

Become one

*

Kawa czarna, płomienna

Krągła cisza po deszczu

Kręci się Ziemia, pędzi

Gwiazd galaktyka 
Burza zstąpiła na ziemię

Pod postacią rzeki

Łączą się drogi świata

Wpław

$*$

Początek miasta, początek świata

Kamienie na wzgórzu

Wyznaczają inicjał

W opowieści

\section{Skecz. Wybory}

Kandydat 1. Moim programem jest pieśn patriotyczna. „Moja miła Maniu. Pójdziemy do lasa. Pośród leśnej kniei weźmiesz mnie za ramię." Może nie tyle patriotyczna co państwowotwórcza. Las jest państwowy.

Kandydat 2. Ja uważam, że powinniśmy się skoncentrować na sprawach gospodarczych. Trzeba podwyższyć nauczycielom, leśnikom, górnikom, hutnikom, diabetykom, emerytom, epileptykom, kolejarzom, balejażom, pani Ani i Eli...

A skad na to brać?

Obetniemy emeryturę Jaruzelskiemu

Może nie starczyć...

No to obetniemy temu, co był szefem MFW i się uganiał za tamtą... Zdaje się, że jemu jest co obciąć. 
Kandydat 3. Powinniśmy spojrzeć prawdzie w oczy. Żyjemy w państwie bezprawia. Na przykład się dopuszcza, że mój sąsiad jest rozpustnikiem. I co robi?

Jest sexofonistą.

Saksofonista?

No może. Gra na organach.

To on ma organy?

Pewnie że ma. Moja żona kiedyś mówiła do kuzynki: Jolka, żebyś Ty je widziała...

Na tym kończymy prezentację tych, którzy będa podejmowali decyzje $w$ imieniu Ojczyzny. Jak widać, różniq się oni między sobą, ale temat zainteresowań jest jeden.... Dobro naszego kraju. Życzymy im, jak sami mówili, dobrej kasy..., to znaczy - dobrej passy... w wyborach.

\section{Wiersz. Кладбище на Окрайне}

Эй сынкове миленкие

Так далеко вы ушли

Войны громкие барабаны

В чужой страну поведли

Вам берёзы седовы

Поклониљись к земљи

По дорогах в ваше следы

Слёзы матерь увезли

Смерть вокруг вас таньцевала

Впрежде в сердце вбила клы 
Долго в плени наигралась

Растирая гордость в пыљ

В конце пришёл горкий сен

Среди леса колебания

Странный дерев розговоров

Но с даљека посљышите

Думки грустной пень радною

Да вам плечи поднимает

Степный ветер, маков цвет

И на знамях повышает

Там где лавку Бог имеет

А в ней баљсам укоения

Мати в ночи прикоснение

Виляющий собак хвост

Запах хлеба в жатвы время

И церковнуй в Пасху хор

От надеждый что померли

Пйсм несющих стршный плач

Эхо пойдеть в земный шар

Как молљитвы матерь ткания

Хранить будеть

Что военны

Не торгали го крутя

Piosenka M. Flaszczyńskiej. O dani wieczer 
Tak się jakoś smutno porobiło. Może opowiemy jakiś dowcip. Może ten ze znanej serii: przychodzi Baba do Dziekana.

\section{Skecz. Przychodzi baba do Dziekana}

Co pani jest?

Bieda.

To zaczekać.

Ty, dlaczego jej gdzieś tam het, np. na SGH nie pogonisz?

Widzisz. Przyjdzie do mnie np. taki Sopoćko i powie, że już mu się wnuki zestarzały od czasu ostatniej podwyżki. Przecież pieniądze na Wydziale są. A ja mu powiem: Teraz są, ale zobacz, co jest za progiem.

\section{Wiersz}

Drodzy poeci,

Pozwólcie kwiatom spokojnie rosnąć

A człowiekowi wejść do ciepłego pokoju,

Niech przyzna się wreszcie, że lubi seriale i sernik

Niech zje obiad bez wzruszeń modląc się w talerz i myśląc o obiedzie, A wieczorem przejdzie się na spacer swoim najzwyklejszym krokiem By miał szansę zauważyć, że ma dobrą pogodę zamiast deszczowej Bez wspomnien, bez tęsknot, bez omdlewających liści

Pozwólcie mu wrócić do domu z siatką pełną zakupów.

Kolczyk

W ucho wpinam jeden kolczyk

Tylko z lewej strony 
Niektórzy wtedy pytają czemu,

Czemu jeden, czy drugi zgubiony?

Odpowiadam im wszystkim, że kaprys to,

Kaprys - mówią, a myślą: „by być bardziej przewrotną”

A prawda jest taka, że prawą stronę głowy mam po prostu cięższą i bardziej samotną.

\section{Piosenka. Ula Gulan}

Skecz. Jak się pisze pracę naukowa

Siadamy do komputera. I buuch... Strzelamy sobie piwko. I zaraz otwieramy Internet. Sprawdzamy, ile mamy na koncie. Z rozpaczy strzelamy sobie drzemkę. Ale nie trafiamy, bo nam to nie daje spokoju. I siedzimy. I buuch... Strzela nam w krzyżu, jak sięgamy po długopis. Czekamy, aż przyjdzie. Coś do głowy. Przychodzi, ale nie tam. No to się tam drapiemy. Lepiej zasłonić okno. Patrzymy w przyszłość. Widzimy autostrady. W natchnieniu, nie patrzymy na ceny benzyny. Widzimy: euro się obsuwa. Tusk podpiera je jakąśs belką. Nie daje rady, bo Rosjanie podają mu błędny kurs. My to prostujemy, bo się nie możemy połapać. Podsuwamy tekst znanej piosenki, euro dolar dwa bratanki (przepraszam ... jak dwa franki). Robimy przypisy tych, co nie mają racji. $\mathrm{Ci}$ drudzy to nasi naśladowcy. Nie warto wspominać. Odkrywamy, że wszystko jest proste. Opisujemy tak, że nie daje się zrozumieć. Dajemy szwagrowi do recenzji. Szwagier daje nam swoje. Nic nie rozumiemy, występujemy więc dla niego o nagrodę państwową. Dostaje ją nie nasz szwagier. Widzimy, że upadek nauki jest bliski. Dzwonimy do agencji. Najpierw wydawniczej. A potem już jaka się trafi. Targujemy się. 


\section{Piosenka. Ula Gulan}

Skecz. Wywiad z kosmonauta

Prowadzący: właśnie mamy przyjemność rozmawiać z polskim kosmonautą, który na własnym sprzęcie znalazł się w odległym rejonie kosmosu.

Kosmonauta: Od dziecka marzyłem o kosmosie i od razu podjąłem próby skonstruowania pojazdu kosmicznego. Zacząłem od paliwa, na początku jednak uzyskana moc była niewielka, jakieś 20\%. Daleko mi było jeszcze do przysłowiowych 45 , ale ostatnio już osiągam prawie $75 \%$.

\section{P. Pewnie technologia jest objęta tajemnicą?}

K. Niespecjalnie. Najtrudniej zdobyć te miedziane rurki. No i trzeba reaktor tak przykryć, żeby nie bulgotało, bo zaraz przyjdą inni, ci no... Inni kosmonauci.

P. No, ale jak to było $\mathrm{z}$ tą ostatnią wyprawą?

K. No więc wszedłem na orbitę (z rowerem), wszystko zaczęło krążý, grawitacja też. Raz był u dołu, raz u góry. Aż tu patrzę jestem na kursie kolizyjnym.

\section{P. $\mathrm{Z}$ jakimś innym statkiem kosmicznym?}

K. Na pewno. Cały czas dawał sygnały: zielony, zółty, czerwony, zielony, źółty, czerwony. No i tak mnie wybiło w przestrzeń, że spotkałem kosmitów.

\section{P. Takich zielonych?}

K. Raczej niebieskich, takich w czapeczkach z daszkiem. Byli bardzo mili. Pan to chyba zabłądził w tej galaktyce. Poprawilem ich, że nie w... ale po... galantynie z drobiu. Zaszkodziła. Potem czasoprzestrzeń się 
zamknęła i rano jak ją cieć otworzył... no tak, po prostu... kluczem, okazało się, że jestem z powrotem.

\section{P. Przy produkcji paliwa.}

K. Nie, w jakiejś izbie.

\section{P. Wiejskiej?}

Chciałbym na Wiejskiej, bo tam jest pełne zrozumienie dla tych no, kosmonautów. Było to tam, no wiesz gdzie... na Woli, chociaż niektórzy bywają i tu, i tu. Sami znajomi, ale wszystko w atmosferze serdeczności. Nawet mówili: panie Józiek, damy panu abonament, co pan będziesz tak każdym razem iskał się z tych trzech stów. Odmówiłem. No jak się wyjeżdża z kraju, to ostatecznie na taki wyjazd można trochę wydać. Ale żeby za powrót żądać trzy stówy, to tylko może być w tym cholernym państwie.

\section{Zakończenie}

Jak widzicie Państwo nasza technologia obronna już sięgnęła kosmosu, jesteśmy przygotowani do podjęcia działań na tym froncie, szczególnie pod względem zasobów paliwa... kosmicznego.

A Pani co tu robi, my mamy poważne szkolenie?

\section{Bubliczki}

Zapadła noc głucha,

W latarnie wiatr dmucha.

Ktoś pieśni mej słucha,

Czart chyba sam!

Idę, gdzie los gna mnie,

Choć miasta pól zna mnie, 
Nie patrzy nikt na mnie

Ni na mój kram.

Ach, kupcie bubliczki,

Gorące bubliczki,

Gdy dacie rubliczki,

Nakarmię was!

Tę prośbę mam jedną:

Gdy gwiazdy w krąg zbledną,

Wspomóżcie mnie biedną

Choć jeden raz.

Kto papa mój, mama,

Ja nie wiem dziś sama,

Dziewczyna, nie dama,

Mam od was mniej!

Lecz zaal mój jest krótki,

Dwóch chłopców, trzy wódki

I idą precz smutki

Przy pieśni tej:

Ach, kupcie bubliczki,

Gorące bubliczki,

Gdy dacie rubliczki,

Nakarmię was!

Tę prośbę mam jedną:

Gdy gwiazdy w krąg zbledną,

Wspomóżcie mnie biedną

Choć jeden raz.

A jak w tej złej dobie

Zarobię coś sobie,

To wielki bal zrobię,

A ze mną wy! 
Noc całą, bez zmiany,

Od ściany do ściany,

Harmonia i tany

Wciąż będą szły!

Ach, kupcie bubliczki,

Gorące bubliczki,

Gdy dacie rubliczki,

Nakarmię was!

Tę prośbę mam jedną:

Gdy gwiazdy w krąg zbledną,

Wspomóżcie mnie biedną

Choć jeden raz. 


\section{Kabaret 2013 rok}

Wejście piosenka śpiewana $w$ killka osób (,Niech żyje bal”)

\section{Wejście}

1. Postanowiliśmy dać dobry przykład studentom i uruchomić własną działalność gospodarczą. Pod patronatem Dziekana i oczywiście wspierani przez Ojca Dyrektora. (AS wykonuje pewne ruchy ręka)

2. No nie, żeby od razu Dolina Krzemowa. Na razie robimy w gastronomii, taka restauracja.

1. Znaleźliśmy dobrą lokalizację. Róg Orła Białego i Maciarewicza.

2. Chyba Mickiewicza.

1. $\mathrm{Na}$ razie to jest Mickiewicza, ale trzeba przewidywać przyszłość.

2. Postanowiliśmy nazwać ją jakoś swojsko. I tak po przejrzeniu wszystkich gazet...

1. Wszystkich?

2. No te najważniejsze: no ta "Wybiórcza”, „Z rurą w przyszłość" (organ polskich hydraulików za granica), „Świerszczyk i myszka”... 
1. To ty te pornosy też czytasz?

2. Naród czyta. Ja z narodem, naród ze mną. No, ale mniejsza. Pokażę ci parę sztuk. Niektórych numerów to chyba nawet ty nie próbowałeś.

1. W każdym razu wyszło, że Polak najbardziej myśli o... (zwrot do publiczności), nie, nie (oj zbytniki)... o strefie euro.

2. Nazwaliśmy restaurację "Strefa euro”. Ojcze Dyrektorze coś nie tak (AS łapie się za głowę). A prawda. Miało być „Strefa Euro. Dom Pątników", ale dół szyldu zasłaniał nam i tak ekran akustyczny i zostaliśmy przy „Strefie...” (AS wzdycha i kiwa ze zrozumieniem głowa)

1. Dołożyliśmy też taki akcent polski w tytule. No wiesz, ale czy teraz tu ktoś przyjdzie? Narobiło się przecież w tej strefie...

2. Ty zobacz, już ktoś idzie..

3. (ubrany $w$ papachę) Dobro pożalowat'. Możno wejt' i, czto nie bud' poluczyt'

1. No gdzie, no gdzie w papachach nie przyjmujemy. W turbanach zresztą też. Może być topless, Ferrari albo Maserati...

2. O patrz jakiśs Norweg.

3. (czapka norweska) God kveld. Można tu u was coś dostać?

2. God kveld. Inngangen er fri. Witamy serdecznie, co Pan sobie życzy.

3. Ale u was bałagan, może byście jakoś posprzątali.

1. Już się robi (sprzątanie, ale stót stoi do góry nogami).

3. A to (pokazuje stót), przecież to bez sensu.

2. No nie możemy, musimy przestrzegać Dyrektyw.

3. Co jest w ofercie?

2. Sałatka grecka. 
3. Że to się wam nie znudziło. Ale dawajcie. Ile kosztuje?

1. Tu mamy cenę.

3. Czy wyście powariowali?

1. No rzeczywiście, no to przesada. Wie Pan, ale mamy takiego księgowego, on jest właściwie na wylocie. Vincent, Vincent, no jak to to znowu policzyłes...

Pan zapłaci, ile Pan uważa, a różnice ściągniemy z funduszy na naukę.

2. Działalność gastronomiczna to jednak nie jest główny cel naszego przedsięwzięcia. Chcemy wciągnąć społeczeństwo w europejski obieg kulturalny. Tak jak było kiedyś, za czasów wspaniałych chłopców we frakach i kobiet sunących w długich sukniach od Diora, przez Kudowę do Karlovych Varów. I żeby było śmiesznie, i lirycznie.

Spojrzenie na Ojca Dyrektora, coś nie tak?

I patriotycznie oczywiście.

„Gdzie sq chtopcy z tamtych lat”. Sala powtarza „Kto wie czy byto tak... Kto wie czy byto tak..."

2. No, ale już jak sięgamy do przeszłości, to się już tak nie ograniczajmy, sięgnijmy do początków Unii Europejskiej. Nie tam jakiś traktat rzymski, sięgnijmy do prawdziwych początków.

\section{Zjazd Gnieźnieński}

Oto OTTO (cholera z tym niemieckim) Otton III Przywódca Germanii.

A to Przywódca Sklawinii Boleslaw (trochę się przepychali krzesłami z palatynem Bezprymem, ale w końcu dało się to jakoś załatwić). Witaja się na misia 
B. No wiesz, teraz, jak na nas patrzą, to musimy udawać, że jest między nami dystans.

O. Kto tak uważa?

B. Kniaź Jarosław. No, ale też słyszałem, że ty z tymi od wschodu jakąś rurę macie przeciągać, koło tych Vikingów.

O. To są takie plotki, były takie plany, ale wiesz, zanim to by się uruchomiło, to minie może i z tysiąc lat.

B. No tak, zresztą mu do tego czasu i tak nie oddamy władzy. Ale jakby co, to przecież w waszej drużynie jest kilku naszych, rycerz Robert, rycerz Łukasz, Kuba itd. Rozmawiałem z królem Bawarii i on tam im by trochę więcej zapłacił.

O. No nie róbmy sobie przykrości. Przecież jest umowa. Wy dajecie nam ludzi do drużyny, a my wam dyrektorów banków. Jedni i drudzy zarabiają podobnie.

B. Fakt, ale nie wiem, co tych waszych dyrektorów tak do Polski ciągnie?

O. No, macie takie piękne lasy, tyle zwierzyny...

B. Jakiej zwierzyny?

O. Np. jeleni. O tam jeden taki idzie.

Wchodzi nieśmiaty typ „przepraszam, czy tu można byłoby założyć lokatę?"

U nas w bankach jest teraz wielka akcja „Jedź do Polski na jelenie” Piosenka o pieniqdzach 


\section{Casting na posade}

Proszę Państwa. Nasz Wydziat dba także o absolwentów. Przede wszystkim szkolimy studentów końcowych lat studiów, jak zdobyć pracę. Oto krótki case szkoleniowy, jak dostać upragniona pracę:

A. Dzień dobry (caluje $w$ ręelę). Słyszałem, że można dostać pracę przy przerzucaniu koksu.

P. Się zobaczy. Weźmiemy kwestionariusz. Kultura ogólna - może być. Jakie jest wykształcenie?

A. Tu jest dyplom ukończenia studiów, kursy...

P. Hobby jakieś...?

A. No normalnie, tak jak wszyscy, dziewczyny...

P. ????

A. Nie, nie, chłopaki.

P. No.

P. A co to jest, jakiś przewód doktorski otwarty? Coś pan tu z lewatywą przyszedł?

A. Nie, no ja bym tak chciał się na doktora.

P. Na doktora, to do szpitala. Będą się później czepiali, że pod przykrywką kotłowni prowadzimy nielegalny interes. Że niby mają się spocić i przeziębić, a potem mamy ich leczyć. $\mathrm{Na}$ chorych mają zarabiać polscy lekarze, na zdrowych angielscy pracodawcy. Porządek musi być.

Dobra, a co Pan wie o koksie?

A. Surowiec używany głównie w hutnictwie, ale też do celów grzewczych (bez sensu)... no co, tak mi się powiedziało. $\mathrm{Na}$ 
giełdzie w New Castle cena 540 USD/t, w Amsterdamie na AMM - 523...

P. A u Grubego na Targówku ...

A. Nie wiem.

P. Znaczy nieprzygotowany. No, ale jakaś praktyka?

A. Pracowałem w kotłowni w agencji towarzyskiej.

P. I wyrzucili?

A. Nie. Miałem bardzo dobre oceny. Bardzo dobrze posługiwałem się długim trzonkiem szufli. Na koks. Bo inni, to jest specjaliści od krótkich trzonków, to nie potrafili rozgrzać. Pieca znaczy się. Ale musiałem odejść.

P. Bo co?

A. No bo żona mówiła, że jak tam szedłem, żeby ten ogień... to byłem taki napalony... Bała się, że się przeziębię.

P. No dobrze. Weźmiemy na okres próbny. No to łap się pan za ten... (zwraca się do Sali) nie podpowiadać... uchwyt i do roboty.

\section{Wiersze o gorącej mitości}

Na tawce siedzi pan $w$ kapeluszu i czyta gazetę. Przysiada się do niego drugi. Przez pewien czas zaglada przez ramię. Potem macha ręka...

\section{Szmonces}

Goldberg: Ech...

Rapaport. I pan mnie to mówisz? 
G. O czym oni piszą w tych gazetach. A wiesz Pan, Lipszycowi zajęli sklep.

R. Co to za sklep. Tam wszystko było, z wyjątkiem klientów.

G. Ale przecież Lipszyc miał kupę pieniędzy?

R. Miał, ale się ożenił. Mając osiemdziesiąt lat. Żona niczego sobie, o 60 lat młodsza.

G. Coś pan, mówili, że to małżeństwo z miłości?

R. Tak, tak. Jak ona kochała pieniądze.

G. Ale wiesz pan, ona spodziewa się dziecka. Cała kamienica o tym mówi.

R. Na szczęście jeszcze można liczyć na pomoc sąsiedzką.

G. Dajmy spokój Lipszycowi. Ja słyszałem, panie Rapaport, że pana żona w szpitalu. Jest tak źle, że wszystkiego można się spodziewać.

R. Ech, wcale nie wszystkiego, są inni spadkobiercy...

Piosenka: A biedna Rebeka, wciqż na niego czeka

Wchodzi gość i siada przy stoliku

\section{Reprezentant Polski}

1. Popatrz znowu ktoś przyszedł. Twarz jakaś mi znana.

2. No co ty, nie wiesz? To prawoskrzydłowy z Wicher Kobyłka.

1. Fakt. Fornalik ma powołać do kadry narodowej, bo w pierwszej i drugiej lidze już gra sam Mozambik, Albania i Wyspy Dziewicze. 


\section{Dziewicze w PZPN?}

1. Tak się nazywają. A co? Jest u nas NFOZ. On nas chroni, żebyśmy do lekarzy nie chodzili. Za życia. Słyszałem, że są już zapisy na 2040 rok. Na rentgen kości, no a przecież, co prześwietlać, chyba widać...

2. No to może pogadajmy z naszym znakomitym zawodnikiem. Dzień dobry Panie Romanie, wszyscy teraz mówią o tej wygranej z Niemcami.

Zawodnik. No wygraliśmy, ale ciężko było.

2. Dlaczego ciężko?

Z. Bo byliśmy tylko we dwóch.

2. Dlaczego tylko dwóch? To ten sędzia nieźle poszalał.

Z. Ale Niemców też było dwóch.

2. To rzeczywiście fascynujący był mecz.

Z. Mecz jak mecz, taka po prostu gra.

2 Futbol to rzeczywiście wspaniała gra.

Z. Coś pan, jaki futbol? Graliśmy w makao. 


\section{Kabaret 2014 rok}

Skecz 1. Otwarcie punktu wyborczego

Gaśnie światto. Ciemno. Stychać głosy męskiego zdenerwowania.

Co jest z tym światłem? Gdzie jest jakiś elektryk, znowu nie przyszedł na wybory?

Nie wiem, gdzieś się wałęsa. Ale to niebezpieczny gość.

A. Jak to niebezpieczny?

B. Stale jakieś spięcia powoduje. Łączy te plusy z minusami...

A. No to ok?

B. Ale te plusy okazują się ujemne. I wtedy jak kopnie.

A. On?

B. Nie on. Życie. I później na całe życie ma się taki wPiS. Nie ma wyjścia. Już tam pozostanie.

Zapala się światto.

A. No wreszcie. Dawaj tę urnę!

Przynosi stoik po ogórkach. Zostaty jeszcze dwa. 
B. Oto mamy przejrzysty system wyborczy. Wszystko widać. Nie mamy nic do ukrycia.

A. To nie mogłeś wyjąć tych ogórków?

B. To premia dla pierwszych głosujących. Miały być tablety, ale jak nam kelner policzył za tę naradę ,jak zwiększyć frekwencje”, to dobrze, że i na to starczyło.

A. No, ale się karty pobrudzą.

B. Jak pobrudzą. Tu mam wszystko w czyściutkiej kopercie, ładnie wszystko wypełnione, kaligrafia...

A. Przecież powiedzą, że fałszerstwo.

B. Jakie fałszerstwo, sam wszystko wypełniłem? Od nikogo nie ściągałem. Możesz dać to w „Plagiat” jak chcesz. Nic nie wyjdzie. Chyba że dołączysz programy wyborcze? Wtedy będzie prawie $100 \%$.

A. Dlaczego prawie?

B. Bo daty mogą się różnić.

A. No dobrze, a jak to wszystko rozpisałeś?

B. Dałem wszystkim po równo. Chłopaki gdzie indziej też tak robią. Oni wszyscy tacy sami, byle kasa, balanga i telewizja. Wiesz, że nawet Związek Kynologiczny na jakiśs swój kongres to musi jechać za granicę?

A. Gdzie?

B. Na Azory.

A. $\mathrm{C} i$ to mają, co lubią. Dobrze, ale jak tam ludzi na listach poustawiałeś? Jak mój szwagier?

B. Jest. $\mathrm{Na}$ drugim miejscu?

A. Dlaczego na drugim? 
B. Bo chyba dali jakieś stare formularze. Tyle tych wyborów, że oszczędzają. Na pierwszym był już wpisany Edward Gierek.

Wchodzi kobieta, rozgląda się.

C. Mówili, że trzeba tu przyjść, ale ja przecież mam wszystko opłacone, a jak mi przyśle alimenty, to nawet abonament bym...

A. Nie, nie. Pani tu nic nie płaci, możemy Panią poczęstować nawet krakersami, zostały jeszcze z tych europejskich... No i naszym przysmakiem regionalnym.

C. A co to jest?

B. Ogórek kiszony w czekoladzie, tj. nie w czekoladzie tylko w słoiku, nie - w urnie. Nie, jaka tam kurna urna. Ogórek wyborczy. Bo kiełbasę, ze względu na pomór świń w Suwalskiem wycofali.

C. A kogo ja mam wybierać?

A. No tych do rządu. Ale najpierw poprosimy o dowód osobisty.

C. Zaraz, zaraz (szuka dtugo $w$ torbie), no chwilę (dalej szuka), no jest (wyjmuje szminkę i lusterko, poprawia sobie malunek).

A. To miał być dowód.

C. A, dowód? To wszystko niby takie państwowe, kultura i orzełek, a dowód ode mnie chcą, jakbym coś zrobiła. To wam powiem, że u nas na warzywniaku kultura jest większa. Nigdy mnie o dowód nie prosili, nawet jak im raz kalarepę zwinęłam. No dobra, macie. Ale kogo ja mam tu wybierać?

B. No to już Pani wybór, są różne partie...

C. Ale mówią, że rządzą nami Żydzi i Niemcy. No to ja już wolę na tych Niemców.

A. A co ma Pani przeciw $\dot{Z}$ ydom?

C. No sama nie wiem. Ale... Już wiem. Do kościoła nie chodzą. 


\section{Skecz 2. Wywiad z Postem}

Wchodzi pozdrawiają „piwnym gestem” spostrzega się, drugq ręka rozdziela palce $w$ literę $V$.

A. Spóźnił się Pan, Panie pośle. No, ale szczęśliwie Pan dotarł. Przedstawiamy Państwu posła stronnictwa Naród Wprzód.

B. Taki kurczę tłok na drodze.

A. Ale w takiej sytuacji ludzie przesiadają się na rowery.

B. Nie lubię pedałowania.

A. Co pan lubi najbardziej?

B. Najbardziej polską ziemię. Z dopłatami unijnymi oczywiście.

A. A co by Pan najpierw w Polsce zmienił?

B. Rząd.

A. Na jaki?

B. Narodowy. Oczywiście. Plus PSL, bo podobno bez niego się nie daje.

A. A jak już podzielicie te stanowiska, to co dalej?

B. Będziemy dzielić następne. Ostatnio nasi bardzo się starali, ale nawet do listonoszy nie doszli i skończyła się kadencja. Wystąpimy o jej przedłużenie.

A. A w stosunkach międzynarodowych?

B. Poszerzyć Alaskę o Syberię, aż do granicy z Wielkim Księstwem Litewskim.

A. A na Zachodzie?

B. Na Zachodzie bez zmian. To znaczy bez zmian dotacji na rejony przygraniczne. 


\section{Skecz 3}

A. Proszę Państwa. Przychodzi baba do lekarza, przepraszam, przychodzi baba do Dziekana. Nie, to już było. Proszę Państwa. Przychodzi Minister do ABW.

B. Dzień dobry. Przyszedłem się wyspowiadać.

A. A kiedy to się ostatnio było u spowiedzi?

B. No, cztery miesiące. Ale dowiedziałem się, że kolega mnie nagrywał, to pomyślałem, że już wszystko wiecie...

A. My i tak wszystko wiemy, ale przecież Pan wie, że pierwszym obowiązkiem ministra jest...

B. Wiem, wiem.

A. No to co jeszcze ma Pan nam do powiedzenia?

B. Widziałem jak Niesiołowski podglądał Muchę.

A. Eee, on ma taką profesję.

B. Ale to chodziło o posłankę Muchę.

A. Dobra już. W ogóle to w porządku gość, że mucha nie siada.

B. Kiedy on właśnie, jak ona siadała...

A. Dajmy temu spokój, co jeszcze?

B. Zgubilem pieczątkę.

A. No to numer. Niech Pan to dokładnie opisze.

B. To przez tą Merkel. Ona ma taki (pokazuje, że chodzi o biust) jak mi tym potrąciła, to mi tam wpadła. No co, miałem wyciągać?

A. Ech, nic poświęcenia dla kraju. Ale od biustów mamy specjalistę. Tomek... Tomek!

Zjawia się gość z perukq z dlugimi wlosami. 

A. Jest biust do roboty.
C. Ku chwale ojczyzny.

Skecz 4

Mim wygłasza przemówienie wyborcze z tłumaczeniem.

\section{Reklama 1}

B. Proszę Państwa, tego jeszcze nie było, uniwersalny środek usuwania plam na wyciągu z żyta.

Przychodzi A i C z butelka i kieliszkami.

C. Widzisz, jakie mi wyszty plamy.

A. Widzę, no to po małym (nalewaja, wychylaja).

C. Bo to wszystko przez nich (nalewaja, wychylaja). Do córki przyjeżdżał taki jeden. No i zrobili autostradę (nalewaja, wychylaja).

A. To dobrze.

C. Co dobrze? Zrobili (nalewaja, wychylaja) między jego, a naszą chałupą. To powiedział, że jak ma do panny jeździć przez Wrocław, to weźmie sobie ruską (nalewajq, wychylajq). Sama przyjdzie nawet w syberyjskie mrozy (nalewaja, wychylaja). A ja już placków napiekłam, i od tego oleju mam te plamy. Widzisz?

A. (betkotliwie) Nic nie widzę.

B. (podnosi tryumfalnie butelkę) Widzicie Państwo, nawet ta ilość wyciągu z żyta wystarczy, żeby plamy znikły. 


\section{Reklama 2}

A i B ogladaja kolorowe pismo.

A. Zostaw tego Playboya, to dla dzieci.

B. No dobrze, masz Hustlera.

A. $\mathrm{O}$ widzisz, cholera, ale mi się podnosi.

B. Wiesz, że mi też idzie do góry. No nie myślałem, że aż tak.

C. Proszę Państwa, właśnie koledzy wyczytali o podniesieniu oprocentowania depozytów w Banku Narodowym Aktiengesellschaft.

\section{List od Ojca Dyrektora}

Ktoś wpada i przynosi go $w$ ostatniej chwili.

A. Szanowne Koleżanki i Koledzy!

$\mathrm{Z}$ osobistego podsłuchu dowiaduję się, że twórczość naszego Wydziału została wykorzystana do celów politycznych, czemu zawsze byłem przeciwny, szczególnie, gdy, przejściowo, polityką się nie zajmowałem, a jeszcze bardziej, kiedy działo się to poza mną. W związku z tym chciałem poinformować, że z tym wszystkim, z czym mieliście (mam nadzieję - niechętnie) do czynienia, ja nie mam nic wspólnego. $Z$ wyjątkiem oczywiście honorarium (podany nr konta, banku, PESEL)

Ale gdyby Dziekan (nie")pozwolit, to oczywiście jestem za(przeciw*)

B. Ty, o co mu chodzi?

A. A kto tam go wie? Ale jest takie klasyczne twierdzenie w teorii zarządzania: dyrekcja ma zawsze racje, nawet jak nie wie, o co jej chodzi.

B. Który klasyk to powiedział?

A. Jak możesz nie wiedzieć - Ojciec Dyrektor.

* Odpowiednie skreślić. 


\section{Kabaret 2016 rok}

\section{Wprowadzenie}

Przed Wydziatem stoi wielka walka o punkty, konieczne do otrzymania godziwej kategorii naukowej. Potrzebne jest więc rozbudzenie ducha wspótzawodnictwa. Początkowo planowaliśmy zorganizowanie konkursu na największego uczonego, ale go i tak wygra prof. Wierzbiński. Inni, $\dot{z}$ eby nie wiem, ile jedli odżywek, to tak wyżej niego nie podskoczq. Sam się starałem, ale jakoś poszto wszerz, a nie wzdtuż. Inni też taki wynik moga powtórzyć, a ławki u nas ciasne. W zwiazku z tym postanowiliśmy zorganizować konkurs Miss Wydziatu. Jak się nie podporządkuja, to niech przychodzq na RW z wlasnq kawq i dtugopisem. A tak może datoby sie jakiś grant uzyskać?

Głos z Sali. Ja mam pomysł na lepszy grant! (podchodzi) Miałem okazję rozmawiać z kosmitą. Umówiłem się z nim na następny raz, ale powiedział, że tym razem pół litra to ja przynoszę. W dodatku wtedy piliśmy pod Drogę Mleczną, a mnie po nabiale mdli. To musiałbym też i sensowną zagrychę przynieść.

Ale czy przekazal jakieś ważne dla nauki informacje? 
Głos z Sali. Oczywiście że tak! Zapytałem, czy u nich wszystkie takie małe? Wszystkie. A czy wszystkie takie zielone? Wszystkie. A czy wszystkie mają takie nosy? Nie, tylko ci z Platformy.

No nie wiem, czy to tak wypada? No, ale przeciez od roku demokracja nam się rozwinęła i ludziom nie można zamykać ust. Ekssperymentalnie można zaprosić do Jury. Niech reprezentuje szeroka gamę pogladów. W końcu przeszli swoje za poprzedniego rzadu.

Babcia (...) A ja też przeszłam swoje za poprzednich rządów.

Co Pani robita?

Babcia. Pomagałam żołnierzom wyklętym.

Wspaniale. A z jakiej formacji?

Babcia. Ja nie wiem, to dawno było. W telefonie też tego nie mam, pewnie wnuczki wykasowały.

Ale może coś mówili?

Babcia. No tak jakby danke schön.

No, to może być problem.

Babcia. Ale na pewno nie „spasiba”. No nie. Co to, to nie.

To nie będziemy zajmować się szczegótami. To pewnie byli Holendrzy. Kombatantów nie możemy nie przyjać. Zapraszamy do Jury.

No właśnie dostałem pismo z protestem. Cała nasza katedra protestuje przeciw zastosowanemu wyborowi kandydatek. Jest u nas wiele urodziwych, ale żadna z nich nie dostała nawet propozycji.

Podpis nieczytelny, ale już wiem, o kogo chodzi. Szanowni Państwo, nie przesadzam. Niewatpliwie sq u was urodziwe kandydatki. Szkoda tylko, że tego po nich nie widać. 
Trzeci głos (...) Ja też chciałbym być w jury!

Dlaczego?

Jestem z ABW.

A to my do tej pory nie mieliśmy takiego? Myślatem...

My i tak wiemy, co Pan myśli. Inni też. Tu chodzi o to, by pod wpływem obcej propagandy wybór nie był niezgodny z interesem prawdziwych Polaków.

A jak poznać ten interes?

Jak to jak? Prezes pokaże.

No to trzeba się będzie mocno schylić..., och. Ale co ja mówię (to się wytnie), oczywiście zapraszamy. Ale czy mógtby się Pan z nami podzielić swoimi osiagnięciami, ciekawszymi doświadczeniami. Jeśli nie sq tajne?

No w gronie prawdziwych patriotów (jak Pan Dziekan mnie zapewnił) można być trochę swobodniejszym. Ja odzyskałem z rąk niemieckich wielkie dobro narodowe.

Ooo...!

To było jeszcze za czasów tamtego rządu, który...

To już wiadomo, prowadzit nas na skraj przepaści, a teraz Premier Morawiecki pozwoli naszej gospodarce zrobić wielli skok naprzód.

Tak dokładnie. W czasie podpisywania kolejnego traktatu z Niemcami, który miał nam odebrać...

Co miat odebrać?

Nieważne, bo nie doszedł do skutku. Ten urzędnik z kancelarï tamtego premiera miał przystawić pieczątkę, ale wziął za duży zamach i zawadził o coś wystającego.

Co konkretnie? 
Wie Pan, ta Angela ma trochę z przodu tego no... (stosowny ruch ręka). No i pieczątka wypadta?

Gorzej wpadła właśnie tam. Ale na szczęście wypadła, jak się Angela pochyliła nad uchodźcami, to wypadła z powrotem i udało mi się ją złapać. Potem w Toruniu odprawiło się krótkie egzorcyzmy i ten symbol narodowy jest uratowany.

Brawo, brawo i jeszcze raz brawo!

Wspaniała wiadomość. To teraz, jak to w każdej przyzwoitej telewizji publicznej. Czas na reklamę.

Przychodzi dwóch z butelka i kieliszkami.

A. Widzisz, jakie mi wyszły plamy.

B. Widzę, no to po małym (nalewaja, wychylaja).

A. Bo to wszystko przez tych z Unii (nalewaja, wychylaja). Do syna przyjeżdżał taki jeden, narzekał, że przez te nasze drogi biust mu się trzęsie.

B. Biust u faceta?

A. No. Tam teraz są tylko takie. No i zrobili autostradę (nalewaja, wychylaja).

B. To dobrze.

A. Co dobrze? Teraz mi cała chałupa się trzęsie, a jak robię placki to mi ten olej pryska. Widzisz?

B. (betkotliwie) Nic nie widzę.

C. (podnosi tryumfalnie butelkę) Widzicie Państwo, nawet ta ilość wyciągu z żyta wystarczy, żeby plamy przestały być widoczne. 
(czytanie $z$ kartki) Protestuję przeciw zastosowanemu trybowi wyłaniania kandydatek. Nie zostaliśmy uprzedzeni, ale przecież u nas są też urodziwe.

No może i tak, urodziwe, szkoda tylko, że tego po nich nie widać. Nie uwzględniamy. Jak chca, niech pisza do Trybunatu. I tak jego opinii nie opublikuja. Jury jest suwerenne. Nie ma co, przechodzimy do finatu.

Finał. Oto kandydatki (ktoś przynosi plastikowe misy), każda z nich (ponumerowane) przechodzi oddzielnie.

Każdy z jurorów opisuje własną kandydatkę (teksty przykładowe):

- (głaszcząc, rozanielony od spodu) Ta gładkość, kształtność, te krągłości...

- Dokonując wyboru tej z przedstawionych miss żaden Polak nie będzie się musiał wstydzić, wysuwając rękę z nią po dolary lub euro.

- Patrząc na tę wybraną, chciałbym, żeby była pełna moich uczuć, względnie biletów Narodowego Banku Polskiego.

- No to już zależy od katedry. Psycholodzy niech zajmą się uczuciami. My finansiści zajmiemy się tymi biletami.

Jurorzy nie mogą się dogadać. W tej sytuacji odwołujemy się do narodu. Publiczność dokonuje wyboru brawami. Następuje ogłoszenie laureatki Konkursu Miss na Wydziale Zarządzania.

Dziekan bierze laureatkę na kolana. Brawo! 